\title{
Projeto do \\ Codigo Criminal \\ Brasileiro
}




\title{
I N D I C E
}

Exposição de motivos do ante-projeto na Parte Geral

\section{PRO.JETO DO CODIGO CRIMINAL}

\author{
LIVRO I
}

\section{PARTE GERAL}

Titulo I

Da aplicação da lei criminal

Titulo II

Do crime

Truwo II

TITULO III

Do agente

CAP. I - Da imputabilidade $\ldots \ldots \ldots \ldots \ldots \ldots \ldots \ldots \ldots \ldots .234$

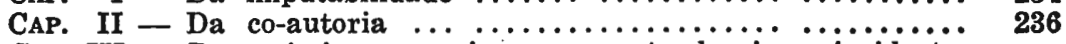

CAP. III - Dos criminosos racionaes, por tendencia, reincidentes

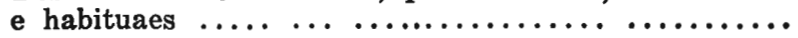

\section{TITULO IV}

Das penas

CAP. I - Das varias especies de pena $\ldots \ldots \ldots \ldots \ldots \ldots . \ldots 241$

Secção $I$ - Da pena de morte $\ldots \ldots \ldots .242$

Seção II - Das penas privativas da liberdade 243

Secção III - Da pena de multa $\quad . . \ldots \ldots .249$

CAP. II $-\mathrm{Da}$ aplicação da pena $\ldots \ldots \ldots \ldots \ldots . \ldots \ldots 2$

CAP. III - Dos efeitos da condenação $\ldots \ldots \ldots \ldots . \ldots \ldots \ldots .259$

Secção $I$ - Do registro da sentença...... 260

Seçãao II - Da confiscação . . . . . . . 261

Secção III - Da publicação da sentença ..... 262

Secção IV - Da inhabilitação .. ........ 263

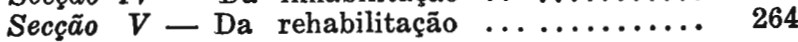

CAP. IV - Da condenação de execução condicional e do livra-

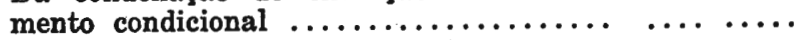

Secção I - Da condenação de execução condicional ................. 268

Seção $I I$ - Do livramento condicional ....... 271 
Titulo V

Das medidas de segurança

CAP. I - Das medidas de segurança em geral. . ....... 274

TAP. II - Das medidas de segurança em especie $\ldots \ldots \ldots \ldots .280$

\begin{tabular}{|c|c|}
\hline Secção & 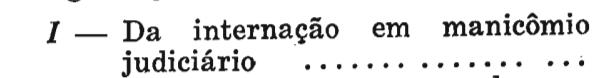 \\
\hline Secção & $\begin{array}{r}I I \text { - } \mathrm{Da} \text { internação em casa de cus- } \\
\text { tódia e tratamento . ......... }\end{array}$ \\
\hline Seç̧̃̃o & $\begin{array}{l}I I I \text { - Da internação em instituto de } \\
\text { trabalho obrigatorio } \\
.\end{array}$ \\
\hline Seç̧ão & $I V$ - Da liberdade vigiada .. \\
\hline Secção & $V$ - Do exilio local $\ldots \ldots \ldots \ldots$ \\
\hline $\operatorname{Seç̧\tilde {a}o}$ & $\begin{array}{l}\text { - Da proibição de frequentar de- } \\
\text { terminados logares } \ldots \ldots \ldots \ldots \ldots\end{array}$ \\
\hline $\begin{array}{l}\text { Secção } \\
\text { Seç̧ão }\end{array}$ & $\begin{array}{l}\text { - Da expulsão do estrangeiro ... } \\
\text { - Da caução de bom comporta- }\end{array}$ \\
\hline ecção & $I X$ - Da clausura do estabelecimento \\
\hline
\end{tabular}

TITULO VI

Do regime da minoridade

CAP. I — Dos menores de 18 anos ............... 293

CAP. 11 - Dos maiores de 18 e menores de 21 anos $\ldots . . . .297$

TITULO VII

Da ação criminal

$\ldots \ldots, \quad \ldots \ldots, \quad \ldots, \quad \ldots$

\section{LIVRO II}

\section{PARTE ESPECIAL}

\section{Titulo I}

Dos crimes contra a personalidade do Estado

OAP. I - Dos crimes contra a Nação Brasileira $\quad \ldots \quad \ldots \quad \ldots \quad \mathbf{3 1 0}$

CAP. II - Dos crimes contra Estados estrangeiros $\ldots \ldots \ldots \ldots .318$

CAP. III - Dos crimes contra os direitos políticos do cidadão. $\quad 319$

CAP. IV — Disposições comuns $\ldots \ldots \ldots \ldots \ldots \ldots \ldots \ldots \ldots \ldots$

\section{Titulo II}

Dos crimes contra a administração pública

CAP. I - Dos crimes praticados por funcionarios contra a ad-

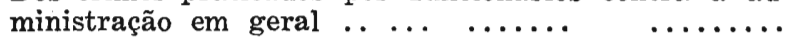

CAP. II - Dos crimes praticados por particulares contra a ad-

CAP. III - Dos crimes contra a administração da Justiça $\ldots \ldots$ 
TITULO III

Dos crimes contra a ordem e a tranquilidade públicas

CAP. I - Dos crimes referentes a ordem pública $\ldots \ldots \ldots . \quad 348$

CAP. II — Dos crimes referentes á tranquilidade pública .. . . 352

Título IV

Dos crimes contra a economia nacional

CAP. I - Dos crimes referentes á economia pública em geral.. 355

CAP. II - Dos crimes referentes ao trabalho ........... 357

CAP. III - Dos crimes referentes á agricultura, indústria e comércio .. $\ldots \ldots \ldots$...............

\section{Titulo V}

Dos crimes contra a incolumidade pública

CAP. I - Dos crimes referentes á saúde pública $\ldots \ldots \ldots \ldots$ 366

CAP. II - Dos crimes referentes á segurança dos meios de comunicação e transporte e outros serviços públicos...

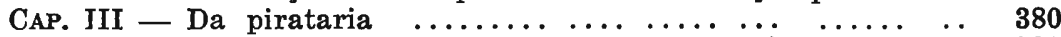

CAP. IV - Do incendio e de outros crimes de perigo comum. 382

\section{Titulo VI}

Dos crimes contra a fé pública

CAP. I $\quad$ Dos crimes referentes á moeda $\ldots \ldots \ldots \ldots$

CAP. II - Dos crimes referentes a titulos e papeis de emissão

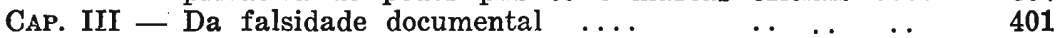

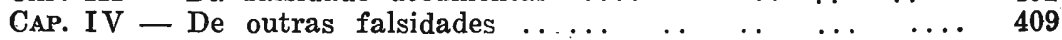

Titulo VII

Dos crimes contra o sentimento religioso e o respeito aos mortos

CAP. I - Dos crimes referentes ao exercicio dos cultos ... 410

CAP. II - Dos crimes contra o respeito devido aos mortos ... 4.11

\section{TITULO VIII}

Dos crimes contra o pudor individual e a moralidade pública

CAP. I - Dos crimes referentes a liberdade sexual $\ldots \ldots \ldots 413$

CAP. II — Dos crimes de corrupção ... ..... ....... 417

CAP. III - Disposições comuns aos dois capitulos precedentes. 419

CAP. IV - Do ultraje público ao pudor $\ldots \begin{array}{lllll} & \ldots & \ldots & \ldots & 423\end{array}$

TITUlo IX

Dos crimes contra a familia

月. I - Dos crimes referentes ao casamento ........... 424

II - Dos crimes referentes ao estado de familia ... . . . 426 
CAP. III - Dos crimes referentes á moralidade da familia ...

CAP. IV - Do abandono moral e material da familia ........

CAP. V - Dos crimes contra a autoridade dos titulares do patrio poder, tutela e curatela .............

\section{Trtulo $\mathrm{X}$}

\section{Dos crimes contra a pessôa}

CAP. I - Dos crimes contra a incolumidade pessoal ...... 432

Seç̧ão $I$ - Dos crimes contra a vida ..... 432

Secção $I I$ - Das lesões ... ........... 437

Seç̧ão $I I I$ - Da rixa ............... 440

Secção $I V$ - Da periclitação da vida e da saude 440

CAP. II - Dos crimes contra a honra ... .......... 445

CAP. III - Dos crimes contra a liberdade individual ....... 451

Secção $I$ - Dos crimes referentes á liberdade pessoal .................. 451

Secção II - Dos crimes contra a inviolabilidade do domicilio ................

Seçãa $I I I$ - Dos crimes contra a inviolabilidade da correspondencia ........... 457

Secção IV - Dos crimes contra a inviolabilidade dos segredos ..............

\section{TITULO XI}

\section{Dos crimes contra a propriedade imaterial}

CAP. I - Dos crimes referentes á propriedade literaria, cien-

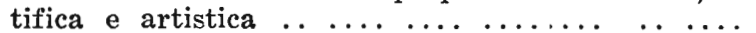

CAP. II - Dos crimes referentes ás patentes de invenções..

CAP. III - Dos crimes referentes ás marcas de industria e co-

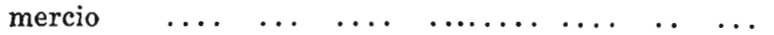

Título XII

Dos crimes contra o patrimonio

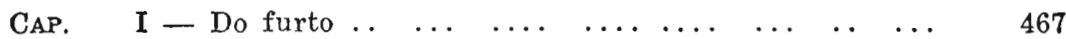

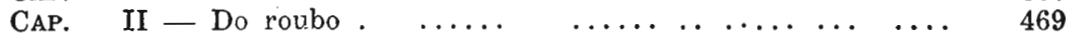

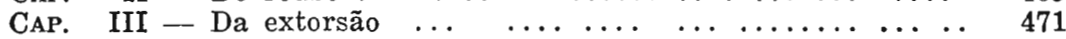

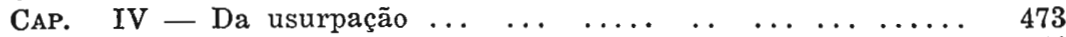

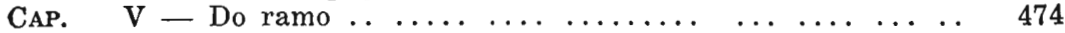

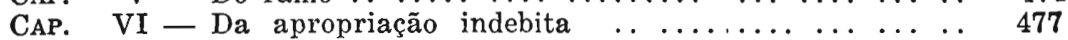

CAP. VII - Do estelionato, do abuso de confiança e outras fraudes $\ldots \ldots \ldots \ldots \ldots \ldots \ldots . . . \ldots \ldots \ldots$

CAP. VIII — Da falencia e da fraude á execução $\ldots . . . \quad \ldots . .485$

CAP. IX - Da receptação e outros crimes afins com os patrimoniais ...................... 486

CAP. $\quad \mathrm{X}-\mathrm{Da}$ periclitação do patrimonio ............. 488

CAP. XI - Disposição comum $\ldots \ldots \ldots \ldots \ldots \ldots \ldots \ldots . \ldots \ldots . \ldots . \ldots 4$

Disposiçóes finaes $\ldots \ldots \ldots \ldots \ldots \ldots \ldots \ldots \ldots \ldots \ldots, 493$ 


\title{
Exposição de Motivos do Ante-Projeto da Parte Geral do Código Criminal Brasileiro
}

\author{
Alcantara Machado
}

(Organizado por incumbência do professor dr. Francisco Campos. Ministro da Justiça).

Tutto il Codice Penale, in funzione del regime politico, dal quale deriva, $\dot{e}$, come reazione a precedenti eccessi di indulgenza - riverbero anch'esso di conformi condizioni sociali - intonato a severità coll'obbietto di difendere lo Stato da quelle forze dissolvitrici che sono assai diffuse e profonde nel mondo moderno, per la sua struttura, per il numero di coloro che partecipano consapevolmente alla vita pubblica, e per la complessità degli interessi che si contendono in campo... Tale constatazione non conduce, tuttavia, alla conclusione - che. sarebbe catastrofica - di una grossolana trascuratezza dei diritti dei singoli a vantaggio di uno Stato astratto -- non inimaginabile ormai - in urto col bene e colla libertà dei cittadini.

\section{Adolfo Zerboglio}

(in Scritti teorico-pratici sulla nuova leg?lazione penale italiana, 22, p. 87). 
EXMO. SR. MINISTRO DA JUSTIGA

Honrado por V. Exa., em fins do ano transato, com a incumbencia de estudar a reforma de nossa legislação penal, pensei a principio que só me restaria levar a termo a revisão, já iniciada pela Comissão de Justiça do extinto Senado, do projeto elaborado pela Comissão Legislativa, de que fizeram parte os ilustres juristas patricios Virgilio de Sá Pereira, Bulhões Pedreira e Evaristo de Moraes.

Verifiquei, porém, desde logo, serem de irrecusavel procedência as criticas que êsse trabalho vinha despertando e continua a provocar em o nossso meio jurídico, unânime em proclamar a competência inexcedivel dos operários, mas acórde em reconhecer as imperfeições da obra. Bem expressivos são os pareceres, em que os notaveis professores NoÉ AzEvedo $e$ Correia de ARAujo manifestam o juizo desfavoravel das Congregações das Faculdades de Direito de S. Paulo e do Recife, quando ouvidas a respeito. Não menos significativo o pronunciamento contrário de todas as nossas autoridades, nas obras de direito criminal publicadas ultimamente. Assim, por exemplo, Costa e Silva, em seu eruditíssimo comentario ao código penal em vigor, onde a Parte Geral do projeto é alvo de repetidas censuras; ataliba Nogueira, que desnudou, em tese de concurso, as deficiencias do trabalho em apreço, no que respeita ao problema fundamental das medidas de segurança; Basileu Garcia, que, em monografia recentissima, apontou a maneira defeituosa, por que se pretendeu resolver o problema da repressão ao homicidio; Percival de OLIveIra, que, em trabalho agora publicado, indicou a lacuna imperdoavel do projeto revisto, no que toca ao delito de abandono da familia; JoRGE Severiano, que ainda ha poucos dias denunciou, pelas colunas do "Correio da Manhã" o perigo social que representa a outorga, consagrada no projeto, do "sursis" aos chamados criminosos passionais. $\mathrm{Na}$ propria Conferencia aqui realizada o projeto não saiu incólume dos debates, sem embargo da defesa inteligente com que procuraram ampará-lo dois de seus preclaros colaboradores. Dêle divergiu a Conferencia em pontos substanciais, como sejam a definição de culpa, o princípio de causalidade, a fórmula da inimputabilidade por alienação mental ou estados análogos... 
De fato, o projeto nâo podia servir de base á reforma projetada. Deixo de parte a redaçẫo de um sem número de dispositivos, a que faltam a clareza, a simplicidade, a transparência consubstanciais á linguagem legislativa. Averba-a de descuidada o mais profundo comentador de nossa legislação penal (Costa E Silva, Cod. Pen., p. IV. nota 1). E tem razão. Tome-se ao acaso um dispositivo. Seja o art. 23. Ai começa por declarar que "todo aquêle que cometer crime será obrigado a reparar o dano, salvo quando a criminalidade do ato fôr excluida", isto é, quando o`ato não constituir crime. A seguir vem o $§ 1$, que se alonga, em sua parte inicial, da verdade juridica, e em sua última parte desafia a argúcia dos decifradores: "A obrigação do inimputavel (em materia de reparação do dano) é condicionada pela sua capacidade econômica, preferentemente atendida a situação especial em que a inimputabilidade o tiver colocado". Outras vezes o projeto deixa transparecer uma excessiva preocupaçâo literária, que o torna de dificil compreensão para o vulgo. E' o caso do art. 101, em que o criminoso tem a pena atenuada, quando "crise moral profunda ou, sem culpa sua, situação angustiosa o empolgava". Esses e outros deslises evidenciam que nâo sobrou aos eminentes autores o vagar necessário para o desbaste e o polimento, de que seriam capazes.

Não insistirei nas falhas, que se notam na distribuição das materias. O novo Codigo italiano não constitue, nêste particular, como tambem no que diz respeito á redação, modêlo aconselhavel.. Porque regular a açâo penal no capitulo que se refere ao crime? Porque consagrar todo um capitulo ao ofendido, quando ai se trata apenas da iniciativa da ação penal, o que torna evidente que na parte referente a esta última se incluiria melhor a materia? $E$ como enquadrar a violação do segredo profissional do médico, do advogado, do confessor entre os crimes contra a inviolabilidade e a segurança da correspondencia, a remoção de marcos divisorios entre os crimes de falsidade em documentos públicos ou privados, o fato de alguem fingir-se funcionario público sob a rubrica de "trajes indevidos"?

Passarei de ligeiro sôbre as objeções de ordem doutrinaria, que o projeto suscita. Abre-se no art. 33, em favor do inimputavel, uma exceção desarrazoada ao princípio universal da indivisibilidade e solidariedade entre os partícipes, em materia de reparação do dano causado por ato ilícito. Entrega-se ao júri, no art. 108, a classificação do réo entre os criminosos por indole. Determina-se no art. 160 que não exceda de dois anos a duração das medidas detentivas de segurança aplicaveis aos criminosos de imputabilidade restrita, o que é tudo quanto ha de mais contrário aos objetivos de medidas dessa natureza. E, para apontar apenas um só dos muitos defeitos 
da Parte Especial, não se alude na definição de infanticidio (art. 168) á "causa honoris", que, na melhor doutrina, é uma das condições existenciais daquela figura delituosa.

Não me alongarei em anotar as lacunas que oferece o projeto. Duas amostras. Primeira: ninguem saberá quais as medidas de segurança a que ficam sujeitos os selvicolas inimputaveis ou de imputabilidade restrita. Segunda: repudiando sem nenhuma razâo o projeto primitivo de SA Pereira, a Comissão Legislativa suprimiu, dentre os fatos puniveis, o abandono de familia.

Dispensar-me-ei de mostrar os vicios de classificação. O crime de omissão de socôrro, vamos encontrá-lo inexplicavelmente entre as contravenções. A publicação da sentença figura entre as penas acessorias; o que não impede que se publique a sentença á custa do Estado, do denunciante, do querelante, no caso de absolvição. Sob a rubrica de penas acessorias estão a expulsão do estrangeiro e o exilio local, que as legislações contemporaneas incluem entre as medidas de segurança. E assim por diante.

Tudo isso, com maior ou menor trabalho, podia ser' objeto de correção ou emenda. Outros defeitos; porém, apresenta o notavel trabalho, que tornam impossivel tomá-lo como fulcro da reforma de nossa legislação penal, porque entendem com a orientaçâo, as idéas dominantes, o espirito do projeto.

Redigiu-o a Comissão Legislativa (e não podia deixar de fazê-lo) acordemente com as condições' politicas e sociais do tempo. Umas e outras se modificaram profundamente de então para hoje. Os movimentos subversivos de 1935 patentearam a gravidade e a extensâo dos perigos a que nos expunha a deficiencia do nosso aparelhamento repressivo. A Constituiçẫo de 10 de novembro deu nova estrutura ao Estado e novo sentido á politica nacional, tornando imperiosa a mudança das diretrizes penais. Reforçar a defesa coletiva contra a criminalidade comum e resguardar as instituições contra a criminalidade política, são imperativos a que nâo pode fugir o'legislador em paizes organizados da maneira por que atualmente se encontra o nosso.

Ora, o projeto da Comissão Legislativa não podia antecipar-se ao futuro. Dat a sua incompatibilidade com as realidades do presente.

A simples colocação dos crimes a Nação e a organização social e política, depois dos crimes contra a vida, a saúde e a integridade corporea, o patrimonio, a liberdade pessoal, os bons costumes, etc., denuncía a concepção reinante ao tempo da elaboraçâo do trabalho em apreço. As penas cominadas contra criminosos daquela calkgoria são simplesmente ridiculas. Punem-se com prisâo até 3 
anos a provocação á desobediencia militar (art. 391), a conspiração (art. 378), e até a cspionagem militar em tempo de guerra (art. 389).. Não é preciso dizer mais.

Se no tocante á criminalidade politico-social o projeto se revela dessa benignidade incrivel, não menor é a sua complacencia para com os criminosos comuns. Pululam os exemplos. Vejam-se o art. 120, que, no caso de condenação por homicidio passional, permite a susperisão da execução da pena. o art. 57 que, proibindo a conversão da pena pecuniaria em detentiva, torna completamente ilusoria a pena de multa.. o art. 63, que atribue ao condenado á detenção a faculdade "de fazer vir de fóra a alimentação (1), excluidas as bebidas alcoolicas" e a de "escolher dentre os (trabalhos) que se executarem no estabelecimento, o que melhor lhe convenha (!), se não preferir trabalhos intelectuais, a que já esteja afeito" $O$ médico e o advogado dariam consultas, o enyenheiro abriria estradas, o professor aceitaria alunos, o poeta comporia poemas, e romances o romancista.

Basta o que deixo dito sucintamente, para justificar a deliberação, que tomei, de não me circunscrever a uma simples revisão du projeto, e sim de fazer obra diferente na substancia e na estrutura.

O que desde já venho submeter apreciação de V. Exa. é a Parte Geral do futuro Codigo Criminal Brasileiro, tal qual me parece consultar á verdade jurídica e ás condiçôes do meio em que tem de atuar. Um código dessa natureza (assinala Pozzolini) não pode ser obra puramente científica: ha uma relação lógica e necessária entre o seu conteúdo e as circunstancias políticas e sociais do logar e do momento. Se V. Ex. estiver de acordo com os principios dominantes da reforma, prosseguirei na articulação da Parte Especial, iniciada ao tempo em que presidi os trabalhos da Comissão de Justiça do Senado.

1. - Código Criminal ou, mais exatamente, Código Criminal Comum, e não Código Penal. Porque, antes de tudo, o Código não se ocupa sómente de penas, mas tambem de medidas de segurança que não têm carater punitivo; e, consoante a observação justíssima de Grovanovitch (em Il Codice Rocco e le recenti codificazioni penali, $I I, p .40)$, a denominação "código penal" estará em contradição com o conteúdo, toda a vez que as medidas de segurança ocuparem no texto legislativo logar de importancia igual ao das penas. $\boldsymbol{E}_{\text {, }}$ ainda, porque a codificação projetarla se refere apends atotireito 
penal comum; de sorte que dela se excluem as disposições penais constantes das legislações financeira, administrativa, industrial, e do direito penal militar, do direito penal mercantil, do direito penal maritimo. Como poderemos dar o nome de penal a um código, em que, na frase de Florian (Trattato, I, 1934, n. 116), "non tutto il diritto penale è raccolto"?

\section{2. - O ante-projeto não trata das contravenções.}

Excusado seria encarecer as dificuldades, com que se debatem os doutores e os legisladores, na pesquisa de um criterio diferencial entre contravenções e crimes. $E^{\prime}$ de 1937 a obra de SABatini. (Delle contravvenzioni in particolare), em que depois de analisar todas as distinções aventadas na doutrina, elle assim conclue: "Si $\dot{e}$ visto che tutte le dottrine intese a dare una soluzione al tormentoso problema, nella inquieta ricerca di un elemento specifico nettamente diferenziale, di ordine obiettivo o subiettivo, non resolvono nulla, dimostrando che solo il legislatore deve in concreto precisare se un fato sia contravvenzionale o delituoso; giacchè la natura di esso non puó assolutamente dipendere da criteri asttrati e ontologici, ma dal modo come lo stesso legislatore formula gli elementi del reato e della finalità che egli intende raggiungere nel determinare il contenuto e la corrispondente sanzione ad esso applicabile" E' tambem dos últimos dias do ano passado o livro de Cosentrini, Code Pénal International. $O$ que a doutrina não descobriu, os legisladores não encontraram até agora: "Pour ce qui concerne les contraventions, l'analyse comparée nous a procuré les surprises les plus étonnantes. Nous avons dû constater qu'on a classé, avec une extrême désinvolture, parmi les contraventions... des infractions que d'autres Codes considèrent comme des délits et même comme des crimes véritables, et que certains Codes caractérisent comme contraventions ce que d'autres considèrent comme délits. C'est là une erreur commune à presque tous les projets et textes de codes pénaux que nous avons examinés. Les exemples peuvent être multipliés à l'infini"

A diferença está sómente, de acordo com o código italiano e com Sabatini, na quantidade da pena. Tudo quanto ha de mais empirico.

Melhor será incluir as chamadas contravenções geraes entre os crimes, deixando as outras, as simples infrações de policia, para a legislação administrativa da União, dos Estados e dos Municipios. Na Argentina a materia de "faltas" é de competencia provincial. O último projeto austríaco deixou igualmente de lado as contravenções. "Atentas as condiçôes especiaes do paiz" os autores do novo código penal columbiano, de 24 de maio de 36 , resolveram que o assunto tôsse regulado em lei geral de policia, sem prejuizo das infrações da 
competencia local (Criminalia, México, n. de abril de 38, p. 491). Essa, a orientação que nos parece mais acertada.

3. - $O$ ante-projeto divide-se em dois livros. $O$ primeiro, já concluido, trata das disposições geraes. O segundo, em adiantada elaboração, dos crimes em especie.

Aquele está subdividido em 7 titulos, que se ocupam sucessivamente da aplicação da lei penal, no tempo e no espaço, do crime, do agente, da pena, das medidas de segurança, do regime da menoridade e da ação criminal. A materia de cada titulo se redistribue, conforme o caso, em capitulos, secções, subsecções. Essa, a trad:ção brasileira, de que o ante-projeto não se aparta.

4. - Objeto do titulo I é a aplicação da lei penal no tempo e no espaço.

Em mais de um ponto se distancia do direito vigente o anteprojeto.

Assim, resolve de modo terminante a questâo, que o Código de 90 e o projeto da Comissão Legislativa deixam em aberto, da eficacia das leis contingentes ou excepcionais, com que se acodem a exigencias imprevistas, extraordinarias, transitorias, e das leis temporarias, em que se prefixa a duração de sua vigencia. Em casos tais não caberá a aplicação da "lex mitior"; $e$ isso "perchè non sia diminuita la forza punitiva o repressiva di tali leggi con la previsione del ritorno alla legalitá" (MANziNi, Instituzioni, 1935, n. 20, p. 35).

Assim, corrige o equívoco do projeto da Comissão e do Código de 1890, que mandam aplicar a lei posterior, se fôr mais branda a pena por ela cominada. Não ha considerar sómente a penalidade. E' o que adverte Bataglini (Il progetto Rocco, I, p. 163): “Per determinare quale legge sia piú favorabile all'imputato, non basta confrontare ció que attiene alla pena, ma occorre por mente a tutto quanto puó dare un risultato favorabile al reo (condizioni dell'exercicio dell'azione penale, tempo della prescrizione, elementi necessari a constituire il reato, ecc.)"

Assim, admite em certos casos e para determinados efeitos, a autoridade da sentença estrangeira, o que representa mais um passo em favor da tese universalista, defendida desde muito por Francisco CARRARA $e$ inspirada no pensamento de que, ao reprimir o crime, o Estado funciona como órgão, seja de um principio de justiça, que lhe é anterior e superior, seja de um interesse vital da humanidade inteira. $O$ ante-projeto acompanha neste particular o Código italiano, cujas disposições foram elogiadas calorosamente por DoNNEDIEU dE VABres (em Il progetto Rocco, I, p. 207). E' este um dos pontos, diz êle, em que os autores do projeto foram de feliz originalidade. 
conseguindo, como conseguiram, a conciliação harmoniosa de duas ideas justas: de um lado, a impossibilidade de se atribuir efeito juridico no territorio de um Estado a julgamento pronunciado em outro, como manifestação de soberania estrangeira; e, de outro lado, a consideração de que tal julgamento é fato, que se deve ter em conta, não só para a proteção eficaz dos interesses da coletividade, como para a salvaguarda dos direitos individuaes.

Assim, finalmente, regula o ante-projeto o cômputo dos prazos em materia penal, de acordo, até certo ponto, com os principios consagrados na legislação civil.

5. - "Do crime" intitula-se o titulo II. Essa, de fato, a ordem lógica. Faço minhas as palavras dos autores do projeto argentino de 1937: "Nos ocupamos del delito antes que del delincuente, porque, apesar de ser este el protagonista del hecho sancionado por la ley, es tal hecho el que se apresenta de immediato, en su objetividad, a la consideración de la justicia penal y el que determina las actividades de la misma".

Excusado seria definir o crime, como fazem o cod. de 1890 e o projeto da Comissão Legislativa. Definem-se as varias modalidades do elemento subjetivo, isto $\dot{e}$, o dolo, a preterintencionalidade e a culpa. Note-se de passagem que a ausencia de disposição geral sobre a preterintencionalidade e a limitação desta última ao crime de homicidio foram inculpados, pelo voto quasi unânime da Conferencia Brasileira de Criminologia, ao projeto da Comissão Legislativa.

As noções, que de culpa, dolo e preterintencionalidade consigna o ante-projeto, são em substancia as mesmas do código italiano e do projeto argentino. Apesar de abonada por varios dentre os últimos códigos e projetos, a de culpa, que a Comissão Legislativa perfilhou, foi desaprovada pela Conferencia de Criminologia: - " $E$ ' extremamente lacunosa (acentuou NARCELIo DE QUEIROz em uma das conclusões de seu relatorio), pois só se refere, como elemento psicológico do delito culposo, á negligencia, omitindo qualquer alusão ḋ impru. dencia, á impericia e á desobediencia ás leis, regulamentos e ordens". Por esse fundamento, isto é, por não compreender a definição proposta a culpa com previsão, e tambem por não ser facilmente acessivel ao júri "a linguagem arrevezada do art. 27", a Conferencia adotou, por maioria consideravel, o substitutivo de Filadelfo Azevedo, assim redigido: "deve ser mantida quanto á culpa, a redaçâo do codigo vigente, excluida a parte final a respeito de arte ou profissão" E' o que faz o ante-projeto.

o dispositivo seguinte ocupa-se da relação de causalidade entre a ação e a omissão do agente, e o evento danoso ou perigoso. Ainda tate ponto acompanha o ante-projeto a orientação do código italia- 
no. Acompanhava-a igualmente o projeto da Comissão. Mas de modo a merecer a critica dos competentes. Aqui está o que escreve a respeito Basileu Garcia (Soluções penaes da repressão ao crime de morte, p. 189): -- E' uma sintese do dispositivo italiano, o qual, sendo mais extenso, é tambem mais claro. A causa independente da ação do infrator, suficiente por si mesma para produzir o resultado, só pode ser absolutamente independente, entendendo-se, pois, que as condições, mesmo independentes, que não o sejam absolutamente, não excluem o nexo de causalidade entre a ação e o acontecimento. Teria sido, porém, mais útil dize-lo categoricamente. "Sobrevindo causa" é quasi a tradução de "cause sopravvenute" restrição que Florian foi o primeiro a criticar, acompanhado desde logo por inumeros escritores que lhe deram o seu assentimento... o titulo "concausa" dá uma falsa idea do texto, que vem exatamente banir o instituto das concausas. " De censuras semelhantes procura fugir o ante-projeto. Atende, assim, á justissima observação de FloRIAN (Tratt. I. n. 511): não é apenas a causa superviniente que exclue o nexo de causalidade, se bastante por si só para determinar o evento; mas tambem a anterior e a simultânea, quando suficientes por si mesmas para a produçâo do resultado.

As definições, que vém a seguir, do crime consumado e do crime tentado, são, com leve diferença, as mesmas do projeto da Comissão que acertadamente se inspirou por sua vez no projeto Ferri.

Do trabalho da Comissão afasta-se, porém, o ante-projeto no tocante á penalidade da tentativa. Repugna á conciencia coletiva equiparar a tentativa ao crime consumado, para o efeito da repressão. $E^{\prime}$ o que, apesar de suas tendencias, reconhece o projeto argentino, ao mandar que a sanção não seja imposta no grau máximo ao autor da tentativa. E' o que confessa o projeto alemão, ao dispôr que a pena da tentativa seja mais branda.

6 - "Do agente" é a epigrafe do título imediato, onde se apresentam questões da maior delicadeza e gravidade.

O ante-projeto enumera os que não são passiveis de pena: os que conetem a ação ou omissão por caso fortuito ou força maior, por erro de fato excusavel, ou sob a pressão de ameaça ou de violencia; renuncia depois as causas que excluem a criminalidade da infraçâo; e como taes considera o consentimento do ofendido, em se tratando de bem ou interesse juridico, de que possa livremente dispôr, a obediencia a ordem emanada de superior hierárquico no exercicio de suas funções, a legitima defesa de direito proprio ou de terceiro, e o estado de necessidade. Não alude, como o projeto da comissão, o projeto argentirio e vários códigos, entre os quaes o peruano $e$ italiano, aos atos praticados no exercicio de um direito ou no cum- 
primento de dever legal, porque se trata de verdade intuitiva, que nunca foi objeto de dúvida. Não alude tambem ao caso da resistencia a ordens ilegaes, que as novas legislações não contemplam, por ser inteiramente supérflua a disposição.

o problema do excesso, resolve-o o ante-projeto de acordo corn a solução que Costa E Silva (p. 265, nota) qualifica de mais razoavel. Assinale-se que no caso nenhum motivo existe para aplicar-se a pena "de acordo com a periculosidade do agente", quando este seja reincidente ou por indole, como determina o art. 12 do projeto da Comissão. Não terão o reincidente e o criminoso por indole o direito de invocar a legitima defeza, o estado de necessidade, a obediencia $\dot{a}$ ordem legal da autoridade, a que estiverem subordinados? Porque, no caso de excesso, trata-los diferentemente das outras creaturas humanas?

Declara a seguir não passiveis de pena, e sim de medidás de segurança, os menores de 18 anos, os surdos-mudos sem educação, os selvicolas não adaptados ao meio social $e$ os alienados.

Discrimina, emfim, os que são passiveis de pena diminuida'e tambem de medidas de segurança: maiores de 18 anos'e menores de 21, surdos-mudos, selvicolas de adaptação incompleta e portadores de grave anomalia psíquica que não importe em alienação mental.

Assim, a sociedade se defenderá contra todos quantos infrinjam a lei penal: para os alienados o manicômio judiciario, onde permanecerão até que não mais se mostrem perigosos; para os deficientes $e$ anormaes a casa de tratamento e custodia, onde serão segregados $e$ tratados durante o cumprimento da pena diminuida; para os selvicolas, o instituto de trabalho obrigatorio que os adaptará ao ambiente civil; para os menores de 18 anos, a reeducação por uma série de medidas tutelares.

Não ha quem ignore as dificuldades com que se depara o legislador na definição da inimputabilidade penal de causa patológica. Tres os caminhos que se lhe abrem á frente: indicar um caso típico de desequilibrio mental, em que todos os outros se incluam por extensão ou por analogia, e é o que fazia o nosso código de 30, quando falava de "loucos de todo o genero", e faz o Codigo francês, ao falar de "demencia"; ou estabelecer um critério puramente psicológico, sem referencia precisa a qualquer estado mórbido, e tal a orientação do nosso codigo de 90 e do Código de Zurich; ou fundir em um só os lois processos ou métodos, e essa é a diretriz seguida pela grande maioria das legislações contemporaneas.

O primitivo projeto SÁ PereIRA disciplinava desta sorte a matefria: "carecem de imputabilidade os que se encontram em esatdo de 
alienação mental, idiotia ou inconciencia, ou restrita ela será nos que apenas tiverem diminuida a faculdade de normalmente determinar os proprios atos, embora por causa mórbida que daqueles estados se aproxime" Costa E Silva (I. p., 194, nota) tornou patente desde logo a incongruencia: "nesse arrevesado periodo a noçẫo da implttabilidade é estabelecida pelo método biológico e a da imputabilidade restrita pelo psicológico. Os métodos são imperfeitos e nada explica a desigualdade".

$\mathrm{Na}$ revisão do projeto primitivo triunfou o sistema ou processo mixto: "Carecem de imputabilidade aqueles que por doença mental, desenvolvimento mental incompleto ou retardado, perda ou grave alteração da conciencia, não possuirem a faculdade de normalmente determinar os proprios atos". Restrita será a imputabilidade (acrescenta o art. 19) "se esta faculdade, não estando abolida, estiver entretanto sensivelmente diminuida por alguma das causas acima especificadas". Assim redigido, o dispositivo foi averbado de infeliz por Nerio Rojas e não logrou a adesẫo da Conferencia de Criminologia, que de acordo com uma das conclusões de NARcelio de QUEIroz, julgou "perigosa e inconveniente a enumeração, como está feita, das causas de inimputabilidade". Sugeriu HeItor CarriLho que se dissesse: "Carecem de imputabilidade aqueles que, em virtude de psicopatia, nẫo possuirem a capacidade de normalmente determinar os proprios atos, ou os que, no momento de delinquir, tiverem revelado profunda perturbação psíquica que importe em grave perturbação da conciencia. Se a capacidade de normal determinação dos proprios atos, não estando abolida, estiver, entretanto, sensivelmente diminuida por algum dos motivos acima especificados, previamente. indagados em pericia psiquiátrica, a imputabilidade será restrita" A fórmula do ilustre psiquiátra é digna do maior apreço Tem, entretanto, dois defeitos, em meu humilde parecer: o núcleo central é uma palavra técnica de medicina (psicopatia), que ainda não se incorporou á linguagem quotidiana, e que é por isso mesmo de compreensão dificil para os leigos; e, além disso faltam á redação proposta a concisão e a clareza indispensaveis aos preceitos da lei e especialmente aos preceitos da legislação penal.

$A$ expressẫo "alienação mental" de que usam o ante-projeto $e$ o projeto argentino, não será talvez perfeita, mas é a menos imperfeita das que têm sido alvitradas até agora, para compreender os casos de insanidade mental, congênita ou adquirida, permanente, duradoura ou passageira. Di-lo, entre nós, Frando da Rocha. Repete-o, com a sua autoridade insuperavel, Afranio Peixoto (Psico-patologia forense, p. 149). "Alienaçâo mental é o conjunto de estados patológicos em que perturbações mentaes apresentam um caráter anti- 
social. E' a fórmula de Duprḱ, que resume o conceito do maior número de psiquiatras modernos sôbre esse assunto dificil. Resolve, entretanto, admiravelmente a questão. De fato, o aspecto social foi sempre o dominante no conceito da alienaçâo mental... Não importa que a v:scera doente seja o cérebro, órgão da vontade, da inteligência, da conciencia: só será alienado aquele cujo sofrimento o torne incomparavel ao meio social. Pouco importa a espécie de doença mental de que isso resulta: a consequencia será a mesma. Isso interessa apenas aos que o tratam para curá-lo: para a sociedade é apenas um individuo que pratica atos extravagantes, sem motivação razoavel, perigoso para sï e para os outros que ela protege, e do qual se defende pelo direito penal, pelo direito civil, e pelo direito administrativo".

$\mathrm{Na}$ indicação do criterio psicológico, o ante-projeto acompanha a grande maioria dos códigos e projetos modernos. $O$ estado mórbido, existente ao tempo do crime, deve ser de tal natureza que prive o agente da capacidade de compreender a criminalidade do fato ou de se determinar de acordo com essa apreciação. E', em substancia, a linguagem empregada pelo projeto suisos de 1918, que reaparece, vertida para o castelhano, no código do Peru ("aquele que... nâno possuia no momento de agir a faculdade de apreciar o caráter delituoso de seu ato ou de se determinar de acordo com essa apreciação)": e que reponta no codigo iugo-eslavo e muitos outros.

Além dos casos de insanidade mental, ha considerar os de imaturidade: selvicolas, surdos-mudos e menores.

Quanto a estes ultimos, o ante-projeto mantem o direito vigente, que faz começar aos 18 anos a maioridade penal. Até então, uin regime especial de educação ou reducaçẫo disciplinar. De então por diante até aos 21 anos, o regime comum, aplicado com certa brandura. E' o communis opinio expressa por FloRIAN: "Secondo noi la maggioritá penale sarebbe a fissarsi agli anni 18, con qualche diminuzioni e variazioni in confronto degli adulti, fino agli anni 21" (Tratt. I, p., 510). Aparta-se, neste particular, do projeto da Comissão e da lição de Costa E Silva, que transferem para o código dos menores tudo quanto respeita á delinquencia juvenil; e adota o purecer de Eusebio Gomes e JoRge CoLL, na justificação do projeto argentino, e de Ataliba Nogueira, em sua precitada monografia.

Quanto aos surdos-mudos, o ante-projeto se deixa guiar pelo ensinamento de RuIz MAYA (Psiquiatria Penal y Civil, p. 377). "El infractor ineducable debe ser aislado de la vida social por escasamente intimidable y siempre peligroso. El educable no educado e instruido deberá ser entregado a un estabelecimiento de sordosmudos de onde saldrá en su dia, sometido a vigilancia familiar. El 
instruido, delincuente, también exige la vigilancia familiar y aun la social aparente uma vez vuelto a la colectividad. Este y aquél son intimidables, pero peligrosos"

Com referencia aos selvicolas, a solução que se impõe é evidentemente a internação em instituto de trabalho obrigatorio.

Questâo tormentosa é a da imputabilidade restrita, conceito que - projeto da Comissão consagrou e a Conferencia de Criminologia não repeliu, sem embargo da cerrada argumentação desenvolvida pelo ilustre professor Corrêa de Araujo.

A exemplo da grande maioria das legislações contemporaneas, o ante-projeto reconhece a existencia de uma zona fronteiriça on intermédia, ocupada por certos individuos, que não podem ser classificados nem entre os psicopatas, nem entre os normaes. Conforme a observação perspicua de Evaristo DE MoraEs, as objeções contra o reconhecimento da imputabilidade restrita perderam muito de sua importancia, deante da solução que as novas legislações têm daảo ao problema. $O$ que, com efeito, repugnava aos que não admitiam a limitação da imputabilidade era a atenuação da pena, para o desequilibrado, o paranoide. o epiléptico, o toxicômano e outros de igual temibilidade, que seriam assim benificiados. Mas a adoção das medidas de segurança desmonta a objeção. Cumprida a pena, por individuos daquela ordem, socialmente perigosos, a sociedade não fica desarmada contra eles. Ao contrario: lança mão de novos meios de defesa.

Qual a maneira por que taes delinquentes devem ser tratados? Varios são os alvitres, que disputam a preferencia dos entendidos.

Primeiro: a medida de segurança ha de preceder necessariamente á pena, porque só depois de tratado e curado o agente a pena se tornará eficaz. E' a tese defendida, entre outros, por MATHÉ (La responsabilité attenuée, p. 105).

Segundo: em regra, o cumprimento da pena tem de preceder á execução da medida de segurança; porque de outra fórma a eficácia da pena viria a ser anulada ou diminuida, pela decorrencia de um largo periodo entre o cumprimento de uma e a execuçâo da outra. $E^{\prime}$ o sistema vencedor nas ultimas refórmas (códigos romeno e italiano, projetos alemão, autríaco, suisso) e no projeto da Comissão Legislativa.

Terceiro: a pena deve desaparecer, absorvida pela medida de segurança; porque seria crueldade começar por infligir pena a quem não é inteiramente normal; e esperar, para infligi-la, a cura do agente seria punir individuo diferente daquele que cometeu o crime. E' a teoria positivista, vitoriosa no código russo e no projeto. Ferri. 
Nenhuma das sugestões apontadas tem escapado á censura dos competentes. Leia-se, por exemplo, o que diz a respeito RuIz MaYa (p. 16 e s.).

Parece, entretanto, que a melhor solução desse problema realmente complexo seria a internação do condenado em estabelecimento especial, onde simultaneamente cumprisse a pena detentiva, sob regime compativel com o seu estado de saude, e recebesse o tratamento adequado. Na hipótese de cura dar-se-ia a transferencia para estabelecimento comum, onde seria cumprido o restante da pena. $\mathrm{Na}$ hipótese contraria, findo o tempo da segregação, caberia a imposição da medida de seg:urança aconselhavel no caso, de acordo com a periculosidade do individio.

$E^{\prime}$ o que determina o ante-projeto. E', em substancia, o que prescrevem o projeto argentino de 1937 e o código dinamarquês de 1930. E'. em suas linhas geraes, o que sugere J. Pereira Lira, relator da materia na precitada Conferencia de Criminologia, ao lembrar a creação de uma medida de segurança sui generis, cm que "a segregação do paciente participaria simultaneamente da natureza de custódia e de tratamento, em absoluta conjugação, sujeita a um prazo minimo de cominaçâo variavel e sem prazo maximo fixado".

Declara terminantemente o ante-projeto que nem os estados emotivos ou passionaes, nem a embriaguez voluntaria serão causas de isenção ou diminuição da pena. Os primeiros incluir-se-ão, quando determinada por ato injusto de outro, entre as circunstancias que atenuam a gravidade do crime. A segunda, quando preordena$d a$, entre as circunstancias agravantes; $e$, quando habitual, entre as que autorizam a imposição de medidas de segurança.

Define o criminoso de ocasião, o criminoso por tendencia, o reincidente e o habitual. Afasta-se do projeto da Comissão, porque não aceita a distinção, já averbada de empírica e metafísica, entre criminosos corregiveis $e$ incorregiveis. Afasta-se do projeto, e tambem do código italiano, porque não vê motivo para distinguir da habitualidade o profissionalismo: este é uma variedade daquela e não exige tratamento diferente.

Regula pormenorisadamente a reincidencia genérica, a espectfica $e$ a reiterada. Reincidencia, habitualidade e tendencia a delinquir são tratadas severamente, por isso que denunciam, no dizer de criminalista famoso, um estado mais profundo, permanente, orgânico do agente. A primeira é de facil verificação. As outras dependem de estudo minudente e acurado da personalidade do criminoso; e por isso mesmo é preciso cercar de cautelas a sua verificação, dada a gravidade das consequencias que resultam da classifica- 
ção do delinquente em qualquer das mencionadas categorias. Dai, a exigencia do pronunciamento do tribunal superior, em recurso necessario; dai, a exigencia de quorum maior para a declaração.

7 - Versa o ante-projeto no titulo IV a materia das penas, deixando para tratar nos dois titulos seguintes das medidas de segurança aplicaveis aos adultos $e$ das medidas tutelares ou reeducativas aplicaveis aos menores.

Tanto basta para evidenciar que não abraçamos neste ponto a solução unitaria propugnada pela escola positiva. Estamos com o projeto da Comissão Legislativa e com o código italiano.

Somos, em tese, pela concepção dualista. Medida de segurança e pena são institutos diferentes em seus fundamentos, en sua natureza, em seus objetivos. A pena (escreve Bataglini) é reação contra fatos singulares, avaliados sob o aspecto ético-jurídico, de acordo com o grau da culpa, resolvendo assim um problema de justiça; enquanto que a medida de segurança consiste numa decisâa administrativa, que serve tâo sómente para defender a sociedade contra o perigo representado por certas pessoas, em razão de suas condiçôes subjetivas. Nada, porém, impede (são palavras de ALFREDo Rocco), que, embora estranhas ao direito penal, as medidas de segurança constem do código penal, por motivos de conexão de materia e de economia de funções e de procedimento; porque nada impede que a lei confie ao juiz criminal taes funções administrativas de policia. Leia-se a proposito a demonstração de Ataliba Nogueira em sua excelente monografia ( $p .109$ e s.).

Mas, embora estivessemos convencido do contrario, não poderiamos adoptar, em face do nosso direito constitucional a concepção monista. Fiel á tradição brasileira (constituição de 1891, art. 72 \$ 20, constituição de 1934, art. 113 n. 29), a constituição de 1937, art. 122 n. 13, declara que "não haverá penas corporaes perpetuas" Tanto vale dizer que a lei ordinaria não poderá estabelecer penas corporaes por tempo indeterminado. Ora, medida de segurança e prazo determinado são cousas que se repelem, porque, conforme disse AlFREDo Rocco, ao justificar o projeto que se converteu no atual código italiano, "qualquer prefixação de limite está em manifesto contraste, sobretudo prático, com a própria indole das medidas de segurança, e tambem em contradição logica com a natureza de uma decisão de cunho tipicamente administrativo, que pode ser revogada a qualquer momento".

Deante disso, não seria constitucionalmente possivel reunir as penas e as medidas de segurança debaixo da rubrica de sançôes, como fazem os códigos do Mexico e de Cuba e o projeto argentino de 1937. 
As penas, que propomos, são as de reclusão, detenção, segregação e multa. Não ha penas acessorias: a publicação da sentença, a confiscação dos instrumentos e proventos do crime, a inhabilitação para o exercicio de direitos, considerâmo-las efeitos necessarios da condenação a determinadas penas ou por certos crimes.

Não propomos o restabelecimento da pena de morte, que a República aboliu. Inutil seria reabrir um debate secular, em que se esgotaram, de parte a parte, todos os argumentos. Basta a convicção, que temos, de que as condições atuais do meio brasileiro não exigem a adoção de uma penalidade, contra a qual se levantam objeções da maior gravidade e transcendencia.

Ressalvada a nossa maneira de encarar o problema, deixamos a soluçâo ao criterio do Governo; e, a exemplo de JoRge CoHL e EuSEBIo GoMEZ, autores do projeto argentino, redigimos as disposições correspondentes, para o caso do Governo entender de usar da faculdade conferida pelo art. $122 \mathrm{n}$. XIII da lei constitucional em vigor.

Com referencia ás penas privativas da liberdade, o ante-projeto se desvia do projeto da Comissão Legislativa, que, ao discipliná-las, entra nos pormenores de sua regulamentação, o que se nos afigura materia do código penitenciario. Indicam-se os atributos que caracterizam a reclusẫo e a detenção, e nada mais. Uma e outra acarretam a obrigação do trabalho, a que corresponderá o salario merecido. Deste uma parte se destinará a compensar as despesas de manutenção do sentenciado; outra a indenizar o dano ex delicto. São inovações, consagradas em varios códigos modernos e cujo alcance não precisamos encarecer.

Regulados o livramento condicional e a condenaçâo de execução condicional, passa o ante-projeto a ocupar-se da pena pecuniaria. Vários os pontos, em que obedecemos a orientação contrária á da Comissão Legislativa. Deles o mais importante é o da conversibilidade da multa em pena detentiva, único meio de que dispõe o legislador para assegurar-lhe eficazmente a execução.

$O$ capitulo seguinte traça as normas a que deve obedecer o juiz na aplicação da pena. Esse, um dos problemas cruciais em materia repressiva. Sistema, como é o do ante-projeto, inspirado todo ele na necessidade de prevenir o crime e de tratar o criminoso de acordo com a sua maior ou menor periculosidade, depende, para o seu êxito, da maneira por que usar o juiz dos podercs que lhe são outorgados. Cabem aqui as palavras de Cosentini: "Il faut bien considérer qu'en raison de l'orientation actuelle de la législation pénale, la tâche du juge est devenue extrêmement difficile, de façon que ne lui suffisent plus les notions de droit pénal acquises à l'Université. Il doit être en mesure de faire un analyse approfondie des 
précédents du criminel, de son milieu, de ses tendances, de ses anomalies bio-psychiques, des circonstances aggravantes ou atténuantes qui ont accompagné l'infraction. Il doit donc être doté d'une fine intuition psychologique, d'une vaste connaissance das sciences biologiques et sociologiques, d'une grande expérience de la vie, de nature à lui permettre d'apprécier les circonstances pour ou contre l'accusé et de prononcer une sentence qui soit une synthèse de cette appréciation. Son prononcé n'est plus alors le résultat d'une simple opération arithmétique sur la durée de la peine augmentée ou diminuée suivant les données du Code même. Son pouvoir discrétionnaire lui permet de prendre le point de départ entre le minimum et le maximum de la peine fixée par le Code, d'augmenter ou diminucr cette peine de base, selon la libre appréciation des circonstances. La sentence est donc la conséquence de tout une série d'appréciations, d'une étude approfondie du criminel et de son milieu. Plus encore. La sentence prononcée, la tâche du juge ne s'arrête pas là. Il suit le criminel pendant l'expiation de la peine...".

Estará a nossa magistratura preparada para uma tarefa dessa magnitude? Ninguem o afirmará, sem afronta á evidencia. Daí, a timidez, ou, melhor, a prudencia do ante-projeto, que adota o sistema da pena relativamente determinada, fixando "per ogni forma di reato e per ogni motivo, che influisca sull'imputabilità o sulla quantità del reato, la especie della pena ed $i$ limiti di quantità fra $i$ quali pud spaziare il giudice": e que dita ao juiz " $i$ criteri direttivi, alla stregua dei quali si debba stabilire in concreto la pena nei limiti fissati dalla legge in relazione ai singoli casi" (FLORIAN, II, n. 704).

Não seria prudente, com efeito, passarmos de um regime, ccmo o atual, que não concede ao juiz o menor arbitrio na escolha da qualidade e na fixação da quantidade da pena, para o regime oposto. Assim, o ante-projeto julga prematura a outorga de certos poderes a magistratura penal, que o projeto da Comissão Legislativa consagrava: a livre atenuação da pena e o perdão judicial. Este, o ante-projeto admite no caso especialissimo de excesso na execução de ordem da autoridade competente, da legitima defesa e do estado de necessidade. E' alguma cousa. E' quanto basta no atual momento. Mas, apesar de tudo, muito maior será no regime do ante-projeto, do que no regime vigente, o âmbito em que poderá mover-se o julgador na aplicação da pena, para adequá-la á personalidade do criminoso; tanto mais quanto a distancia entre o máximo e o minimo, estabelecidos para cada especie de infração na Parte Especial, é, em regra, tamanha, que permite ao poder judiciario uma grande liberdade na determinaçẫo da quantidade da pena aplicavel. 
Entre os efeitos necessarios da condenação, quaesquer que sejam o crime ou a pena, figura a obrigação de reparar o dano.

Em nota ao artigo correspondente do ante-projeto enunciamos os motivos que nos levaram a manter o direito vigente. Somos pela independencia da ação criminal e da ação civil. O que fazemos é direta $e$ indiretamente constranger o criminoso ao adimplemento da obrigação que lhe incumbe. Assim, uma parte do salario do sentenciado se destinará á indenização do dano. Assim, o sentenciado não poderá gozar de certos beneficios (liberdade condıcional, suspensão da execução da pena, rehabilitação), antes de haver efetuado a reparação devida ou demonstrar a impossibilidade de efetuá-la.

Medida que se impõe e que vae constar das disposições finais do ante-projeto é a instituição de uma Caixa de Reparaçôes. Lembrou-a a Comissão italiana presidida por Enrico Ferri, dando vida nova a uma ideia esboçada na reforma penal toscana (1756) e na legislação das Duas Sicilias (1815). A sugestão alcançou vitória mais ou menos completa nos codigos peruano, italiano e cubano e no último projeto francês. E' pensamento nosso organizar a Caixa nos moldes da peruana. Os fundos serão constituidos pelo produto da venda dos objetos confiscados aos criminosos, por uma quota-parte dos salarios dos condenados pela importancia das multas pagas, das cauções perdidas e das indenizações não reclamadas por quem de direito, e, enfim, por eventuais contribuições voluntarias. Assim aparelhada, a Caixa terá por objetivo adeantar á vitima do crime ou á sua familia, quando o exijam as circumstancias, uma parte da reparação, ficando com o direito de rehaver a qualquer tempo do condenado os adeantamentos feitos; indenizar as vitimas de erros judiciarios; prestar assistencia de que precisar a familia do preso preventivamente e do sentenciado; ocorrer ás despesas com os patronatos dos egressos, dos liberados condicionalmente e dos menores.

8 - A Conferencia de Criminologia e o projeto da Comissão Legislativa não acolheram o sistema das medidas de segurança preventivas ou pre-delictivas, que, por enquanto, só conseguiu vingar no código penal uruguaio e no código cubano de defesa social. Não o acolhe tambem o ante-projeto: para que se justifique a imposição de tais medidas, nâo basta a possibilidade de que o individuo venha a cometer um delito: é essencial a probabilidade de que venha a praticá-lo; probabilidade quc se não pode presumir sem uma violação anterior da lei penal.

Para Consentini, a materia está admiravelmente definida e organizada pelo legislador italiano, que fez obra superior á dos projetos $e$ textos dos códigos posteriores. De pleno acordo. Neste, e em outros lances, tomamos por modelo o trabalho de ALFREDo Rocco. 
Dele só nos afastamos no que se refere á confiscação, que, a nosso ver, se classifica melhormente entre os efeitos necessarios da sentença; no que respeita á clausura do estabelecimento, que AlFredo Rocco não previu, e que já foi consagrada por varias codificações, como a cubana (1936) e a romêna (1936), e pelo projeto francês de 1934; e, finalmente, no que toca á internação dos sentenciados de imputibilidade restrita, que o código italiano faz suceder ao cumprimento da pena, e que com o cumprimento da pena se executa no sistema do ante-projeto.

Extremamente lacunoso é neste particular o texto elaborado pela Comissão Legislativa. Procuramos supri-las, tendo sempre em atenção o voto formulado por Ataliba Nogueira (p. 252): "Afigura-senos.. de absoluta necessidade ser de todo refundido o capitulo do projeto... afim de serem acrescentadas as regras indispensaveis para a prognose da periculosidade; a possibilidade de aplicação de medidas de segurança pelo juiz da execução, qulando o não tenha sido pelo juiz da causa; as normas do reexame da periculosidade, após o decurso do periodo mínimo da duração; a regra a observar-se nas hipóteses de cúmulo das infrações; do efeito da extinção do crime $e$ da pena sobre a aplicaçẫo e execução das medidas de segurança, os casos de suspensão ou de transformação das medidas. Tudo isso, a par das medidas de criterio de fixação do quantum das medidas $e$ das regras geraes de sua execução, e tambem do modo de proceder nos casos de inobservancia ou transgressão das medidas por parte do individuo perigoso, assim como do regime educativo, curativo $e$ de trabalho" Em taes censuras não incorre o ante-projeto. Tem razão o ilustre criminalista: "se é justo evitar-se minúcia própria de regulamento, tambem é desaconselhavel... tal economia de normas que ráia pela carencia".

Nada mais diriamos a propósito, se não fôra a necessidade, em que nos vemos, de expôr os motivos por que divergimos de uma das conclusões aprovadas pela Conferencia de Criminologia.

Dizia o projeto que as medidas de segurança seriam aplicadas "de acordo com a lei vigente no momento da sentença" Menos do que sugere o ante-projeto que, acompanhando neste passo os códigos italiano, chinês e cubano e o projeto francês, manda prevalecer, quando diversa da lei vigente ao tempo da sentença, a que vigorar ao tempo da execução.

Por 10 votos contra 8 (Rev. de Dir. Pen., XV. p. 214), entenden a assembléa suprimir a parte final do art. 150 do projeto, visto que "a aplicação da medida de segurança instituida ao tempo da senten$c ̧ a, e$ não do crime, podia constituir sacrificio das garantias constitucionaes relativas á liberdade individual". 
Mas o que dispunha a constituição de 34 é, em substancia, o mesmo que dispõe a de 37: "As penas estabelecidas ou agravadas na lei nova não se aplicam aos fatos anteriores".

Estaräo as disposições do ante-projeto em conflito com o preceito constitucional?

Não.

Porque, antes de tudo, a especie não é de pena, e sim de medida de segurança; e não ha confundi-las, adotada a concepção dualista, que considera umas e outras como entidades juridicas de todo em todo distintas.

Porque, além disso, o que reclama a defesa das garantias individuaes é que se respeite o principio da legalidade, tanto em relação ás penas como em relaçâo ás medidas de segurança. Esse principio, respeita-o o ante-projeto no que se refere ás ultimas, como no que toca ás primeiras. A fonte única e exclusiva de umas e de outras é a lei. Dos dispositivos que sugerimos poder-se-á dizer o que diz Florian ( $I I, p .904)$ dos que lhes correspondem no código italiano: deixam êles a salvo "non solo... il principio nulla poena sine lege (nessuna misura di sicurezza fuori della lege), ma anche $i$ principii nulla poena sine crimine, nullum crimen sine lege nel senso che l'applicazione iniziale della misura di sicurezza è sempre legata o ad un reato o ad un fatto di reato, circoscritto e determinato, od alla violazione di obblighi o prescrizioni imposte dalla stessa legge penale".

Porque, enfim, não se trataria de aplicação da lei a fato anterior, mas a fato atual, que é a periculosidade, no caso de imposição de medida de segurança. E' o que bem explica Florian (p. 217): "Poicchè loro presuposto è la pericolosità, la cui efficienza non pud essere che attuale, vale sempre la legge del tempo di loro applicazione, anche se sia diversa dalla precedente o nuova. L'applicazione, s'intende, sia come irrogazione sia come effettiva attuazione. Irrelevante del tutto $\dot{e}$, quindi, la circostanza che la legge nuova sia piu leggera della precedente"

9 - Objeto do titulo seguinte é'o regime da menoridade, e do VI e último a ação criminal.

Ao disciplinar essas duas materias, o ante-projeto mantem em suas linhas mestras a legislação vigente.

Uma das poucas inovações que propomos é a atribuição do direito de queixa aos sindicatos profissionaes, em se tratando de crime de exercicio ilegal. E' o que se verifica em França, desde a lei de 30 de novembro de 92 (art. 17). E' providencia aconselhavel para a melhor repressão de infrações daquela especie.

Em materia de prescrição ha assinalar a dispositivo, que declara quando se reputam cometidas, para o efeito da contagem do pra- 
zo, o crime tentado, permanente, continuado ou sucessivo, e aquele cuja punibilidade estiver subordinada a uma condição; o que, em se tratando de criminoso reincidente, habitual ou por tendencia, faz defender a prescrição da pena detentiva, não só do transcurso do prazo, como tambem do bom comportamento do condenado, durante esse periodo; o que declara prescritos o crime e a pena, ainda nos casos de suspensão ou interrupção, quañdo excedido de mais de metade o prazo legal.

Taes, sr. Ministro, em resenha ligeira, os pontos capitaes do ante-projeto, que vimos submeter ao juizo esclarecido de V. Ex.

Da refórma penal, nos termos em que a esboçamos, podemos dizer o que EnRICo FerRi disse de seu projeto e repetiram Eusebio GOMEs e JORGE Colt, na justificação do novissimo projeto argentino.

A eficácia plena da aplicaçấo da nova lei dependerá de duas condições, que estão nas mãos do Governo realizar: a preparação especializada da magistratura e a creação de estabelecimentos destinados á readaptação de certos delinquentes, á reeducaçâo de outros, ao tratamento de muitos.

Quanto a primeira condição, lembraremos que, entre os temas do $1 .^{\circ}$ Congresso Internacional de Criminologia, a realizar-se em Roma nos ultimos dias de Setembro do ano corrente, figura "o papel do juiz na luta contra a criminalidade e o seu preparo criminológico". Nâo mais se trata de saber se é necessaria a especialização da magistratura, ponto em que (dizem os organizadores do programa) a unanimidade é completa; e sim da maneira por que se deve operar a especialização (cursos universitarios, post-universitarios, culturais), e do problema da creação de juizes de carreira ou triburıais mixtos de que participem tecnicos estranhos á magistratura. Quanto aos estabelecimentos adequados, parece-nos que a melhor solução seria a creação de institutos regionais, a cargo da União. Mas não bastará creá-los: indispensavel será entrega-los a pessoal competente, o qué tambem somente se conseguirá pela especialização.

$A^{\prime}$ insigne demonstração de confiança, com que nos honrou o Governo Federal, procuramos corresponder, empenhando-nos por que a obra, a que votámos o melhor de nossas energias, não fosse indigna da cultura juridica do país e contribuisse para dar a necessaria eficiencia á defesa da coletividade contra o crime. Diz-nos a conciencia que só procurámos ter deante dos olhos a verdade juridica $e$ os supremos interesses da pátria.

S. Ṕaulo, 15 de Maio de 1938. 


\section{Projeto do \\ Codigo Criminal Brasileiro}




\title{
LIVRO I
}

\section{PARTE GERAL}

\author{
TITULO I
}

\section{Da aplicação da lei criminal}

Art. $10^{\circ}$ - Não ha crime sem lei anterior que o qualifique, nem pena sem prévia cominação legal.

$\S$ único - Rege-se, todavia, pela lei vigente ao tempo da sentença a aplicação das medidas de segurança.

Projéto Sá Pereira, revisto, art. $10^{\circ}$ - Não ha crime sem lei anterior que o qualifique, nem pena sem cominação legal previamente esta-. belecida.

Consolid. Piragibe, art. $10^{\circ}-$ Ninguem poderá ser punido por fáto que não tenha sido anteriormente qualificado crime, nem com penas que não estejam previamente estabelecidas. A interpretação extensiva por analogia ou paridade não é admissivel para qualificar crimes ou aplicarlhes penas.

Art. 2.0 - Retroagirá a lei vigente ao tempo da sentença ou de sua execução:

I - que não mais considere o fato passivel de pena;

II - que de outra maneira favoreça o agente.

$\S 10^{\circ}-$ Se já houver sentença condenatoria cessarão, no pri meiro caso, a sua execução e os seus efeitos penais; e no segundo o julgamento se reajustará às determinações posteriores.

§ $2 .^{\circ}$ - Não caberá o disposto neste artigo, quando fôr exce. eional ou temporaria a lei anterior. 
Proj. 2 - Ninguem será punido pelo fato que tiver deixado de ser crime em virtude de lei posterior, e, se já existir condenação, cessam a sua execução e os seus efeitos penais. $3 .^{\circ}-\mathrm{A}$ lei vigente no momento do crime determina a pena; aplicar-se-á porém, a que estiver em vigor por ocasião do julgamento, se for mais branda. Quando posterior ao julgamento a lei mais branda, a esta reajusta-se a pena.

Cons. 2 - A lei penal não tem efeito retroativo; todavia o fato anterior será regido pela lei nova: a) se não fôr considerado passivel de pena; b) se fôr punido com pena menos rigorosa. § único - Em ambos os casos, embora tenha havido condenação, se fará aplicação da nova lei, a requerimento da parte ou do M. P., por simples despacho do juiz ou do tribunal que proferiu a última sentença.

Art. $3 .^{\circ}$ - Ressalvadas as exceções constantes de convenções, tratados e normas universalmente aceitas do direito internacional, aplicar-se-á a lei brasileira aos crimes que, no todo ou em parte, sejam cometidos ou devam produzir os seus efeitos no territorio nacional ou em outro lugar submetido à jurisdição do Brasil.

Proj. 4 - A lei criminal aplica-se a todos os que no territorio nacional a infringirem, com resalva, porém, das convenções e tratados, e dos principios de direito internacional que regem as imunidades diplomaticas, o territorio ficticio e a pirataria.

Cons. 4 - A lei penal é aplicavel a todos os individuos sem distinção de nacionalidade que, em territorio brasileiro, praticarem fatos criminosos e puniveis. Incluem-se na definição de territorio brasileiro: a) os portos e mares territoriais; b) os navios brasileiros em alto mar; c) os navios mercantes extrangeiros surtos em porto brasileiro.

Art. $4^{\circ}$ - Ficam sujeitos à lei brasileira, embora cometidos no estrangeiro:

I - os crimes :

a) contra a Nação Brasileira (tit. I, cap. I, da Parte Especial) :

b) contra o crédito ou a fé pública da União, dos Estados e dos Municipios;

c) contra os bens do patrimonio federal, estadual ou municipal existentes fóra do país;

d) cometidos por funcionarios contra a administração pública (titulo II). 
II - os crimes :

a) que por convenção ou tratado o Brasil se tenha obrigado a reprimir;

b) de que seja vítima, ou agente, um brasileiro, se concorrerem as condições constantes do $\S 2 .^{\circ}$ deste artigo.

$\S 10^{\circ}-$ Nos casos do $n .^{\circ}$ I proceder-se-á até ao julgamento, inclusive, ainda que o agente se ache ausente ou já tenha sido julgado no estrangeiro.

$\S 2 .^{\circ}-$ Nos casos do n..$^{\circ}$ II não se procederá, senão verificado o concurso das seguintes condições:

a) encontrar-se o agente no territorio nacional;

b) ser tambem punivel o fato no país em que houver ocorrido;

c) incluir-se o crime entre aqueles que, de acordo com a lei brasileira, autorizam a extradição;

d) não ter sido o agente absolvido ou perdoado no estrangeiro ou não ter aí cumprido a pena imposta;

e) não se haver dado a prescrição do crime, ou da pena, segundo a lei mais favoravel;

f) existir queixa da parte ou requisição do Procurador Geral da Republica.

Pr. 4 - Embora ausente ou já tenha sido julgado em outro país, estará sujeito à lei brasileira aquele que no estrangeiro cometer crime: I - contra a paz interna e as relações internacionais do Brasil; II a sua defesa, indepêndencia e integridade; III — as suas instituições politicas; IV - o credito, ou a fé publica da União, ou dos Estados; V - a vida ou a liberdade do Presidente da Republica ou dos presidentes dos Estados; VI - a função em que tiver investido o Governo Brasileiro. Art. 6. ${ }^{\circ}$ Desde que entre no territorio nacional, estará sujeito à lei brasileira: I - aquele que, no estrangeiro, cometer crime, que o Brasil se tenha obrigado a reprimir, por convenção ou tratado; II aquele que, por crime cometido no estrangeiro contra brasileiro, não tiver sido julgado, ou não tiver cumprido pena imposta na sentença estrangeira; III - o nacional que, fóra do país, cometer crime pelo qual a lei brasileira admita a extradição. § $10^{\circ}$ - Este artigo será aplicavel ao naturalizado brasileiro, desde que, com a naturalização posterior ao crime, maliciosamente se evitar a repressão do país estrangeiro. § $20^{\circ}-\mathrm{A}$ aplicação deste artigo cessará quando, em correspondência com algum dos casos nêle previstos, se verificar: I - não ser o fato reprimivel 
como crime no país em que tiver ocorrido; II - por êle, no extrangeiro, haver sido o inculpado absolvido, haver cumprido pena, ou the ter sido perdoada; III - estar prescrito o crime ou a pena, segundo a lei de um òu de outro país.

Cons. 5 - E' tambem aplicavel a lei penal: I - Ao nacional ou estrangeiro que regressar ao Brasil, espontaneamente, ou por extradição, tendo cometido fora do país os crimes de homicidio e roubo em fronteiras e não tendo sido punido no lugar onde delinquiu; II - Aos brasileiros ainda que ausentes da Republica, que perpetrarem algum dos crimes: a) contra a independência, integridade e dignidade da patria (arts. 87̈, 92, 94, 98, 101, 102 e 104); b) - contra a Constituição da Republica e forma do seu governo (art. 107 e $\S$ único); c) - de moeda falsa (arts. 239, 240 e 242) ; d) - falsificação de titulos e papeis de credito do Governo Federal, dos Estados e dos Bancos (arts. 245 e 250). § 1. 0 julgamento de tais criminosos, porém, se tornará efetivo quando houverem êles regressado espontaneamente ou por extradição ao país. $\S 2 .^{\circ}-0$ processo de julgamento de estrangeiros que cometerem alguns dos crimes enumerados neste artigo só se efetuarão quando os criminosos espontanea ou forçadamente vierem ao país. III - Poderá ser processado e julgado no Brasil o nacional ou estrangeiro que, em territorio estrangeiro, perpetrar crime contra brasileiro e ao qual comine a lei brasileira pena de prisão de dois anos no minimo. $\S 10^{\circ}-0$ processo contra 0 nacional ou estrangeiro só será iniciado mediante requesição do Ministerio do Interior ou queixa da parte quando, nos casos em que a extradição é permitida, não fôr ela solicitada pelo Estado em cujo territorio fôr cometida a infração. $\$ 20^{\circ}$ - Não terão logar o processo e o julgamento pelos crimes referidos no n..$^{\circ}$ III se os criminosos já houverem sido no estrangeiro, absolvidos, punidos ou perdoados por tais crimes, ou se o crime ou a pena já estiverem prescritos segundo a lei mais favoravel. 0 processo e o julgamento dos crimes do n. ${ }^{\circ}$ II, não serão obstados por sentença ou qualquar ato de autoridade estrangeira. Todavia, será computada no tempo da pena, a prisão que no estrangeiro tiver, por tais crimes, sido executada.

Art. 5..$^{\circ}$ - A pena cumprida no estrangeiro computar-se-á, quando identica, na que impuserem pelo crime os tribunais brasileiros, ou influirá, quando diversa, para atenuá-la.

Pr. 8 - A pena cumprida no estrangeiro imputar-se-á quando identica, na que a justiça brasileira, pelo mesmo crime impuser, ou influirá para atenua-la, quando diferente.

Cons. - Omissa. 
Art. $60^{\circ}-$ A sentença proferida por tribunal estrangeiro será reconhecida no Brasil:

I - para estabelecer a reincidência, a habitualidade e a tendencia a delinquir;

II - para sujeitar o condenado, enquanto se encontre no territorio nacional, à reparação do dano, às medidas pessoais de segurança e à interdição ábsoluta ou relativa resultantes da condenação; uma vez que:

a) a aplicação da lei brasileira acarrete, na especie, as mesmas consequências;

b) haja tratado de extradição com o Estado de cuja autoridade judiciaria emanar a sentença; ou, na falta de tratado, requisição do Ministro da Justiça ou pedido da parte interessada na reparação do dano ou em outros efeitos civis da sentença.

Pr. 7 - As consequências acessorias da condenação, que importarem na restrição da capacidade, do exercicio de direitos, da atividade profissional, ou em medida não detentiva de segurança, poderão ser aplicadas ao condenado no estrangeiro que se encontrar no país, concorrendo porém as seguintes condiçōes: I - acarretar necessariamente a condenação, se a sentença fôr proferida no Brasil, alguma daquelas consequências; II — requerem o Ministerno Publico a sua aplicação; III não optar o condenado brasileiro, previamente ouvidos, por novo julgamento perante a justiça do país.

Art. $70^{\circ}-$ Computam-se os prazos, em materia penal, incluindo o dia do comego.

$\S 10^{\circ}$ - Os dias e os meses computam-se pelo calendario comum.

§ 2..$^{\circ}$ - Desprezam-se no cômputo das penas privativas da liberdade e das medidas detentivas de segurança as fracções de dia, e no da pena pecuniaria as fraçẽes de dez mil réis.

Pr. 115 - As penas privativas da liberdade... medem-se por dias, meses e anos, sendo o dia de 24 horas, o mês de 30 dias e o ano de 12 meses.

Cons. - Omissa. 
Art. $8^{\circ}$ - As disposições gerais deste Código aplicam-se aos crimes punidos por leis especiais, quando estas não disponham expressamente o contrario.

Pr. II - Salvo disposição expressa em contrario, a legislação especial sobre o crime, a contravenção e a pena regular-se-ão pelos principios gerais deste Código.

Cons. $4^{\circ}$ - A lei penal é aplicavel a todos os individuos sem distenção de nacionalidade, que, em territorio brasileiro, praticarem fatos criminosos e puniveis. Art. $60^{\circ}$ - Ssta Consolidação não compreende: a) - os crimes de responsabilidade do Presidente da Republica; b) os crimes puramente militares, como tais declarados nas leis respectivas; c) - os crimes não especificados nela, contra a policia e economia administrativa dos Estados, os quais serão punidos de conformidade com as leis peculiares de cada um.

\section{TITULO II}

\section{Do crime}

Art. 9..$^{\circ} \mathrm{O}$ agente só responderá pelo evento que fôr efeito de sua ação ou omissão.

$\S 1 .^{\circ}$ - Faltar á obrigação jurídica de impedir o evento equivale a causá-lo.

$\S 2 .^{\circ}-0$ concurso de causa anterior, simultanea ou sobrevinda, que absolutamente não dependa do fato ou da vonțade do agente e que este não possa prever, exclue a relação de causalidade entre a ação ou omissão e o evento; - respondendo nesse caso o agente pelos atos anteriores que constituam crime.

Pr. 28 - A responsabilidade pelo resultado será excluida, sobrevinda causa independente da vontade do infrator, suficiente por sì mesmo para produzi-lo, mas subsistirá quanto aos atos puniveis anteriores.

Cons. 295 - Para que se repute mortal, no sentido legal, uma lesão corporal, é indispensavel que seja causa eficiente da morte por sua natureza e séde, ou por ter sido praticada sobre pessoa cuja constituição ou estado mórbido anterior concorram para torná-la irremediavelmente mortal. $\$ 10^{\circ}$ Se a morte resultar, não da natureza e séde da lesão, e sim das condições personalissimas do ofendido... $§ 2 .^{\circ}$ Se resultar, 
não porque o mal fosse mortal, e sim por ter o ofendido deixado de observar o regimen médico-higiênico reclamado pelo seu estado...

Art. 10 - Diz-se 0 crime :

I - consumado, quando se realizam todos os elementos de sua qualificação legal;

II - tentado, quando a execução já iniciada se não consuma por circunstancias independentes da vontade do agente.

Pr. 2 - 0 crime é consumado, quando todos os elementos da qualificação nele se reunirem. 3 - 0 crime é tentado, quando a execução já iniciada não se consuma por circunstancias acidentais.

Cons. 11 - Quando depender a consumação do crime da realização de determinado resultado, considerado pela lei elemento constitutivo do crime, este será consumado sem a verifł́ação daquele resultado. 12 - Reputar-se-á consumado o crime, quando reunir em si todos os elementos especificados na lei. 13 - Haverá tentativa do crime, sempre que com intenção de cometê-lo, executar alguem atos exteriores que, pela sua relação diréta com o fato punivel, constituam começo de execução, se esta não tiver lugar por circunstancias independestes da vontade do criminoso.

Art. 11 - Não será punivel a tentativa:

I - se o agente desistir voluntariamente da execução do crime ou lhe impossibilitar a consumação, ressalvada, porém, a responsabilidade pelos atos anteriores, que por si mesmos constituam crime;

II - se tais forem a ineficácia do meio empregado ou a impropriedade do objéto, que tornem impossivel a realização do evento; podendo, entretanto, o juiz, verificada a periculosidade do agente, aplicar-lhe medida de segurança.

Pr. 411 - Nas contravenções .. a tentativa não é punivel. 4: Não é punivel por tentativa aquele que espontaneamente desiste da exécução do crime, lhe impossibiilta a consumação ou impede que ele se execute no caso do concurso. $\S 10^{\circ}$ - Este artigo é aplicavel mesmo quando as causas que impossibilitaram a consumação forem independentes da ação do desistente, se este o ignorava e seriamente se esforce por torná-la impossivel. $\S 2 .^{\circ}-0$ desistente responderá pelos atos preparatorios do crime tentado, que por si só constituirem crimes ou cantravenções. § único - Poderá ser livremente atenuada a pena da tenta- 
tiva por meio inidôneo ou contra objéto improprio: tratando-se, porém, de reincidente ou criminoso por índole, aplicar-se-á a pena de acordo com a sua periculosidade.

Cons. 16 - Não será punida a tentativa de contravenção, e nem a de crime a qual não esteja imposta maior pena que a de um mês de prisão celular. 15: Ainda que a tentativa não seja punivel, se-lo-ão os atos que entrarem em sua constituição, tendo sido classificados crimes especiais. $14 \S$ único - Não é punivel a tentativa no caso de ineficácia absoluta do meio empregado ou de impossibilidade absoluta do fim a que o delinquente se propuzer.

Art. 12 - A tentativa, a que não estiver cominada pena especial, será punida com a do crime consumado, diminuida de um a dois terços. Se a pena cominada para o crime consumado fôr a de morte, aplicar-se-á, no caso de tentativa, a reclusão por 20 a 30 anos.

Pr. 5 - A pena da tentativa é a do crime consumado; poderá, porém, ser atenuada, quando não se tratar de reincidente ou criminoso por índole.

Cons. 63 - A tentativa do crime, a que não estiver imposta pena especial, será punida com as penas do crime, menos a terça parte em cada um dos graus.

Art. 13 - Diz-se o crime :

I - doloso, quando o resultado da ação ou omissão, que o constitue, corresponde á intenção do agente;

II - preterintencional, quando o resultado previsto e querido pelo agente é menos grave do que o produzido;

III - culposo, quando o resultado não é querido pelo agente, mas deriva deste se ter havido com negligência, imprudência, imperícia ou inobservância de determinação da lei ou da autoridade.

$\S$ unico: 0 crime será punido como doloso, sempre que a lei não disponha o contrario, e como preterintencional ou culposo nos casos expressos.

Pr. 25 - Sómente estará sujeito ás disposiçōes deste Código quem as infringir por dolo ou culpa. Punir-se-á por dolo toda a vez que a lei não dispuzer o contrario e por culpa nos nossos casos expressos. 26 Responde por dolo aquele que tiver querido produzir a lesão ou crear o 
perigo causado com o seu ato, ou que o praticar quando se devessem prever como necessarias ou provaveis as consequências que dêle resultarem. 27 - Responde por culpa aquele que, agindo sem a atenção ordinaria ou a atenção especial a que fosse obrigado, ou a de que, segundo as suas condições pessoais e as circunstâncias, pudesse ser capaz, não prevê as condições possiveis de seu ato ou confia no acaso, que elas se não produzam.

Cons. 24 - As ações ou omissões contrarias á lei penal que nãu forem cometidas com intenção criminosa ou não resultarem de negligência, imprudência ou impericia, não serão puniveis.

Art. 14 - Não exime de pena o agente o erro ou ignorancia da lei penal.

Pr. 30 - A ignorancia da lei penal não exclue a responsabilidade; a ela, porém, atenderá nas infrações meramente convencionais (?), verificando que: 1) a ilegalidade é elementar na qualidade da infração; 2) a ignorancia é devida a força maior ou impossibilidade manifesta; 3) e infrator é analfabeto ou estrangeiro ainda não familiarizado com a língua do país e seus costumes. § ún. A responsabilidade será excluida: 1) verificada qualquer das hipóteses do n. 2; 2) concorrendo com a hipótese do n. 1 qualquer das previstas no n. 3. Fóra destes casos a pena poderá ser livremente atenuada.

Cons. 26 - Não diminue, nem exclue a intenção criminosa: a) a ignorancia da lei penal.

Art. 15 - Não é punivel quem pratica a ação ou omissão por erro substancial sobre o fato que constitue o crime; entendendo-se

I - que, se o erro fôr imputavel a culpa e a ação ou omissão estiver prevista como crime culposo, por este responderá o agente;

II - que, se o erro fôr devido a ter sido o agente enganado por terceiro, este responderá pelo crime.

$\S$ unico - Quando, por erro ou acidente, o crime fôr cometido contra pessoa ou cousa diversa daquela contra a qual se dirigir a ação ou omissão ou se tiver a intenção de dirigi-la, não se levarão em conta as circunstancias que derivem da condição da vítima. Atender-se-á, porém, ás circunstancias inherentes á pessoa, ou cousa, intencionalmente visada e ás circunstancias subjetivas em que tiver o agente deliberado e executado o crime. 
Pr. 106 - As unicas circunstâncias atendiveis para agravar ou atenuar a pena, no caso de erro sobre a pessoa ou sobre a diretriz da ação criminosa, serão as que respeitem á pessoa intencionalmente visada pelo criminoso.

Cons. 26 - Não diminue, nem exclue a intenção criminosa... o erro sobre a pessoa ou cousa a que se dirigir o crime.

Art. 13 - Tambem não será punivel aquele que praticar a ação ou omissão:

I - por caso fortuito ou força maior;

II - coagido por violencia física irresistivel, respondendo neste caso pelo crime o autor da violencia.

Pr. - Omisso.

Cons. $27-\S \S 5 .^{\circ}$ e $6 .^{\circ} \ldots$ os que forem impelidos a cometer $\circ$ crime por violencia física irresistivel ou ameaças acompanhadas de perigo atual ... os que cometerem o crime casualmente no exercicio ou prática de qualquer ato lícito feito com atenção ordinaria.

Art. 14 - Não será tambem punivel aquele que praticar a ação ou omissão :

I - com o consentimento de quem possa validamente dispôr do direito violado ou ameaçado;

II - em obediencia a ordem emanada de superior hierárquico, no exercicio de suas funções, uma vez que:

a) a autoridade seja competente para dar a ordem;

b) e esta não seja manifestamente ilegal, ou, por circunstancias especiais, o executor não possa ter conciencia da ilegalidade;

III - para salvar a vida, a liberdade, a honra ou outro direito relevante, proprio ou alheio, de perigo atual e grave, que o agente não haja voluntariamente provocado, não possa evitar de outra maneira e não tenha o dever jurídico de afrontar;

IV - em legítima defesa de direito próprio ou de terceiro, dado o concurso dos seguintes requisitos:

a) agressão atual;

b) impossibilidade de preveni-la ou obstá-la, sem humilhação ou perigo, por outros meios ao alcance do agente; 
c) ausencia de provocação suficiente da parte do agredido;

d) inexistencia de desproporȩão manifesta entre a gravidado da agressão ou a importancia do direito ameaçado e a repulsa.

$\S$ unico - Excedidos, nos casos dos ns. II, III e IV, os limites impostos pela autoridade, pela necessidade ou pela lei, respectivamente, diminuir-se-á a pena. Poder-se-á deixar de aplicá-la, nos casos dos ns. III e IV, quando o excesso fôr explicavel pelas circumstancias do fato ou pelas condições pessoais do agente.

Pr. 8 - Não comete crime aquele que: I - age nos limites de uma autorização do direito publico ou privado; II - executa a lei ou obedece a superior hierárquico no exercicio de suas funções; III - se opõe á execução de ordens ilegais; IV - se encontra em estado de legitima defesa; $\mathrm{V}-$ se encontra em estado de necessidade. 9: As seguintes condições são necessarias para que a obediencia hierárquica exclua a criminalidade: I - que a autoridade seja competente para dar a ordem; II - que esta não seja manifestamente ilegal, salvo quando, por condições especiais, não puder ter o executor conciencia da ilegalidade. 10 - Está em legitima defesa aquele que, usando dos meios que as circunstancias permitem, repele, de si ou de outrem, agressão atual e injusta, que não provocou, nem podia evitar sem humilhação ou perigo. $\S 10^{\circ}$ - A legítima defesa não se limita à proteção da vida e da integridade corporea; compreende todos os direitos que podem ser lesados, notadamente os relativos ao patrimônio, ao domicílio, à liberdade e à honra. § $20^{\circ}-$ A legitimidade da defesa regula-se pelo perigo inherente ao ato, pela natureza da lesão iminente e pelo modo do agir do agressor. 11 - Encontra-se em estado de necessidade aquele que infringir a lei penal para preservar um bem, seu ou de outrem, notadamente a vida, a integridade corporea, o patrimonio, liberdade e a honra, de dano relevante com que o ameace perigo atual, que não tenha voluntariamente provocado, nem de outra maneira pudesse evitar. § único 0 estado de necessidade não pode ser invocado por aquele que tinha o dever jurídico de expor-se ao perigo, por aquele de quem se pudesse razoavelmente exigir que suportasse o dano. $12-\mathrm{Em}$ todos os casos previstos neste capítulo aquele que se tiver excedido responderá pelo excesso, mas a pena poderá ser livremente atenuada. $\S 10^{\circ}$ - Tratandose de criminoso reincidente ou por índole, observar-se-á o disposto na parte final do § único do art. $5 .^{\circ}$ (aplicar-se-á a pena de acordo com a sua periculosidade). $\S 20^{\circ}$ - Quando o excesso no caso do art. 10 (legítima defesa) fôr excusavel pela surpresa da agressão ou pelo estado de excitação ou de medo, que ela tiver provocado no agredido, nenhuma pena se aplicará. $\$ 3 .^{\circ}-$ A pena não será tambem aplicavel quando. 
no caso do art. 11, as circunstancias do fato e as condições pessoais do inculpado excusarem o excesso.

Cons. 28 - A ordem de cometer o crime não isentará da pena aquele que o praticar, salvo se fôr cumprida em virtude de obediencia devida a superior legítimo e não houver excesso nos atos ou na forma da execução. 32 - Não serão .. criminosos: $\S 10^{\circ}$ - os que praticarem o crime para evitar mal maior; $\S 20^{\circ}$ - os que praticarem em defesa legítima própria ou de outrem. A legítima defesa não é limitada unicamente à proteção da vida; ela compreende todos os direitos que podem ser lesados. 33 - Para que o crime seja justificado no caso do $\S 10^{\circ}$.. deverão intervir conjuntamente a favor do delinquente os seguintes requisitos: $10^{\circ}$ certeza do mal que se propoz evitar; $20^{\circ}$ falta absoluta de outro meio menos prejudicial; $3 .^{\circ}$ probabilidade de eficacia do que se empregou. 34 - Para que o crime seja justificado no caso do $32 .^{\circ}$ deverão intervir conjuntamente em favor do delinquente os seguintes requisitos: $10^{\circ}$ agressão atual; $20^{\circ}$ impossibilidade de prevenir ou obstar a ação ou de invocar e receber socorro da autoridade publica; $30^{\circ}$ emprego de meios adequados para evitar o mal e em proporção da agressão; $4 .^{\circ}$ ausencia de provocação que ocasionasse a agressão.

\section{TITULO III}

\section{Do agente}

\section{Capítulo I}

\section{Da imputabilidade}

Art. 15 - Não são passiveis de pena, ficando, porém, sujeitos ás medidas de segurança constantes dos titulos $V$ e VI que lhes forem aplicaveis :

I - o menor de 18 anos;

II — o surdo-mudo não educado;

III - o selvícola não adaptado;

IV - aquele que, devido ao estado de alíenação mental, em que se encontre no momento do crime, fôr incapaz de compreender 
a criminalidade do fato ou de se determinar de acordo com essa apreciação.

Art. 16 - São passiveis de pena diminuida, ficando sujeitos. além disso, ás medidas de segurança constantes dos títulos $\nabla$ e $\nabla I_{\text {, }}$ que lhes forem aplicaveis:

I - o maior de 18 e menor de 21 anos;

II - o surdo-mudo educado;

III - o selvícola incompletamente adaptado;

IV - aquele que, devido a grave anomalia psíquica, de que não resulte alienação mental, tiver minorada sensivelmente no momento do crime, a capacidade de compreender a criminalidade do fato ou de se determinar de acordo com essa apreciação.

Art. 17 - Não autorizam nem a isenção, nem a diminuição. da pena:

I - os estados emotivos ou passionais;

II - a embriaguez pelo álcool ou substancia de efeitos análogos,. salvo se devida a caso fortuito ou força maior.

Pr. 18 - Não são passiveis de pena, mas sómente de medidas de segurança, os que carecerem de imputabilidade no momento de cometer a crime. 19: Carecem de imputabilidade aqueles que, por doença mental, desenvolvimento mental incompleto ou retardado, perda ou grave alteração da conciência, não possuirem a faculdade de normalmente determinar os proprios atos. Se esta faculdade, não estando abolida, estiverentretanto sensivelmente diminuida por alguma das causas acima especificadas, a imputabilidade será restrita. Carecem de imputabilidade os: menores de 16 anos. O Código dos Menores estabelecerá as condições em que o menor de 21 anos, será, ou não imputavel. 21: Os selvícolas e os surdos-mudos são inimputaveis, salvo quando adaptados ou instruidos, caso em que, consoante o grau da adaptação ou instrução, a sua impu-.. tabilidade poderá ser plena ou restrita. 22: A imputabilidade não é excluida nem diminuida por um estado voluntario e transitorio de inconciência ou de grave alteração da conciência produzido pelo alcool ou * por substâncias de natureza analgésica ou entorpecente. 23: A embriaguez devida a caso fortuito ou força maior, sendo plena, exclue, e, não sendo, diminue a imputabilidade. 24: A intoxicação crónica pelo alcool ou por substância de natureza analgésica ou entorpecente influe. sobre a imputabilidade para exclui-la ou diminui-la. 
Cons. 27 - Não são criminosos: $\S 10^{\circ}$ os menores de 14 anos; $\S 2 .^{\circ}$ os surdo-mudos de nascimento que não tiverem recebido educação nem instrução, salvo provando-se que obraram com discernimento; § 3. ${ }^{\circ}$ os que por imbecilidade nativa ou por enfraquecimento senil forem absolutamente incapazes de imputação; $\S 4 .^{\circ}$ os que se acharem em estado de completa perturbação de sentidos e de inteligência no ato de cometer o crime. 30: Os menores de 18 anos, abandonados e delinquentes ficam submetidos ao regime estabelecido pelo Código de Menores.

\section{Capítulo II}

\section{Da co-autoria}

Art. 18 - Incorrerão nas penas cominadas para o crime, com as modificações constantes dos arts. 19 e 20 :

I - quem o houver diretamente resolvido e executado;

II - quem tiver instigado ou determinado alguem a executá-lo;

III - quem executar o crime resolvido por outrem;

IV - quem, antes ou durante a execução, prestar auxilio, sem o qual o crime não seria cometido;

$\mathrm{V}$ - quem de outra maneira participar da preparação ou execução do crime.

$\S 10^{\circ}$ - Salvo expressa disposição em contrario, não serão puniveis, quando o crime não fôr cometido, o ajuste entre duas ou mais pessôas, ou a instigação para cometê-lo. Em qualquer desses casos, porém, poderá o juiz aplicar medida de segurança ao que participar do ajuste ou fizer a nstigação.

$\S 2 .^{\circ}$ - São incomunicaveis entre os partícipes:

I - as circunstancias pessoais de que resultem atenuação ou agravação do crime, ou isenção, diminuição ou aumento da pena.

II - as circunstancias reais de que o partícipe não tiver conhecimento, a menos que sejam elementos constitutivos do crime ou sirvam para lhe facilitar a execução.

$\S 3 .^{\circ}$ - No crime culposo, se o evento resultar da ação ou omissão de mais de um agente, cada um dêles ficará sujeito à pena estabelecida para o crime. 
Pr. 29 - Responde pelo crime, como se o houvera cometido, quem tiver determinado ou instigado o seu autor a comete-lo, para com ele concorrido ou á sua execução prestado assistencia. - $\mathrm{Na}$ co-autoria as relações, qualidades e circunstancias de caráter pessoal são incomunicaveis.

Cons. $17-$ Os agentes do crime são autores ou cumplices. 18: São autores: $\S 10^{\circ}-$ Os que diretamente resolverem a executarem 0 crime. $\$ 20^{\circ}-$ Os que, tendo resolvido a execução do crime, provocarem e determinarem outros a executa-lo por meio de dádivas, promessas, mandato, ameaças, constrangimento, abuso ou influencia de superioridade hierárquica. § $3 .^{\circ}-$ Os que, antes e durante a execução, prestarem auxilio, sem o qual o crime não seria cometido. $\S 4 .^{\circ}-$ Os que diretamente executarem o crime por outrem resolvido. 19: Aquele que mandar ou provocar alguem a cometer crime é responsavel como autor: § 1. $^{\circ}$ por qualquer outro crime que o executor cometer no executar o de que se encarregou. $\S 2 .^{\circ}$ por qualquer outro crime que daquele resultar. 20: Cessará a responsabilidade do mandante se retirar a tempo a sua cooperação no crime. 21: São cumplices: $\S 10^{\circ}$ Os que, não tendo resolvido ou provocado de qualquer modo o crime, fornecerem instruções para comete-lo e prestarem auxilio à sua execução. $\$ 2^{\circ}$ Os que, antes ou durante a execução, prometerem auxilio as criminoso para evadir-se, ocultar ou destriur os instrumentos do crime ou apagar os seus vestigios. $\$ 3 .^{\circ}$ Os que receberem, ocultarem ou comprarem cousas obtidas por meios criminosos, sabendo que o foram, ou devendo sabe-lo, pela qualidade ou condição das pessoas de quem as houverem. $\S 4 .^{\circ}$ Os que derem asilo ou prestarem sua casa para reunião de assassinos e roubadores, conhecendo-os como tais e o fim para que se reunem.

Art. 19 - A pena será aumentada:

I - para quem promover ou organizar a cooperação no crime ou dirigir a atividade dos partícipes;

II - para quem instigar ou determinar a cometer o crime (art. 18 n. II) pessoa sujeita a sua autoridade, ou não punivel em virtude de condição ou qualidade pessoal;

III - para quem houver querido participar de crime mais grave do que o cometido, não devendo, porém, a pena imposta exceder o máximo da cominada para o primeiro.

IV - para quem houver executado o crime, no caso do art. 18 n. III, mediante paga ou promessa de recompensa.

Pr. - Cmisso.

Cons. - Omissa. 
Art. 20 - A pena será diminuida :

I - para quem, no caso do art. 13 n. $\nabla$, tiver participação de somenos importancia na preparação ou execução do crime;

II - para quem houver querido participar de crime menos grave do que cometido; não podendo, porém, a pena imposta ser inferior ao mínimo da cominada para aquele.

Pr. 100 - Fixando a pena atenderá o juiz .. à importancia de sua participação no crime.

Cons. - Omissa.

\section{CaPitulo III}

\section{Dos criminosos ocasionaes, por tendencia, reincidentes e habituaes}

Art. 20 - Haver-se-á como criminoso ocasional aquele que tiver cedido exclusivamente a uma influencia exterior e momentanea, constituindo fato singular em sua vida o crime cometido.

Pr. 42 - 0 criminoso primario será punido como criminoso momentaneo .. quando não acusar tendências a delinquir, ou preponderarem as influências exteriores que o tiverem propelido ao crime.

Cons. - Omissa.

Art. 21 - Haver-se-á como criminoso por tendencia aquele que demonstrar notavel perversão moral, por seu comportamento anterior, concomitante ou subsequente a um crime doloso de perigo comum ou contra a integridade pessoal ou a vida. Não se haverá, todavia, como tal quem tiver cometido o crime nas condições do art. 16 n. IV.

Px. 42 - 0 criminoso prinário será punido .. I - como criminoso momentaneo, quando não acusar tendência a delinquir, ou preponderarem as influências exteriores que o tiverem propelido ao crime; II - como criminoso por índole, quando pela perversidade da concepção ou atrocidade da execução, a tendência a delinquir preponderar sôbre as influências exteriores.

Cons. - Omissa. 
Art. 22 - Haver-se-á como criminoso reincidente aquele que cometer novo crime depois de condenado no Brasil ou no estrangeiro por sentença passada em julgado.

$\S 10^{\circ}$ - Diz-se especifica a reincidencia, quando os crimes são da mesma natureza, porque infringem a mesma disposição legal ou porque, infringindo disposições diferentes, apresentam os mesmos carateres fundamentaes nos atos que os constituem ou nos motivos que os determinam.

$\S 20^{\circ}-$ Diz-se genérica a reincidencia, quando os crimes são de natureza diferente.

$\S 30^{\circ}$ - Diz-se reiterada a reincidencia, quando, depois de reconhecido reincidente por sentença irrevogavel, o agentè é condènado por novo crime.

$\S 4 .^{\circ}$ - Poderá o juiz, atentas as condições do agente, não reconhecer a reincidencia genérica :

I - se um dos crimes fôr doloso ou preterintencional e o outro culposo;

II - se um dos dêles fôr comum e o outro exclusivamente militar ou político-social.

Pr. 40 - Aquele que, já tendo sido condenado, no país ou no estrangeiro, por sentença passada em julgado, cometer novo crime, será punido como reincidente, quando acusar tendência a delinquir. § único. Não se terá em conta na reincidência: I - a condenação extinta pela anistia. II - a infligida por crime político-social ou exclusivamente militar, tratando-se de crime comum; III - a infligida por crime culposo ou contravenção, salvo se a nova infração fôr da mesma natureza; IV - a que constar de sentença extinta por efeito de livramento condicional, da suspensão da pena e da rehabilitação; V - a que constar de sentença estrangeira por crime que, segundo a lei brasileira, não admite a extradição.

Cons. $39 \S 19$ - São circunstancias agravantes ter o delinquente reincidido. 40 - A reincidência verifica-se quando o criminoso, depois de passado em julgado sentença condenatoria, cometa outro crime da mesma natureza, e como tal entende-se para o efeito da lei penal o que consiste na violação do mesmo artigo. Sofre exceção esta regra no caso do art. 178 (crimes eleitorais).

Art. 23 - Haver-se-á como criminoso habitual aquele: 
I - que, depois de condenado, no Brasil ou no estrangeiro a penas privativas da liberdade, por tres ou mais crimes dolosos ou preterintencionaes, praticados em épocas diferentes, cometer novo crime não culposo, punido com prisão ou detenção, dentro dos dez anos seguintes á data do último dos crimes precedentes;

II - ou que, depois de sentenciado, no país ou fóra dêle, a penas privativas da liberdade, por dois erimes dolosos ou preterintencionaes da mesma natureza, praticados em épocas diversas, cometer novo crime de natureza idêntica, punido com prisão ou detenção, dentro de cinco anos contados na fórma do inciso anterior;

III - uma vez que, não só pelo número, natureza, circunstancias e pequeno intervalo entre os crimes cometidos, como peio genero de existencia, que tiver levado nesse tempo, o agente, se mostre avezado ao crime ou inclinado a viver, ainda que só em parte, dos proventos de soa atividade criminosa.

$\S 10^{\circ}$ - Nos prazos de 10 e 5 anos, a que se referem os ns. I e II, não se computará o tempo em que o agente houver cumprido penas privativas da liberdade ou medidas detentivas de segurança.

$\S 20^{\circ}-$ Aplicar-se-á o disposto neste artigo ainda que a condenação do agente pelos vários crimes conste de uma única sentença.

Pr. 41 - 0 reincidente será punido como profissional, quando habitualmente viver dos proventos do crime ou dele fizer fonte ordinária de renda .... como icorrigivel, quando pela terceira vez fôr condenado, ..... como criminoso por índole, quando, sobre as circunstancias exteriores que possam ter influido na prática do crime, decisivamente preponderar a tendência a delinquir já verificada por ocasião do crime anterior.

Cons. - Omissa.

Art. 24 - Para o reconhecimento da reincidencia e a declaração da habitualidade computar-se-á a condenação extinta em virtude de causa extintiva do crime ou da pena, que não importe na extinção de todos os efeitos da sentença.

Cons. - Omissa.

Pr. - Omisso. 
Art. 25 - 0 reconhecimento da reincidencia e a declaração da habitualidare e da tendência a delinquir são materia da competencia do juiz, e fazem-se na sentença condenatoria.

$\S 10^{\circ}$ - A da habitualidade, todavia, poderá ser feita, a requerimento do Ministerio Publico, pelo juiz da execução, e ainda que já esteja cumprida a pena, quando tiver deixado de fazê-la a sentença condenatoria. Neste caso, porém, não se levará em conta o comportamento posterior do condenado, nem sofrerá modificação a pena infligida.

$\S 2 .^{\circ}$ - Da sentença declaratoria da tendência a delinquir e da habitualidade, proferidas em primeira instancia, haverá apelação ex-oficio.

§ $3 .^{\circ}$ - Só produzirá efeito a sentença, quando, por dois terȩos de votos, fôr proferida ou confirmada pelo tribunal superior.

$\S 4 .^{\circ}$ - A declaração da tendência a delinquir ou da habitualidade :

I - terá, além dos efeitos constantes de outros dispositivos legais, a de sujeitar o agente à aplicação de medidas de segurança;

II - ficará extinta em consequência da rehabilitação.

Pr. 40 § único - (já transcrito) diferente.

Cons. - Omissa.

TITULO IV

\section{Das penas}

\section{Capitulo I}

\section{Das varias especies de pena}

Art. 26 - São as seguintes as penas cominadas por este Código:

$$
\begin{aligned}
& \text { I - morte; } \\
& \text { II - reclusão; } \\
& \text { III - detenção; } \\
& \text { IV - segregação; } \\
& \text { V - multa. }
\end{aligned}
$$


Pr. 49 - As penas cominadas neste Código são principais ou acessorias. 50:São penas principais a multa, o exilio local, a detenção, a prisão, a relegação.

Cons. 43 -- As penas estabelecidas são as seguintes: prisã ocelular, prisão correcional, reclusão, com trabalho obrigatório, prisão disciplinar, interdição, suspensão e perda de emprego público, com ou sem inhabilitação para exercer outra, multa.

\section{SECĢão I}

\section{Da pena de morte}

Art. 27 - Não se aplicará a pena de morte:

I - quando o condenado fôr menor de 21 anos ou maior de 70;

II - quando a única prova de qualquer dos elementos constitutivos do crime fôr a confissão do agente;

III - quando militarem em favor do agente uma ou mais circunstancias atenuantes ou uma causa de diminuição da pena;

IV - quando não forem unânimes a sentença que impuzer a pena e a sentença que a confirmar.

$\S 10^{\circ}-\mathrm{Da}$ sentença que impuzer a pena de morte haverá recurso necessario.

$\S 20^{\circ}-$ Verificada qualquer das hipóteses previstas neste dispositivo, aplicar-se-á a pena de reclusão por 30 anos, sem prejuizo do que dispõe, quanto aos menores de 18 a 21 anos, o art. 117.

Art. 28 - Não se dará execução á peṇa de morte:

I - enquanto pendente de decisão o pedido de graça;

II - em domingo ou feriado năcional.

Art. 29 - A pena executar-se-á mediante fuzilamento, dentro do estabelecimento penal onde se encontre o condenado, e no dia seguinte ao em que este fôr intimado da sentença irrevogavel ou da denegação do pedido de graça.

$\S 10^{\circ}-O$ ato não será público. 0 condenado poderá, entretanto, ser assistido até ao derradeiro instante pelo ministro do culto, cujo auxilio tiver solicitado ou aceito.

§ 2. -0 juiz fará constar a execução de termo nos autos, que será publicado juntamente com a sentença condenatoria. 
$\S 3 .^{\circ}$ - Entregar-se-á o cadaver do executado a qualquer dos parentes até ao segundo grau, inclusive, que o reclamar do juiz.

Pr. 49 - Contrario.

\section{SecÇão II}

\section{Das penas privativas da liberidade}

Art. 30 - A pena de reclusão é no mínimo de 1 ano e de 30 anos no máximo, salvo expressa disposição em contrário.

Pr. 64 - Salvo disposição em contrắrio, expressa na parte especial e conversão prevista no art. 61, a pena de prisão terá por mínimo 1 ano e por máximo 30.

Cons. 44 - As penas restritivas da liberdade individual são temporárias e não excederão de 30 anos.

$\S 10^{\circ}$ - A pena de reclusão cumpre-se em penitenciária ou, na falta desta, em seçã̃o especial de prisão comum.

$\S 20^{\circ}-\mathrm{A}$ reclusão comporta :

I - um período inicial de isolamento diurno e noturno, não menor de 15 dias, nem maior de 3 meses, o qual, entretanto, poderá ser dispensado ou restringido pelo juiz, atentas as condições de sexo, idade ou saúde do sentenciado;

II - um periodo subsequente de trabalho obrigatório dentro do estabelecimento ou fóra dêle, ao ar livre, em obras ou serviços públicos, com isolamento noturno, e, se fôr o caso, instrução primária ; periodo que se prolongará até ao cumprimento da metade da pena, e que, se a duração da pena o comportar, não será inferior a 2 anos;

III - e, quando o autorize o bom comportamento do sentenciado durante a vida penitenciária, um último periodo em que ficará sujeito às mesmas obrigações dos anteriores, podendo, porém, ser transferido para um estabelecimento penal, onde lhe seja permitido cultivar lotes de terra por conta própria. 
Pr. 65 - Cumpre-se a pena de prisão: $10^{\circ}$ - nas penitenciárias, e prisões comuns destinadas aos imputaveis; $2 .^{\circ}$ - nos estabelecimentos especiais destinados aos criminosos de imputabilidade restrita, que só o cumprirão nos comuns quando aqueles não existirem; $6 .^{\circ}-$ a execução simples ..... obedecerá ... isolamento celular diurno por 2 meses e isolamento noturno durante a execução ..... direito à correspondência .... visita nos dias regulamentares .. livros ... não adstrito à segregação nos intervalos, nem ao isolamento no recreio $\ldots 1^{\circ} \quad \ldots$ vestirá uniforme regulamentar e alimentar-se-á da cosinha ... podendo 1 vez por semana .. de fóra. $\S 2 .^{\circ}$ Consoante o comportamento .. as concessões ... restringidas ou provisoriamente suprimidas. $\S 30^{\circ}$ Obrigatória a incomunicabilidade entre ... prisão rigorosa e prisão simples. 68 Quando o sentenciado .. novo crime ... a sua execução será rigorosa. 59 - A execução rigorosa começará .. segregação celular de 6 meses, prorrogavel por mais $3 \ldots 70$ - Durante a segregação $\ldots 1$ hora de ar livre todos os dias .. não se poderá corresponder por escrito senão com juiz, M. P. ou patronato; nem comunicação diréta senão pessoal estabelecimento; não ... visitas, salvo em clomingos, a sacordote .. alimentar-se-á da cosinha .. salvo prescrição médica. 71 - Concluido o periodo de segregação, começará o de trabalho em comum, com isolamento, intervalos e repouso à noite. $\S 10^{\circ}$ - Salvo proibição médica .. adstrito ao trabalho. $\S 2 .^{\circ}-$ No $10^{\circ}$ ano ... trabalho no interior ou dependencias - Do $2 .^{\circ} \mathrm{em}$ diante, poderá ... ar livre, obras e serviços públicos. § 2.0 Para obras e serviços fóra ... não se escalará sentenciado que nêle tiver ocupação ajustada às suas aptidões, salvo quando preferir ou ... medida disciplinar. 72 - Cumprida por metade a pena, poderá o. juiz, converter em simples a rigorosa, precedendo inquérito ... Esta concessão é irrevogavel a todo o tempo ...

Cons. 45 - A pena de prisão celular será cumprida em estabelecimento especial, com isolamento celular e trabalho obrigatorio, observadas as seguintes regras: a) de não exceder a um ano, com isolamento celular pela quinta parte de sua duração; b) de exceder desse prazo, por um período igual à quarta parte da duração da pena e que não poderá exceder a dois anos, e, nos períodos sucessivos, com trabalho em comum, segregação noturna e silencio durante o dia.

Art. 31 - A pena de detenção é no mínimo de 6 dias, salvo. - caso de conversão de multa, em que pode ser inferior, e no máximo de 3 anos, salvo expressa disposição em contrário.

$\S 10^{\circ}$ - A pena de detenção:

I - aplica-se especialmente ao criminoso ocasional; 
II - converte-se na de reclusão por igual tempo, em se tratando de criminoso reincidente, habitual ou por tendência.

$\S 2 .^{\circ}-$ Cumpre-se a pena de detenção em estabeleciménto destinado a esse fim, e, na falta dêle, em seçã̃o especial de renitenciária ou de prisão comum.

$\S 3 .^{\circ}-\mathrm{O}$ sentenciado ficará sujeito a isolamento noturno e trabalho obrigatório; mas

I - não será empregado em obras ou serviços públicos fóra do estabelecimento;

II - será aproveitado, quando possivel, em trabalhos diversos dos que se executem no estabelecimento, atentas as suas aptidões $\epsilon$ ocupações anteriores.

$\S 40^{\circ}$ - Poderá o juiz permitir que o sentenciado cumpra em seu domicilio, sob vigilância, a pena de detenção, dado o concurso das seguintes condições:

I - ser a pena por tempo não superior a um mês;

II - tratar-se de valetudinário, ou de mulher honesta, que nenhuma periculesidade apresentem.

Pr. 62 - A pena de detenção, salvo disposição expressa em contrario terá por mínimo 5 dias e por máximo 3 anos; aplica-se especialmente a criminosos primarios e será convertida em prisão, quando aplicada aos que a compreendem na classificação dos arts. .. ou quando os moveis forem vís. - Cumpre-se a pena de detenção em estabelecimento especial ou, este não existindo, na penitenciária, em secção exclusivamente destinada ao seu cumprimento. $\S 10^{\circ}$ - Onde não existir penitènciária, ela se cumprirá em lugar separado daquele em que, na cadeia pública, se cumprir a pena de prisão. $\S 20^{\circ}$ - Tendo em vista as circunstancias do fato e as condições do condenado, poderá o juiz determinar que a pena de detenção, não excedente de 1 mês, se cumpra em casa. 63 - No cumprimento da pena de detenção, onde houver estabelecimento especial ou penitenciária ... o condenado será adstrito ao trabalho, mas poderá escolher, dentre os que se executarem no estabelecimento, o que melhor lhe convenha se não preferir trabalhos intelectuais a que já esteja afeito; não se lhe poderá impôr trabalhos ao ar livre em serviços públicos; o isolamento celular diurno .. só aplicável como medida disciplinar ... não estará sujeito ao vestuário regulamentar e poderá fazer vir de fóra a alimentação, excluidas as bebidas alcoólicas; poderá receber visitas ... 
escrever e receber cartas .. § único: Consoante o comportamento ... as concessões ... poderão restringidas ou provisoriamente suprimidas.

Cons. 46 - A pena de prisão correcional será cumprida em colórias .. para a rehabilitação pelo trabalho e instrução, de mendigos válidos, vagabundos e vadíos, capoeiras e desordeiros. $47-\mathrm{A}$ de reclusão ... em fortalezas, praças de guerra ou fortalezas militares. 48 - A de prisão com trabalho em penitenciárias agrícolas ... ou presidios militares. 53 - Ao condenado será dado ... trabalho adaptado às suas habilitações e precedentes ocupações.

Art. 32 - As penas privativas da liberdade, aplicaveis aos maiores de 18 anos, nos termos do art. 16, converter-se-ão na de segregação por igual tempo, a ser cumprida:

I - pelos selvícolas incompletamente adaptados, em secção especial de instituto de trabalho obrigatorio;

II - pelos portadores de grave anomalia psíquica e pelos surdos-mudos incompletamente educados, em seções especiais de casa de tratamento e custodia.

$\S$ único - Verificado a cura, no primeiro caso do n. II, ou, no segundo, terminada a educação, poderá o juiz, ouvindo peritos, determinar que o restante da pena seja cumprida em estabelécimento comum.

Pr. - Omisso, quanto aos surdos-mudos e selvícolas. Diferente (medida de segurança e pena), quanto aos outros.

Cons. - Omissa.

Art. 33 - As mulheres cumprirão as penas privativas da liberdade em estabelecimentos distintos, ou, onde não os houver, em secções distintas dos estabelecimentos destinados aos homens.

§ único - Só no estabelecimento e suas dependências e em ocupações adequadas ao sexo, as condenadas serão obrigadas ao trabalho.

Pr. - Omisso.

Cons. - Omissa.

Art. $34-0$ trabalho dos sentenciados: 
I - organizar-se-á de maneira a atender ás suas necessidades higiênicas a aperfeiçoar a sua capacidade profissional;

II - não excederá, salvo o caso de força maior, de 44 horas por semana;

III - será justamente remunerado.

$\S 10^{\circ}$ - Um terço da remuneração constituirá premio impenhorável do sentenciado, que lhe será entregue, de uma só vez ou parceladamente, conforme as circunstancias, uma vez cumprida a pena ou concedido o livramento condicional.

§ 2. - 0 restante dividir-se-á em partes iguais destinadas:

I - a indenizar ao poder público as despesas de manutenção do sentenciado;

II - a reparar o dano que de outro modo não o tiver sido;

III - a satisfazer os alimentos de que o sentenciado seja devedor na fórma da lei civil;

IV - a pagar as custas e despesas judiciais.

$\S 3 .^{\circ}$ - Se não couber a aplicação de qualquer das parcelas especificadas nos dois últimos incisos do $\S$ anterior, a respectiva importancia acrescerá à destinada à reparação do dano; e, se este já estiver reparado, dividir-se-á igualmente entre o Estado, para a indenização das despesas de manutenção, e o sentenciado, para a formação do peculio.

Pr. 73 - O trabalho do sentenciado será sempre remunerado, e o seu salario constituirá dívida do Município, do Estado ou da União, regulando-se pelo do operario livre, menos um terço. 0 salario do sentenciado dividir-se-á em 3 partes, das quais uma entrará para os cofres públicos como receita, outra será entregue à vitíma ou aos seus herdeiros, por ordem do juiz, e a $3 .^{a}$ restante constituirá peculio do sentenciado, e será levada à sua caderneta especial. 74 - Cumprida a pena, ou concedido o livramento condicional, ao sentenciado será entregue o peculio, revertendo aos cofres públicos a parte destinada à vítima ou seus herdeiros que não tiver sido reclamada.

Cons. - Omissa.

Art. 35 - Os regulamentos dos estabelecimentos destinados à execução das penas detentivas não podem autorizar medidas disciplinares que ofendam a saúde ou a dignidade humanas, ou que reduzam a remuneração do trabalho do sentenciado. 
§ único - A reclusão celular absoluta não será imposta, como medida disciplinar, por tempo maior de 30 dias, nem privará o sentenciado de trabalhar, quando possivel, na própria célula.

Pr. - Omisso.

Cons. - Omissa.

Art. 36 - As penas privativas da liberdade poderão ser cumpridas nos estabelecimentos comuns ou especiais de Estado diferente ou da União, mediante acordo entre os respectivos governos.

Pr. 66 - Qualquer que seja a justiça que a impuzer, a pena poderá ser indiferentemente cumprida nas penitenciárias ou prisões da União ou dos Estados, mediante acordo entre os respectivos governos.

Cons. 409 - Enquanto não entrar em inteira execução o sistema penitenciário, a pena de prisão celular será cumprida, como a de prisão com trabalho, nos estabelecimentos penitenciários, segundo o regime atual.

Art. 37 - Computar-se-ão na pena privativa da liberdade :

I - o tempo da prisão preventiva no Brasil ou no estrangeiro;

Ii - o tempo da internação em hospital.

Pr. 117 - 0 tempo da detenção preventiva e o do internamento em hospital ou hospicio, quando não fôr este obtido por fraude ou simulação, será computado na pena.

Cons. $60-$ Não se considera pena $\ldots$ a prisão preventiva ... a qual, todavia será computada na pena legal. 65 §único - Se a enfermidade (loucura) manifestar-se depois que o condenado estiver cumprindo a pena, ficará suspensa a sua execução, não se computando o tempo da suspensão no da condenação.

Art. 38 - Não se dará inicio á execução da pena privativa da liberdade:

I - enquanto não se restabelecer o condenado, a que houver sobrevindo doença mental;

II - enquanto perdurar a gravidez da condenada ou não decorrerem seis meses sôbre a data do parto;

III - enquanto não se revogar a sentença de execução condicional.

$\S 10^{\circ}-\mathrm{Na}$ primeira hipótese o condenado será internado em manicômio judiciário; podendo, entretanto, o juiz determinar que - seja em manicomio comum, se o tempo da pena não excedert de 
tres anos e não se tratar de criminoso reincidente, habitual ou por tendência.

$\S 2 .^{\circ}-\mathrm{Na}$ segunda, o prazo ficará reduzido a 40 dias, se o filho morrer ou fôr confiado a outra pessôa; e poderá ter ampliado até um ano, se não houver como confiar a outrem a creança.

Pr. - Omisso.

Cons. - Omissa.

Art 39 - Interromper-se-á a execução da pena privativa da liberdade :

I - quando ao sentenciado sobrevier doença mental, que obrigue a sua hospitalização, caso em que se procederá de acordo com o $\S 10^{\circ}$ do artigo precedente;

II - quando o sentenciado obtiver livramento condicional.

Pr. 115 - As penas privativas da liberdade são de execução ininterrupta, salvo caso de força maior e as exceções previstas neste Código. 116 - $O$ juiz da execução, mediante parecer médico e audiência do $M$. P., poderá por motivo de saúde: I - interromper a execução da pena por prazo certo, mas prorrogavel, internando o condenado em hospital ou hospicio, ressalvada a segurança social; II - abrandar a execução, de modo a torná-la compativel com o estado de saúde do condenado.

Cons. $68-0$ condenado que achar-se em estado de loucura só entrará em cumprimento da pena quando recuperar as suas faculdades intelectuais. § único: Se a enfermidade manifestar-se depois que o condenado estiver cumprindo a pena, ficará suspensa a sua execução, não se computando o tempo da suspensão no da condenação.

\section{SECÇão III}

\section{Da pena de multa}

Art. 40 - Impor-se-á a pena de multa :

I - quando expressamente cominada:

II - quando a cobiça tiver sido o motivo determinante do crime, aplicando-se então a multa cumulativamente com a pena de outra natureza que na espécie a lei cominar.

$\S 1 .^{\circ}$ - A sentença que impuzer a pena de multa fixar-lhe-á - impôrtancia e marcará o prazo em que deve ser paga ao Tesouro 
Nacional, tudo de acôrdo com as condições econômicas do condenado e a maior ou menor gravidade do crime.

§ $2 .^{\circ}$ - A importância da multa não será inferior a 50\$000, nem superior a $100: 000 \$ 000$, salvo:

I - quando, por lei, a multa consistir em percentagem sôbre determinado valor, hipótese em que nenhum limite se admitirá;

II - quando a situação econômica do condenado autorizar a certeza de que, embóra aplicada no máximo acima estabelecido, a multa não será eficaz, hipótese em que o juiz poderá aumentá-la até ao triplo;

III - quando se tratar de reincidência específica, hipótese em que, se não fôr substituida por outra pena mais grave, a multa será aumentada até $20 \%$ da condenação anterior.

§ $3 .^{\circ}-\mathrm{A}$ execução da pena de multa ficará suspensa, enquanto não se restabelecer o condenado a que tiver sobrevindo doença mental.

Art. 41 - A multa incobrável por motivo de insolvência converter-se-á, à razão de $1.0 \$ 000$ por dia, em detenção até 18 mêses.

$\S 10^{\circ}$ - Não prevalecerá, nêste caso, o limite mínimo estabelecido no art. $40 \S 2 .^{\circ}$.

$\S-2 .^{\circ}$ - Descontar-se-á, na mesma rażão de $10 \$ 000$ por dia, o tempo da prisão preventiva.

$\S 3 .^{\circ}-$ A conversão ficará sem efeito, uma vez que o condenado satisfaça o que estiver devendo a título de multa ou lhe garanta com fiança idónea ou garantia real o pagamento.

Art. 42 - A requerimento do condenado poderá o juiz:

I - autorizar o pagamento em prestações periódicas, distribuidas de maneira que aquele se complete em prazo não maior de 18 mêses;

II - permitir o pagamento, mediante a prestação de serviços em obras ou estabelecimentos públicos, reservado do salário quanto baste à mantença do condenado e a seus encargos de família. 
Pr. 53 - A multa consiste em certa quantia que fixa o juiz e o condenado paga ao Município, ao Estado ou à União. 1. ${ }^{\circ}$ - Para aplicá-la tomará o juiz por ponto de partida uma unidade artificial que será o dia-multa. $§ 2 .^{\circ}$ - Na fixação do dia-multa considerar-se-á toda a renda mensal, ou anual do infrator, dela deduzindo-se o que razoavelmente baste à sua manutenção e à família. A diferença líquida restante será dividida por 30 , ou por 365 dias, conforme se haja considerado a renda por mês, ou por ano, e o quociente indicará o dia-multa. $\S 30^{\circ}-$ Assim fixado o dia-multa, será o mesmo multiplicado por tantas unidades - de um a duzentos - quantas parecer ao juiz corresponderem à gravidade de infração cometida, e o resultado exprimirá em mil réis a multa aplicável. $\S 60^{\circ}-0$ juiz requisitará as informações e procederá às diligencias necessárias à verificação da renda do infrator, mas se absterá de medidas que importem devassa. 56 - Mesmo, porém, que não comine (a lei), a multa, como pena acessoria, será imposta ao infrator que tiver agido por espírito de ganancia, cobiça ou avareza. 53. - Não se executará a multa contra aquele que não puder solvê-la, sem contar pelo indisindispensàvel à própria subsistencia $\mathrm{e}$ dos seus, mas, não estando prescrita a todo o tempo será cobrada, sobrevindo a solvência. $\mathrm{Na}$ reincidência as multas se cobrarão por junto, regulando-se pela da última a prescrição das anteriores. $\S 10^{\circ}-$ Ao que se não- puderem- quitar de uma só vez, permitirá o juiz fazê-lo por parcelas em prazos razoáveis, cujo total, porém, não poderá exceder de 1 ano. $\xi 20^{\circ}$ - Se, após a sentença, os recursos do condenado sensivelmente diminuirem, poderá o juiz reduzir a multa, suavizar as prestações e dar maior espaço ao pagamento. $\S 3 .^{\circ}-0$ pagamento da multa poderá ser feito prestação de trabalho livre por conta de particulares, no Município, no Estado ou na União, provendo o juiz de maneira que o salário ganho se aplique simultareamente, ao pagamento da multa e à subsistência do condenado e sua família. $\S 4 .^{\circ}$ - Os móveis, roupas e utensílios indispensáveis à vida doméstica do condenado, assim como os instrumentos de sua profissão ou trabalho, não rešpondem pela multa.

Cons. 58 - A pena de multa consiste no pagamento ao Tesouro Público Federal ou dos Estados, segundo a competência respectiva, de uma soma pecuniária, que será regulada pelo que o condenado puder ganhar em cada dia, por seus bens, emprego, indústria ou trabalho. 59 - Se o condenado não tiver meios para pagar a multa ou não puder pagar dentro de 8 dias, contados da intimação judicial, será convertida em prisão celular, conforme se liquidar. $\S$ único $-\mathrm{A}$ corversão da multa em prisão ficará sern efeito se o criminoso, ou alguem por êle, satisfizer ou prestar fiança idônea ao pagamento da multa. 


\section{Capítulo il}

\section{Da aplicação da pena}

Art. 43 - Compete ao juiz, fundamentando cumpridamente a decisão :

I - determinar a qualidade da pena aplicavel, quando a lei estabelecer alternativamente mais de uma;

II - determinar, dentro dos limites legaes, a quantidade da pena aplicavel.

$\S$ único - No exercicio desses poderes o juiz atenderá:

I - á personalidade do agente;

II - ás circunstancias que agravam ou atenuam o crime;

III - ás causas de aumento e diminuição da pena.

Art. 44 - Para formar juizo sobre a personalidade do agente, o juiz terá em conta :

I - a idade, educação e situação econômica do réo, os seus antecedentes judiciais ou penais e procedimento na vida individual, familiar e social;

II - o seu comportamento e estado de ânimo antes, durante e depois do crime;

III - quaesquer outros elementos que contribuam para o conbecimento de seu temperamento e caráter.

Pr. 99 - Aplicando a pena estará adstrito o juiz ao mínimo e ao máximo específicos e sómente poderá transpôr nos casos expressamente determinados. Na falta de especificação regular-se-á pelo mínimo e máximo genéricos. Quando tiver de aplicar, aumentada ou diminuida, pena cominada em outro artigo, o aumento ou diminuição se fará tendo em vista o juiz a pena concreta aplicavel. 190 - Fixando a pena atenderá o juiz: 1) à personalidade do criminoso, ao perigo social que ele exprima, à categoria em que o deva classificar; 2) aos motivos que o determinaram; 3) à importancia de sua participação no crime; 4) à gravidade deste e à comoção social que tiver provocado; 5) ao dano causado, material ou moral.

Cons. - Omissa. 
Art. 45 - São circunstancias que agravam o crime, quando não o constituem ou qualificam, tê-lo cometido o agente :

I - não obstante a previsão do evento, em se tratando de crime culposo;

II - por motivo fútil ou torpe;

III - para facilitar a ezecução ou ocultação de outro, ou para conseguir ou assegurar, em beneficio próprio ou alheio, a impunidade ou os proventos de crime diverso;

IV - depois de se embriagar propositadamente para cometer o crime;

$\mathrm{V}$ - com a agravação ou tentativa de agravação dos sofrimentos do ofendido ou de outras consequências do fato;

VI - à traição, com disfarce, mediante emboscada ou em outras condições de tempo, lugar ou pessôa, que tenham impossibilitado ou dificultado a defêsa do ofendido;

VII - com o emprego de tóxico, sevicias ou outros meies insidiosos ou cruéis;

VIII - contra funcionário público ou ministro de culto reconhecido pelo Estado, ou agente diplomático ou consular de nação estrangeira, no ato ou em consequência do desempenho das respectivas furções;

IX - com abuso dos poderes ou infração dos deveres inherentes do exercício de função pública, ministério religioso, pátrio poder, autoridade marital, tutela, curatela ou profissão;

$\mathbf{X}$ - contra pessoa a cuja guarda, vigilancia ou autoridade estiver sujeito.

Pr. 104 - A pena será aumentada quando: 1) os moveis do crime foram vis; 2) se tratar de criminoso por indole, reincidente, incorrigivel ou profissional; 3) o criminoso se tiver deliberadamente embriagado para cometer o crime; 4) tiver agido com premeditada surpreza, engano, simulação ou fraude; 5) não tiver reparado o mal, podendo fazê-lo; 6) neste Código se ordena expressamente a agravação.

Cons. 39 - São ... agravantes: 1) de noite ... em logar ermo ... 2) premeditação .. 3) veneno, substancias anestésicas, incendio, asfixia ou inundação; 4) é motivo reprovado ou frivolo ... 5) superioridade em sexo, força ou armas; 6) fraude ou abuso de confiança; 
descendente, conjuge, irmão, mestre, discipulo, tutor, tutelado, amo, domestico ou legítimo superior ou inferior; 10) paga ou promessa de recompensa; 11) arrombamento, escalada ou chaves falsas; 12) entrada ou tentativa para entrar em casa do ofendido; 13) ajuste; 14) em auditorios de justiça, casa ou reuniões públicas ou repartições; 15) desrespeito à idade ou enfermidade do ofendido; 16) estando o ofendido sob a imediata proteção da autoridade; 17) emprego de diversos meios; 18) em ocasião de incendio, naufragio, inundação, qualquer calamidade ou desgraça particular do ofendido; 19) reincidencia.

Art. 46 - São circunstancias que atenuam o crime, quando não o constituem ou qualificam:

I - ter sido ele cometido por motivo de reconhecida nobreza;

II - ou sob o influxo de violenta emoção provocada por ato injusto de outrem;

III — ou sob a influencia de assembléa ou multidão em tumulto, uma vez que não se trate de reunião ou ajuntamento ilícitos, e que o agente não tenha provocado o tumulto, nem seja criminoso reincidente, habitual ou por tendencia;

IV - ter concorrido para o evento fato culposo de outrem ou outra causa estranha á vontade do agente;

$\mathrm{V}$ - ter o agente conseguido, de motu proprio, logo depois de cometido o crime, evitar-lhe ou minorar-lhe as consequencias; ou haver, antes do julgamento, reparado espontanea e integralmente c dano;

VI - ter-se o agente apresentado á autoridade e confessado o crime, impelido pelo arrependimento, quando a autoria seja ignorada ou imputada a outrem.

Pr. 101 - A pena será diminuida quando: 1) o crime se originar de sentimentos bons; 2) o criminoso fôr momentaneo ou ilibado tiver sido a sua vida anterior; 3) crise moral profunda ou, em culpa sua, situação angustiosa o empolgava; 4) tiver cedido á piedade, provocada por situação irremediavel de sofrimento em que se encontrasse a vítima. e ás suas súplicas; 5) sem culpa acidentalmente se tiver embriagado; 6) dominado pela cólera ou desvairado pela dor, produzidas por injusta provocação ou imerecida ofensa; 7) da juventude ou velhice se puder legitimamente concluir-se incompleta a sua formação moral ou que a idade a desintegra; 8) sob a influencia da multidão em tumulto; 9j 
inceramente acreditava estar praticando ato lícito; 10) sob o temor de ;rave ameaça; 11) sob a pressão da obediencia natural ou da dependencia; .2) para o resultado houver concorrido ato internacional do ofendido iu somente por condições personalissimas deste, que o ofensor ignorasse - resultado se tiver produzido; 13) tiver reparado o dano material ou noral causado pelo crime, ou se esforça por fazê-lo nas medidas de iuas posses; 14) pelo mesmo crime já tiver no estrangeiró cumprido sena que, por diferente, se não possa imputar na que fôr imposta; 15) gnorada a autoria, por impulso de arrependimento se apresentar á ustiça e confessar o crime; 16) o prazo da prescrição estiver prestes 1 expirar e durante o seu curso tiver mantido o criminoso bom comsortamento; 17) neste código se ordennar expressamente a atenuação.

Cons. 42 - São... atenuantes; 1) não ter havido... pleno conheimerto do mal e direta intenção de o praticar; 2) desafrontar-se le grave injuria, ou seu conjuge, ascendente e descendente; 3) em defesa la propria pessoa ou de seus direitos ou das pessoas e direitos de sua amilia ou de $3 .^{\circ}$; 4) opondo-se á eexcução e ordens ilegais; 5 ) provocação magressão da parte do ofendido; 6) para evitar mal pior; 7) por ımeaças ou constrangimento físico vencivel; 8) em obediencia á ordem le superior hierárquico; 9) exemplar comportamento anterior ou bons :erviços á sociedade; 10) embriaguez incompleta e não procurada .. 1ão sendo acostumado a cometer crimes nesse estado; 11) maior de 18 e menor de 21 .

Art. 47 - Se concorrerem com circunstancias que agravem - crime outras que o atenuem, o juiz atenderá apenas ás que lhe areçam preponderantes, devendo considerar como taes ao que enendam com a natureza dos motivos e a intensidade do doio ou 0 rau da culpa. Se lhe parecer que existe equivalencia entre umas outras, ajuizará o juiz da gravidade do crime, como se nenhuma lelas se tivesse verificado.

Pr. - No concurso de agravantes e atenuantes, a pena se aproxiıará do limite indicado pelas circunstâncias preponderantes, e como taes e qualificarão as que resultarem dos moveis do crime, da personalidade o criminoso e da reincidencia.

Cons. 38 - No concurso de circunstâncias atenuantes e agravantes rrevalecem umas sôbre as outras ou se compensavam, observadas as seuintes regras: $\S 10^{\circ}$ Prevalecerão as agravantes: a) quando preponerar a perversidade do criminoso, a extensão do dano e a intensidade to alarme causado pelo crime; b) quando o criminoso fôr avesado raticar más ações ou desregrado de costumes: $\S 2 .^{\circ}$ Prevalecerão as 
atenuantes: a) quando o crime não fôr revestido de circunstancia indicativa de máior perversidade; b) quando o criminoso não estiver em condicões de compreender toda a gravidade do perigo da situação a que se expõe, nem a extensão e consequencias de sua responsabilidade. $\S 30^{\circ}$ Compensam-se umas circunstancias com as outras, sendo da mesma importancia ou intensidade ou de igual número. $62, \S 10^{\circ}$ : No concurso de circunstancias agravantes e atenuantes que se compensem, ou na ausensıa de umas e outras, a pena será aplicada no grau médio. $\S 2 .^{\circ} \mathrm{Na}$ preponderancia das agravantes a pena será aplicada entre os graus médio e máximo, e na das atenuantes entre o médio e o mínimo. $\S 3 .^{\circ}$ Sendo o crime acompanhado de uma ou mais circunstancias agravantes sem alguma atenuante, a pena será aplicada no máximo, e no mínimo se fôr acompanhada de uma ou mais circunstancias atenuantes e nenhuma agravante.

Art. 48 - Determinada, dentro dos limites máximo e m nimo fixados na Parte Especial deste Código, a pena que melhor corresponda á gravidade do crime e á personalidade do agente, o juiz só poderá aumentá-la, ou diminui-la, ou substitui-la, nos casos expressos em lei.

$\S 10^{\circ}$ - A diminuição e o aumento versarão sobre a pena que o juiz aplicaria, se a lei não mandasse diminui-la ou aumentá-la.

$\S 20^{\circ}$ - Se a lei não estabelecer a proporção em que a pena deve ser aumentada, o aumento será de um a dois terços.

$\S 30^{\circ}$ - Se a lei não estabelecer a proporção com que deve ser diminuida a pena:

I - a de morte será substituida pela de reclusão por tempo não menor de 24 anos;

II - as de reclusão, detenção e multa serão reduzidas de um a dois terços.

$\S 4 .^{\circ}$ - Concorrendo varias causas da mesma natureza, opera-se o aumentu, ou diminuiçã̃o, sobre a quantidade da pena resultante do aumento, ou diminuição.

$\S 5 .^{\circ}$ - Dado o concurso de causas de aumento e de diminuição da pena, começar-se-á pelas primeiras.

Pr. 102 - Atenuando a pena, poderá o juiz diminui-la ou substitui-la. Diminuindo-a, não lhe poderá ultrapassar o mínimo especifico. Substituindo-a, limitar-se-á 1) a mandar executar como simples a pead 
que deveria ter execução rigorosa; 2) a aplicar a mais branda nas penas alternativas até 2 anos nos crimes comuns ou até nos políticos; 4) a converter em detenção a pena de prisão que não exceder de um ano, observado $o$ art. 61; 5) a impôr a de multa, ao envez de detenção até 6 meses. 103: Nos casos em que expressamente se permitir a livre atenuação da pena, nem ao minimo especifico da mesma estará adstrito o juiz, mas não poderá transpôr o minimo genérico da pena que aplicar. Motivando a decisão, poderá, entretanto, abster-se de qualquer pena nos casos levissimos, punidos sómente com multa ou com detenção por menos de um mês. 105: Agravando a pena, poderá - juiz aumentá-la ou substituil-a. Aumentando-a, só nos casos expressos poderá transpôr-lhe o máximo especifico. Substituindo-a, limitar-se-á: 1) a dar execução rigorosa á pena que poderia ter execução simples; 2) a aplicar a mais grave das penas alternativas.

Cons. Omissa.

Art. 49 - Aplicar-se-á, dentre os dispositivos infringidos pela mesma ação ou omissão, o que cominar pena mais grave.

$\S$ único - Se o dispositivo aplicado não importar em medida de segurança ou em efeito de condenação decorrentes de qualquer dos outros, ou importar em efeito ou medida de menor gravidade, aplicar-se-ão nessa parte o outro ou os outros dispositivos.

Art. 50 - Quando, na execução do mesmo designio criminoso, o agente praticar, numa só ocasião ou em ocasiões diversas, várias infrações da mesma natureza, aplicar-se-á, aumentada de um a dois terȩos, a pena cominada para a mais grave das infrações cometidas.

Art. 51 - Quando o agente houver cometido mais de um crime:

I - aplicar-se-á uma só pena restritiva da liberdade, correspondente á duração global das que deveriam ser aplicadas para cada crime, se forem todas da mesma especie, não podendo, porém, a pena aplicada exceder ao triplo da duração da mais grave dentre as concorrentes;

II - aplicar-se-ão distintamente e por inteiro as penas restritivas da liberdade, se forem de especie diferente, devendo, neste caso ser executada a reclusão antes da detenção;

III - aplicar-se-á uma só pena de multa, correspondente á soma de todas aquelas em que o agente houver incorrido, não 
podendo, porém, o total exceder de 150 contos, nem a pena detentiva, em que fôr convertida a multa, exceder de 4 anos.

$\S 10^{\circ}$ - Embora unificadas, as penas correspondentes serão consideradas como distintas na determinação dos efeitos da sentença condenatoria e na imposição de medidas de seguranȩa.

§ 2. - Da mesma forma se procederá:

I - quando, depois de condenação irrevogavel, se deva julgar o agente por crime cometido anterior ou posteriormente á condenação ;

II - quando se houverem pronunciado duas ou mais sentencas condenatorias, com inobservancia do disposto no presente artigo; cabendo, neste caso; a juiz da execução, ex-ofício ou a requerimento do Ministerio Publico ou do condenado, provocar o pronunciamento do tribunal superior.

Art. 52 - Em nenhuma hipótese a pena aplicada ou executada de acordo com os artigos precedentes excederá:

I - de 40 anos, em se tratando de reclusão;

II - de seis anos, em se tratando de detenção;

III - de 150 contos, em se tratando de multa.

Pr. 110 - Aquele que responder por mais de um crime aplicar-se-á a pena do mais grave obrigatoriamente aumentada. O aumento será proporcionado á gravidade dos outros crimes, ás circunstancias em que em que se perpetrarem e á classificação do criminoso, contanto que não exceda a metade da do crime mais grave. Quando, com o aumento, a pena total ultrapassar o respectivo máximo generico, a esta será reduzida. 111: Quando a pena do crime mais grave fôr a da prisão, a execução da pena total será rigorosa, salvo se as condições do condenado o não permitirem. Na pluralidade de multas aplicar-se-á a maior, aumentada de um terço ou da metade, conforme as circunstancias. 112: As regras dos artigos anteriores tambem se aplicam: 1) ao que é julgado por um novo crime, não tendo ainda cumprido a pena do anterior; 2) ao que com unidade e identidade de ação, viola diversas leis criminaes ou diversas disposições de uma delas. 113: Basta que um dos crimes reclame pena acessoria ou medida de segurança, para que qualquer delas se aplique. 114: Quando coexistirem duas ou mais sentenças aplicando ao mesmo individuo penas identicas, sem observancia no disposto no art. 110, a unificação das penas será obtida mediante 
Cons. 66 § $10^{\circ}$ : Quando o criminoso fôr convencido de mais de um crime, impor-se-lhe-ão as penas estabelecidas para cada um deles. § 2. Quando o criminoso deva ser punido por 2 ou mais crimes da mesma natureza resultantes de uma só resolução contra a mesma ou diversa pessoa, embora cometidos em tempos diferentes, se lhe imporá a pena de um só dos crimes, mas com o aumento da sexta parte. § $3 .^{\circ}$ Quando o criminoso pelo mesmo fato e com uma só intenção, tiver cometido mais de um crime, impor-se-lhe-á no grau máximo a pena mais grave que houver incorrido. $\S 3 .^{\circ}$ Se a soma acumulada das penas restritivas da liberdade a que o criminoso fôr condenado exceder de 30 anos, se haverão todas as penas por cumpridas logo que seja completado esse prazo.

\section{Capitulo III}

\section{Dos efeitos da condenação}

Art. 52 - São efeitos necessarios da condenação, quaesquer que sejam o crime ou a pena:

I - constar do registro criminal e do prontuario do condenado a sentença;

II - responder o conđenado pelo pagamento das custas e despesas processuaes, obrigação que será solidaria se houver mais de um condenado pelo mesmo crime;

III - perder o condenado o produto ou provento do crime;

IV - impedir que, no juizo competente para tornar efetiva a responsabilidade civil, se questione, sobre a existencia do crime ou quem seja o seu autor (cod. civ. art. 1.525);

$\mathrm{V}$ - tornar exequivel no juizo civil a sentença criminal, para o fim de se proceder á liquidação do dano causado.

$\S$ unico. - Regular-se-á pela lei civil a obrigação de reparar o dano. Mediante requerimento do ofendido ou de quem o represente, poderá, entretanto, o juiz determinar, a titulo de reparação do dano não patrimonial, a publicação da sentença condenatoria, que se fará na fórma e com as restrições constantes do art. 60 e $\$ \S$.

Pr. 32 - Todo aquele que cometer crime será obrigado a reparar - dano, material ou moral que tiver causado, salvo quando a criminalidade do ato fôr excluida. § $10^{\circ}-\mathrm{A}$ obrigação do inimputável será 
condicionada com a sua capacidade econômica, preferentemente atendida a situação especial em que a inimputabilidade o tiver colocado. \& $20^{\circ}-$ Pela reparação do dano responderão solidariamente os sócios, quando o infrator tiver agido como representante da sociedade. Na co-autoria a obrigação de reparar o dano é solidária, mas havendo entre os co-autores algurn inimputável, será êle requerido em derradeiro lugar, observado o $\S 10^{\circ}$ do art. precedente. 34: A obrigação de reparar o dano passa aos herdeiros do criminoso até o valor dos bens herdados e o direito à reparação aos do ofendido.

Cons. 69 - A condenação do criminoso, logo que passar em julgado, produzirá os seguintes efeitos: 1) - perda em favor da Nação ou dos Estados, dos instrumentos e resultados do crime, nos casos em que o ofendido não tiver direito à restituição; 2) - a obrigação de indenizar o dano; 3) - a obrigação de satisfazer as despezas judiciais. § único - Esta responsabilidade é solidária, havendo mais de um condenado pelo mesmo crime. 70: A obrigação de indenizar o dano será regulada segundo o direito civil.

Art. 53 - São efeitos necessarios da condenação por certos crimes ou a determinadas penas:

I - a publicação da sentença:

II - a inhabilitação;

III - a obrigação, pəra o condenado a pena detentiva, de ressarcir ao Estado as despesas com a sua manutenção durante a prisão preventiva e a execução da pena; obrigação que não se transmite aos herdeiros, nem se estende ao civilmente responsazel.

\section{SECÇão I}

\section{Do registro da sentença}

Art. 54 - A sentença condenatória será registrada na fórma da lei processual e constará do prontuário do condenado.

$\S 10^{\circ}$ - Poderá, todavia, o juiz, ex-oficio ou a requerimento do réo, determinar na própria sentença que delá não se faça menção na folha corrida do condenado e em certidões extraidas a pedido de particulares. 
§ 2. - Não terá aplicação o disposto no $§ 10^{\circ}$, senão quando se realize o concurso das seguintes circunstancias:

I - tratar-se de criminoso ocasional;

II — não militar contra êle circunstância indicativa de maior periculosidade;

III - ser a condenação a pena privativa da liberdade por tempo não maior de 2 anos, ou a multa não superior a $20: 000 \$ 000$, embóra aplisada cumulativamente.

$\S 3 .^{\circ}$ - No caso do condenado cometer novo crime, haver-se-á como revogada a determinação.

Pr. 118 - A pena imposta e todos os incidentes de sua execução constarão do prontuário do condenado. - Omisso, quanto ao restante.

Cons. Omissa.

\section{Secção II}

\section{Da confiscacão}

Art. 55 - 0 condenado perderá em favor da União:

I - os bens que constituirem produto ou provento do crime, ressalvados, porém, os direitos de terceiro, que para o crime não houver concorrido;

II - as armas e outros objetos que tiverem servido ou forem destinados á pratica do crime; salvo se pertencerem a terceiro, que tenha autorização legal para o seu fabrico, alienação, detenção, uso ou porte.

$\S 10^{\circ}$ - Dar-se-á a confiscação das cousas enumeradas no inciso n. II, ainda que não haja condenação, quando o seu fabrico, alienação, detenção, uso ou porte constituam crime.

§ $2 .^{\circ}$ - Não impedem a aplicação deste dispositivo a morte do condenado, a anistia ou o perdão.

Pr. 95 - Será confiscada pela sentença e atribuida ao Estado ou á União a remuneração em dadiva recebida pelo condenado para cometer 
o crime, ressalvados os direitos de terceiro que para ele não tiver concorrido. Executa-se o confisco contra a sucessão, e, feita a partilha contra os herdeiros na proporção de seus quinhoes. § ún. Em favor da vítima, seu conjuge ou filhos, sempre poderá abrir mão o juiz, no todo ou em parte, do direito do Estado ou da União, sobre a cousa confiscada, que se não deva inutilizar ou destruir.

Cons. 69 - perda, em favor da União ou do Estado, dos resultados do crime, nos casos em que o ofendido não tiver direito á restituição.

\section{SECÇão III}

\section{Da publicação da sentença}

Art. 56 - A sentença será publicada uma vez, á custa do condenado, em jornal de grande circulação designado pelo juiz, e, a criterio dêste, parcial ou intgralmente:

I - quando executada a pena de morte;

II - quando, nos crimes de calúnia, difamação ou injúria impressas, o requerer o ofendido ou quem o represente:

III - quando se tratar de usura, usurpação de titulo ou função, exercicio ilegal de profissão ou oficio, adulteração de substancias alimenticias ou medicinaes, e outras em que o interesse público exija a divulgação.

§ 1.0 - Não se publicará a sentença proferida contra menor de 21 anos; e o nome dêste não constará da publicação, se houver outro condenado de maior idade.

§ 2. - A morte do condenado não obsta a publicação da sentença.

Pr. 92 - A publicação da sentença, à custa do condenado, será dedecretada de ofício quando o exigir interesse publico, $\S 10^{\circ}-$ Quando do interesse das partes, a publicação... poderá ser ordenada: 1) à custa - Estado, do denunciante ou querelante, conforme se trate de ação pública ou particular, se a sentença fôr absolutória e o réo ou o querelado - requerer; 2) - à custa do réo, se o requerer a parte lesada ou alguem que demonstre justo interesse. $\S 2 .^{\circ}-0$ direito de pedir a publicação à custa do Estado ou do particular passa ao conjuge sobrevi- 
vente $\theta$ aos herdeiros até ao $1 .^{\circ}$ gráu, que só poderá exercer dentro de 10 dias depois de transitar a sentença em julgado. 93: A morte do condenado não obsta a publicação da sentença à custa da sucessão. 84: O juiz indicará 1 ou 2 jornais de ampla circulação, em que se pu. blique uma vez só a sentença. A circulação será estimada, tendo-se em vista o meio em que a publicação deve ser feita. § ún. - Sómente existindo razões especiais, a motivação da sentença será publicada; mas nêste caso poderá o juiz destacar dentre os motivos os que bastarem à reparação do lesado.

Cons. Omissa.

\section{SECÇÃo IV}

\section{Da inhabilitação}

Art. 57 - 0 condenado por crime doloso ou preterintencional a reclusão por tempo não menor de 5 anos e o criminoso declarado habitual ou por tendência, incorrem:

I - na perda do cargo, mandato, comissão ou outra função pública, civil ou militar, temporária ou vitalícia, remunerada ou gratuita, de que ache investido;

II - na privação das vantagens da aposentadoria, pensão ou montepio, concedidas por entidade de direito público, salvo se não dispuzer de outros meios para a mantença da família;

III - na incapacidade, durante o dobro da duração da pena infligida, para votar ou ser votado em eleições politicas e para ser investido em qualquer função pública, nos termos do inciso n..$^{\circ} \mathrm{I}$;

IV - na incapacidade permanente para obter ou usar gxxáus e dignidades acadêmias ou distinções honoríficas;

$\mathrm{V}$ - na incapacidade permanente para exercer tutela ou curatela;

VI - na suspensão, durante o tempo da condenação, de todos os direitos decorrentes da autoridade marital e do pátrio poder; salvo se 0 juiz dispuzer de outra forma.

Art. 58 - 0 condenado por crime doloso cometido, no exercício da função pública, em prejuizo da fazenda de entidade de direito público, incorrerá, pelo fato da condenação, na perda, na 
suspensão e nas incapacidades enumeradas no art. precedente, com exceęão da constante do item VI.

Art. $59-0$ condenado por crime doloso ou preterintencional a reclusão por tempo não menor de 3 anos, nem maior de 5, incorre:

I - na perda da função pública, de que estiver investido, nos termos do art. $57 \mathrm{n} .^{\circ} \mathrm{I}$;

II - na suspensão, durante o tempo da condenação, das vantagens da aposentadoria, pensão ou montepio, nos termos e com a restrição constante do art. $57 \mathrm{n}$. II;

III - na incapacidade permanente para o exercício da tutela ou curatela e para a obtenção ou uso de gráus ou dignidades acadêmicas e distinções honoríficas.

IV -na incapacidade, durante o dcbro da duração da pena infligida,

a) para votar e ser votado em eleições políticas;

b) para a investidura em função pública não eletiva.

Art. 60 - Perde o pátrio poder o condenado:

I - por crime de abandono de família ou contra o estado de família em prejuizo do filho;

II - por crime contra o pudor individual, quando a qualidade de pai, ou mãe, fôr elemento constitutivọ do crime ou causa de agravação da pena.

Art. 61 - Perde a autoridade marital o condenado:

I - por crime de bigamia, ou de adulterio, ou de abandono de família em prejuizo da mulher;

II - por crime contra o pudor individual e a moralidade pública, uma vez que elemento constitutivo do crime ou causa de agravação da pena fôr a qualidade de marido

Art. 62 - A condenação por crime cometido com abuso do pátrio poder ou da autoridade marital determina a suspensão desses direitos por tempo correspondente ao dobro da duração da pena infligida, e a partir do dia em que terminar a execução desta última.

Art. $63-0$ condenado por crime cometido com abuso dos poderes ou infrảąão dos deveres inherentes a uma função pública ou ao cargo de tutor ou curador: 
I - perde a função, ou cargo;

II - incorre em incapacidade para a investidura em função pública da mesma ou de outra natureza, ou em tutelà ou curatela, conforme $o$ caso.

$\S$ único - Essa incapacidade será por tempo correspondente ao da pena infligida e a contar do termo de sua execução. Não poderá, todavia, ser menor de um ano, nem maior de cinco, salvo expressa disposição em contrário.

Art. 64 - 0 condenado por crime cometido com abuso dos poderes ou infração dos deveres inherentes a uma profissão ou atividade, cujo exercício dependa de licença, habilitação ou autorização do poder público, incorre na incapacidade para êsse exercício, por și ou interposta pessôa, e por conta própria ou alheia.

$\S$ único - Tal incapacidade será permanente, nos casos expressos em lei; ou temporária, aplicando-se-lhe então o disposto no § úniç do art. precedente.

Art. 65 - Durante o procedimento criminal poderá o juiz decretar a suspensão provisória do exercício de funções públicas ou de algumas dentre elas, do pátrio poder, da autoridade marital, da tutela ou curatela e da profissão ou atividade, uma vez que, atentas a espécie e a gravidade do crime, a condenação eventual importe na inhabilitação para tal exercício.

§ único - 0 tempo da suspensão provisória computar-se-á no da inhabilitação temporária, consequente à condenaȩão.

Pr. 85 - A pena de interdição é absoluta ou relativa e consiste em perda ou suspensão: 1) - do direito eleitoral, ativo ou passivo; 2) - do exercicio das funções públicas de eleição ou nomeação; 3) da prerrogativa cívica de concorrer para a composição do tribunal do juri e das forças armadas da Nação; 4) - da capacidade de ser testemunha instrumentária em juizo ou em atos públicos e testamentos; 5) - da capacidade para a chefia da sociedade conjugal ou para 0 exercício do pátrio poder, da tutela ou curatela; 6) - da capacidade para o exercício de arte, ofício de arte, ofício, indústria ou profissão; 7) - do direito de usar distinções honoríficas nacionais. 86: A partir de 4 anos, a condenação à pena de prisão privará o condenado do cargo, emprego ou função pública que exercia e das vantagens que lhe forem 
inherentes, salvo as do montepio. 87: A interdição de que trata o n. ${ }^{0}$ II, parte final, do art. 95 será absoluta, embóra a pena seja inferior a 4 anos, quando, cometendo o crime, houver o funcionário público lesado ou tentado lesar a fazenda pública ou particular. 88: A interdição de que trata $\circ \mathrm{n} .^{\circ} \mathrm{V}$ do art. 85 será absoluta, quando resultar manifesta a incompatibilidade do autor do crime com o exercício dos direitos ou funções, de que o privar a sentença. 89: Toda a pena privativa da liberdade por menos de 4 anos poderá ser acompanhada de interdição relativa; quando, porém, dos móveis do crime e das circunstâncias resultar evidente a incompatibilidade do culpado com o exercício atual ou com o gozo atual da pensão, emprego, ou cargo, prerrogativa, regalia ou distinção de que o privar a sentença, a interdição relativa acompanhará a pena principal. 90: A interdição quando relativa, será sempre por prazo certo, não menor de 1 ano, nem maior de 3 . $\S$ ún. - A interdição de direitos políticos é sempre relativa e será facultativa quando a pena imposta fôra de detenção por menos de 6 mêses. 91: A interdição de que trata o n. ${ }^{\circ}$ IV do art. 85 acompanhará a pena principal toda vez que a inaptidão técnica, intelectual ou moral tiver concorrido para 0 crime ou constituir perigo para o próprio criminoso ou para a sociedade.

Cons. 55 - O condenado à pena de prisão cellular, maior de 6 anos, incorre por tal fato em interdição, cujos efeitos são: 1) - suspensão de todos os direitos políticos; 2) - perda de todo o ofício eletivo, temporario ou vitalício, emprego público da Nação ou dos Estados, e das respectivas vantagens e vencimentos; 3 ) - perda de todas as dignidades, condecoraçc̃es e distinções honoríficas; 4) - perda de todos os munus públicos. $\$$ único - Sempre que a lei aplicar, além da pena corporal, a de privação do exercício de alguma arte ou profissão, esta pena só produzirá os seus efeitos depois de cumprida a corporal. 56: A pena de perda de emprego importa necessariamente a de todos os serviços e vantagens. 57: A pena de suspensão do emprego privará o condenado de todos os seus empregos durante o tempo da suspensão, no qual não poderá ser nomeado para outro.

\section{SECÇão V}

\section{Da rehabilitação}

Art. 66 - A rehabilitação consiste :

I - no cancelamento do registro da sentença;

II - na extinção das incapacidades resultantes da condenação. 
Art. 67 - Conceder-se-á a rehabilitação:

I - decorridos 5 anos a partir do dia em que a pena haja sido cumprida ou se tenha extirito, prazo que passará a ser de 10 anos, contados da mesma forma, em se tratando de criminoso reincidente, e contados da revogação da órdem de recolhimento a estabelecimento de trabalho obrigatorio, em se tratando de eriminoso habitual ou por tendência;

II - uma vez que o condenado tenha:

a) reparado o dano ou demonstrado a impossibilidade de fazê-lo;

b) e justificado por seu comportamento a presunção de emenda.

$\S 10^{\circ}$ - A prova da reparação do dano ou da impossibilidade de repará-lo será dispensada, se o caso fôr de suspensão ou perda do pátrio poder; e substituida pela certidão da sentença que julgar bôas as contas prestadas, na hipótese de inhabilitação para a tutela ou curatela.

$\S 20^{\circ}-\mathrm{Da}$ sentença que conceder a rehabilitação laverá recurso ex-ofício, com efeito suspensivo.

$\S 3 .^{\circ}$ - Na sentença que denegar a rehabilitação, por não estar provado algum dos requisitos legais, marcará o juiz o prazo para a renovação do pedido.

Art. 68 - Não têm direito à rehabilitação :

I - o condenado submetido a medida de segurança, que não a de expulsão a de confiscação, enquanto não tiver sido ela revogada;

II - no que respeita ao pátrio poder, tutela ou curatela, o condenado por crime contra o pudor individual ou a moralidade pública, em detrimento de filha, tutelada ou curatelada;

III - no que se refere à autoridade conjugal, o condenado por crime de lenocinio.

Art. 69 - Revogar-se-á a rehabilitação, no caso de nova condenação por crime doloso ou preterintencional a pena privativa da liberdade.

Pr. 145: - Decorrido tempo igual ao da pena cumprida e nunca inferior a 3 anos, o condenado à interdição dos direitos cívicos poderá rehabilitar-se a exercê-los, provando haver mantido durante aquele prazo comportamento regular e reparado o dano causado ou se esforçando por 
fazê-lo na medida de suas posses. $\S 10^{\circ}-$ As mesmas regras e prazos serão observados: I - quando se tratar do exercício de funções públicas; II - quando se tratar do exercício de indústrias, arte, ofício ou profissão, do pátrio poder, da tutela e da curatıla, dispensada no antepenúltimo caso, a prova da reparação do dano, e substituida esta, nos dois últimos, pela sentença julgando as contas bem prestadas. $\S 20^{\circ}-0$ que decaiu do pátrio poder, tutela ou curatela, por haver carnalmente abusado da filha, tutelada ou curatelada, não se poderá rehabilitar ao exercício dessas funções nem ás da chefia da sociedade conjugal o marido condenado por proxeneta. 146: Poder-se-á conceder a rehabilitação àquele que houver cumprido pena menor de 5 anos, quando provar: 1) - ter mantido bom comportamento durante 10 anos... depois do cumprimento... 2) - haver reparado o dano ou se esforçado... podendo o juiz fixar uma soma provisória, quando ainda não estiver liquidada a indenização $\S 10^{\circ}-0$ praze do . $^{\circ} 1$ será de 4 anos, quando... detenção por menos de 1 ano. $\S 2:^{\circ}-$ Motivando a decisão, poderá o juiz denegar a rehabilitação, quando se convença que o rehabilitando simúla o arrependimento. 147: A rehabilitação... revogada, não se podendo mais repetir, se ao rehabilitado fôr imposta nova pena privativa... 148: Nenhum efeito... a sentença... antes de confirmada pela 2..$^{a}$ instância em recurso necessário, e, quando.. denegada, novo prazo se poderá marcar... 149: O registro. cancela-se corn a rehabilitação, mas com a revogação se restaura.

Cons. Omissa.

\section{Capitulo IV}

\section{Da condenação de execução condicional e da liberdade condicional}

\section{Seç̧Ão I}

\section{Da condenação de execução condicional}

Art. 70 - Na sentença condenatória poderá o juiz suspender a execução da pena, por tempo não menor de 3 anos, nem maior de 6, verificado o concurso dos requisitos seguintes:

I - não exceder de um ano a pena privativa da liberdade que fôr infligida, ou que resultar da conversão da multa, ou que uma e outra, somadas, perfizerem; 
II — não ter o réo sofrido, no Brasil ou no estrangeìro, outra condenação por crime doloso ou preterintencional;

III - autorizarem os motivos determinantes e as circunstâncias do "crime e os antecedentes e o caráter do condenado a previsão de que este não tornará a delinquir.

$\S 10^{\circ}$ - Elevar-se-á a 2 anos o limite da pena estabelecida no inciso n..$^{\circ}$, se o condenado fôr maior de 18 anos e menor de 21 ou maior de 70 .

$\S 2 .^{\circ}-$ Quando tenha sido imposta pena de multa cumulativamente com pena privativa da liberdade, poderá o juiz suspender a execução de ambas, nos termos do $n .^{\circ} 2$, ou de uma só.

$\S 3 .^{\circ}$ - A suspensão não atinge os efeitos da condenação, nem as obrigações civis resultantes do crime.

$\S 40^{\circ}$ - A sentença, devidamente fundamentada, especificará as condições a que subordinar a suspensão, entre as quais:

I - a de fixação da residência em determinado lugar;

II - a de abstenção de bebidas alcoólicas, jogos de azar e outros vicios igualmente perniciosos, obrigação que implica a de não frequentar estabelecimentos ou lugares onde êles as pratiquem;

III - se o permitirem as condições econômicas do condenado, a de fazer, em prazo prefixado, o pagamento das custas e despesas judiciais, e a de reparar o dano, uma vez efetuada a sua liquidação.

$\S 5 .^{\circ}$ - Revogar-se-á a suspensão da execução da pena nos mesmos casos e da mesma fórma por que se revoga o livramento condicional.

$\S 60^{\circ}$ - Se expirar o prazo mareado, sem que se tenha revogado a suspensão condicional, a condenação haver-se-á como inexistente para o efeito do cumprimento da pena.

§ $7 .^{\circ}$ - Não se concederá a suspensão da execução da pena, quando esta se tenha de converter em segregação.

Pr 119 - A execução da pena poderá ser suspensa, por prazo expressamente fixado entre 2 a 4 anos, concorrendo as seguintes condições: 1) ser o crime comum e o criminoso primário; 2) ter-lhe sido imposta pena privativa da liberdade, que não seja a de prisão por mais de 1 ano, salvo o disposto no art. 120 ; 3) não serem vís os moveis que o determinaram cometer o crime; 4) não ser a suspensão contra-indicada 
pelas circunstancias do crime ou pelos antecedentes pessoais, familiares ou sociais do condenado, ou pela categoria criminal em que deva ser classificado. 120 - Observado o n. 4 do art. precedente, a execução da pena de prisão imposta no mínimo ao criminoso primário por crime contra a vida ou integridade corpórea, cometido sob o dominio de paixão, que as circunstâncias tornem excusavel, poderá ser suspensa por prazo expressamente fixado entre 3 e 6 anos, para o homicidio ou tentativa de homicidio, entre 2 a 4 e para a lesão corporal. $\S 10^{\circ}$ Tratando-se de lesão corporal leve, será indiferente a quantidade da pena e o prazo da suspensão não excederá de 3 anos. $\S 20^{\circ}$ Verificada quanto ao crime, - criminoso e a pena as condições especificadas neste artigo, suspender-se-á a execução da pena toda a vez, que respondendo a quesitos de defesa, declarar o conselho de sentença não militar contra a suspensão nenhuma das restrições do n. 4 .. e que êle a julga conveniente. $\S$ 3. Concorrendo as condições deste art., tambem o juiz singular poderá suspender a execução da pena quando da sua competência fôr o julgamento. 121 - A sentença será sempre motivada e dela constarão as regras pelas quais tetá o condenado de pautar o seu comportamento durante o periodo de prova. 122 - Para o efeito do cumprimento da pena a sentença condenatoria será considerada inexistente e cancelado seu registro provisorio, se, durante o periodo de prova, nova condenação por delito comum, no país e no estrangeiro, não fôr imposta ao condenado, nem persistentemente êle infringir as regras de comportamento a que o tiver submetido a sentença de suspensão. 122 - Se alguma das hipóteses do art. precedente verificar-se ou o condenado solvente não reparar o dano já liquidado por sentença passada em julgado no civil ou não provar ter-se esforçado por fazê-lo na medida de suas posses, revogará o juiz a suspensão e fará cumprir a pena. $124-\mathrm{A}$ suspensão da pena principal não desonera da pena acessoria nem das incapacidades e restrições de direitos que decorram da pena principal ou com estas tenham sido pronunciadas; não o desobriga das reparações, indenizações e restituições devidas, nem das custas e despezas judiciais, para o pagamento destas, se poderá marcar-lhe o prazo razoável. 125 - Não se suspende a execução da pena: 1) nas condenacões consistentes, em multa, salvo quando verificar-se a hipótese do art. 55 (inexecução de multa, por insolvência); 2) nas em que a multa se cumule $\Theta$ o condenado solvente previamente a não pagar; 3) nos crimes de ação privada, reprimidos com prisão por mais de um ano, salvo quando o ofendido maior e capaz der o seu consentimento e este não estiver por indicios graves, inquinado de imoralidade; 4) naqueles em que o ofendido fôr menor, interdito ou em condiçōes de ser interditado, ou fôr invalido, valetudinário ou incapaz de defender-se ou a incapacidade resultar de ação predeterminada do ofensor. 
Cons. 51 - Em caso de primeira condenação às penas de multa conversivel em prisão ou de prisão de qualquer natureza até 1 ano, tratando-se de acusado que não tenha revelado caráter perverso ou corrompido, tendo-se em consideração as suas condições individuais, os motivos que determinaram e circunstâncias que cercaram a infração da lei penal, poderá ser suspensa a execução da pena por um prazo fixado de 2 a 4 anos se se tratar de crime, e 1 a 2 anos, se de contravenção. § $1 .^{\text {ò }}$ Se, no prazo fixado, a contar da data da sentença tiver sido imposta outra pena ao acusado, por fato anterior ou posterior a sentença será revogada e executada imediatamente a pena de fórma a não se confundir com a segunda condenação. $\& 20^{\circ}$ A suspensão não compreende as penas acessorias e incapacidades, nem os feitos relativos à indenização do dano resultante da infração. $\$ 3 .^{\circ}$ A sentença será subordinada à obrigação de fazer o condenado as reparações, indenizações ou restituicõos devidas, salvo o caso de insolvência provada e reconhecida. Será fixado um prazo para o acusado pagar as custas do processo, tendo-se em atenção as suas condições economicas ou profissionais. § $4 .^{\circ}$ Cessarão os efeitos penais da condenação no dia em que ela fôr declarada inexistente. $\S 6 .^{\circ} \mathrm{A}$ s. c. só poderá ser concedida uma vez, salvo se a $1 .^{a}$ houver sido aplicada em processo de contravenção que não revele vicio ou má índole. 52 - Não haverá s. c. nos crimes contra a honra e a bôa fama (salvo se cometido pela imprensa), contra a segurança e a honestidade das familias; nos crimes dos arts. 165 e 178 (eleitorais) e contravenções do art. 368 (loterias).

\section{SECÇÃo II}

\section{Do livramento condicional}

Art. 71 - Poder-se-á conceder livramento condicional ao condenado a pena privativa da liberdade por tempo não menor de 4 anos, que tiver:

I - cumprido mais da metade da pena, quando primário, e mais de $3 / 4$, quando reincidente, habitual ou por tendência;

II - demostrado por seu bom comportamento durante a vida carcerária e por sua aptidão para prover à própria subsistência, que está em situação de ser restituido, sem perigo, ao meio social;

III - satisfeito as obrigações civis resultantes do crime e impostas na sentença, ou provado a impossibilidade, em que se encontra de satisfazê-las. 
§1.- 0 livramento condicional não será concedido, sem prévio parecer do Conselho Penitenciário, que ouvirá o diretor e o médico do estabelecimento, em que estiver internado o liberando, e procederá às outras diligências que entender convenientes. Em se tratando de condenado á segregação, exigir-se-á exame pericial, que conclua pela ausencia de periculosidade.

$\S 20^{\circ}-$ Ao conceder o livramento condicional, o juiz estabelecerá as normas de comportamento, que deverá observar o liberado até ao termo da pena infligida; e entre elas:

I - a obrigação da residência em determinado lugar;

II — a de abstenção de bebidas alcoólicas, jogos de azar e outros vícios igualmente perniciosos, com a proibição de frequentar lugares em que êles se pratiquem;

III - a de adotar, em prazo prefixado, ocupação honesta, se não tiver meios bastantes de subsistência.

Pr. 126 - Aquele que estiver cumprindo pena de prisão por mais de 1 ano, poderá ser solto antés de inteiramente cumprí-la, concorrendo as seguintes condiçōes: I - ter o criminoso primário cumprido metade da pena, e $2 / 3$ o criminoso por índole ou reincidente; II - do conjunto da vida carcerária do condenado poder-se razoavelmente presumirlhe a correção; III - poder-se prever de suas aptidões e propósitos que procurará viver de trabalho honesto. 131 - Não se concederá àquele que, podendo reparar o dano causado com o crime e já definitivamente liquidado no cível, não o repara ou não prova haver se esforçado por fazê-lo na medida de suas posses. 129 - Ao liberado marcará o juiz um período de prova, na decisão em que lhe conceder o 1. c., ao mesmo tempo aduzindo as razões por que o concede e especificando as condições a que o subordina, como seja: 1) submissão a algum patronato; 2) proibição de frequentar estabelecimentos de certa espécie ou de morar em determinado lugar ou bairro; 3) observância de certas normas de comportamento; 4) promessa, que se tomará por termo, de coibir-se o liberado de hábitos viciosos ou nocivos e, de em tomar determinado prazo, ocupação honesta. 126 - A condição do $\mathrm{n}^{\circ}$. II dêste art. verificar-se-a mediante consulta ao registro diário da vida carcerária do condenado, e, onde não houver registro, mediante inquérito com a assistência do Ministério Público. 128 - 0 l. c. não será concedido sem a audiência do Conselho Penitenciário, onde existir oficialmente organizado, ficando o liberad̉o sob a proteção do patronato ou, na falta dêste, de algum homem bom do lugar que se prestè a protegê-lo e guiá-lo. 
Cons. 50 - Poderá ser concedido 1. c. a todos os condenados a penas restritivas da liberdade por tempo não menor de 4 anos, de prisão de qualquer natureza, desde que se verifiquem as condições seguintes: a) cumprimento de mais da metade da pena; b) ter tido o condenado, durante o tempo de prisão, bom procedimento indicativo de sua regeneração; c) ter cumprido, pelo menos, $1 / 4$ da pena em penitenciária agrícola ou em serviços externos de utilidade pública. $\S 10^{\circ}$ Não prejudicará a concessão do l. c. o fato de não ter sido o condenado transferido para penitenciária agrícola ou empregado em serviços externos ... se essa transferência ... não se tiver dado por circunstâncias independentes de sua vontade. Nêsse caso ... 2/3 da pena. O decreto 24.357 , de 34 , autoriza a concessão aos condenados por mais de 1 ano.

Cons. $57 \S 4 .^{\circ}$ - 0 liberado ficará submetido às condições convenientes, tais como submissão a um patronato, observância .. proibição de morar em determinado lugar, abstenção de bebidas alcoólicas, adoção de meio de vida honesto, dentro de prazo fixado.

Art. 72 - Revogar-se-á o livramento condicional se, durante a vigência, o liberado:

I - cometer novo crime;

II - fôr condenado por crime praticado anteriormente;

III - infringir qualquer das obrigações a que estiver sujeito.

$\S 1 .^{\circ}$ - Verificada a hipótese do n. ${ }^{\circ}$ III, poderá o juiz atentas as circunstâncias, revogar desde logo o livramento, ou advertir o liberado, marcando-lhe prazo, quando cabível, para cumprir a obrigação. A falta de cumprimento da obrigação no prazo marcado ou a prática de outra infração acarretam a revogação do livramento.

$\S 2 .^{\circ}$ - Revogado o livramento, o condenado:

I — não poderá obtê-lo novamente;

II - voltará a cumprir a pena pelo tempo que faltava na data da libertação;

III — não terá contado para a prescrição, nem computado na pena o período em que houver gozado do benefício.

Pr. 133 - 0 1. c. será revogado: 1) se o liberado, durante o período de pena, incorrer em crime cuja pena seja a de detenção, prisão ou relegação; 2) se não cumprir as condições que lhe tiverem sido impostas na sentença. $\mathrm{Na}$ 1. $^{\mathrm{a}}$ hipótese a revogação operará de pleno direito, e na segunda mediante decisão do juiz. $134-0$ tempo em que o 
liberado estiver solto não será computado na pena nem se contará para a prescrição, que nêste caso não poderá ser de novo concedido. 135 Nela (pena) se reintegrará o condenado pelo tempo que lhe faltava cumprir na data do livramento, se êste se revogar. Nêste caso poderá o juiz determinar na sentença que a pena se cumpra sob regime severo.

Cons. $50 \S 70^{\circ}-0$ l. c. será revogado: 1) se o liberado vier a ser condenado por qualquer infração penal que o sujeite a pena restritiva da liberdade; 2) se não cumprir as condiçōes .. impostas na sentença. $\S 8 .^{\circ} \mathrm{Em}$ caso de revogação do 1 . c. não será computado na duração da pena o tempo em que o liberado esteve solto, não correrá prescrição, nem se lhe concederá mais aquele benefício.

Art. 73 - Se não se revogar o livramento condicional, até ao termo da pena imposta, haver-se-á esta por extinta. Ficarão, outrossim, de nenhum efeito as medidas de segurança determinadas na sentença condenatória ou em decisão posterior.

Pr. 135 - Vencido o período da prova, ter-se-á por cumprida a pena.

Cons. $50 \S 90^{\circ}$ - Expirado o prazo ... sem revogação, a pena se terá por cumprida.

\section{TITULO $\nabla$}

\section{Das medidas de segurança}

\section{Capítulo I}

\section{Das medidas de segurança em geral}

Art. 74 - Não se imporá medida de segurança sem disposição legal que a estabeleça ou fóra dos casos que a lei determine.

$\S$ único - Aplicar-se-á a lei em vigor ao tempo da sentença. Prevalecerá, todavia, quando diversa, a que vigorar ao tempo em que se deva executar a medida de segurança.

Pr. 150 - As medidas de segurança só se aplicam... de acôrdo com a lei vigente no momento da sentença.

Cons. Omissa. 
Art. 75 - As medidas de segurança impor-se-ão ao estrangeiro:

I - quando o crime seja cometido e julgado no Brasil;

II - quando se julgue no Brasil o crime cometido em outro país;

III - quando se realize a hipótese do art. $6 .^{\circ}$.

$\S 10^{\circ}$ - No caso do inciso $n .^{\circ}$ III a imposição dàs medidas de segurança cabiveis, que são as pessoais, dependerá da verificação judicial da periculosidade do agente.

§ $20^{\circ}$ - A imposição das medidas de segurança não impedirá a expulsão do estrangeiro pelo Governo da União, nos casos previstos em lei.

Pr.: Omisso.

Cons.: "

Art. 76 - Requer-se para a imposição de qualquer medida de segurança o concurso das seguintes condições:

I - ter o indivíduo cometido crime ou ato, que para tal efeito lhe seja equiparado por expressa disposição de lei;

II - haver a certeza de que trata de indivíduo perigoso, tal a probabilidade de que volte a delinquir.

Art. 77 - Equiparam-se ao crime, para a imposição de medidas de segurança:

I - a tentativa de crime impossivel;

II - o ajuste e a instigação, quando o crime não fôr cometido.

Art. 78 - Presumem-se indivíduos perigosos, pelc que deverá sempre o juiz submetê-los à medida de segurança adequada:

I - os que, nos termos do art. 15, não forem passíveis de pena;

II - os que, de acordo com o art. 16, forem condenados a pena diminuída;

III - os condenados por crime cometido em estado de embriaguez pelo alcool ou substância de efeitos análngos, quando habitual a embriaguez;

$I \vec{V}$ - os condenados como criminosos reincidentes, habituais Ou por tendência; 
$\mathrm{V}$ - os condenados por lenocínio;

VI - os condenados como partícipes de associação, bando ou quadrilha de malfeitores;

VII - os condenados por vadiagem (art. 216), mendicância (art. 217), exploração da credulidade publica (art. 218) e exploração de jogos de azar.

$\S 10^{\circ}$ - Não prevalecerá, todavia a presunção constante dêste dispositivo, e a imposição ou a execução não iniciada da medida de segurança ficarão dependentes de verificação judicial, na forma do artigo seguinte:

I - no caso de terem mediado dez anos entre a data do crime e a de sentença de absolvição ou condenação de agente, que não seja passivel de pena (art. 15) ou seja passivel de pena diminuida (art. 16), por fato punível com a morte ou com a reclusão menor de 10 anos;

II - no caso de terem mediado cinco anos, entre as datas supramencionadas, em qualquer outra hipótese;

III - no caso previsto pelo art. $6 .^{\circ}$ n. ${ }^{\circ}$ II.

§ 2. - Não prevalecerá tambem a presunção, quando a inimputabilidade fôr devida a estado transitório de alienação mental, e as condições pessoais do agente, comprovadas mediante perícia médica, e as circunstâncias do fato excluirem a existência de qualquer periculosidade.

Art. 78 - Fóra dos casos em que existir a presunção legal de periculosidade, competirá ao juiz verificar, em face do caso concreto, se o indivíduo é, ou não, perigoso.

$\S$ único - No exercício dêsse poder, o juiz terá em consideração as circunstâncias do crime e a personalidade do agente, de acôrdo com os critérios constantes dos arts. 44, 45 e 46, atendendo particularmente ás relações que existam porventura entre o crime, de uma parte, e, de outra parte, a ociosidade, vagabundagem ou prostituição, o abuso de álcool ou substância de efeitos análogos, e as influências do meio em que tenha o agente vivido.

Pr. 150 - As m. s. só se aplicam depois de cometida a infração, quando socialmente perigoso o infrator. 151: A periculosidade social assenta na legitima previsão de que o autor do crime ou contravençạ̈ 
provavelmente os repetirá. 152: A previsão deverá decorrer 1) - da inimputabilidade ou da imputabilidade restrita daquele a quem se tenha de aplicar a medida; 2) - da categoria criminal em que deva ser classificado; 3) - da relação existente entre a infração e a ociosidade, a mendicância, a vagabundagem e a prostituição; 4) — da relação existente entre a infração e o uso do alcool ou de substâncias entorpecentes ou tóxicas; 5) - da relação existente entre a infração e as influências perniciosas do meio em que tenha vivido ou viva o infrator.

Cons. Omissa.

Art. 80 - A imposição das medidas de segurança far-se-á na própria sentença de condenação ou absolvição.

$\S 10^{\circ}$ - Em qualquer fase do processo anterior à sentença, poderá o juiz determinar em caráter provisório a unternação do selvícola, surdo-mudo, alienado, ébrio, ou toxicômano habitual, no estabelecimento correspondente. A ordem será revogada, uma vez que o juiz se convença de que já não mais subsiste o estado de periculosidade. Convertida pela sentença em internação definitiva infrações da mesma natureza, aplicar-se-lhe-á, aumentada de um a a internação provisória, o juiz, atentas as circunstâncias, mandará ou não, que a duração da segunda se compute na duração mínima. da primeira.

§. 2. - Depois da sentença a medida de segurança poderá. ser imposta :

I - no caso de condenação, durante a execuçã! da pena ou durante o tempo em que a ela se subtrair o condenado;

II - no caso de absolvição, em se tratando de agente que a lei presume perigoso, enquanto não houver decorrido tempo equivalente à duração mínima da medida de segurança aplicável.

III - nos outros casos expressos em lei.

Pr. 153: As m. s. concorrem com a pena ou a substituem. São aplicadas afinal com a sentença, mas tambem o podem ser provisoriamente no curso do processo. O tempo da medida detentiva provisória será computado no da definitiva.

Cons. Omissa. 
Art. 81 - Quando o agente responder por vários crimes ou atos, que importem na imposição de várias medidas de segurança, impor-se-á apenas uma, se forem todas da mesma espécie.

$\S 10^{\circ}$ - Se forem de espécie diferente, o juiz apreciará complexivamente $o$ perigo social, que $o$ agente representa, e; de acôrdo com tal apreciação, imporá uma ou várias dentre as medidas apli. cáveis. Quando, porém, figurar entre estas algumas das medidas detentivas, que a lei estabelece para o caso de periculosidade presumida (art. 78), não deixará de impô-la o juiz.

$\S 20^{\circ}$ - Observar-se-á tambem o disposto nêste artigo, em se tratando de medida de segurança em execução ou cuja execução não se haja iniciado.

$\begin{array}{lc}\text { Pr.: } & \text { Omisso. } \\ \text { Cons.: } & ="\end{array}$

Art. 82 - Não se revogará a medida de seguraıça, eñquanto não cessar o estado perigoso que a houver determinado.

$\S 10^{\circ}-\mathrm{A}^{\prime}$ expiração do prazo mínimo fixado pela lei para a duração da medida de segurança imposta, ou antes de expirado o prazo, quando por dois terços de votos o determinar a Côrte de Apelação, o juiz da execução procederá a exame minucioso das condições atuais do agente.

$\S 20^{\circ}$ - Se tiver desaparecido o estado perigoso, revogar-se-á a medida de segurança.

§ $3 .^{\circ}$ - No caso contrário o juiz marcará novo prazo, em cujo termo voltará a examinar as condições do agente; o que não impedirá que o faça a qualquer tempo, em que lhe conste haver cessado a periculósidade.

Pr.: Omisso.

Cons.: "

Art. 83 - As medidas de segurança executar-se-ão:

I - no caso de absolvição ou condenação a pena pecuniária, logo que se torne irrevogável a sentença; 
II - no caso de condenação a pena privativa da liberdade, logo que esta seja cumprida ou que de outro modo fique extinta, se a extinção não impedir a execução da medida.

$\S 10^{\circ}$ - Convertida a pena pecuniária em detenção, durante a execução da medida de segurança, ficará esta suspensa, retomando o seu curso depois de cumprida a pena privativa da liberdade. Da mesma fórma se procederá sempre que o agente houver de cumprir pena restritiva da liberdade, durante a execução da medida.

$\S 2 .^{\circ}$ - Se forem impostas cumulativamente medida de segurança temporária não detentiva e medida de segurança detentiva, só depois de executada a última será executada a primeira.

Pr.: Omisso.

Cons.:

Art. 84 - Se ao agente sobrevier doença mental, antes ou durante a execução de medida de segurança diversa de internação em manicômio judiciário, observar-se-á o seguinte:

I - Tratando-se de alguem que deva ser ou esteja internado em casa de tratamento e custodia ou estabelecimento de trabalho obrigatorio, far-se-á a internação em manicômio judiciario, sem prazo mínimo de duração; e verificado, no caso de cura, que persiste a periculosidade, pnderá o juiz determinar que o individuo seja internado em casa de trabalho obrigatorio, ou que fique submetido á liberdade vigiada.

II - Tratando-se de quem deva ser ou esteja submetido a medida não detentiva ou caução de bom comportamento, cessará a execução de taes medidas; e, restabelecido o agente, verificará o juiz se êle continúa a ser perigoso, impondo-lhe, no caso afirmativo, a medida de segurança não detentiva, que entenda mais adequada.

Pr.: Omisso.

Cons.: " 
Art. 85 - 0 prazo de duração mínima da medida de segurança detentiva recomeçará a correr do dia em que de novo se the der execuȩão, quando a esta o indivíduo se tiver subtraído voluntariamente; salvo em se tratando de internado em manicômio judiciário ou casa de tratamento e custódia.

Pr.: Omisso.

Cons.: "

Art. 86 - A extinção do crime obsta a imposição e faz cessar a execução das medidas de segurança. A extinção da pena só não impede a imposição das que, por lei, podem ser decretadas a qualquer tempo, e a execução das que já houverem sido impostas a condenados mais de dez anos de reclusão. Nêste último caso, porém, substituir-se-á pela liberdade vigiada a internação em instituto de trabalho obrigatório.

Pr.: Omisso.

Cons.: "

\section{Capítulo II}

\section{Das medidas de segurança em espécie}

Art. 87 - As medidas de segurança podem ser pessoais ou patrimoniais.

$\S 10^{\circ}-$ As medidas de segurança pessoais subdividem-se em detentivas e não detentivas.

§ $20^{\circ}$ - São medidas pessoais detentivas, além da internação em reformatorio judiciário, regulada no titulo $\mathrm{V}$ :

I - a internação em manicômio judiciário ;

II - a internação em casa de tratamento e custódia;

III - a internação em instituto de trabalho obrigatório.

$\S 3 .^{\circ}-$ São medidas pessoais não detentivas:

I - a liberdade vigiada;

II - a proibição de frequentar determinados lugares públicos; 
IV - a expulsão, em se tratando de estrangeiro.

$\S 4^{\circ}$ - São medidas patrimoniais :

I - a caução de bom comportamento:

II - a clausura do estabelecimento.

Pr. 154 - As m. s. atingem o patrimônio ou a pessôa. A caução bom comportamento é a única medida da primeira espécie; as seguns são detentivas ou não detentivas. 155: - As m. detentivas serão ecutadas nos seguintes estabelecimentos: 1) - manicômio judiciário; - casa de tratamento e de custódia; 3 ) - reformatório judiciário; - colônia agrícola ou casa de trabalho. 156: São m. pessoais não tentivas: 1) - a liberdade vigiada; 2) - a proibição de frequentar terminados lugares públicos, ou que se lhes possam comparar pela cilidade de acesso.

Cons. 29: recolhimento dos alienados a manicômio ou entrega à mília. Quanto ao reformatório, a matéria está disciplinada no código : menores.

Art. 88 - Se a lei não esquificar a medida de segurança que ve ser imposta:

I - o condenado a reclusão por mais de 5 anos será internado a instituto de trabalho obrigatório;

II - e impor-se-á, nos outros casos, a liberdade vigiada.

Pr.: Omisso.

Cons.: "

Art. 89 - As medidas detentivas executar-se-ão em estabelementos especiais, efetuando-se a internação das mulheres em estalecimntos distintos dos destinados aos homens.

$\S 1,0^{\circ}$ - Onde não houver estabelecimento especial, a medida tentiva será executada conforme a sua natureza:

I - em secção especial de estabelecimento congênere;

II - em secção de estabelecimento de outro gênero, que se nha adaptado especialmente à sua execução; 
III - em seçã̃o especial do manicômio comum, no qual fiquem assegurado o tratamento e a custódia do internado.

§ 2..$^{\circ}$ - Aplica-se às medidas detentivas o disposto no art. 41, com referência aos estabelecimentos penitenciários.

$\S 3 .^{\circ}$ - Nos estabelecimentos destinados à execução das medidas detentivas adotar-se-á um regime de reeducação ou de tratamento e de trabalho, de acôrdo com as condições pessoais do internado. Da remuneração do trabalho deduzir-se-á um terço, no máximo, para ressarcir ao poder público as despesas de manutenção, constituindo pecúlio impenhoravel do internado o restante.

Pr. $155 \S 10^{\circ}$ - Onde não houver estabelecimento especial a medida detentiva, segundo a sua natureza, poderá ser executada; 1) - em seção especial de estabelecimento congênere; 2) - em seç̧ão de esta. belecimento diferente, que se tenha adaptado especialmente à sua execução; 3) - em secção especial de hospício de alienados, na qual, com o tratamento do detento, se lhe assegure a custódia. $\S 2 .^{\circ}-\AA_{s}$ medidas detentivas, segundo a sna natureza, é aplicavel o disposto no art. 66

Pr.: $\quad$ Omisso.

\section{SEÇ̄̃o I}

Da internação em manicômio judiciário

Art. 90 - Será internado em manicômio judiciário o agente de crime doloso ou preterintencional, que não fôr passível de pena por motivo:

I - de alienação mental.

II - de surdo-mutismo. mínima :

$\S 10^{\circ}$ - A internação em manicômio judiciário terá a duração

I - de 10 anos, se para o crime cometido a lei estabelecer a pena de morte ou a reclusão não inferior, no mínimo, a 24 anos; II - de 5 anos, se o crime fôr punido com reclusão por tempo não inferior, no mínimo, a 10 anos; 
III - de 2 anos, se a pena privativa da liberdade, cominada para o crime, fôr no mínimo de um ano.

§ 2. - Se o crime fôr punido com pena restritiva da liberdade, cujo mínimo não chegar a um ano, ou com pena pecuniária, o juiz limitar-se-á a levar a sentença de absolvição ao conhecimento da autoridade policial.

§ 3. $\quad$ Aplicar-se-á o disposto nêste artigo aos menores de 18 anos, que, sob influência de doença mental ou surdo-mutismo, houverem praticado atos previstos na lei como crimes.

$\S 40^{\circ}$ - Não cessará a internação em manicômio judiciário, senão quando, por decisão judicial, mediante prévia audiência do Ministério Público e perícia psiquiátrica, se demonstrar que o agente pode ser submetido a liberdade vigiada, sem perigo para si mesmo ou para outrem.

Pr. 157 - Na mesma sentença em que isentar de pena alguma pessôa por inimputável impor-lhe-á o juiz o internamento se ela fôr perigosa à sociedade. § único - 0 internamento será: 1) - em manicômio judiciário, tratando-se de crime grave, cuja repetição se deva presumir da tendência mórbida do inimputável; 2) - em casa de tratamento e custódia, nos crimes leves, se do resultado da perícia, fôr lícito esperar que com o tratamento a tendência a delinquir desapareça. 158: 0 internamento do inimputável será por tempo indeterminado. §1.0: Se com o restabelecimento do internado tiver provavelmente cessado a sua periculosidade social, fará o juiz suspender o internamento, por prazo que fixará entre um e quatro anos. $\S 20^{\circ}$ : Se durante o prazo fixado por manifestações inequívocas a periculosidade do beneficiado com suspensão novamente se revelar, restabelecerá o juiz o internamento, que então poderá ser noutro estabelecimento. No caso contrário o internamento cessar ácom a terminação do prazo.

Cons. Omissa. 


\section{SecÇão II}

Da internaçáo em casa de custódia e tratamento

Art. 91 - Poderão ser internados em casa de custódia e tratamento, se não parecer melhor ao juiz submete-los a liberdade vigiada ou se as obrigações desta forem transgredidas:

I - durante tres anos, pelo menos, o condenado, nos termos do art. $16 \mathrm{~ns}$. II e IV, a pena diminuida, em consequencia de crime punido com a morte ou a reclusão por tempo não inferior, no gráo mínimo, a 10 anos;

II - durante dois anos, no mínimo, o condenado, nos termos do art. 16 ns. II e IV, a pena diminuida, em consequencia de crime punido com a reclusão por tempo não inferior, no gráo mínimo, a cinco anos;

III - durante um ano, pelo menos, o condenado. nos termos do art. 16 ns. II e IV, a pena diminuida por crime punido com a reclusão ou a detenção por tempo não inferior, no gráo mínimo, a um e dois anos, respectivamente;

IV - durante seis meses, pelo menos, e ainda que a pena aplicada seja por tempo menor, o condenado a pena restritiva da liberdade, por crime cometido em estado de embriaguez habitual pelo alcool ou substancia de efeitos análogos.

$\S$ único - No caso do $\mathrm{n}$. IV deste artigo a internação precederá ou interromperá a execução da pena restitiva da liberdade, quando, ouvidos o Ministério Público e peritos médicos, verificar o juiz que o exigem as condições de saude mental do condenado. Desaparecida a causa determinante da providencia, mas não antes de decorrido o prazo mínimo estabelecido, o condenado passará a cumprir no estabelecimento comum, a pena infligida. Computarse-á no tempo da pena o da internação.

$\S 2 .^{\circ}-$ Não se imporá outra medida detentiva de segurança, quando caiba a internação em casa de custódia e tratamento.

Pr. $159-\AA_{S}$ pessoas de imputabilidade restrita a medida de segurança é aplicada simultaneamente com a pena e se executará depois desta, salvo a execução do $\S 10^{\circ}$ deste artigo. $\S 10^{\circ}$ Somente quando 
expressamente constar de pericia médica ser o cumprimento anterior da pena nocivo ao tratamento, poderá o juiz determinar que se execute em 1.0 logar a medida de segurança. Esta exceção só compreende os casos em que a restrição da imputabilidade se originar de causa mórbida, que comprometa a integridade mental do inculpado. $\$ 2 .^{\circ}$ Verificando-se a hipótese do $\S 10^{\circ}$, ordenar-se-á o seguinte: 1) cessada a execução da medida de segurança, passará o internado ao cumprimento da pena; 2) se, com a terminação do prazo do internamento, não coincidir o restabelecimento do internado, poderá determinar o juiz que aquele se prorrogue por novo prazo fixado nos limites do anterior; 3) se a pericia médica concluir ser o caso insanavel, passará o internado a ser tratado como inimputavel, aplicando-lhe o juiz o internamenta por tempo indeterminado, se a sua periculosidade social subsistir, ou entregando-o á familia no caso contrario. $\$ 30^{\circ}$ Descontar-se-á da pena ałé $2 / 3$ desta, o tempo do internamento, e quando este ultrapassar aquela fração ou absorva a pena, para o cumprimento deste fixará o juiz prazo razoavel. 160: A medida detentiva aplicavel ás pessoas de imputabilidade restrita não excederá a 2 anos e poderá cessar antes de terminado este prazo, com o restabelecimento do internado.

Cons. Omissa.

\section{SECĢ̃̃o III}

Da internação em instituto de trabalho obrigatorio

Art. 92 - Serão internados em instituto de trabalho obrigatorio :

II - durante tres anos, pelo menos, os condenados como crimiminosos por tendencia;

II - durante tres anos, pelo menos, os codenados como crimnosos habituais;

III - durante dois anos, pelo menos, os condenados como reincidentes ;

IV - durante um ano, pelo menos: a) - os condenados a penas privativas da liberdade, cuja periculosidade se relacione com a ociosidade, a vagabundagem ou a prostituição; b) - os selvícolas incompletamente adaptados, uma vez que, convencido de sua periculusidade, o juiz não julgue melhor submete-los á liberdade vigiada.

§ $10^{\circ}$ - 0 internado em reformatório judiciário, com a declaraşo de habitualidade ou tendencia a delinquir, será transferido, 
ao perfazer 21 anos, para instituto de trabalho obrigatorio, onde completará o tempo da internação imposta.

$\S 2 .^{\circ}$ - Na falta de declaração de habitualidade ou tendencia a delinquir não se poderá fazer a transferencia nos termos e para os efeitos do $\S 10^{\circ}$, senão quando ao juiz parecer inconveniente a imposição de liberdade vigiada a internado em reformatorio judiciario, que aí atingiu a maioridade.

$\S 3 .^{\circ}$ - 0 infrator das obrigações resultantes da liberdade vigiada poderá ser internado, durante seis mezes, pelo menos, em instituto de trabalho obrigatorio, se o juiz não entender submetê-lo á caução de bom comportamento.

$\S 4 .^{\circ}-0$ internado em instituto de trabalho obrigatorio, que, por seu procedimento, demonstrar emenda ou regeneração, poderá obter do juiz uma licença-premio anual, não superior a 30 dias, ou uma licença-premio correspondente aos ultimos 6 meses do prazo mínimo da internação, durante os quais será posto em liberdade vigiada.

Pr. 161 - Aos infratores classificaveis como incorrigiveis ou profissionais, ou cuja periculosidade estiver em relação com a mendicancia, a vagabundagem, a prostituição ou com as influencias perniciosas do meio social ou familiar imporá o juiz, simultaneamente com a pena, o internamento em colônia agrícola, casa de trabalho ou reformatório, que será cumprido depois de executar a pena. 162: 0 internamento será por 1 a 3 anos, e poderá cessar depois de 1 ano, se o juiz se convencer de terem sido obtidos os fins a que a medida visara.

Cons. 46 - A pena de prisão correcional será cumprida em colônias fundadas pela União ou pelos Estados, para a rehabilitação, pelo trabalho e instrução dos mendigos válidos, vagabundos e vadios, capoeiras e desordeiros.

\section{SECÇÃo IV}

\section{Da liberdade vigiada}

Art. 93 - Impor-se á liberdade vigiada :

I - durante tres anos, pelo menos, ao condenado á reclusão por tempo não menor de 10 anos; 
II - durante um ano, pelo menos; a) ao internado ou internando em reformatorio judiciario, que completar 21 anos, e não fồ declarado criminoso habitual ou por tendencia, uma vez que o juiz não entenda interná-lo em instituto de trabalho obrigatorio; b) ao obrigado á caução de bom comportamento, que deixar de prestá-la: c) ao condenado como criminoso reincidente ou habitual por explanação de jogo de azar, sendo-lhe imposta cumulativamente a caução de bom comportamento.

III - durante o tempo que restar para o cumprimento da pena, ao liberado condicional;

IV - durante o prazo da licença-premio, ao internado em instituto de trabalho obrigatorio.

Art. 94 - Poderá o juiz impôr a liberdade vigiada, durante um ano, pelo menos:

I - ao egresso de manicomio judiciario;

II — ao condenado á reclusão por mais de um ano;

III - ao condenado egresso de instituto de trabalho obrigatorio;

IV - ao agente que cometer ato equiparado ao crime, para o efeito de imposição de medidas de segurança, caso o juiz não entenda submete-lo á caução de bom comportamento:

V - ao condenado, nos termos do art. 16 ns. II e IV a pena restritiva da liberdade por crime punido com reclusão ou detenção por tempo inferior a 1 e 2 anos, respectivamente, quando ao juiz não pareça melhor interná-lo em casa de custódia e tratamento;

VI - ao condenado que sair curado de manicômio judiciario ou de casa de tratamento e custódia, onde se tenha feito a sua internação por motivo de doença mental sobrevinda no curso da execução de medida de segurança detentiva;

VI - ao transgressor das obrigações resultantes do exilio local;

VII - ao transgressor da proibição de não frequentar determinados logares públicos, se o juiz não optar pela caução de bom comportamento.

Art. 95 - 0 juiz da execução estabelecerá as normas de comportamento, que serão observadas pelo individuo sujeito á liherdade vigiada, e que se devem inspirar no pensamento de evi- 
tar as ocasiões de novas infrações da lei penal. As normas poderão ser modificadas pelo juiz durante a execução da medida de segurança.

$\S 1 .^{\circ}$ - Incumbirá a vigilancia; na falta de órgão especial, ás autoridades policiais.

$\S 20^{\circ}$ - A vigilancia far-se-á de maneira, a facilitar, pelo trabalho, a readaptação social do individuo.

$\S 3 .^{\circ}$ - Aplicar-se-ão, em relação á vigilancia dos liberados condicionaes e dos menores, as disposições que lhes forem peculiares.

Art. 96 - No caso de transgressão das obrigações resultantes da liberdade vigiada:

I - em se tratando de liberado condicional, proceder-se-á na fórma do art. 72 ;

II - em se tratando de qualquer outra hipotese, poderá o juiz atentas a gravidade ou a reiteração das faltas:

a) impor a caução de bom comportamento;

b) ou determinar, conforme o caso, a internação, por 6 meses, em reformatorio judiciario, ou casa de custodia e tratamento, ou instituto de trabalho obrigatorio.

Pr.: Omisso.

Cons.: "

\section{SeCĢ̃̃o V}

Do exilio local

Art. 97 - Poderá o juiz proibir, durante um ano, pelo menos, a estada ou permanencia em uma ou mais comarcas ou regióes do país ao condenado:

I - por crime contra a personalidade do Estado ou a ordem pública; 
II - por crime que, devido ás condições do meio, torne socialmente perigosa a presença do condenado na comarca ou região.

§ único - No caso de transgressão, não só recomeçará a correr o prazo marcado pelo juiz, como poderá este acrescentar a liberdade vigiada ao exilio local.

Pr. 58 - 0 exilio local consiste na obrigação imposta ao condenado de não residir, por tempo não inferior a 3 mêses, nem superior a 4 anos no municipio em que se tiver perpetrado o crime, ou naquele em que residir a vitima, seus conjuges, pais ou filhos ou o proprio condenado. § $10^{\circ}$ Se a previsão de novos crimes o exigir, a interdição de residencia poderá estender-se aos municípios visinhos, e nos crimes exclusivamente politicos, não só a todo um Estado, mas aos que lhe forem limitrofes. § A pena de prisão ou detenção correspondente ao crime constará da sentença em que as impuzer o exílio, e, infringindo este, ao cumprimento daquela passará o condenado. § $3 .^{\circ}$ Não infringe o exilio aquele que, por prazo curto, e mediante permissão do juiz de execução da sentença, voltou ao logar vdado para assistir a pai, filho, irmão ou cónjuge gravemente nfrmo. 59: 0 exilio local só será aplicável quando, concorrentemente, o criminoso fôr primario e o crime se originar de causas locais. § ún. 0 exilio local se aplica: 1) - aos que cometerem crimes político-sociais; 2) - aos militares nos crimes exclusivamente políticos; 3) - ao criminoso primário, que se revelar criminoso por indole. 60: Não será suscetivel de suspensão a execução da sentença que impuzer o exilio local.

Cons. -- Omissa.

\section{SECÇão VI}

\section{Da proibição de frequeniar determinados logares}

Art. 98 - Impôr-se-á a proibição de frequentar, durante um ano, pelo menos, estabelecimentos onde se vendam ao público bebidas alcoólicas, ao condenado:

I - por embriaguez habitual;

II - por crime cometido sob a ação do álcool.

§ único - No caso de transgressão o juiz acrescentará á proibição a liberdade vigiada ou a caução de bom comportamento. 
Pr. 156 - São medidas penais não detentivas... a proibição de frequentar determinados logares públicos ou que se lhes possam equiparar pela facilidade do acesso.

Cons.: Omissa.

\section{SECĢ̃̃o VII}

\section{Da expulsão do estrangeiro}

Art. 99 - Impôr-se-á a expulsão do territorio nacional ao estrangeiro condenado:

I - qualquer que seja o crime, a reclusão por tempo não menor de 5 anos;

II - qualquer que seja a pena:

a) no caso de criminoso reincidente, habitual ou por tendencia ;

b) nos outros casos expressos em lei.

$\S 10^{\circ}$ - A expulsão não tem duração mínima, nem é revogavel pelo juiz.

$\S 20^{\circ}$ - A transgressão do decreto judicial de expulsão é punida como crime na fórma do art. 193.

Pr. 98 - 0 estrangeiro, em condições de ser administrativamente expulso do territorio nacional, que fôr condenado a pena privativa da liberdade por 4 anos ou mais, sê-lo-á tambem na mesma sentença a expulsão, uma vez cumprida a pena principal. Se, porém, lhe tenha sido concedido livramento condicional e tiver ele mantido bom procedimento durante o periodo da pena, a expulsão seré revogada.

Cons. 107 (crimes contra a atual organisação social): Além das penas... será aplicavel administrativamente a de expulsão quando se tratar de estrangeiro a ela sujeitos. 0 estrangeiro expulso que voltar ao paiz, antes revogada a expulsão, ficará, pela simples verificação do fato, sujeito á pena de 2 anos de prisão, após o cumprimento da qual será novamente expulso.

Lei n. 136, de 1935, 21: Fica sujeito á expulsão imediata o estrangeiro, mesmo proprietario de imoveis, que praticar qualquer dos crimes definidos nesta ou na lei n. 38... 


\section{SECÇÃo VIII}

\section{Da caução de bom comportamento}

Art. 100 - Impôr-se-á a caução de bom comportamento, por um ano pelo menos e no máximo por 5 anos, contados do dia em que fôr prestada:

I - ao agente de ato equiparado ao crime, para o efeito de imposição de medidas de segurança, quando ao juiz não pareça melhor submetê-lo á liberdade vigiada;

II - ao transgressor das obrigações resultantes da liberdade vigiada, se o juiz não entender interná-lo, conforme o caso, em instituto de trabalho obrigatorio, casa de custodia e tratamento ou reformatorio judiciário;

III - ao transgressor da proibição de frequentar determinados logares, uma vez que o juiz não prefira sujeitá-lo á liberdade vigiada;

IV - simultaneamente com a liberdade vigiada, ao condenado como criminoso reincidente ou habitual pelo crime de exploração de jogos de azar.

$\S 10^{\circ}$ - O juiz fixará a importancia da caução entre os limites de um conto de réis no mínimo, e cinco contos de réis, no máximo, atentas as condições econômicas do agente.

$\S 2 .^{\circ}-$ A caução far-se-á:

I - mediante o depósito, em caixa econômica ou estação arrecadadora de rendas federais, de dinheiro ou titulos da divida pública da União;

II - mediante garantia constante da fiânça idonea ou hipoteca de bens suficientes.

$\S 30^{0}$ - Se não fôr prestada a caução em prazo razoavel fixado pelo juiz, impôr-se-á a liberdade vigiada.

$\S 40^{\circ}$ - Expirado o prazo da caução, sem que o agente cometa novo crime, cessará de pleno direito a execução da medida, restituindo-se a quantia depositada e havendo-se por extinta a garantia. No caso contrario o depósito reverterá em favor do Tesouro Federal, e tornar-se-á desde logo exigivel a obrigação fidejussoria. 
Pr. 163 - Aos que responderem por ameaças contra pessoa determinada, ou por constantes, perturbações da ordem pública, ou se envolverem repetidas vezes em rixas e desordens em lugares públicos, simultaneamente com a pena ou se abstraindo da pena, imporá o juiz a caução de bom comportamento. 164: Fará o juiz constar do termo da caução as normas de bom comportamento a que se sujeitar o infrator e o prazo, entre 1 a 3 anos, durante a qual a sua observancia será obrigatória. A caução será em dinheiro, de 500\$ até 5:000\$000, segundo a condição social e econômica do infrator, depositado na Caixa Econômica, ou, onde esta tiver agencia, em repartição pública ou estabelecimento da confiança do Estado. Tambem poderá ser fideiussoria, por pessoa cuja solvência ficar privada em juizo. § $3 .^{\circ}$ Se, durante o prazo marcado, não cometer o condenado nenhuma infração, nem deixar de cumprir as obrigações a que se sujeitou, a caução estará extinta e o deposito será restituido. No caso contrario falo-á reverter o juiz aos cofres públicos, declarando quebrada a caução, e, sendo fidejussoria, providenciará para que se the promova a execução.

Cons.: Omissa.

\section{SECção IX}

\section{Da clausura do estabelecimento}

Art. 101 - Impôr-se-á, na sentença de condenação, a clausura, por tempo não inferior a 5 dias, nem superior a 6 meses, da séde e filiais do estabelecimento ou associação:

I - quando aí se pratiquem habitualmente ou habitualmente se favoreçam a venda ou uso de estupefacientes, a receptação de objetos furtados ou roubados, a impressão ou distribuição de publicações contrarias aos bons costumes ou á ordem política e social;

II - e, em suma, quando o estabelecimento ou associação sirva de meio ou de pretexto para a pratica de qualquer outro crime, com abuso da licença obtida ou inobservancia dos regulamentos administrativos.

Pr.: Omisso.

Cons.: " 


\section{$-293-$ \\ TITULO VI \\ Do regime da minoridade}

\section{Capítulo I}

\section{Dos menores de 18 anos}

Art. 102 - Sempre que fôr cometida ação, ou omissão definida como crime, por menor de 18 anos, proceder-se-á ao estudo da personalidade do agente, da situação moral e material da família e das outras condições em que o menor tenha vivido, fazendo-se para êsse efeito as perícias e investigações necessárias.

Pr. - Omisso.

Cod. de Men.: arts. 68 pr. e 69 pr.

Art. 103 - Se, ao tempo do fato o agente não tiver completado 14 anos, observar-se-á o seguinte:

$\S 10^{\circ}$ - Não se formará processo criminal, limitando-se a autoridade à colheita das informações a que se refere o art. precedente;

$\S 2 .^{\circ}-$ Verificado que os motivos, a natureza $e$ as circunstâncias do fato e as condições pessoais do agente não revelam periculosidades poderá ser êle confiado à guarda dos pais ou de terceiro, depois de severamente repreendido, e mediante as condições que a autoridade entender convenientes. A medida será revogável a qualquer tempo, se o reclamar o interesse do menor.

Pr. - Omisso.

Cod. de Men. art. $68, \S 3 .^{\circ} \ldots$

$\S 3 .^{\circ}$ - Verificado que revela periculosidade, ou que está moral ou materialmente abandonado, ou em risco de sê-lo, ou que outro motivo relevante desaconselha a entrega aos pais ou a terceiro, o menor será internado em instituto adequado de educação, 
público ou particular, até completar 21 anos. Mediante prévia informação da direção do instituto, a autoridade competente fará cessar antes dessa época a internação, uma vez desaparecidos os motivos que a determinaram; sendo então o menor confiado à guarda dos pais ou de terceira pessôa.

Pr. - Omisso.

Cod. de Men. art. $68, \S 3 .^{\circ}$ manda recolher a reformatório por 3 a 7 anos...

$\S 4 .^{\circ}-$ Nos casos constantes dos $\S \S$ precedentes a autoridade competente fiscalizará a educação do menor, e poderá submetê-lo à liberdade vigiada na fórma e pelo tempo que entender necessários.

Pr. - Omisso.

Cod. de Men. art. 92 e...

$\S 5 .^{\circ}$ - Depois de haver completado 14 anos, poderá ser internado até completar 21, em reformatório ou secção de instituto de trabalho obrigatorio o menor:

I - que na vigência da liberdade vigiada infrinja de modo grave ou reiteradamente as normas de procedimento impostas pela autoridade;

II - que continue a revelar periculosidade por suas tendêncras anti-sociais ou perversão moral.

Pr. - Omisso.

Art. 104 - Se, ao tempo do fato definido como crime o agente tiver mais de 14 e menos de 18 anos, proceder-se-á da maneira seguinte :

$\S 10^{\circ}$ - No processo especial, que será secreto, a autoridade colherá as informações a que alude o art. 103.

$\S 2 .^{\circ}$ - Em se tratando de fato punido com detenção, internar-se-á o agente em reformatório de menores ou secção espe- 
cial de instituto de trabalho obrigatorio por dois anos no mínimo e no máximo até completar 21 anos.

Pr. - Omisso.

Cod. de Men. arts. 71...

a) Decorridos dois anos, se parecer realizado o objetivo da internação, e mediante prévia informação da direção do estabelecimento, o menor poderá ser transferido para instituto de educação público ou particular.

Pr. - Omisso.

b) Atentos os motivos e as circunstâncias do fatu, a perso. nalidade do menor e as condições do meio em que vive, poderá o juiz suspender condicionalmente a internação do agente e pô-lo em liberdade vigiada, pelo tempo e maneira que entender necessários.

Pr. - Omisso.

Cod. de Men. art. 81...

c) Ficarão sem efeito a suspensão e a liberdade vigiada, se o agente cometer nova ação, ou omissão, definida como crime vu infringir as normas de procedimento que lhe forem impostas, ou de outra forma desmerecer da confiança do juiz ou da autoridade a que estiver confiado.

$$
\text { Pr: - Omisso. }
$$

$\S 3 .^{\circ}$ - Em se tratando de fato punível com reclusão, o agente será internado em reformatório ou seçãa especial de instituto de trabalho obrigatorio, por tempo não inferior a 6 anos, nem superior a 12. Depois de 4 anos de internação, poder-se-á conceder a liberdade condicional, com as cautelas e na forma dos incisos $a$ e $c$ do $\S$ anterior.

Pr. - Omisso.

Cod. de Men. - Diferente (art. 71)... 
Art. 105 - Não se aplicará o disposto nos $\S \S 20^{\circ}$ e $30^{\circ}$ do artigo anterior se 0 -agente revelar periculosidade, em consequência de sua profunda perversão moral ou de suas condições de saúde.

$\S 10^{0}$ - No primeiro caso será o agente recolhido a secção especial de instituto de trabalho obrigatorio, por tempo não menor de 6, nem maior de 12 anos.

a) Decorridos 4 anos sôbre a internação poderá ser transferido para reformatório judiciário, se das informações 'prestadas pela direção do instituto em que estiver internado se concluir que está reformado moralmente; e poderá ser liberado condicionalmente, se, passados 2 anos sôbre a transferência, continuar a dar mostrar de regeneração.

b) Revogar-se-ão a ordem de transferência e a liberação condicional quando, no decurso deles, o agente se demonstrar indigno do beneficio concedido.

\section{Pr. - Omisso.}

$\S 20^{\circ}$ - No segundo caso o agente poderá ser confiado à guarda dos pais ou de terceiro, uma vez que se obriguem e estejam em situação de submetê-lo ao tratamento necessário.

a) Se tal não fôr possível ou não parecer conveniente, será internado o agente em hospital ou estabelecimento adequado ao tratamento.

b) Na hipótese de cura, poderá o juiz submeter o menor a liberdade vigiada.

c) Se ao completar o agente 18 anos não houver desaparecido a periculosidade resultante de seu estado mental, proceder-seá de acôrdo com o disposto nos arts. 90 e seguintes.

Pr. Omisso.

Art. 106 - A internação tem por objetivo submeter o menor a um regime pedagógico adequado á sua reeducação moral, a par da instrução elementar, da cultura física e da aprendizagem de um oficio ou profissão.

$\S$ único - Enquanto e onde não houver todos os estabelecimentos previstos nos artigos anteriores, far-se-á a internação em tantas secções especiais dos estabelecimentos oficiais, quantas sejam 
precisas para que os menores fiquem separados, de acôrdo com o sexo, a idade e o caráter.

Pr. - Omisso.

Cod. de Men. art. 87.

Art. 107 - Não se aplicam aos menores de 18 anos as disposições relativas à reincidencia; mas constitue indicio de periculosidade o fato do menor cometer novo fato definido como crime, da mesma ou de outra especie.

Pr. - Omisso.

Cod. de Men. 85.

Art. 108 - Poderá o juiz abster-se da aplicação das medidas consignadas nos arts. 103 e 104, se já houver decorrido metade do prazo para a prescrição da ação penal e não fôr do interesse do menor executá-las.

Pr. - Omisso.

Cod. de Men. 83.

Art. 1109 - Não se executará a internação que não o tiver sido até 4 anos depois de decretada.

Pr. - Omisso.

Cod. de Men. 84.

Art. 110 - Se, ao tempo do pronunciamento judicial, com referência ao fato cometido dentro de um dos periodos de idade fixados nos arts. 103 e 104, o agente estiver na iminência de entrar ou já tiver entrado no imediato, ficará ao prudente arbitrio do juiz aplicar, dentre as medidas consignadas naqueles dispositivos, a que melhor convenha à emenda do menor.

Pr. - Omisso.

Cod. de Men. - Omisso.

\section{Capítulo II}

\section{Dos maiores de 18 e menores de 21 anos}

Art. 111 - Se, ao tempo do crime, o agente fôr maior de 18 e menor de 21 anos: 
I - a pena será diminuida;

II - as penas privativas da liberdade cumprir-se-ão até à maioridade, em seç̧ões separadas dos estabelecimentos destinados aos adultos.

Pr. - Omisso.

Cod. de Men. - Omisso.

Art. 112 - Tendo o agente mais de 18 anos quando fôr julgado por crime cometido antes dessa idade, o juiz aplicar-lhe-á, de acôrdo com a sua periculosidade e a gravidade e as circunstâncias do crime, as medidas referentes aos menores de 14 a 18 anos ou as penas estabelecidas para os maiores, com observancia do disposto no artigo anterior.

Pr. - Omisso.

Cod. de Men. - Omisso.

\section{TITULO VII}

\section{Da ação criminal}

Art. 113 - Haverá logar a ação pública, sempre que a lei não dispuser expressamente o contrario.

$\S 10^{\circ}$ - Dependerá, todavia, a ação pública :

I - nos crimes da injuria, difamação, calúnia, cometidos contra autoridade nacional ou estrangeira:

a) de determinação do Ministro da Justiça, quando a ofensa fôr praticada contra o Presidente da República, ou qualquer dos poderes politicos ou das classes armadas coletivamente;

b) de requisição do representante diplomático junto ao governo brasileiro, quando o ofendido fôr êle proprio ou o chefe do Estado, que o acreditou;

c) de representação do ofendido, se este o houver sido, em razão do cargo, como agente ou depositario da autoridade publica;

II - nos crimes de violencia carnal e nos outros casos expressos em lei, de representação do ofendido ou de quem tiver qualidade para representá-lo. 
$\S 2 .^{\circ}$-- A determinação, a solicitação e a representação a que alude o $\$ 1 .^{\circ}$, far-se-ão dentro em 3 meses contados do dia em que tiver o respectivo autor noticia do crime e de quem seja o seu agente; e tornar-se-ão irretrataveis, uma vez intentada a ação pública.

$\S 3 .^{\circ}$ - $O$ ofendido, ou quem tiver qualidade para representá-lo, poderá intentar ação privada nos crimes de ação pública, se esta não o fôr no prazo da lei.

Art. 114 - Não se admitirá a ação privada, mediante queixa do ofendido ou de quem tiver qualidade para representá-lo, senão nos casos expressos.

$\S 10^{\circ}$ - No caso de morte do ofendido ou de ter sido ele declarado ausente por decreto judicial, o direito de oferecer a queixa ou de prosseguir na ação caberá sucessivamente, na ordem em que vão enumerados, ao cônjuge, descendente e irmão; ou, sem dependencia dessa ordem, a qualquer deles, em se tratando de injuria, difamação ou calunia irrogada a morto ou ausente.

$\S 2 .^{\circ}$ - O direito de queixa não mais poderá ser exercido:

I - quando renunciado expressa ou tacitamente;

II - quando decorridos 3 meses sobre o dia em que o respectivo titular tiver noticia do crime e de quem seja o seu agente.

$\S 3 .^{\circ}$ - Importa em renuncia tacita ao direito de queixa a prática de ato incompativel com a vontade de exercê-lo. Não se considera como tal o fato do ofendido receber a indenização do dano causado pelo crime.

$\S 4 .^{\circ}$ - A renuncia feita pelo incapaz, contra a vontade de seu representante legal, será levada em conta pelo juiz para decretar, ou não, a extinção do crime, atentos os motivos determinantes da renuncia e as condições pessoais do renunciante.

Art. 115 - Em todos os termos da ação privada será ouvido o Ministerio Público; e na ação pública poderá intervir como assistente o ofendido ou quem tiver qualidade para representá-lo.

Art. 116 - No crime de exercicio ilegal de profissão considera-se ofendido para os efeitos do art. $113 \S 3 .^{\circ}$ e da segunda parte do art. 116 o respectivo sindicato profissional. 
Pr. 13 - Salvo os casos de representação ou de queixa previstos nêste Codigo, todo o crime provocará a ação do Ministério Público para reprimi-lo. 43: A ação repressora do Ministério Público, além dos casos previstos na Parte Especial, será provocado pela representação do ofendido nos seguintes: I - lesão corporal leve; II - atentado ao pudor, violência carnal, rapto e contágio de moléstia venérea ou sifilítica; III - calúnia ou injúria contra autoridade ou funcionário público em razão de suas funções. § único - Nos casos previstos no $n^{0}$ II poderá o Ministério Público repelir a representação, quando se convencer de que seu autor obedece a motivos reprováveis. 44: Nos casos dos ns. I e II do art. precedente tratando-se de menores ou de interditos por doença mental, poderão representar pelo ofendido aqueles que forem por êles legalmente responsáveis, e na sua falta quem justificar, por suas relações de parentesco, interêsse moral na punição do culpado. Este interêsse legitíma a representação na hipotese do $\mathrm{n}^{\circ}$ III, tratando-se de calúnia e de injúria contra os mortos. 45: A representação será dispensável quando de qualquer dos crimes previstos no n. ${ }^{\circ}$ II do art. 43 resultar para o ofendido morte ou lesão corporal grave; doença mental incurável, ou de cura duvidosa ou demorada; inhabilitação permanente para o trabalho; perda de algum sentido ou da palavra. 46: Embóra as hipóteses do art. precedente não se verifiquem, da representação se prescindirá quando: por debilidade mental, ignorância ou sìmpleza não puder o ofendido ou quem por êle devesse representar avaliar em toda a sua extensão e gravidade o mal infligido; se tratar de menor ou interdito ofendido; se tratar de pessôa de condições humildes, reduzida ao silêncio por medo de seu ofensor. 47: Não obsta o direito de representação a que o ofendido de queixa, mas iniciada a ação pública, a repreșentação é irretratável. 48: $O$ direito de representar ou dar queixa extingue-se em seis mêses, a partir da $24 .^{a}$ hora do dia em que o ofendido, ou quem por êle devesse representar, tiver ciência do crime ou de quem seja o seu autor.

Cons. 40 - Haverá lugar a ação penal. $\$ 10^{\circ}$ - Por queixa da parte ofendida ou de quem tiver qualidade para representá-la; $\S 2 .^{\circ}-$ Por denúncia de qualquer pessôa nos crimes políticos e nos de responsabilidade de funcionários federais; nos crimes do art. 278 (proxenetiso) $342 \S 2 .^{\circ}$ e 346 (direitos autorais), 165 e 168 (crimes eleitorais); $\S 2 .^{\circ}$ por denúncia do Ministério Público em todos os crimes e contravenções, excetuados os de dano, que não forem contra cousas do dominio ou uso públic da União, Estados e Municípios ou em livros de notas, atos e termos, autos e atos, originais da autoridade pública, não tendo havido prisão ou flagrante; ou de violência carnal, rapto, adultério, parto suposto, em que sómente coberá procedimento por queixa da parte, salvo 
os casos dos art. 274 (se... miserável ou asilada... resultar morte, perigo de vida o ualteração grave da saúde... com abuso do pátrio poder ou autoridade de tutor, curador ou preceptor); a de injúria ou calúnia... contra particulares, cabendo... denúncia do Ministério Público, quando contra corporação que exerça atividade pública, agente ou depositário desta razão de suas funções, chefes do Estado extrangeiro ou representantes diplomáticos e ainda nos casos do art. $322 \S 3 .^{\circ}$ (ofensa não injuriosa ou caluniosa ao Presidente, soberano ou chefe de estado extrangeiro ou seu representante diplomático), dependendo... nêstes últimos casos de requisição feita por parte do respectivo Governo, e mediante ofício do Ministério da Justiça, quando se tratar... Presidente da República; os contra a propriedade literária e artística, que não...os dos arts. 342 $\S 3 .^{\circ}$ n. $^{\circ}$ e $346 ; \S 4 .^{\circ}$ - mediante procedimento dos ofícios nos crimes inafiançáveis, quando não fôr apresentada a denuncia nos prazos da lei. § 5. - - A ação pública será iniciada sob representação do ofendido se o furto se der entre parentes e afins até ao $4 .^{\circ}$ gráu civil, não compreendidos no art. 335 (que declara não ter lugar a ação entre marido, mulher, salvo separados judicialmente de pessôa, bens, ascendentes, descendentes e afins com mesmos gráus). 408: Em todos os termos da ação intentada por queixa será ouvido o Ministério Público; e nos em que o fôr por denúncia ou ex-ofício poderá intervir a parte ofendida para auxiliál-o.

Art. 117 - A ação criminal extingue-se:

I - pela morte do agente;

II - pela anistia;

III — pela prescrição;

$\S$ único -- Tambem se extingue a ação criminal:

I - pelo perdão do ofendido nos crimes em que sómente se procede mediante queixa;

II - pela retratação do agente nos crimes que a admitem;

III - pelo casamento do agente com a mulher por êle agravada em sua honra, nos crimes contra o pudor individual;

IV - pela rehabilitação do falido no juizo comercial, em se tratando do crime de falencia.

Pr. 14 - A ação criminal extingue-se: pela morte do inculpado; pela anistia; pela prescrição; pela coisa julgada. § único: São causas especiais de extinção: a retratação inequívoca do querelado nos cri- 
mes que a admitem; o casamento do ofensor com a mulher por êle agravada em sua houra; o pagamento da multa, em qualquer fase do processo, quando fôr a única pena aplicável ou, afinal, depois de aplicada, quando alternativa.

Cons. 71 - A ação penal extingue-se pela morte do criminoso; pela anistia do Congresso; pelo perdão do ofendido e pela prescrição.

Art. 118 - A anistia põe o processo em perpétuo silêncio. Não exime, porém, o agente de reparar o dano, nem o autoriza, salvo expressa disposição em contrário, a rehaver os bens confis. cados.

Pr. 15 - A anistia não compreende os crimes comuns, nem autoriza a restituição dos objetos confiscados, salvo expressa disposição em contrário.

Cons. 75 - A anistia extingue todos os efeitos da pena e põe perpétuo silêncio ao processo. $76 \ldots$ não exime o agraciado de satisfazer a indenização do dano.

Art. 119 - 0 perdão do ofendido póde ser processual ou extra-processual, e este expresso ou tácito.

$\S$ único - 0 perdão:

I - outorgado por um dos ofendidos não prejudica o direito dos outros;

II - em favor de qualquer dos partícipes a todos aproveita;

III - quando judicial, póde ser recusado pelo réo.

Cons. 77 - Nos crimes pelos quais não se pode proceder senão por queixa da parte, o perdão do ofendido extingue a ação penal, más não faz cessar a execução da sentença, se o condenado recusar aceitá-lo.

Pr. arg. 104 - A renúncia da pessôa agravada só produz efeito em relação ao renunciamento e aos seus herdeiros.

Art. 120 - A ação criminal prescreve:

I - em vinte anos, se o máximo da pena cominada abstratamente para o crime fôr a morte ou a reclusão por mais de 15 anos; 
II - em 15 anos, se fôr de mais de 10 anos até 15;

III - em 10 anos, se fôr de mais de 5 até 10 ;

IV - em 5 anos, se fôr de mais de 1 ano até 5 ; ou se o crime fôr punivel sómente com multa superior a um conto de réis;

$\mathrm{V}$ - em 2 anos, em se tratando de crime não compreendidos nos incisos anteriores ou nos seguintes;

VI - em 3 mêses, quando o crime não fôr punível senão mediante queixa do ofenåido;

$\S 10^{\circ}$ - Aumentar-se-á da metade, quando o agente fôr domiciliado ou estiver homisiado no estrangeiro, o prazo para prescrição dos crimes contra a personalidade do Estado (arts. 132 a 145 e 150 dos crimes relativos á moeda e titulos de emissão privativa do poder público e marcas oficiaes (arts. 254 a 265).

$\S 20^{\circ}$ - Reduzir-se-ão de um terço os prazos estabelecidos, com relação ao agente que na data do crime fôr maior de 18 anos e menor de 21; salvo nos casos do $\mathrm{n}^{\circ}$ VI e do $\S 1 .^{\circ}$ dêste artigo.

$\S 3 .^{\circ}$ - Para os efeitos dêstes artigos não se terá em conta senão a pena detentiva, quando cominada conjunta ou alternativamente com a pecuniária.

Pr. 16 - A ação penal prescreve: I - em 20 anos quando o máximo genérico da pena da prisão puder ser atingido; II - em 15 se o máximo específico não se fixar em menos de 10 , nem em mais de 15 anos; III - em 10 se, partindo de 5 anos, não atingir a 10 . $\S 10^{\circ}$ - Quando, com a prisão, outra pena mais branda também tiver sido prevista para o crime, diminuir-se-á de um terço o prazo da prescrição. $\S 20^{\circ}$ - Nos crimes comuns a prescrição será: I - de 3 anos quando sómente prevista a detenção ou, alternadamente, também a multa, ou, facultativamente, as duas se puderem cumular; III - de um, quando sómente prevista a multa. $\S 3 .^{\circ}-0$ exílio local não se contará na prescrição; contar-se-á, porém, a pena substitutiva.

Cons. 78 - A prescrição da ação, salvo os casos especificados nos arts. 275 (defloramento, estupro, rapto), 277 (lenocínio do marido) e 281 (adultério) é subordinada aos mesmos prazos que o da condenação. 85: ... em 1 ano quando... pena restritiva da liberdade pessoal por tempo não excedente de 6 mêses; 2, quando mais de 6 mêses e menos de 1 ano; 4, por 1 até 2 anos; 6 , mais de 2 até 3,8 , mais de 3 até 4 ; 10 , mais de 4 até $8 ; 12$, mais de 8 até $10 ; 16$, mais de 10 até $12 ; 20$, mais de 12. Em 2 anos, falência e injúria e calúnia pela imprensa. 
Em 10, crimes contra o livre exercício dos direitos políticos. Em tempo algum, moeda falsa, contra a Constituição, livre exercício de direitos políticos e conspiração, quando o réo domiciliado ou homisiado no estrangeiro. Regula-se a prescrição da ação penal pelo máximo de pena abstratamente cominada ou pela que fôr pedida no libelo ou pela que fôr imposta em sentença de que sómente o réo houver recorrido. 0 decr. 22.494 de 33 reduz à metade os prazos para os deliquentes de 18 a 21 anos.

Art. 121 - 0 prazo de prescrição da ação criminal contar-se-á do dia em que o crime fôr cometido.

$\S 10^{\circ}$ - Reputar-se-ão cometidos :

I - o crime tentado, no dia em que fôr praticado o último ato constitutivo do começo de execução;

II - o crime permanente, continuado ou sucessivo, no dia em que cessar a atividade criminosa do agente;

III - o crime, cuja punibilidade estiver subordinada a uma sondição, no dia em que esta se verificar.

$\S 20^{\circ}$ - Em se tratando do crime de falencia, o prazo correrá do dia em que esta fôr encerrada no juizo comercial ou cumprida a concordata.

Pr. 17 - A prescrição começará a correr da $24 .^{\text {a }}$ hora do dia em que se tiver cometido o crime, ou produzido o resultado com o qual se eonsumar, ou praticado o último ato da série que o constituir.

Cons. 79 - A prescrição da ação resulta exclusivamente do lapso de tempo decorrido no dia em que o crime fôr cometido.

Art. 122 - Não correrá a prescrição da ação criminal :

I - enquanto pendente de solução, em outro processo, questão a que estejam subordinados o seu início ou o seu prosseguimento, II -- enquanto o agente estiver cumprindo pena no estrangeiro.

Pr. 17 - Quando a sentença criminal depender de sentença ou diligência noutro juizo, a prescrição começará a correr do dia que passar em julgado a primeira ou a segunda fôr publicada em cartório.

Cons.: Omissa. 
Art. 123 - A prescrição da ação criminal interrompe-se:

I - pela apresentação da denúncia ou da queixa;

II - pela pronúncia;

III - pela decisão confirmatória da pronúncia;

IV - pela sentença condenatoria, de que caiba recurso ordinario;

$\nabla$ - pela reincidencia genérica, se o novo crime fôr punido com reclusão, ou pela reincidencia especifica ou reiterada.

$\S$ único - Interompida a prescrição, o prazo passará a correr integralmente do ato que a interromper; e, se fôrem vários os atos interruptores, do dia em que o último dêles se verificar.

Pr. 17 único - A prescrição interrompe-se por qualquer ato judicial inculpando o prescribente, e, no crime de calúnia, pela exceção da verdade.

Cons. 79 - Interrompe-se pela pronúncia. A prescrição da ação penal que recomeça a correr da pronúncia interrompe-se pelo despacho que a esta confirma e bem assim pela sentença condenatória recorrivel. 81: A prescrição... interrompe-se pela reincidência.

Art. 124 - A ação criminal prescreverá, não obstante o disposto nos arts. 122 e 123, quando excedidos de mais da metade os prazos estabelecidos no art. 120 .

Pr. - Omisso.

Cons. - Omisso

Art. 125 - A interrupção e a suspensão da prescrição da ação criminal:

I - não produzirão efeito em relação ans outros partícipes, quando se refiram sómente a um dêles;

II - mas, embóra digam respeito a um só dos erimes conexos, que furem objéto do mesmo procedimento, produzirão efeito em relação uos outros.

Pr. - Omisso.

Cons. - Omisso. 
Art. 126 - A causa extintiva do crime, que seja pressuposto, ou elemento constitutivo, ou causa de agravação de outro, não se estende a este último. Tambem a extinção de um dos crimes conexos não exclue, quanto aos restantes, a agravação da pena resultante da conexão.

Pr. - Omisso.

Cons. - Omisso.

Art. 127 - A condenação extingue-se :

I - pela morte do condenado;

II - pela anistia;

III - pelo indulto.

$\S 10^{\circ}$ - Tambem se extingue a condenação:

I - pelo perdão do ofendido, nos crimes em que sómente se procede mediante queixa;

II - pelo casamento do condenado por crime contra o pudor individual com a mulher por ele agravada em sua honra;

III - pelo cumprimento das condições impostas na sentença que suspender a execução da pena ou conceder o livramento condicional;

IV - pela prescrição da pena.

$\S 20^{\circ}-0$ perdão outorgado a um dos partícipes extingue a condenação aos outros.

§ $30^{\circ}$ - A extinção da condenação não importa na das obrigações civis decorrentes do crime; salvo renúncia expressa do ofendido nos crimes em que se admite o perdão.

$\S 4 .^{\circ}$ - Prevalecerá a causa extintiva do crime, quando concorrer com outra extintiva da condenação, embóra lhe seja posterior.

Pr. 126 - A condenação extingue-se: I - pela morte do condenado; II - pelo cumprimento da pena; III - pela anistia; IV pelo indulto; V - pela prescrição da pena; VI - pelo casamento do ofensor com a mulher por ele agravada em sua honra; VII - pelo perdão do ofendido, observadas, as condições legais na sua admissibilidade; VIII peìa suspensão na execução da pena ou pelo livramento condicional, quando cumpridas as suas condições. 13): Extinta a condenação não se extingue a obrigação de reparar o dano, mas da mesma se poderá no 
perdão, notado ou em parte, exonerar o responsavel. Dado a um dos co-autores, o perdão e extingue a condenação dos demais.... quanto á reparação do dano... só aproveita aos nominalmente contemplados, na proporção em que o tiverem sido.

Cons. 73 - A condenação extingue-se pelas mesmas causas (da extinção da ação) e mais pelo cumprimento da sentença, pelo indulto do poder competente e pela rehabilitação. 74: As incapacidadaes pronunciadas pela condenação cessam em consequencia do indulto ou graça. 75: A anistia extingue todos os efeitos da pena e põe perpetuo silencio ao processo. 76: A anistia e a remissão das penas pelo indulto ou graça não eximem o agraciado de satisfazer a indenização do dano.

Art. 128 - Prescrevem:

I - no prazo de 30 anos a pena de morte e de reclusão por 20 anos ou mais;

II - em prazo correspondente ao dobro do tempo, pelo qual fôr imposta, a pena privativa da liberdade inferior a 20 anos;

III - em 3 anos, quando não exceder de 1:000\$, em 6 anos, quando não exceder de 5:000\$, e, quando exceder de 5:000\$ em 10 anos, a pena de multa.

$\S 10^{\circ}$ - Aumentar-se-á da metade o prazo estabelecido no II para a prescrição da pena, não podendo, porém, êle exceder de 20 anos, quando o condenado fôr criminoso reincidente, habitual ou por tendencia.

$\S 20^{\circ}$ - Diminuir-se-á de um terço o prazo se fôr o condenado maior de 18 anos e menor de 21.

$\S 4 .^{\circ}$ - Prescrevem com a pena mais grave as mais leves.

Pr. 138 - A pena de prisão prescreve, ainda quando convertida em detenção: em 35 anos a de 30; em 25 a de mais de 10; em 15 a de mais de 5; em 8 a de mais de 3 ; em 5 a de 1 até 3 anos. $\S$ único - Em se tratando de criminosos por índole, reincidentes, incorrigíveis ou profissionais, não basta para a prescrição do decurso de tempo; também é preciso provar o prescribente haver mantido bom comportamento durante todo êle. 138: A multa prescreve: em 1 ano a qeu não exceder de 500\$000; em 3 a que não exceder de 1:000\$0000; em 5 a que não exceder de 3; em 7 a que não exceder de 5, prescrevendo em 10 as demais. 140: A pena de detenção prescreve pelo tempo por que tiver sido imposta, aumentada de metade. 141: Com a pena principal prescrevem as accessórias e com a pena mais grave as mais leves. Na 
co-autoria o efeito da prescrição da pena é restritamente pessoal a cada um dos condenados, salvo no caso de perdão.

Cons. 78 - A prescrição da ação... é subordinada aos mesmos prazos que a da condenação: 83: A ação criminal e a condenação, nos crimes a que a lei infligir exclusivamente pena pecuniária, prescreverá em 1 ano a contar... da condenação. 84: A condenação a mais de uma pena prescreve no prazo estabelecido para a mais grave. 85:.. em 10 anos a pena de interdição; em 3 a de suspensão do emprego; em 10 a de perda do emprego. A punição de interdição, de suspensão ou perda do emprego começará a correr depois de cumprida a pena restritiva da liberdade... a que forem adjetas ou de que forem efeito.

Art. 129 - 0 prazo da prescrição da pena contar-se-á:

I - do dia em que passarem em julgado

a) a sentença condenatória;

b) a revogação da suspensão condicional da execução da pena;

II - do dia em que deveria começar a cumpríla o condenado, em seguida ao cumprimento de outra anterior.

Pr. 142 -A prescrição da pena começará a correr do dia em que a sentença passar eln julgado, ou do em que se revogar a suspensão da execução da pena ou do (?) livramento condicional, ou do, em que por qualquer outro modo, se interromper a execução, salvo quando o tempo da interrupção se computar na pena. Se o condenado já cumpria pena, a prescrição começará do dia em que a segunda pena deva ser cumprida.

Cons. 80 - A prescrição da condenação começa a correr do dia em que passar em julgado a sentença ou daquelle em que fôr interrompida de qualquer modo a execução.

Art. 130 - Sem prejuizo do disposto no $§ 2^{\circ}$ do art. 131 , não correrá a proscrição da pena, enquanto suspensa a execução condicional da sentença.

Pr. - Omisso.

Cons.: $51-\S 50^{\circ}-$ Durante o prazo da suspensão não correrá prescrição.

Art. 131 - Interrompe-se a prescrição da pena, passando a prazo a correr do dia da interrupção, como se nunca houvesse começado : 
1 - pelo início da execução;

II - pela captura do condenado para cumpríla;

III - pela reincidencia, nos termos do art. $123 \mathrm{n} . \mathrm{V}$.

$\S 10^{\circ}$ - Interrompe-se tambèm pela evasão do condenado e pela revogação do livramento condicional; mas o prazo se regulará então pelo remanescente da pena.

$\S 20^{\circ}$ - Em qualquer hipótese haver-se-á por consumada a prescrição, quando excedido de mais da metade o prazo estabelecido de acordo com o art. 128.

Pr. 143 - A prescrição da pena interrompe-se pelo início da execução; pela captura do condenado para cumprí-la; pela perpetração de novo crime. 144: Do dia em que o condenado se tiver evadido, nova prescrição começará a correr, regulado o seu prazo, pelo tempo da pena restante.

Cons. 80 e 81 - Interrompe-se pela prisão do condenado... pela reincidencia. Se o condenado, em cumprimento da pena, evadir-se, a prescrição começará a correr novamente do dia da evasão. 


\section{LIVRO II}

\section{PARTE ESPECIAL}

TITULO I

\section{Dos crimes contra a personalidade do Estado}

\section{Capitulo I}

\section{Dos crimes contra a Nação Brasileira}

Art. 132 - Violar a soberania territorial do Estado, praticando indebitamente ou favorecendo a prática indébita, no territorio nacional, de áto de jurisdição de Estado estrangeiro.

Pena - reclusão por 5 a 15 anos.

Pr. 380 - Aqueles que penetrarem armados no territorio nacional, para nele jurisdicionalmente proceder em nome de soberania estranha, serão punidos com prisão até 3 anos.

Cons.: Omissa.

Art. 133 - Remover, destruir ou danificar, de modo a torná-lo irreconhecivel, marco ou sinal indicativo de fronteira nacional.

Pena - reclusão por 1 a 5 anos.

$\S$ Unico - Se o crime fôr culposo.

Pena - detenção por 6 meses a 2 anos ou multa de 2 a $15: 000 \$ 000$.

Pr. - Omisso.

Cons. - Omisso. 
Art. 134 - Abandonar ou entregar de fato ao inimigo, sem embargo de dispôr de meios sufficientes de defesa, qualquer porção do territorio nacional ou de territorio estrangeiro ocupado por forças nacionaes, ou cousa sobre que tenha a Nação dominio ou posse, que ao agente cumprisse defender.

Pena - reclusão por 5 a 15 anos.

Pr. 357 - Aquele que, ainda dispondo de meios suficientes de defesa, abandonar ou entregar ao inimigo, qualquer porção do territorio nacional ou do territorio estrangeiro ocupado por forças nacionaes ou a posição que lhe cumpria defender, será punido com prisão por 3 a 9 anos.

Cons. $87 \S 1 .^{\circ}$ - Entregar de fato ao inimigo interno ou externo qualquer porção do territorio possuido ou ocupado pela nação, ou cousa sobre que a mesma tenha dominio ou posse, dispondo de meios de defesa e resistencia - 5 a 15 anos.

Art. 135 - Provocar diretamente e por fatos nação estrangeira a declarar guerra ou mover hostilidades contra o Brasil ou a intervir em questão que respeite á soberania nacional.

Pena - reclusão por 3 a 9 anos.

§ unico - A pena será de reclusão por 5 a 15 anos, se, para evitar qualquer dessas consequencias, o Brasil tiver de fazer sacrificio moral ou material.

Pr. 382 - Aquele que diretamente e por fatos, provocar alguma nação a cometer hostilidades contra o Brasil, ou a declarar-lhe guerra, será punido com prisão até 3 anos. Se as hostilidades se iniciarem, a guerra se declarar, ou só se frustrar com grave sacrificio material ou moral da nação, o minimo da prisão será de 5 anos.

Cons. $88, \S 2 .^{\circ}: \mathrm{Si}$, para não se verificar a guerra, declarada em consequencia da provocação, a nação tem de fazer algum sacrificio, em detrimento a essa integridade ou nos seus interesses - 5 a 1 5anos.

Art. 136 - Expôr o Brasil a perigo de guerra, praticando, sem autorização do governo, atos de hostilidade, no territorio nacional ou fóra dele, contra nação estrar ¿geira.

Pena - reclusão por 3 a 9 anos. 
$\S 10^{\circ}$ - Se o fato determinar ruptura de relações diplomaticas, represália ou retorsão.

Pena - reclusão por 4 a 10 anos.

$\S 2 .^{\circ}$ - Se do fato resultar a guerra.

Pena - reclusão por 5 a 15 anos.

Pr. - Omisso.

Cons. 90 - Cometer, sem ordem ou autorização do governo, hostilidades contra subditos de outra nação, de maneira que se comprometa a paz ou se provoquem represálias.

Art. 137 - Violar territorio estrangeiro, sem autorização do governo, para praticar ato de jurisdição em nome do Brasil.

Pena - detenção ou reclusão por 1 a 3 anos.

Pr. 401 - Aqueles que partindo de territorio brasileiro, invadirem armados o de paiz visinho, ou, tendo o invadido por fronteira estranha, nele, á falsa fé, praticarem atos oficiaes em nome da soberania brasileira, serão punidos com detenção até 2 anos.

Cons. 102: Entrar jurisdicionalmente em paiz estrangeiro sem autoridade legitima -6 meses a 4 anos.

Art. 138 - Entrar, sem autorização do Governo, em entendimento com alguma nação estrangeira, para empenhar ou realizar atos tendentes a empenhar o Brasil á neutralidade ou á guerra.

Pena - reclusão por 3 a 9 anos.

Pr.: Omisso.

Cons. Omissa.

Art. 139 - Violar tratado concluido com outra nação, ou trégua ou armisticio acordado com potencia ou forças inimigas, ou solvo-conduto regularmente expedido.

Pena - detenção por 6 meses a 3 anos.

Pr. 326 - Será punido com prisão até 3 anos aquele que, diretamente e por fatos, se opuzer.. 3) á execução das convenções e tratados internacionaes concluidos com a União. 
Cons. 98 - Violar tratados legitimamente feitos com as nacões estrangeiras - 6 meses a 4 anos.

Art. 140 - Engajar-se brasileiro, como combatente ou em outra qualidade, em força militar de nação que esteja em guerra contra o Brasil.

Pena - reclusão por 5 a 10 anos.

$\S 10^{\circ}$ - A pena será de reclusão por -10 a 20 anos, se o agente tiver posto de oficial nas fileiras inimigas; e de 20 a 30 anos, se nelas exercer posto de comando superior ou direção.

$\S 20^{\circ}$ - Não será punivel aquele que praticar o ato, constrangido pelo inimigo, em cujo territorio se encontre no decurso das hostilidades.

Pr. 386 - O brasileiro que tomar armas contra a nação, debaixo de bandeira inimiga, ou que, nas forças inimigas arrolado, não as abandonar ao rompimento das hostilidades, será punido com prisão: 1) por 2 a 5 anos, se nas fileiras inimigas era simples soldado ou prestava serviços auxiliares de campanha; 2) por 3 a 10 anos, se tinha posto de oficial; 3) por 5 anos, no mínimo, se exercia posto de comando ou de direção tecnica.

Cons. 89 - Tomar armas o cidadão brasileiro contra a Repúplica, debaixo de bandeira inimiga -2 a 4 anos.

Art. 141 - Serão punidos :

I - com reclusão por 10 a 25 anos aquele que entrar em entendimento com o inimigo para lhe favorecer as operações militares ou prejudicar as do Brasil;

II - com reclusão por 5 a 15 anos aquele que der asilo, auxilio ou evasão a espião ou emissario do inimigo, uma vez que o conheça como tal;

III - com reclusão por 5 a 15 anos e multa de 5 a $30: 000$ \$000 aquele que, por si ou interposta pessoa:

a) fornecer ao inimigo armas, munições ou outra especie de material bélico, gente, provisões ou meio de transporte;

b) participar, como subscritor, agenciador ou de outra fórma, de emprestimo ou contribuição em favor do inimigo. 
IV - com reclusão por 2 a 5 anos e multa de 5 a $30: 000 \$ 000$ aquele que, direta ou indiretamente, comerciar com súbdito de Estado inimigo, qualquer que seja a sua residencia, ou com pessoa residente no territorio desse Estado; ou desviar ou sonegar bens pertencentes a súbditos de Estado inimigo, sequestrados ou sujeitos a sequestro;

$\mathrm{V}$ - com detenção ou reclusão por 1 a 3 anos, aquele que der ou facilitar a evasão a prisioneiro de guerra;

VI - com reclusão, por 1 a 5 anos, ou, no caso de entendimento com o inimigo, por 3 a 15 anos, aquele que, em tempo de guerra, propalar noticias falsas, exageradas ou tendenciosas, que, provocando alarme ou depressão do espirito público, possam diminuir a resistencia da nação;

VII — com reclusão por 3 a 10 anos e multa de 15 a $30: 000 \$ 000$, penas que serão dobradas se o crime fôr cometido em consequencia de entendimento com o inimigo, aquele que em tempo de guerra, empregar meios tendentes a desvalorizar a moeda ou a influir no mercado de titulos ou valores publicos ou particulares, de fórma a pôr em perigo a resistencia nacional;

VIII - com reclusão por 3 a 10 anos e multa do triplo do valor da prestação, no caso de dolo, penas que serão reduzidas á metade no caso de culpa, aquele que, em tempo de guerra, não executar contrato de fornecimento de cousas ou serviços para atender ás necessidades das forças armadas ou da população.

$\S$ unico - Incorrerão nas penas do n. VIII os sub-contratantes, agentes ou empregados que, infringindo as suas obrigações contratuaes, tenham dado causa á inexecução do contrato de fornecimento.

Pr. 383 - Será punido com prisão por 3 a 9 anos, ou no caso de culpa com detenção até 1 ano, aquele que, estando o Brasil em guerra ou na iminencia de guerra: 1) fornecer ao inimigo, declarado ou previsto, dinheiro, gente, armas, munições, provisões, meios de transporte, de comunicação ou agressão. 2) dar entrada e auxilio a espião ou a emissarios inimigos conhecendo-os como taes, que os açoitar, ocultar ou proteger, quando não o faça por dever de parentesco, com o único fim de subtraílos á ação da autoridade. 385: Aquele que em tempo de guerra civil ou estrangeira, não executar intencionalmente contrato de fornecimento militar, ou lhe não cumprir lealmente as clausulas, será punido com prisão até 5 anos, ou, se sómente responder por culpa, com 
detenção ou multa. Nas mesmas penas incorrerão os sub-contratantes, agentes ou empregados, a cuja falta se deva a inexecução ou a desleal execução do contrato. 394: O brasileiro que no paiz ou fóra dele, por si ou interposta pessôa, agenciar, favorecer ou subscrever empréstimo de nação estrangeira em guerra ou na iminencia de guerra com o Brasil, será punido com prisão até 3 anos e com multa. 396: O brasileiro que em tempo de guerra, por si ou por interposta pessôa, comerciar com subditos de Estado inimigo ou com pessôas residentes ou domiciliadas em territorio inimigo, será punido com prisão até 3 anos e com multa.

Cons. $87 \S 2 .^{\circ}$ - Auxiliar nação inimiga... fornecendo-lhe gente, armas, dinheiro, munições e meios de transporte - 5 a 15 anos.

Art. 142 - Punir-se-á com reclusão por 3 a 10 anos aquele que :

I - subtrair, embora temporariamente, ou falsificar ou destruir no todo ou em parte, documento concernente á segurança ou a interesse politico, interno ou internacional, do Brasil.

II - revelar, ou concorrer para que se revele ao público, ou comunicar, ou concorrer para que se comunique a governo estrangeiro, fato que constitua segredo de Estado;

III - tiver no Brasil serviço secreto de informações ou espionagem no interesse de Estado estrangeiro;

IV - sem permissão da autoridade competente :

a) fotografar, desenhar ou levantar planta de fortificação, navio ou aeronave de guerra, estabelecimento, estrada ou obra militares ;

b) reproduzir ou publicar taes documentos;

c) sobrevoar ou introduzir-se, munido de meios idoneos á pratica de um desses atos, em qualquer dos mencionados logares ou em zona de acesso interdito ao publico, no interesse da defesa nacional.

$\S 10^{\circ}$ - Destruir ou inutilizar, no todo ou em parte, embora temporariamente, navio ou aeronave de guerra, estrada, comboio, ou qualquer estabelecimento ou obra militar.

Pena - reclusão por 5 a 15 anos, elevada ao dobro se o crime tiver prejudicado as operações militares ou a preparação ou eficiencia bélica do Estado. 
$\S 20^{\circ}$ - Obter ou divulgar noticia, que, ernbora não constitua segredo de Estado, tenha a publicação proíbida pelo Governo da União.

Pena - detenção ou reclusão por 1 a 3 anos.

$\S 3 .^{\circ}$ - Concorrer culposamente para a pratica de qualquer dos crimes definidos neste dispositivo.

Pena - a do crime, com a redução de um a dois terços.

$\S 4 .^{\circ}-$ Aumentar-se-ão as penas cominadas :

I - se o crime fôr cometido em tempo de guerra;

II - se dele resultar prejuizo para a preparação ou a eficiencia bélica do Eistado ou para as operações militares.

Pr. 392 - Será punido com prisão até 5 anos aquele que: 1) revelar, ou concorrer para que se revele ao publico, comunicar ou concorrer para que se comunique a governo estrangeiro, segredo de Estado que no interesse da Nação, lhe cumpria guardar; 2) - destruir, falsificar, sumir, ou subtrair titulos, documentos ou meios de prova relativos a questões entre o Brasil e Estado estrangeiro, assim prejudicando os interesses nacionaes. 389: Será punido com detenção ou multa em tempo de paz e com prisão até 3 anos em tempo de guerra aquele que, sem permissão da autiridade competente: 1) - tirar fotografias, esboço ou desenhos, ou levantar plantas de fortificações, navios e aeronaves de guerra, estabelecimentos, estradas e obras militares; 2) - se introduzir ou fôr surpreendido nesses logares, ou em zonas de terra, do ar ou do mar; compreendidos os rios e lagos, de acesso reservado, ou nas suas imediações, na posse injustificada dos meios idoneos á prática dos atos definidos no n..$^{\circ}$. Os aparelhos, instrumentos, máquinas e papeis, que se relacionem com o crime serão confiscados. 393: Aquele que com o intuito de delação a governo estrangeiro, de publicidade ou de lucro, procurar senhorar-se de segredo de Estado que, uma vez divulgado, possa expôr a Nação a perigo, sacrificio ou dano, será punido com prisão até 3 anos. Se o crime tiver sido cometido estando o Brasil em guerra ou na iminencia de guerra, a prisão será por 2 a 5 anos.

Cons. $87 \S 3 .^{\circ}$ - Revelar a nação inimiga, ou a seus agentes, segredos politicos ou militares, concernentes á segurança e á integridade da patria; comunicar ou publicar documentos, planos, desenhos e outras informações com relação ao material de guerra, ás fortificações e operações militares da Republica ou de nações aliadas, quando operarem contra inimigo comum -5 a 15 anos. 
Art. 143 - Punir-se-á :

I - com detenção por 6 meses a 1 ano, aquele que, em tempo de paz, der asilo ou transporte a desertor, conhecendo-o como tal; e com reclusão por 3 a 9 anos, aquele que o fizer em tempo de guerra;

II - com detenção ou reclusão por 1 a 3 anos aquele que, em tempo de paz, sem autorização do governo, aliciar gente para serviço militar em paiz estrangeiro; e com reclusão por 3 a 9 anos aquele que, em tempo de guerra, o fizer.

Pr. 390 - Será punido com detenção por 1 a 3 meses ou com multa aquele que... der asilo ou transporte a insubmissos e desertores, como taes os conhecendo. 383: Será punido com 3 a 9 anos ou no caso de culpa com detenção até 1 ano aquele que, estando o Brasil em guerra ou na iminencia de guerra.. cooperar com o inimigo:

...6). .. procurando deteriorar ou destruir, deteriorando meios de comunicação e informação, instalações e objetos a serviço do Governo ou das forças nacionaes; 7). rios, estradas, pontes, viadutos, tuneis, vias ferreas, carros, máquinas, locomotivas e quasquer meios de comunicação terrestre ou aereo, fluvial ou maritimo; 8)... impedindo ou perturbando a exploração ou funcionamento de estabelecimentos, fabricas, usinas, culturas, minas, ou depositos naturaes, necessarios ao abastecimento ou aprovisionamento das forças combatentes, ao bem estar da população civil ou á economia nacional; 9)... usinas de fabricação ou geradoras de energia elétrica, seus reservathorios, barragens, represas, material, redes e instalaçōes; 10)... poluindo, envenenando ou destruindo pontes, rios e reservatorios d agua, que sirvam ao abastecimento da população ou das forças nacionaes; 11).. provocando incendios, explosões e inundações, com o fim de implantar a desorientação e o terror; 12)... monopolisando, retendo ou encarecendo gêneros alimenticios; 13)... provocando motins, insurreições e levantes ou incitando á deserção.

Cons.: Omissa.

Art. 144 - Prejudicar o interesse nacional, afastando-se, em negociação com Estado estrangeiro, das instruções recebidas.

Pena - reclusão por 2 a 6 anos.

$\S$ único - A pena será de detenção por 1 a 3 anos, se o crime fôr cometido culposamente.

Pr. 392 - Será punido com prisão até 5 anos aquele que.. 3) como delegado ou representante do Brasil, em negociações com Estado estran- 
geiro, se afastar em detrimento da Nação, das instruções recebidas. A pena será a de detenção até 1 ano, no caso de culpa.

Cons. 101 - Comprometer em qualquer tratado ou convenção, a honra, a dignidade ou o interesse da Nação; tomar compromissos em nome dela ou de seu governo, sem estar devidamente autorisado - 1 a 6 anos.

Art. 145 - Vilipendiar, por ato ou palavra, em logar público ou aberto ou exposto ao público, a Nação brasileira, ou a bandeira ou as armas do Brasil, ou a letra ou a música do hino nacional.

Pena - detenção por 6 meses a 2 anos.

§ unico - A pena será de reclusão por 1 a 3 anos, se o vilipendio da bandeira nacional consistir em publicamente destrui-la ou conspurcá-la.

Pr. 398 - Aquele que em público, acintosamente assumir para com a bandeira e o hino nacional atitude ofensiva ao sentimento popular, será punido com detenção até 1 mês e com multa. A pena será de prisão até 1 ano, quando acintosamente se tiver em público dilacerado, queimado ou conspurcado a bandeira nacional.

Cons. 100: Dilacerar, destruir ou ultrajar um lugar público, por menosprezo ou vitifundio... a bandeira nacional -6 meses a 1 ano.

\section{Capitulo II}

\section{Dos crimes contra Estados estrangeiros}

Art. 146 - Violar as imunidades de chefe de Estado estrangeiro, ou de representante diplomático junto ao governo do Brasil, ou ultrajar qualquer deles, publicamente.

Pena - detenção por 6 meses a 2 anos.

Pr. 401 - Aquele que, em territorio brasileiro, atentar contra a vida de chefe de Estado estrangeiro, agredi-lo ou ultrajá-lo em público,-será punido com as mesmas penas que se lhe aplicariam se a vitima fosse o presidente da República. 402: Aquele que ultrajar Estado estrangeiro, na pessôa de seu embaixador ou ministro acreditados no Brasil, ou membro de seu governo que, em caráter oficial, se encontre no paiz será punido com detenção até 1 ano. $\S$ un. Na mesma pena incorrerá aquele que atentar contra a imunidade das legações e embaixadas. 
Cons. 99 - Violar as imunidades dos embaixadores ou ministros estrangeiros - 1 a 2 anos.

Art. 147 - Vilipendiar em logar público ou aberto ou exposto ao público a bandeira ou outro emblema de Estado estrangeiro, em paz com o Brasil.

Pena - detenção por 6 meses a 2 anos.

Pr. 403 - Aquele que, pública e acintosamente, arrancar a bandeira, os distintivos e côres emblemáticas da soberania de nação em paz com - Brasil, da séde de seus consulados, legações e embaixadas, ou que tendo-os em seu poder, os destruir, dilacerar ou conspurcar, será punido com as penas cominadas no art. 398 (bandeira nacional).

Cons. 100 - Dilacerar, destruir ou ultrajar em logar público, por menospreso ou vilipendio, a bandeira ou qualquer outro simbolo de nacionalidade de alguma nação estrangeira. 6 meses a 1 ano.

\section{Capitulo III}

\section{Dos crimes contra os direitos políticos do cidadão.}

Art. 148 - Impedir alguem com violencia, ameaças ou fraude, de exercer direito politico, ou de exercê-lo de acordo com a vontade própria.

Pena - detcnção por 1 a 3 anos.

$\S$ unico -- Regular-se-ão por lei especial os crimes eleitorais.

Pr. Omisso.

Cons. (arts. 165 e s.): reproduz os arts. 183 e 184 do codigo eleitoral.

\section{Capitulo IV}

\section{Disposições comuns}

Art. 149 - Para os efeitos da lei penal, entende-se tambem por tempo de guerra o periodo de iminencia de guerra, uma vez que esta sobrevenha.

Pr. Omisso.

Cons. Omissa. 
Art. 150 - Regular-se-ão por lei especial os crimes contra a organização politica e social do Estado.

Pr. Omisso.

Cons. Omissa.

\section{TITULO II}

\section{Dos crimes contra a administração pública}

\section{Capitulo I}

\section{Dos crimes praticados por funcionarios contra a administração em geral}

Art. 151 - Punir-se-á com reclusão por 2 a 12 anos e multa de 2 a 30:000\$000 o funcionario público:

I - que se apropriar, ou subtrair, ou distrair, ou consentir que outrem subtráia ou distráia dinheiro, titulo ou outra cousa movel, pública ou particular, de que, em razão do cargo, o agente tiver a exação, administração ou custódia;

II - que, em beneficio proprio ou alheio, concorrer com áto do cargo ou induzir alguem a concorrer com áto dessa natureza. para a prática do crime;

III - que embora não tenha a exação, administração ou custódia da cousa subtraída ou distraída, cometer o crime, valendo-se da circunstancia de pertencer á repartição, em que ela se encontre, ou de, em razão do cargo, ser-lhe facil o ingresso em tal logar.

$\S 10^{\circ}$ - A pena será de detenção ou reclusão por 1 a 3 anos e multa de 1 a $5: 000 \$ 000$, se o funcionario concorrer culposamente para o crime cometido por outrem.

$\S 2 .^{\circ}$ - Diminuir-se-á, em qualquer hipótese, a pena, verificado, antes da condenação, o ressarcimento do dano.

$\S 3 .^{\circ}$ - Incorrerá nas mesmas penas quem tiver distraído ou subtraído a cousa, embora não seja funcionario público. 
Pr. 344 - O funcionário público ou encarregado de serviço publico que em razão do cargo ou serviço tiver sob guarda ou deposito, arrecadação ou administração, cousas, bens, valores e dinheiros do Estado ou de particular, e deles se apropriar, subtraí-los, extraviá-los ou consumi-los, ou por culpa der ensejo a que outrem o faça, será punido com prisão: 1) por 1 a 5 anos, se o prejuizo não passar de 10:000\$000; 2) por 2 a 6 anos, se não passar de 100:000\$000; 3) por 3 anos, no mínimo, se ultrapassar esta importancia. Para que se tenha por ultrapassada qualquer das quantias acima fixadas, não serão computadas no prejuizo as frações de $100 \$ 000$. Em qualquer hipotese a multa será cumulada. § un. Embora não se verifiquem todas as condições acima especificadas, este artigo será aplicavel desde que o inculpado: 1) pertença á repartição em que se tiver cometido o peculato; 2) nela em razão do cargo ou função tenha facil ingresso; 3) exerça cargo ou função que particularmente respeite ás rendas e dinheiros públicos. 346: Quando o ressarcimento no peculato ocorrer antes da sentença, a pena, sem prejuizo da interdição adequada, será livremente atenuada; quando ocorrer depois, conceder-se-á o livramento condicional.

Cons. 221 - 0 funcionário público que se apropriar, subtrair, distrair, ou consentir que outrem subtraia dinheiro, documentos, titulos de credito, efeitos, gêneros e quasquer outros bens moveis, públicos ou particulares, dos quaes tenha a guarda, o depósito, a arrecadação ou administração, em razão do cargo, seja este remunerado ou gratuito, permanente ou temporario, será punido: a) se o prejuizo fôr infexior a 10:000\$000, com 2 a 6 anos... e multa de $10 \% \ldots$ b) se o prejuizo fôr igual ou superior a $10: 000 \$ \ldots 4$ a 12 anos... e multa de $15 \%$... $\S$ un. Quando o prejuizo causado versar sobre objéto ou valor não conhecido ou instavel, o juiz. mandará proceder á avaliação... 222: Quando os fatos criminosos previstas no art. antecedente forem cometidos por funcionário público que não tenha a guarda e deposito, a arrecadação ou administração da cousa subtraida ou distraida, mas pertença á repartição em que ela se achava ,ou disponha, em razão de seu cargo, da facilidade de ingresso na mesma repartição - reduzido a $1 / 6$ o tempo da prisão. $\S$ un. Nas penas do art. 221, incorrerá ainda o funcionário público que, no seu interesse ou no de outrem, concorrer com ato do oficio ou emprego, ou usar de sua qualidade, induzindo outrem a concorrer com esse áto para que sejam distraidos ou subtraidos documentos, efeitos, valores e quaesquer outros bens moveis pertencentes á União, aos Estados, ás Municipalidades e Prefeituras ou porque estes devam responder. a) Se se provar que o funcionário agiu sem dolo, mas com imperícia ou negligencia - suspensão 6 meses a 2 anos, multa de $15 \%$. b) - No caso da letra a não haverá imposição de penas se fôr ressarcido o prejuizo causado. 
Art. 152 - Prevalecer-se, no exercicio da função pública, de erro alheio, para receber ou reter indevidamente, em proveito proprio ou de terceiro, dinheiro ou outra utilidade.

Pena - reclusão por 1 a 3 anos e multa de 1 a $5: 000 \$$.

Pr. 345 - 0 funcionário público que, no exercicio do cargo, aproveitando-se do erro de alguem, indebitamente receber ou retiver para si ou para outrem dinheiro ou qualquer outra utilidade, será punido com prisão até 3 anos e com multa.

Cons. Omissa.

Art. 153 - Punir-se-á :

I - com reclusão por 2 a 10 anos e multa de 2 a $20: 000 \$ 000$, o funcionario que, abusando do cargo, constranger alguem a dar ou prometer indebitamente dinheiro ou outra utilidade ao proprio agente ou a terceiro;

II - com reclusão por 1 a 5 anos e multa de 1 a 10:000\$000 o funcionário que induzir alguem a dar ou prometer indebitamente, ao proprio agente ou a terceiro, dinheiro ou outra utilidade;

III - com detenção por 6 meses a 2 anos ou multa de 1 a 5:000\$000 ou ambas cumulativamente, o funcionário que:

a) exigir do contribuinte, direta ou indiretamente, imposto, taxa ou emolumento, que saiba não ser devido, no todo ou em parte;

b) empregar na cobrança meio vexatorio ou gravoso que a lei não autorize.

$\S$ unico - Dobrar-se-ão as penas, no caso da letra $a$ do n. ${ }^{\circ}$ III, se o agente se apropriar, em beneficio proprio ou alheio, da guantia ilegalmente percebida.

Pr. 340 - 0 funcionario público encarregado da arrecadação, cobrança ou administração de quaesquer rendas ou dinheiros publicos ou da distribuição de qualquer imposto que direta ou indiretamente: 1) exigir dos contribuintes e deles receber o que souber não ser devido; 2) se apropriar do que assim indevidamente tiver recebido; 3) transigir contra o fisco, mediante vantagem ilícita; 4) usar na cobrança de impostos e direitos, embora legitimos, de meios mais gravosos do que os autorizados em lei, ou impuzer ao contribuinte vexações, injustas será 
punido: a) no caso do n. 1 com multa, e, se tiver recorrido á força armada em detenção por 3 meses no minimo; b) nos casos dos ns. 2 e 3 com prisão até 3 anos e multa; c) no caso do n. 4 com detenção por 3 meses no minimo, e, se tiver havido apropriação, com prisão até 4 anos e multa.

Cons. 219 - Julgar-se-á cometido este crime: $\S 10^{\circ}-$ Pelo empregado publico encarregado de arrecadação, cobrança ou administração de quaesquer rendas ou dinheiros públicos, ou da distribuição de algum imposto, quer direta ou indiretamente, exigir dos contribuintes, ou os obrigar a pagar o que souber não deverem, suspensão do emprego por 3 meses a 1 ano; no caso em que o empregado público se aproprie do que assim tiver exigido ou exija para esse fim -6 meses a 1 ano, multa. e perda do emprego. $\S 2 .^{\circ}$ - Pelo que, para cobrar impostos ou direitos legitimos, empregar volutariamente contra os contribuintes meios mais gravosos do que os prescritos nas leis ou os fizer sofrer injustas vexações - suspensão por 6 meses a 2 anos, além das mais em que incorrer pela vexação. Se, para cometer algum destes crimes, usar de força armada... mais a de prisão... por 3 meses a 1 ano. $\S 3 .^{\circ}-$ Pelo que, arrogando-se dolosamente, ou simulando atribuição para fazer qualquer áto do emprego, aceitar oferecimento ou receber rádiva, direta ou indiretamente para fazer ou deixar de fazer esse áto - 6 meses a 1 ano... 220: As pessoas particulares, encarregadas por arrecadamento, arrematação ou qualquer outro titulo de cobrar e administrar rendas ou direitos e que cometerem algum ou alguns dos crimes referidos nos arts. antecedentes incorrerão nas mesmas penas.

Art. 154 - Receber para si ou para outrem, diretamente ou por interposta pessôa, em dinheiro ou utilidade de outra especie, retribuição indébita, ou aceitar, direta ou indiretamente, promessa de tal retribuição, afim de praticar áto do oficio, conforme aos deveres funcionaes.

Pena - reclusão por 1 a 3 anos e multa correspondente ao triplo do valor prometido ou recebido, mas nunca inferior a $1: 000 \$ 000$

$\S$ unico — Se o áto já estiver práticado, quando solicitada ou aceita a retribuição.

Pena - detenção por 3 meses a 1 ano e multa igual ao triplo do valor prometido ou recebido, mas nunca inferior a $500 \$ 0000$.

Pr. 341 - 0 funcionario público que, para cumprir o seu dever, exigir direta ou indiretamente, gratificação, emolumento ou premios não determinados por lei, será punido com multa; e, se de fato tiver recebido - que indebitamente exigir, com detenção minima de 3 meses e com multa. 
Cons. 214 - Receber para si ou para outrem, diretamente ou por interposta pessoa, em dinheiro ou outra utilidade, retribuição que não seja devida; aceitar, direta ou indiretamente, promessa, dadiva ou recompensa para praticar ou deixar de praticar um ato do oficio ou cargo, embora de conformidade com a lei -6 meses a 1 ano e multa igual ao triplo da cousa ou utilidade recebida.

Art. 155 - Receber para si ou para outrem, diretamente ou por intermedio de outra pessôa, em dinheiro ou utilidade de outra especie, retribuição indébita, ou aceitar, direta ou indiretamente, promessa de tal retribuição, afim de retardar ou deixar de praticar áto do oficio, ou praticá-lo com infração de dever funcional.

Pena - reclusão por 2 a 5 anos e multa correspondente ao quintuplo do valor prometido ou recebido, mas nunca inferior a $2: 000 \$ 000$.

$\S 10^{\circ}$ - Se do áto resultar proveito ou dano para uma das partes em processo judicial ou administrativo.

Pena - a mesma, aumentada.

$\S 20^{\circ}$ - Se resultar condenação á reclusão.

Pena - reclusão por 6 a 20 anos e multa correspondente ao décuplo do valôr recebido ou prometido, mas nunca inferior a $5: 000 \$ 000$.

$\S 3 .^{0}$ - Se resultar condenação á morte.

Pena - reclusão por 20 a 30 anos e multa correspondente a vinte vezes o valor recebido ou prometido, mas nunca inferior a $10: 000 \$ 000$.

$\S 4 .^{\circ}$ - Se o áto já estiver praticado, omitido ou retardado, quando solicitada ou aceita a retribuição.

Pena - detenção ou reclusão por 1 a 3 anos e multa igual ao triplo do valor prometido ou recebido, mas nunca inferior a $1: 000 \$ 000$.

Pr. 342 - Aquele que, no exercicio de autoridade pública ou no desempenho de função pública, para praticar qualquer áto do oficio que importe na violação de seus deveres, tiver solicitado ou aceito retribuição ou obtido a promessa de retribuição, será punido com prisão até 3 anos e multa, ou com detenção por 3 a 9 meses e multa. A prisão será até 5 anos e a detenção por 6 meses no mínimo se o áto a que a retribuição visava se tiver efetuado. $\S$ un. Intencionalmente omitir ou 
retardar ato do oficio, tendo-se em vista retribuição ilegitima, equivale a praticá-lo.

Cons. 214 - Receber para si ou para outrem, diretamente ou por interposta pessoa, em dinheiro ou outra utilidade, retribuição que não seja devida; aceitar, direta ou indiretamente, promessas, dadiva ou recompensa, para praticar ou deixar de praticar um ato do oficio ou cargo embora de conformidade com a lei. 216: Nas mesmas penas (6 meses a 1 ano) incorrerá o juiz de direito, de fato ou árbitro que por peita ou suborno, dér sentença ainda que justa. § um. Se a sentença fôr criminal condenatoria, mas injusta, sofrerá o peitado ou subornado a mesma pena que tiver imposto ao que condenara, além da perda do emprego e multa.

Art. 156 - Praticar, omitir ou retardar áto do oficio, com infração de dever funcional, cedendo a influencia ou pedido de alguem.

Pena - detenção por 3 meses a 1 ano, ou multa de $500 \$ 000$ a 2:000\$000.

Pr. 338 - Se a nenhuma vantagem ilícita tiver visado o funcionario, mas somente pela influencia ou peditorio de alguem se tiver decidido, a pena será a de detenção até 3 meses ou a multa.

Cons. 215 - Deixar-se corromper por influencia, ou sugestão de alguem, para retardar, omitir, praticar ou deixar de praticar um áto contra os deveres do oficio no cargo, para prover ou propor para emprego publico alguem, ainda que tenha os requesitos legaes - 6 mêses a 1 ano e perda do emprego, com inhabilitação para outro.

Art. 157 - Recusar, omitir ou retardar indevidamente áto do oficio, ou praticá-lo contra literal disposição da lei.

Pena - detenção por 3 meses a 1 ano ou multa de $500 \$ 000$ a $2: 000 \$ 000$.

$\S 1 .^{\circ}$ - Recusar ou retardar, indebitamente, agente da força pública, o cumprimento de requisição que por autoridade competente lhe seja feita.

Pena - detenção por 6 meses a 2 anos ou multa de 1 a $3: 000 \$ 000$.

$\S 20^{\circ}$ - Acumular-se-ão e agravar-se-ão as penas cominadas neste dispositivo:

I - se do crime resultar grave prejuizo para o interessado ou para a administração pública. 


\section{II - se o crime fôr cometido por afeição, odio, contempla-} ção, ou interesse pessoal.

Pr. Omisso.

Cons. 207 - Cometerá crime de prevaricação o funcionário público que, por afeição, odio, contemplação ou para promover interesse pessoal, seu. 1) julgar ou proceder contra literal disposição da lei... 2) deixar de proceder e formar processo aos delinquentes nos casos determinados em lei, e dar-lhes a nota constitucional de culpa no praso de 24 horas; 3) recusar ou demorar a administração da justiça, ou as providencias do oficio requisitadas por autoridade competente ou determinadas por lei; 4) exceder os prazos estabelecidos em lei para o relatorio ou revisão do feito, ou para proferir sentença definitiva ou despacho... 5) julgar causas em que a lei o declare suspeito como juiz de direito, de fáto ou arbitro, ou em que as partes o hajam legitimamente recusado ou suspeitado; 6) ordenar a prisão de qualquer pessoa, sem ter para isso causa ou competencia legal, ou, tendo-a, conservar alguem incomunicavel por mais de $\mathbf{4 8}$ horas, ou retê-la em cárcere privado ou em casa não destinada a prisão; 7) demorar o processo de réo preso ou afiançado além dos prazos legais, ou faltar aos átos de seu livramento; 8) recusar ou retardar a concessão de uma ordem de habeascorpus, regularmente requerida; 9) fazer remessa do preso a outra autoridade; ocultá-lo ou transferí-lo da prisão em que estiver; não apresentá-lo no lugar e no tempo determinado na ordem de habeas-corpus; deixar de dar conta circunstanciada dos motivos da prisão, ou do não cumprimento da ordem iludindo por esses meios a concessão do habeascorpus; 10) tornar a prender, pela mesma causa o que tiver sido solto em provimento de habeas-corpus; 11) executar a prisão de alguem sem ordem legal escrita da autoridade legítima; ou receber sem essa formalidade, algum preso, salvo o caso de flagrante delito ou de impossibilidade absoluta da apresentação da ordem - 6 meses a 1 ano e multa de $200 \$ 000$ a $600 \$ 000$; 12) deixar o juiz de promover o processo pelo crime de prevaricação previsto no (cod. eleitoral) -6 meses a 1 ano e multa de $500 \$ 000$; 13) demorar a extração, expedição e entrega de titulos ou documentos, de modo a impedir que o cidadão vote, ou instrua recurso, interposto oportunamente; 14) deixar de preparar ou expedir nos prazos legaes os requerimentos dos cidadãos que pretenderem alistar-se eleitores; extraviar ou ocultar o titulo de eleitor ou documentos que lhe tenham sido entregues, relativos ao alistamento -6 meses a 1 ano e multa de 600 a 1:000\$000. $\S 10^{\circ}-$ Se a prevaricação consistir em impôr pena contra literal disposição da lei e o condenado a sofrer, impôr-se-á a mesma pena ao juiz, ou juizes, se a decisão fôr coletiva, além da perda do emprego. $\S 20^{\circ}$ - No caso, porém, que o condenado não tenha sofrido a pena, impôr-se-á ao juiz, ou juizes, 
a que estiver designada para a tentativa do crime sobre que tiver recaido a condenação. 210: Se qualquer dos crimes mencionados nos arts. 207 e 208. f fôr cometido por frouxidão, indolencia, negligencia o uomissão, constituirá falta de exação no cumprimento do dever e será punido com as penas de suspensão por 6 meses a 1 ano e multa de $100 \$$ a $500 \$ 000$. 212: A execução de ordem ou requesição exigida por autoridade pública só pode ser demorada pelo executor nos seguintes casos: a) quando houver motivo para prudentemente se duvidar de sua autenticidade; b) quando parecer evidente que fôra obtida ob e subrepticiamente, ou contra a lei; c) quando da execução se devam prudentemente receiar graves males que o superior ou requesitante não tivesse podio prever. Ainda que neste caso possa o executor da ordem, ou requesição, suspender a sua execução para representar, todavia não será isento de pena, se não demonstrar claramente a relevancia dos motivos em que se fundara.

Art. 158 - Ter ou tomar interesse privado, diretamente, ou por interposta pessôa, ou mediante simulação, em áto da administração pública, junto á qual funcionar.

Pena - detenção por 6 meses a 3 anos e multa de 1 a $10: 000 \$ 000$.

$\S$ unico - Nas mesmas penas incorrerão o juiz, o síndico, o liquidatario, o tutor, o curador e os serventuarios e auxiliares da justiça, com referencia aos processos em que funcionarem.

Pr. 339 - 0 funcionario público que direta ou indiretamente se reservar qualquer interesse material em negocios da sua repartição, ou em processos que por ela corram, será punido com detenção por 1 a 6 meses e com multa.

Cons. 232 - Haver para si, direta ou indiretamente, ou por algum ato simulado no todo ou em parte, propriedade ou efeito, em cuja propriedade, administração ou guarda deva intervir em razão do oficio; entrar em alguma especulação de lucro ou interesse relativamente á dita propriedade ou efeito -1 a 6 meses... perda... multa de 5 a $20 \%$.

Art. 159 - Sacrificar interesse público, de que lhe incumba a defesa, para haver,em beneficio próprio ou de terceiro, vantagem ilícita.

Pena - reclusão por 1 a 5 anos e multa de 1 a 20:000\$000.

Pr. 338 - 0 funcionário público que, com o fim de obter vantagem ilicita, para si ou para outrem, transigir em negocio jurídico ou 
administrativo, em prejuizo do interesse público, que lhe cumpria resguardar ou defender, será punido com detenção por 6 meses, no minimo, ou com prisão até 2 anos e, mais, em qualquer hipótese, a multa.

Cons. Omissa.

Art. 160 - Revelar ou aproveitar, em beneficio alheio ou próprio, esclarecimento destinado a ficar secreto, com referencia a invenção científica ou aplicação industrial, de que o funcionario tenha conhecimento em razão do cargo.

Pena - detenção por 3 anos e multa de 1 a $15: 000 \$ 000$.

$\S$ unico - Aumentar-se-ão as penas, se a revelação tiver sido feita a estrangeiro, e dobrar-se-ão, se a revelação feita a estrangeiro fôr de segredo que interesse á defesa nacional. Em qualquer destes casos a pena detentiva será a de reclusão.

Pro. Omisso.

Cons. Omissa.

Art. 161 - Revelar fato, de que tenha ciencia em razão do cargo e que deva permanecer em segredo, ou facilitar de qualquer modo a sua revelação.

Pena - detenção por 3 meses a 1 ano ou a multa de 1 a 10:000\$000.

$\S 1 .^{\circ}$ - Não haverá logar a aplicação da pena, quando a revelação fôr necessaria á salvaguarda de relevante interesse público e autorizada préviamente por superior hierárquico. litação.

$\S 2 .^{\circ}$ - Diminuir-se-á a pena, quando fôr culposa a faci-

$\S 3 .^{\circ}$-- Aumentar-se-ão e cumular-se-ão as penas, quando o funcionario devassar indebitamente ou facilitar a outrem o devassamento de proposta de concorrencia pública.

Pr. 348 - 0 funcionario público que, para conhecer-lhe o conteúdo, abrir antes do tempo, proposta de concorrencia púbilica, ou por quálquer outro modo lhe devassar o segredo ou proporcionar a terceiro o ensejo de devassá-lo, será punido com detenção por 3 a 9 meses ou com prisão até 2 anos, $\theta$ em ambos os casos com culta. 347: 0 funcionario público que revelar o conteŕdo de documento reservado ou secreto, 
ou da correspondencia reservada ou secreta, e que pertença á sua repartição, ou por ela transitar, será punido com detenção até 6 meses ou com multa.

Cons.: Omisse.

Art. 162 - Abusar do cargo, praticando, com o intuito de causar dano a alguem ou de obter vantagem em proveito próprio ou de terceiro, áto contrário á lei, que não esteja previsto como crime por disposição especial.

Pena - detenção por 6 meses a 2 anos e multa de $500 \$$ a $10: 000 \$ 000$.

Pro. Omisso.

Cons. 207: Cometerá crime de prevaricação o empregado público que julgar ou proceder contra literal disposição de lei.

Art. 163 - Menoscabar, no exercicio de função pública, as instituições vigentes, ou os dispositivos legaes, ou as autoridades constituidas, ou fazer apologia de átos que importem em tal menoscabo.

Pena - detenção por 3 meses a 1 ano e multa de 500\$ a 1:000\$000, se o fato não estiver previsto como crime em disposição especial.

$\S$ unico - O presente dispositivo aplicar-se-á ao ministro de culto religioso que nele incorrer, por áto praticado no exercicio público de seu ministerio.

Pro. Omisso.

Cons. Omissa.

Art. 164 - Punir-se-á com multa de 200\$ a 2:000\$ o funcionario que:

I - entrar no exercicio de função pública, antes de satisfeitas as exigencias legais;

II - continuar a exercê-la, sem a devida autorização, depois de saber oficialmente que está exonerado, removido, substituido ou suspenso;

III - abandonar o exercicio fóra dos casos permitidos em lei ou conservar-se fóra dêle, mais de 60 dias depois de terminada a licença ou comissão em que estiver. 
IV - propuzer ou nomear para cargo público pessôa que não tiver os requesitos legaes;

V - exceder os limites da competencia própria;

V1 - devido a indulgencia ou negligencia, não responsabilizar subordinado, por infração cometida no exercicio do cargo, ou quando lhe falte competencia para isso, não levar o fato ao conhecimento da autoridade competente;

VII - maltratar, com atos ou palavras, funcionario subalterno ou pessôa com quem se entender em razão do oficio; ou cometer outra violencia no exercicio da função ou a pretexto de exercê-la; ficando sujeito não só á pena cominada neste artigo, como á cominada em outro dispositivo penal, em que incorrer;

VIII - constituir-se devedor ou afiançado de subalterno, ou contrair com êle obrigação pecuniaria;

IX - solicitar mulher pessoalmente interessada ou cujo marido, irmão, ascendente ou descendente tenha interesse em litigio ou negocio em que o agente deva intervir em razão do oficio.

Pr. 336 - A autoridade ou funcionário público que, para favorecer ou prejudicar a alguem, se arrogar competencia ilegítima, da própria competencia abusar, ou exercê-la com preterição das formalidades legaes, será punido com detenção até 3 meses ou com multa. 337: $O$ funcionario público que, por indulgencia ou neglicencia, não responsabilizar os subordinados, ou não diligenciar por que se lhes apure a responsabilidade pelos abusos e omissões que cometerem, no exercicio de suas funções, será punido com multa. $33 \S$ un.: Na aplicação deste art. entender-se-á que tambem ocupa função ou poder quem lhes antecipar o exercicio, sem preencher as formalidades legaes da posse, ou nele continuar, embora oficialmente saiba já ter sido suspenso ou demitido, ou se recusar a passa-lo ao substituto legitimo, quando removido; nestes casos porém, aplicar-se-á a multa e, acessoriamente, a interdição relativa.

Cons. 207 - Cometerá crime de prevaricação o funcionário público que... a) dissimular ou tolerar os crimes e defeitos oficiais de seus subalternos ou subordinados, deixando de proceder contra êles, ou de informar á autoridade superior respetiva, quando lhe falte competencia para tornar efetiva a responsabilidade em que houverem incorrido. 211: Serão considerados em falta de exação no cumprimento do dever... o que abandonar o exercicio do cargo fóra dos casos em que a lei expressamente o permite ou conservar-se fóra dele mais de 60 dias depois de terminada a licença ou comissão em que estiver. 225: Entrar em exercicio ou emprego sem ter satisfeito préviamente ás exigencias da lei 
para a investidura no mesmo - suspensão... e multa... 226: Exceder os limites das funções do emprego ou comissão, depois de saber oficialmente que está suspenso, demitido, removido ou substituido legalmente, exceto nos casos em que fôr autorizado competentemente a continuar - 1 mês a 1 ano e multa ... 227: Continuar a exercer as funções próprias do emprego ou comissão, depois de saber oficialmente que está suspenso, demitdo, removido ou substituido legalmente, exceto nos casos em que fôr autorizado competentemente a continuar - 1 mês a 1 ano e multa ... 230: Exceder a prudente faculdade de repreender, corrigir ou castigar, ofendendo, ultrajando ou maltratando, por obras, palavra ou escrito, algum subalterno, dependente ou qualquer outra pessoa com quem tratar em razão do oficio - suspensão, além das mais ... 231: Cometer qualquer violencia no exercicio das funções ou emprego ou a pretexto de exercê-las — perda ... suspensão ... além das mais ... 234: Constituir-se devedor de algum subalterno, dá-lo por seu fiador, ou contrair com ele obrigação pecuniaria - suspensão ... e multa ... 235: Solicitar alguma mulher que tenha litigio ou pretensão dependente de decisão, ou informação, em que deva intervir em razão do cargo suspensão ... além das mais ... Se o que cometer este crime fôr juiz - 1 mês a 1 ano, além das mais ... 236: Se o crime declarado no art. antecedente fôr cometido por carcereiro, guarda ou empregado da cadeia, casa de reclusão ou estabelecimento semelhante, contra mulher que esteja presa ou depositada, debaixo de sua custodia ou vigilancia, ou contra mulher, filha ou irmã, tutelada ou curatelada de pessoa que se achar nessas circunstancias -1 mês a 1 ano $\ldots$ perda ... além das outras mais ...

\section{Capitulo II}

\section{Dos crimes praticados por particulares contra a administração pública em geral}

Art. 165 - Fingir-se autoridade ou funcionario público.

Pena - detenção por 1 a 3 meses ou multa de $200 \$$ a $1: 000 \$ 000$.

$\S 10^{\circ}$ - Usurpar o exercicio de função pública ou atribuição inherente a cargo público.

Pena - detenção por 3 meses a 2 anos e multa de $500 \$ 000$ a $2: 000 \$ 000$.

$\S 20^{\circ}-$ Se, mediante, fingimento ou a usurpação, o agente obtiver dinheiro ou vantagem ilícita.

Pena - reclusão por 2 a 5 anos e multa de 1:000\$000 a $10: 000 \$ 000$. 
Pr. 333 - Aquele que visando a fins ilícitos, usurpar o exercicio de funçção pública, civil ou militar, será punido com prisão por 2 a 6 meses, ou com prisão por 6 meses a 2 anos. 481 (traje indevido!): Será punido com detenção até 1 mês ou com multa aquele que ... fingir-se de empregado público.

Cons. 381 - Fingir-se empregado público - 1 a 3 meses. Se por esse meio conseguir de outrem dinheiro ou utilidade - as do art. 335 (1 a 4 anos) 224: Arrogar-se e efetivamente exercer sem direito emprego ou função pública, civil ou militar -6 meses a 2 anos e multa igual ao dobro dos vencimentos que tiver recebido.

Art. 166 - Punir-se-á com detenção por 3 meses a 2 anos aquele que, mediante ameaça ou violencia:

I - impedir que autoridade ou funcionario público assuma o exercicio do cargo, ou constrangê-lo a abandonar o exercicio de suas funções ;

II - obrigar autoridade ou funcionario público a praticar ou deixar de praticar ato do oficio, ou a praticá-lo de certa maneira ou em determinado sentido.

§ unico - A pena será de detenção por 6 meses a 3 anos, se o crime fôr cometido a mão armada ou por duas ou mais pessoas.

Pr. 329 - Com detenção por 3 a 9 meses, ou com prisão até 18 punir-se-á aquele que usando de violencia ou de ameaças: 1) impedir que o funcionario público munido de titulo legítimo tome posse do cargo para o qual tiver sido nomeado; 2) constranger funcionario público a abandonar o cargo, a praticar ou deixar de praticar qualquer ato do oficio ou a praticá-lo no sentido ou pela maneira que lhe impuzer.

Lei n. 38: 5 - Impedir que funcionario público tome posse do cargo para o qual tiver sido nomeado; usar de ameaça ou violencia para forçá-lo a praticar ou deixar de praticar qualquer ato do oficio ou obrigar a exercê-lo em determinado sentido. (3 a 9 meses).

Art. 167 - Opôr-se, mediante ameaça ou violencia, á execução de ordem legal emanada de autoridade ou funcionario público, quer a resistencia se faça diretamente contra um deles, quer contra quem lhe prestar assistencia.

Pena - detenção por 6 meses a 2 anos, quando se execute a ordem, sem que o executor sofra lesão, da parte do resistente; e reclusão por 1 a 4 anos, se, devido á resistencia, não se puder 
executar a ordem, ou esta se execute, sofrendo, porém, lesão o executor, da parte do resistente.

Pr. 327 - Será punido com prisão até 2 anos aquele que usando de violencia ou de ameaças: 1) se opuser á execução de atos legitimos ou ao cumprimento de ordem legal de autoridade competente; 2) impedir, ou tentar impedir, a cobrança de taxa ou imposto legalmente exigiveis.

Cons. 124 - Opôr-se alguem, com violencia ou ameaças, á execução de ordens legaes emanadas de autoridade competente, quer a oposição seja feita diretamente contra a autoridade, quer contra seus agentes ou subalternos. $\S 1 .^{\circ} \mathrm{Se}$, em virtude da oposição, a diligencia deixar de efetuar-se, ou efetuar-se, sofrendo o executor da parte dos resistentes qualquer lesão corporal -1 a 3 anos. $\$ 2 .^{\circ}$ Se a diligencia efetuar-se, não obstante a oposição sem que o executor sofra da parte dos resistentes, alguma lesão corporal - 6 meses a 1 ano. 125: 0 mal causado pelo executor na repulsa ou força empregada pelos resistentes não lhe será imputado, salvo excesso de justa defesa.

Art. 168 - Desobedecer a ordem legal de autoridade ou de funcionario público, em ato ou exercicio de suas funções.

Pena - detenção por 15 dias a 6 meses ou multa de $100 \$ 000$ a 2:000\$000, quando outra não fôr especialmente cominada.

Pr. 328 - Será punido com detenção até 3 meses, dobrados na reincidencia, aquele que: 1) desobedecer á autoridade em ato de suas funções ou não cumprix as suas ordens legaes; 2) infringir as proíbições de edital expedido por autoridade competente ...

Cons. 135 - Desobedecer á autoridade pública em ato ou exercicio de suas funções, deixar de cumprir suas ordens legaes, transgredir uma ordem ou provimento legal, emanado de autoridade competente - 1 a 3 meses. $\S$ un. Serão compreendidos nesta disposição aqueles que infringirem preceitos proíbitivos de editaes das autoridades dos quaes tiverem conhecimento.

Art. 169 - Desacatar autoridade ou funcionario público, por motivo ou ao tempo do exercicio de suas funções, provocando-o, ameaçando-o, ou faltando-lhe com a devida consideração.

Pena - detenção por 2 meses a 1 ano, ou multa de $500 \$ 000$ a $5: 000 \$ 000$. 
§ $10^{\circ}$ - Se o ofendido fôr o Presidente da Republica, membro do poder legislativo, governador ou interventor federal em Estado ou territorio, ministro do governo da União ou secretario de governo estadoal ou magistrado.

Pena - detenção ou reclusão por 1 a 3 anos.

$\S 20^{\circ}$ - Aumentar-se-á, em qualquer hipótese, a pena, se o desacato fôr praticado em ato ou sessão pública ou dentro de repartição pública.

Pr. 329 - Com detenção por 9 meses, ou com prisão até 18 , punir-se-á aquele que, usando de violencia ou de ameaças ... a) agredir ou por palavras ou gestos ofender, sem ter sido provocado, qualquer funcionario público em sua repartição ou em ato de oficio. 373: Aquele que por motivo politico ou sectario .. em publico diretamente ultrajar o Presidente da Republica - 1 a 4 anos.

Cons. 134 - Desacatar qualquer autoridade ou funcionario público, em exercicio de suas funções, ofendendo-o diretamente por palavras ou atos, ou faltando á consideração devida e á obediencia hierárquica 2 a 4 meses, além das mais em que incorrer. § un. Se o desacato fôr praticado em sessão pública de camaras legislativas ou administrativas, ou tribunaes, de qualquer corporação docente ou dentro de repartição pública - aumento da terça parte.

Art. 170 - Auferir retribuição ou vantagem ilícita, em beneficio proprio ou alheio, ou obter promessa, para si ou para outrem, de retribuição ou vantagem dessa natureza, a pretexto de exercer influencia junto a uma autoridade ou funcionario público, em ato do oficio.

Pena - reclusão por 1 a 5 anos e multa de 3 a 20:000\$000.

$\S$ unico - Aumentar-se-á a pena se o agente declarar ou der a entender que da vantagem auferida ou prometida participará a autoridade ou funcionario público.

Pr. Omisso.

Cons. Omissa.

Art. 171 - Dar, oferecer ou prometer retribuição ou vantagem iícita a autoridade ou funcionario público, para determiná-lo a praticar, ou não praticar, ou retardar ato do oficio, ainda que sem violação de dever funcional. 
Pena - reclusão por 1 a 5 anos e multa de 1 a 20:000\$000.

Pr. 335 - Aquele que afrontar o representante de um dos poderes do Estado, a autoridade civil ou militar ou o funcionario público, oferecendo-lhe, dando, ou prometendo retribuição pecuniaria ou qualquer vantagem ilícita, para determiná-los a fazer, ou deixar de fazer alguma cousa, mesmo quando, assim procedendo não violarem os deveres da função ou cargo, será punido com detenção por 6 meses no minimo e com multa.

Cons. 217. -0 que dér ou prometer peita ou suborno será punido com as mesmas penas impostas ao peitado ou subornado.

Art. 172 - Causar, fóra dos casos previstos em outras disposições legaes, a interrupção ou a irregularidade de serviço público ou de necessidade pública.

Pena - reclusão por 1 a 4 anos, para os cabeças, promotores e organizadores; e detenção por 3 meses a 1 ano, ou multa de 1 a $5: 000 \$ 000$, ou ambas cumulativamente para os outros participes.

Pr. 332 - Aquele que indebitamente intervier, para malográ-lo, em ato oficial ou de serviço que o funcionario deva praticar contra terceiro será punido com detenção até 6 meses ou com multa.

Cons. Omissa.

Art. 173 - Importar ou exportar mercadoria ou genero proibido; ou iludir no todo ou em parte o pagamento dos direitos ou impostos relativos á entrada, saida e consumo de mercadorias.

Pena - reclusão por 1 a 4 anos, sem prejuizo das penalidades fiscaes.

Art. 174 - Impedir ou perturbar concorrencia pública ou venda em hasta pública, promovidas pela administração federal, estadual ou municipal, afastando ou procurando afastar licitante mediante violencia, ameaça, promessa ou qualquer meio fraudulento.

Pena - detenção por 6 meses a 2 anos ou multa de 1 a $10: 000 \$ 000$.

$\S 10^{\circ}$ - Punir-se-á com detenção por 3 meses a 1 ano ou multa de 500\$000 a 5:000\$000 aquele que, mediante paga ou promessa de recompensa, se abstiver de licitar em concorrencia ou hasta pública promovidas pela administração federal, estadual ou municipai. 
$\S 20^{\circ}$ - Diminuir-se-ão as penas cominadas neste dispositivo, quando se tratar de praça judicial, a requerimento de particular. Neste caso sómente se procederá mediante queixa.

Pr. Omisso.

Cons. Omissa.

Art. 175 - Punir-se-á com detenção por 1 mês a 1 ano ou com multa de 500\$000 a 3:000\$000 aquele que:

I - rasgar, ou de qualquer fórma inutilizar ou conspurcar edital afixado por ordem de autoridade ou funcionario público;

II - vender, distribuir ou afixar em logar público ou aberto ao público escrito ou desenho proíbido;

III - violar ou de qualquer fórma inutilizar selo ou sinal aposto por determinação legal ou ordem de autoridade ou funcionario público para identificar objeto ou cerrá-lo.

$\S$ unico - Aumentar-se-á a pena se o crime fôr cometido, com abuso do cargo, por funcionario público.

Pr. 228 - Será punido com detenção de 3 meses, dobrada na reincidencia, aquele que ... o arrancar (edital), riscar, apagar, ou inutilizar, quando afixado em logar público. 334: Aquele que violar, furtar, destruir, rasgar ou inutilizar o selo público ou as marcas, distintivo, timbres de carimbos oficiaes que a autoridade apuser a qualquer objeto para encerrá-lo ou identificá-lo, ou que de outro modo privar de feito aqueles sinaes, será punido çom detenção até 6 meses ou com multa.

Art. 176 - Subtrair, ocultar, danificar ou destruir documento, registro, livro ou qualquer objeto corfiado oficialmente á custódia de funcionario público ou de particular.

Pena - reclusão por 1 a 4 anos.

$\S 10^{\circ}$ - Aumentar-se-á a pena, se o agente cometer o crime para haver, em proveito proprio ou de terceiro, vantagem ilícita.

$\S 2 .^{\circ}$ - Diminuir-se-á a pena se, antes do julgamento, se der a restituição do objeto subtraido ou ocultado. 
Pr. 330 - Será punido com detenção por 1 a 3 meses ou com prisão por 3 meses a 1 ano aquele que, das mãos da autoridade ou funcionario público, ou de seu poder ou guarda: 1) arrebatar ou subtrair objetos apreendidos, confiscados ou depositados; 2) arrebatar ou tirar algum individuo legalmente preso ou detido. $\S$ un. $\mathrm{Na}$ aplicação deste art. considerar-se-á como autoridade ou funcionario público: 1) o particular, quando, por uma ou por outro requerido, lhes prestar auxilio ou quando prender em flagrante o criminoso; 2) os inferiores ou agentes da força pública, quando cumprirem ordens; 3) o depositario legal ou judicial, quanto ao deposito. 331: Será punido com prisão por 6 meses a 2 anos aquele que, da repartição pública ou da séde de algum serviço público: 1) tirar documento ou qualquer outro objeto que se destine a provar, ou seja apto a provar qualquer fato de consequencia jurídica; 2) tirar livros de ... autos ou processos; 3) suprimir ou danificar algum documento, livro de serviço, auto ou processo, de modo a torná-lo imprestavel como elemento de prova. A prisão será por ... 1 a 4 anos, quando, para perpetrar o crime, se tiver usado de violencia ou tiver sido ele perpetrado publicamente, com arruido ou ameaças. $\S$ un. A restituição, antes da sentença, do objeto tirado, sem estrago ou dano substancial ou diminuição de seu valor probante, e sem que tenha obtido o criminoso o fim a que visava, produzirá os seguintes efeitos: 1) aplicação da detenção até 3 meses ou da multa, em vez da pena de prisão, primeiramente cominada neste artigo; 2) redução ao minimo de 4 meses e au maximo de 1 ano, da pena de prisão cominada em $2 .^{\circ}$ logar.

Cons. 326 - Destruir ou inutilizar livros de notas, registros, assentamentos, atos e termos; autos e atos originaes de autoridade pública; livros comerciaes e em geral todo e qualquer papel, titulo ou documento que sirva para fundamentar ou provar direitos, sem haver lucro ou vantagem para si ou para outrem - 2 meses a 1 ano e multa de $\quad 5$ a $20 \%$. $\S$ un. Se o crime fôr cometido, auferindo o deliquente proveito para si ou para outrem -1 a 4 anos e multa de 5 a $20 \%$.

\section{Capitulo III}

\section{Dos crimes contra a administração da Justiça}

Art. 177 - Fazer justiça pelas proprias mãos, dispensando, fóra dos casos em que a lei o permite, a intervenção da autoridade competente, para satisfazer pretenção, embora legítima.

Pena - multa de $200 \$ 000$ a $1: 000 \$ 000$. 
$\S 10^{\circ}$ - Se o agente cometer o crime com violencia á cousa, danificando-a, transformando-a ou mudando-lhe a destinação.

Pena - multa de 300\$000 a 3:000\$000.

$\S 2 .^{\circ}$ - Se o crime for cometido com ameaça ou violencia á pessoa.

Pena - detenção por 1 a 6 meses ou multa de $500 \$ 000$ a $5: 000 \$ 000$, ou ambas cumulativamente, além daquelas em que incorrer pela violencia.

$\S 3 .^{\circ}$ - Só mediante queixa se procederá nos casos da cabeça do artigo e do $\S 1 .^{\circ}$.

Pr. 357 - Aquele que para fazer vingar direito, embora legítimo, ou liquidar alguma relação juridica, recorrer ás proprias forças dispensando a intervenção da justiça, fóra dos casos em que a lei o permite, será punido com detenção até 6 meses e com multa.

Cons. Omissa.

Art. 178 - Punir-se-á com multa de 200\$ a 2:000\$000 aquele que omitir ou retardar a denuncia á autoridade competente.

I - de crime de ação pública, de que no exercicio de função pública tiver conhecimento;

II — de crime de ação pública, de que tiver conhecimento no exercicio da medicina ou de outra profissão sanitaria, uma vez que a denuncia não exponha o cliente a procedimento criminal;

III - de crime contra a personalidade do Estado punido com reclusão por 5 anos, no minimo.

Pr. Omisso.

Cons. Omissa.

Art. 179 - Dar causa á instauração de procedimento criminal contra alguem, imputando-lhe falsamente, em queixa ou denuncia, embora anônima ou sob nome suposto, a prática de crime.

Pena - reclusão por 1 a 5 anos e multa de 1 a 10:000\$000. 
$\S 10^{\circ}$ - A reclusão será por 1 a 15 anos e a multa de 3 a $30: 000 \$ 000$, se do fato resultar a condenação de inocente á reclusão por tempo superior a 5 anos.

$\S 2 .^{\circ}$ - Diminuir-se-á a pena, convertendo-se a reclusão em detenção, quando o agente se retratar antes do julgamento da vítima da imputação falsa.

Pr. 364 - Será punido com prisão até 3 anos aquele que sabendo ser alguem inocente, ou de sua culpabilidade não tendo veementes indicios: 1) imputar-lhe perante a autoridade a pratica de crime; 2) maliciosamente fizer que contra ele se abra inquerito policial. Aplicar-se-á até 3 meses e a multa, quando a imputação falsa se referir a contraveução. $\S$ un. A prisão será por 2 a 6 anos, quando a falsidade da imputação só se reconhecer em juizo, depois de condenada a vítima a pena privativa da liberdade.

Cons. 264 - Dar queixa ou denúncia contra alguem, imputandolhe falsa e dolosamente fátos que, se fossem verdadeiros, constituiriam crime e sujeitariam seu autor a ação criminal - a do crime imputado.

Art. 180 - Acusar-se perante a autoridade, oralmente ou por escrito, embora anônimo ou sob falso nome, de crime inexistente ou praticado por outrem.

Pena - detenção por 3 meses a 2 anos, ou multa de 1:000\$000 a 5:000\$000, ou ambas cumulativamente.

Pr. Omisso.

Cons. Omissa.

Art. 181 - Afirmar falsidade, ou negar ou calar a verdade, em testemunho, laudo ou tradução, feitos, qualquer que seja a fase do processo, perante a autoridade que o presidir.

$\S 10^{\circ}$ - Em se tratando de materia civel.

Pena - detenção por 3 meses a 1 ano e multa de 1 a $3: 000 \$ 000$.

$\S 20^{\circ}-$ Em se tratando de materia criminal, e sendo o crime cometido para beneficiar o réo.

Pena - detenção por 6 meses a 2 anos e multa de 2 a $10: 000 \$ 000$.

$\S 3 .^{\circ}$ - Em se tratando de materia penal, e sendo o crime cometido para prejudicar o réo. 
Pena - reclusão por 1 a 4 anos e multa de 5 a $15: 000 \$ 000$.

$\S 4 .^{\circ}$ - Aumentar-se-á a pena, se o crime fôr cometido mediante paga ou promessa de recompensa. Quem as fizer incorrerá:

I - na mesma pena que o agente, se o crime fôr cometido;

II - na mesma pena em que, se o crime fosse cometido, incorreria o agente, diminuida de um a dois terços, quando a oferta ou promessa não fôr aceita pela testemunha, intérprete ou perito, ou quando, embora aceita a promessa ou oferta, não se praticar a falsidade.

§ 5. - Não haverá logar a aplicação das penas estabelecidas neste dispositivo á testemunha, intérprete ou perito:

I - que se retratar, manifestando a verdade, antes de proferida a sentença definitiva, embora não irretratavel;

II - que estiver legalmente impedido de funcionar, como tal, no processo.

Pr. 365 - Aquele que em juizo, como perito, arbitrador, tradutor ou intérprete, cientemente apresentar laudos, pericia ou relatorios falsos, fizer tradução ou der interpretação falsa, será punido com prisão por 6 meses a 2 anos ou com detenção por 3 meses no minimo. Aplicar-se-á somente a multa, quando a falsidade não influir sobre a decisão da causa. § un. Aquele que subornar alguma das pessoas indicadas neste art. para cometer quaesquer dos crimes nele previstos, será punido com as mesmas penas de subornado. 336: Aquele que com o fim de embair a justiça, ou prejudicar alguem, der em juizo depoimento falso será punido com detenção de 6 meses ou com prisão por 6 a 12 meses. A retratação judicial da falsidade antes da sentença de primeira instancia exclue a pena. $0 \S$ un. do art. antecedente é aplicavel. 367: Na aplicação dos arts. 365 - 366 entender-se-seque a expressão "em juizo" tambem se refere á jurisdição administrativa, ao juizo arbitral, ás concessões internacionaes de arbitragem ou de inquerito, e ás parlamentares, desde que, no que concerne á testemunha, tenham elas competencia para lhe tomar o depoimento sob compromisso.

Cons. 261 - Asseverar em juizo como testemunha, sob compromisso ou afirmação, qualquer que seja o estado da causa e a natureza do processo, uma falsidade; ou negar a verdade, no todo ou em parte,, sobre circumstancias essenciaes do fato, a respeito do qual depuser. $\S 10^{\circ}$ Se 
a causa em que prestar o depoimento fôr civel -3 meses a 1 ano. § 2. Se a causa fôr criminal e o depoimento para absolvição do acusado - 6 meses a 2 anos. $\S 3 .^{\circ}$ Se para condenação -1 a 6 anos. 262: Todo aquele que, intervindo em causa civel ou criminal, no caráter de perito, intérprete ou arbitrador, fizer ou escrever declarações ou afirmações falsas, será punido com as mesmas penas, guardadas as distinções do art. anterior. $\S$ un. A pena será aumentada da terça parte, se o acusado deixar-se peitar, recebendo dinheiro, Iucro ou utilidade, para prestar depoimento falso, ou fizer declarações falsas, verbaes ou por escrito. Na mesma pena incorrerá o peitante. 263: Não terá logar a imposição da pena se a pessoa que prestar depoimento falso ou fizer declarações falsas em juizo, verbaes ou escritas, retratar-se antes de ser proferida sentença na causa.

Art. 182 - Usar de violencia ou ameaça para exercer influencia sobre depoimento de testemunha ou pronunciamento de juiz, jurado, intérprete ou perito.

Pena - reclusão por 1 a 4 anos e multa de 1 a 5:000\$000, além das outras em que incorrer pela violencia.

Pr. 353 - Aquele que, usando de violencia ou de ameaças, impedir ou tentar impedir que ... livremente exerça qualquer juiz as suas funções, será punido com prisão até 4 anos.

Cons. 113 - Usar de violencia ou ameaças, para constranger qualquer juiz, ou jurado, a proferir ou deixar de proferir, sentença, despacho ou voto; a fazer ou deixar de fazer algum ato oficial.

Art. 183 - Abster-se de denunciar imediatamente a quem de direito fato comprobatorio da inocencia de alguem, que esteja sendo processado criminalmente ou já tenha sido injustamente condenado.

Pena — detenção por 3 a 18 meses ou multa de 1 a 5:000\$000 ou ambas cumulativamente.

$\S$ unico - Aumentar-se-ão e cumular-se-ão as penas, se o crime fôr cometido por quem tenha contribuido, de boa fé, como querelante, denunciante, testemunha, intérprete, perito ou autoridade policial ou judicial, para a instauração do procedimento criminal ou para a condenação do réo.

Pr. Omisso.

Cons. Omissa. 
Art. 184 - Inovar artificiosamente, no curso de processo civel ou administrativo, estado de logar, cousa ou pessoa, para induzir em erro juiz ou perito, por ocasião de inspeção, exame pericial ou diligencia análoga.

Pena - detenção por 3 meses a 2 anos, ou multá de 1 a $10: 000 \$ 000$, ou ambas cumulativamente.

$\S$ unico - Aplicar-se-á este dispositivo, quando o ato fôr praticado no curso de processo penal ou anteriormente a ele; salvo, neste ultimo caso, se o crime não admitir ação pública e não fôr apresentada queixa ou representação.

Cons. Omissa.

Pr. Omisso.

Art. 185 - Recusar-se, sem justa causa, a prestar declarações ou a depôr como testemunha, ou a desempenhar as funções de jurado, defensor ou promotor ad hoc, tradutor, intérprete, perito ou depositario, quando convocado por autoridade competente.

Pena - multa de 100\$000 a 2:000\$000, podendo, outrossim o agente ser conduzido, debaixo de vara, quando se tratar de prestar declarações ou depoimento.

Pr. 480 - Poderão ser conduzidos debaixo de vara e serão punidos com multa: 1) a testemunha que, com falsos motivos, deixar de comparecer em juizo; 2) o jurado que, sem justa causa, faltar ao serviço do júri; 3) o auxiliar da justiça que, sem justa causa, se recusar a servi-la; 4) o parente, o cônjuge, ascendente, tutor ou curador, que, sem justa causa, não se apresentar ao juiz, quando convocado para dizer sobre negocio em que seja interessado incapaz, menor ou pessoa que deva ser internada.

Cons. Omissa.

Art. 186 - Punir-se-á com detenção por 6 meses a 3 anos ou multa de 2:000\$000 a 15:000\$000, ou ambas cumulativamente, o advogado ou procurador judicial:

I - que, conluiado, ou não, com a parte contraria, prejudicar intencionalmente a causa confiada ao seu patrocinio; 
II - que, diretamente ou por interposta pessoa, defender, ou representar, simultanea ou sucessivamente, partes contrarias na mesma questão;

III - que danificar ou não restituir autos, documentos ou objetos de valor probatorio que lhe tenham vindo ao poder, em razão do oficio.

$\S$ unico - $\mathrm{O}$ advogado ou procurador judicial que, a pretexto de obter o favor de juiz, jurado, órgão do Ministerio Público, testemunha, perito, intérprete ou qualquer autoridade ou funcionario, solicitar ou conseguir do cliente entrega ou promessa de dinheiro ou de vantagem ilícita, será punido com reclusão por 1 a 5 anos e multa de 5 a $20: 000 \$ 000$.

\section{Pr. Omisso.}

Cons. 209 - Ficarão compreendidos na disposição do art. precedente e serão julgados pela mesma fórma de processo que os funcionarios públicos o advogado ou procurador judicial: 1) que conluiar-se com a parte adversa e por qualquer meio doloso prejudicar a causa confiada ao seu patrocinio; 2) que ao mesmo tempo advogar ou procurar cientemente por ambas as partes; 3) que solicitar do cliente dinheiro ou valores, a pretexto de procurar favor de testemunha, peritos, intérpretes, juiz, jurado ou qualquer autoridade; 4) que subtrair ou extraviar dolosamente documentos de qualquer especie que lhe tenham sido confiados e deixar de restituir autos que houver recebido com vista ou em confiança - privação por 2 a, 4 anos multa de $20 \$$ a $500 \$ 000$, além das mais em que incorrerem pelo mal que causarem.

Art. 187 - Auxiliar alguem a subtrair-se á ação da autoridade pública, por motivo de crime, de que o agente não tenha participado; e para o qual se comine pena de morte ou de reclusão.

Pena - detenção ou reclusão por 1 a 4 anos.

$\S 10^{\circ}$ - Se o crime, que provocar a ação da autoridade, fôr punido com detenção ou multa.

Pena - multa de $200 \$ 000$ a $5: 000 \$ 000$.

§ $2 .^{\circ}$ - Não obstará a aplicação deste dispositivo o fato da pessoa auxiliada não ter praticado o crime ou não ser punivel. 
Pr. 361 - Aquele que, para frustar a ação da justiça, acolher ocultar criminoso que responda por crime comum, será punido com detenção até 3 meses ou com multa. Nenhuma pena se aplicará quando entre o criminoso e quem lhe dar asilo, existir parentesco próximo. § un. Quando o crime previsto neste art. consistir no couto e asilo, habitualmente dado a bandoleiros, malfeitores no interior do paiz, aplicar-se-á a pena de detenção por 3 meses no minimo ou a de prisão por 6 meses a 2 anos e em ambos os casos a multa. Nesta hip0tese só o parentesco no $1 .^{\circ}$ grau eximirá de pena o asilador.

Cons. 21 - Serão cúmplices..., os que derem asilo ou prestarem sua casa para reunião de assassinos e roubadores, conhecendo-os como taes e o fim para que se reunem.

Art. 188 - Ajudar alguem a assegurar-se o proveito, produto ou preço de crime, para o qual se comine pena de morte ou de reclusão e de que não haja participado o agente.

Pena - detenção ou reclusão por 1 a 4 anos.

$\S 10^{\circ}$ - Se o crime fôr punido com detenção ou multa.

Pena - multa de 200\$000 a 5:000\$000.

$\S 2^{\circ}$ - Não exclue a responsabilidade de quem prestar o auxilio o fato de não ser punivel o agente do crime.

Pr. Omisso.

Cons. Omissa.

Art 189 - Promover ou facilitar a evasăo de quem estiver legalmente preso.

Pena - detenção por 6 meses a 2 anos.

$\S 1 .^{\circ}$ - Aumentar-se-á a pena :

I - se o evadido responder por crime punido com 5 anos de reclusão, no minimo;

II - se o agente usar de ameaça ou violencia contra a pessoa ou de fração;

III - se o crime fôr cometido por autoridade ou funcionario público, responsavel pela custódia do evadido.

$\S 2 .^{\circ}$ - A pena será de reclusão por 1 a 4 anos :

I - se o evadido responder por crime punido com a morte; 
II - se o crime fôr cometido á mão armada ou por mais de duas pessoas.

$\S 30^{\circ}$ - A pena será de reclusão por 2 a 6 anos:

I - se a autoridade ou funcionario público a que alude o n. III do $\S 1 .^{\circ}$ tiver cometido o crime mediante paga ou promessa de recompensa;

II - se, acometido ou assaltado o logar, em que se encontre o preso, outro ou outros consigam evadir-se.

$\S 4 .^{\circ}-$ Punir-se-á com detenção por 3 meses a 1 ano, ou multa de 1 a 5:000\$000, a autoridade, ou funcionario, que, por seu procedimento culposo, der causa á evasão ou facilitá-la.

$\S 5 .^{\circ}$ - Diminuir-se-ão, em qualquer hipótese, as penas cominadas se, dentro em 3 meses da evasão, o agente promover a captura ou apresentação do evadido.

$\S 6 .^{\circ}$ - Punir-se-á com detenção por 3 meses a 1 ano, além daquelas em que incorrer pela violencia cometida, quem, estando legalmente preso, evadir-se ou tentar faze-lo, mediante violencia á pessoa. Diminuir-se-á a pena, se, antes da condenação, o evadido se constituir prisioneiro.

362 - Aquele que der evasão: 1) a quem estiver cumprindo pena; 2) a quem tiver sido preso em flagrante de crime inafiançavel, ou o estiver previamente por decisão judicial; 3) a quem estiver submetido a medida detentiva de segurança, será punido: a) nos casos dos nos. 1 e 2 com detenção por 6 meses no minimo, ou com prisão até 1 ano, mas a pena poderá ser livremente atenuada quando o inculpado fôr pae, filho, irmão ou cônjuge do evadido, e não tiver usado de violencia; b) no caso do n. 3 com detenção até 3 meses ou com multa. $\S$ un. Qualquer que seja a hipótese, quando se tiver usado de violencia a pena aplicavel será a de prisão até 3 anos, e a relação de parentesco da letra a será considerada atenuante. 363: Aquele que para dar evasão a sentenciados ou subtrair alguem á ação da justiça, acometer estabelecimentos em que se cumpram penas, ou se executem medidas de segurança, será punido com prisão até 3 anos, se a evasão se frustrar, e por 2 a 6 no caso contraio.

Cons. 117 - Tirar, ou tentar tirar, aquele que estiver legalmente preso, da mão e poder da autoridade, de seus agentes e subalternos, ou de qualquer pessoa do povo, que o tenha prendido em flagrante ou por estar condenado por sentença -6 meses a 1 ano. $\S$ un. Se para 
esse fim se empregar violencia ou ameaça contra a pessoa -1 a 4 anos. 128: Acometer qualquer prisão com força e constranger, carcereiros ou guardas a facilitarem a fugida dos presos: 1) se esta se verificar -2 a 6 anos; 2) se a fugida não se verificar -1 a 4 anos. 129: Fazer arrombamento na cadeia, por onde fuja ou possa fugir o preso; para esse mesmo fim praticar escalada, violencia ou usar de chaves falsas - 3 meses a 1 ano. 130: Facilitar aos presos, por meios austuciosos, a sua fugida -1 a 4 anos. 131: Consentir o carcereiro, ou pessoa a quem fôr confiada a guarda ou condução do preso, que este fuja -1 a 3 anos. 132: Deixá-lo fugir por negligencia - 6 meses a 1 ano. $\S 10^{\circ}$ Se a fugida fôr tentada, ou efetuada pelos mesmos presos serão punidos de conformidade com as disposições regulamentares. $\S 20^{\circ}$. Fugindo, porém, os presos, por efeito de violencia contra o carcereiro ou guarda -3 meses a 1 ano, além das em que incorrerem pela violencia...

Art. 190 - Promover ou facilitar a evasão de quem estiver submetido a medida detentiva de segurança, ou ocultar o evadido, ou ajudá-lo de qualquer maneira a subtrair-se á ação da autoridade.

Pena - detenção por 6 meses a 2 anos, ou multa de 2 a $5: 000 \$ 000$, ou ambas cumulativamente.

$\S 10^{\circ}$ - Aumentar-se-ão e cumular-se-ão as penas, verificada qualquer das hipóteses previstas no art. precedente, $\S 1 .^{\circ}$, ns. II $₹$ III, e $\S 20^{\circ} \mathrm{n}$. II.

$\S 20^{\circ}-\mathrm{A}$ pena será de reclusão por 2 a 6 anos, verificada qualquer das hipóteses previstas no art. precedente, $\S 2 .^{\circ} \mathrm{ns}$. I e II.

$\S 30^{\circ}-\mathrm{A}$ autoridade ou funcionario, a que competir a custódia de pessoa submetida a medida detentiva de segurança, que, por seu procedimento culposo, der causa ou facilitar a evasão, será punido com multa de 500\$000 a 5:000\$000.

$\S 4 .^{\circ}-$ Aplicar-se-á nos casos deste artigo o disposto no $\S 5 .^{\circ}$ do art. precedente.

Pr. Omisso.

Cons. Omissa.

Art. 191 - Arrebatar preso, afim de maltratá-lo, do poder de quem o tiver sob custodia.

Pena - reclusão por 1 a 4 anos. 
$\S 10^{\circ}$ - Se do crime resultar para o preso ou para a autoridade ou funcionario lesão grave ou gravíssima.

Pena - reclusão por 3 a 10 anos.

$\S 20^{\circ}-$ Se resultar a morte de qualquer deles.

Pena - reclusão por 15 a 30 anos.

Pr. 330 - Será punido com detenção por 1 a 3 meses ou com prisão por 3 meses a 1 ano aquele que, das mãos da autoridade ou funcionario público, do seu poder ou guarda... arrebatar ou tirar algum individuo legalmente preso ou detido.

Cons. 133 - Arrombar ou acometer qualquer prisão com força para maltratar os presos - 1 a 4 anos.

Art. 192 - Não haverá logar a aplicação dos disposto nos arts. $176,178,179$ e seus $\S \S 1 .^{\circ}$ e $2 .^{\circ}, 182,183$ e 185 se o agente houver praticado a ação ou omissão, constrangido pela necessidade de salvar a liberdade ou a honra própria, ou de ascendente, descendente, cônjuge, irmão, tio, sobrinho ou cunhado.

Pr. Omisso.

Cons. Omissa.

Art. 193 - Reingressar no territorio brasileiro quem tiver sido expulso por decreto judicial.

Pena - reclusão por 1 a 4 anos, executando-se nova expulsão, uma vez cumprida a pena.

Pr. Omisso.

Cons. $108 \S 10: \quad 0$ estrangeiro expulso, que voltar ao paiz, antes de revogada a expulsão, ficará pela simples verificação do fato, sujeito á pena de 2 anos de prisão, após o cumprimento da qual será novamente expulso.

Art. 194 - Exercer direito, função, cargo, profissão ou atividade econômica, de que tiver sido suspenso, durante o tempo em que vigorar a suspensão, ou de que tiver sido privado, em consequencia de decisão judicial. 
Pena - detenção por 3 meses a 2 anos, ou multa de 1 a $20: 000 \$ 000$, ou ambas cumulativamente.

Pr. Omisso.

Cons. Omissa.

\section{TITULO III}

\section{Dos crimes contra a ordem e a tranquilidade públicas}

\section{Capitulo I}

\section{Dos crimes referentes a ordem pública}

Art. 195 - Incitar diretamente o odio entre os varios grupos da população, por motivo de raça, nacionalidade ou conviç̧ões poiliticas ou religiosas, ou entre as classes sociaes, ou instigá-los á luta pela violencia.

Pena - reclusão por 4 a 8 anos.

Pr. Omisso.

Decr.-lei 431, art. $3 .^{\circ}, 10$ : Incitar diretamente o odio entre as classes sociaes ou instigá-las á luta pela violencia - 4 a 8 anos.

Art. 196 - Incitar publicamente a prática de crime ou fazer publicamente a apologia dele ou de quem o tiver praticado:

$\S 10^{\circ}$ - Se o crime a que se referir a apologia ou incitação fôr punido com a pena de morte.

Pena - reclusão por 3 a 10 anos.

$\S 2 .^{\circ}$ - Se o crime fôr punido com a pena de reclusão.

Pena - reclusão por 1 a 5 anos.

$\S 3 .^{\circ}$ - Se o crime fôr punido com detenção ou multa.

Pena detenção por 3 meses a 1 ano, ou multa de 1 a $5: 000 \$ 000$,

Pr. 369: Aquele que, como provocação indeterminada, fizer publicamente a apologia de crime cometido no paiz ou no estrangeiro, que se compreenda na qualificação do art. precedente (destruição das 
bases economicas da organização social ou politica do paiz), será punido com detenção por 3 a 9 meses, e na reincidencia com prisão por 6 meses a 2 anos.

Tratando-se de reincidente em condições de ser administrativamente expulso do paiz, poder-se-á além da prisão aplicar a expulsão.

Decr. lei 431 art. $30^{\circ}$ n. 11: Instigar publicamente a cometer qualquer dos crimes a que se refere 0 n. 14 ou publicamente fazer a sua apologia -3 a 4 anos. 19: Instigar publicamente a pratica de qualquer dos crimes definidos nos incisos $1,2,3,5$ e $7-1$ a 3 anos.

OBSERVAÇÃO. 0 projeto não reproduz o art. 17 da lei $n .38$, de 35, que, por inadvertencia, o art. $3 .^{\circ} \mathrm{n} .16$ do decr.-lei n. 431 perfilhou. Dizia o primeiro: "Incitar ou preparar atentado contra pessôa ou bens, por motivos doutrinarios, políticos ou religiosos -1 a 3 anos de prisão celular. $\S$ um. Se o atentado se verificar, a pena será a do crime incitado ou preparado". O segundo se limitou a elevar para 2 a 5 anos a pena da infração. Mas o dispositivo é inutil e desacertado. Inutil, porque não ha nenhuma razão de ordem tecnica ou de ordem política para destacar, dentre os casos de incitamento ao delito, a hipótese figurada. Desacertada por varias razões. Primeiro: não se compreende quaes os motivos doutrinarios, diversos dos políticos e religiosos, que possam inspirar o criminoso. Segundo: "preparar" atentado contra pessoas ou bens é tudo quanto ha de menos preciso, podendo abrir margem a interpretações perigosas. Terceiro: a pena cominada para o crime simplesmente incitado ou preparado será muitas vezes mais grave do que a do crime consumado... Basta considerar que os crimes de lesão leve, dano, furto, violencia privada, tem de ser punidos forçosamente com penas inferiores ás estabelecidas na Lei n. 38 e no Decr. lei n. 431. Por tudo isso não vacilo em propôr a supressão dos dispositivos.

Art. 197 - Punir-se-á com reclusão por 3 a 6 anos aquele que:

I - incitar militares á desobediencia á lei, ou á rebelião, deserção ou infração, por qualquer fórma, da disciplina;

II - distribuir ou tentar distribuir, entre soldados ou marinheiros, papel de qualquer especie, em que se contenha incitação á indisciplina; ou introduzi-lo ou tentar introduzi-lo em estabeleci. mento militar ou vaso de guerra; ou afixá-lo, aprégoá-lo ou vende-lo nas imediações de estabelecimento de caráter militar ou de logar em que os soldados se reunam ou se exercitem ou manobrem. 
Pr. 391 - Aquele que publicamente provocar militares a desobedecer á lei, violar o juramento, infringir a disciplina, subverter a hierarquia, recusar o serviço, rebelar-se ou desertar, será punido até 3 anos. Se, por força da provocação algum motim ou rebelião militar se tiver produzido a pena será agravada. § um. A sanção do art. precedente aplicar-se-á aquele que: 1) distribuir ou procurar distribuir entre soldados quaesquer papeis impressos, manuscritos, datilografados ou gravados em que se contenha incitamento direto á indisciplina; 2) lançar para dentro de qualquer estabelecimento militar ou vaso de guerra ou neles subrepticiamente insinuar ou procurar insinuar semelhantes papeis; 3) aprégoa-los, ou vende-los nas imediações de estabelecimento de caráter militar ou de logar em que os soldados se reunam, se exercitem ou manobrem. Os papeis serão confiscados.

Decr. lei 431 , art. $3 .^{\circ}$ n. 13: A. quaesquer papeis impressos, manuscritos, datilografados, mimeografados ou gravados...

Art. 198 - Provocar animosidade entre as classes armadas, ou contra elas, ou delas contra as instituiȩões civis.

Pena - 2 a 5 anos ou reclusão.

Pr. Omisso.

Decr. lei 431 , art. $3 .^{\circ}$ n. 15: Conforme ao texto.

Art. 199 - Aquadrilharem-se tres ou mais pessoas para a prática de crimes.

Pena - reclusão por 3 a 7 anos para o cabeça ou organizador; e por 1 a 5 anos para os outros.

$\S 1 .^{\circ}$ - Aumentar-se-á a pena, se, armados, os agentes percorrerem o sertão, ou as estradas, ou outros logares em que desenvolvam a sua atividade criminosa; ou se a quadrilha se valer do concurso de menores de 18 anos.

$\S 2 .^{\circ}$ - Punir-se-á com detenção por 6 meses a 2 anos, ou multa de 1 a 5:000\$000, ou ambas cumulativamente, aquele que, sabendo tratar-se de membro da quadrilha, fornecer a um deles asilo ou viveres, sem participar de qualquer fórma de sua atividade criminosa. Aumentar-se-á a pena, se os viveres ou o asilo forem fornecidos continuadamente. Não haverá logar a aplicação da pena, se o beneficiario fôr ascendente, descendente, cônjuge, irmão, cunhado, tio ou sobrinho do agente. 
Pr. 361: § un. - Quando o crime previsto neste art. consistir no couto e asilo, habitualmente dado a bandoleiros ou malfeitores no interior do paiz, aplicar-se-á a pena de detenção por 3 meses no minimo, o ua prisão por 6 meses a 2 anos, e em ambos os casos a multa. Nesta hipótese só o parentesco em $10^{\circ}$ grau eximirá da pena o asilador.

Cons. 21 - Serão cúmplices... \& $40^{\circ}$ os que derem asilo ou prestarem sua casa para reunião de assassinos ou roubadores, conhecendo-os como taes e o fim para que se reunem.

Art. 200 - Participar de associação de mais de cinco pessoas, que se reunam periodicamente, e se obriguem a ocultar á autoridade a existencia, objetivo, organização ou administração da sociedade.

Pena - detenção por 1 a 3 meses, ou multa de $300 \$ 000$ a $1: 000 \$ 000$.

$\S 10^{\circ}$ - Na mesma pena incorrerá o proprietario ou ocupante do predio, que cientemente o tiver cedido para a reunião.

$\S 2 .^{\circ}$ - Não haverá logar a aplicação da pena, quando, interrogados pela autoridade competente, os participes revelarem a verdade e fôr licito o objeto da associação.

$\S 3 .^{\circ}$ - Se forem falsas as declarações prestadas ou ilícito o objeto da associação, aumentar-se-ão e cumular-se-ão as penas, quando em outras mais graves não hajam incorrido os agentes.

Pr. 482 - Aqueles que em numero de mais de 5 pessoas se se reunirem em dias certos e logar determinado, sob o compromisso de ocultar á autoridade os seus fins, serão punidos com detenção até 1 mês ou com multa. Declarações verdadeiras embora posteriores, elidirão a pena, se os fins eram lícitos, mas, as falsas as dobram, quando ilícitos eles forem. Ao disposto neste art. estará sujeito o dono ou locatario do predio que o tiver cedido para a reunião, quando souber os fins eram ilícitos.

Cons. $382-$ Considera-se sociedade secreta a reunião, em dias certos e determinado logar, de mais de 7 pessoas que sob juramento ou sem ele, se impuserem a obrigação de ocultar á autoridade pública, o objeto da reunião, sua organização interna e o pessoal de sua administração. Aos chefes ou diretores da reunião, ao dono ou administrador da casa onde ela se celebrar -3 meses a 1 ano. $\S 10^{\circ}$ Não terá logar a imposição da pena, se se fizer á autoridade policial a declaração do fim e dos intuitos da reunião. § $20^{\circ}$ Se forem falsas as declarações e a sociedade tiver fins opostas á ordem social, a autoridade fará dispersar a reunião e os chefes ou diretores sofrerão a pena de 1 a 2 anos. 
Art. 201 - Punir-se-á com detenção por 1 mês a 2 anos, ou multa de $300 \$ 000$ a 5:000\$000, ou ambas cumulativamente, quando em pena mais grave não incorrer, aquele que:

I - em solenidade ou ato oficial, ou em assembléa ou espetáculo públicos, promover tumulto ou portar-se de modo desrespeitoso ou inconveniente;

II - em público ou lógar aberto ou exposto ao público, der falso alarme, ou provocar a explosão de petardo, ou fizer manifestação sediciosa, ou praticar outro ato capaz de suscitar pânico ou tumulto.

Pr. 355 - Será punido com detenção até 6 meses e aquele que: 1) entrar tumultuariamente no recinto de algum tribunal ou juizo, e por este modo perturbar ou interromper a sessão ou audiencia; 2) promover ou tomar parte em desordem, tumulto ou assuada, no recinto em que algum tribunal ou juizo realisar sessão ou der audiencia. 375: Serão punidos com detenção até 3 meses ou com multa aqueles que: 1) invadirem tumultuariamente o recinto de alguma das casas do Congresso Nacional, durante as suas sessões; 2) promoverem desordem, assuada e algazarra no recinto de qualquer delas, de modo a impedir a continuação do seus trabalhos; 3) resistirem á ordem de evacuar o recinto dada pelo presidente da sessão.

Cons. 109, 2. - Entrar tumultuariamente no recinto de alguma das Camaras do Congresso... 2 a 4 anos. $\S 10^{\circ}$ Se qualquer desses crimes fôr cometido contra as assembleas legislativas dos Estados metade da pena. $\S 20^{\circ}$ Se contra as intendencias ou conselhos municipaes - a terça parte da pena. 114: Levantar motim ou excitar desordem durante a sessão de algum tribunal de justiça ou audiencia de juiz singular, de maneira a impedir, perturbar ou determinar a suspensão do ato -2 a 6 meses.

\section{Capitulo II}

\section{Dos crimes referentes á tranquilidade pública}

Art. 202 - Publicar ou divulgar notícia, capaz de perturbar a tranquilidade pública, sabendo ou devendo saber que se trata de informação falsa, exagerada ou tendenciosa.

Pena - detenção por 6 meses a 1 ano. 
$\S 10^{\circ}$ - Aumentar-se-á a pena se o crime fôr cometido em tempo de guerra ou de comoģão intestina.

$\S 20^{\circ}$ - Punir-se-á com multa de $100 \$ 000$ a $500 \$ 000$ aquele que apregoe, em logar público ou aberto ou exposto ao público, periódico ou outro impresso, de modo capaz de perturbar a tranquilidade pública ou causar escandalo.

Pr. 468 - Será punido com multa ou com detenção até 15 dias aquele que: 1) espalhar boatos, publicar, difundir, ou apregoar noticias exageradas cu falsas, que possam gerar na população desassocego ou temor... \& un.: Se o fato correr durante comoção intestina, grave perturbação da ordem pública, perigo público, calamidade ou desastre, a detenção será por 1 a 3 meses mais a multa.

Cons. $320 \S 20^{\circ}-E^{\prime}$ tambem injuria.. apregoar em logares públicos a venda de gazetas, papeis impressos ou manuscritos de modo ofensivo a pessoa ou nacionalidade, certa e determinada, com o fim de escandalo e aleivosia.

Decr. 14 Julho 34, 11 - Publicar noticias falsas, ou noticiar fatos verdadeiros, umas e outros, porém, tendenciosamente, por fórma a provocar alarme social ou perturbação da ordem pública - 500\$ a 2:000\$000 ou 1 a 6 meses.

Decr.-lei 431, 3., 26 - Divulgar por escrito ou em público noticias falsas, sabendo ou devendo saber que o são e que possam gerar na população desassocego ou temor -6 meses a 1 ano.

Art. 203 - Perturbar o socego público, entregando-se a gritaria ou algazarra, ou exercendo profissão incômoda ou ruidosa em momento ou logar impróprios, ou abusando de instrumentos sonoros ou sinais acústicos, ou provocando ou não impedindo barulho produzido por animal doméstico.

Pena - multa de 100\$000 a 2:000\$000.

Pr. 469 - Será punido com multa aquele que perturbar o repouso público durante a noite ou o dos doentes durante o dia: 1) com gritos, altercações ou algazarra; 2) ou exercitando profissão ou mister incômodos ou ruidosos em hora ou logar impróprios; 3) ou abusando de campainhas, gramofones, alto-falantes ou de quaesquer outros mecanismos, instrumentos e objetos. Na reincidencia poder-se-á aplicar o confisco. § um. Quando a perturbação provier de animaes domesticos, na mesma pena incorrerá aquele que os detiver ou guardar.

Cons. Omissa. 
Art. 204 - Apresentar-se publicamente em estado de embriaguez, de modo a causar escandalo ou a pôr em perigo a tranquilidade pública.

Pena - detenção por 1 a 6 meses ou multa de $200 \$ 00$ a $2: 000 \$ 000$.

$\S$ unico - Aumentar-se-á a pena :

I - se o ato fôr praticado por quem já houver sido condenado por crime culposo contra a incolumidade pessoal ou a incolumidade pública;

II - se a embriaguêz fôr habitual.

Pr. 449 - Aquele, cuja embriaguez causar escândalo público, será recolhido pela policia até que volte ao estado normal, e punido com multa. Ao invés desta, ao ebrio habitual aplicar-se-á a medida de segurança adequada.

Cons. 395 - Apresentar-se publicamente em estado de embriaguez que cause escândalo, desordem ou ponha em risco a segurança própria ou alheia - $20 \$$ a $200 \$ 000$, o dobro em cada reincidencia. 396: Embriagar-se por hábito, de tal modo que por atos inequivocos se torne nocivo ou perigoso a si próprio, a outrem ou á ordem pública - internação por 3 meses a 1 ano em estabelecimento correcional adequado.

Art. 205 - Punir-se-á com detenção por 1 a 6 meses ou multa de $300 \$ 000$ a 5:000\$000, ou ambas cumulativamente, aquele que fornecer bebida alcoólica :

I - a menor de 18 anos;

II - a quem já ache em estado de embriagues ou quasi embriagado;

III - a quem sofrer manifestamente das faculdades mentaes;

IV - a pessoa que o agente saiba estar judicialmente proíbida de frequentar logares onde se forneçam bebidas de tal natureza.

$\S 10^{\circ}-$ Aumentar-se-ão as penas, nos casos dos ns. I, III e IV, se do ato resultar a embriaguez do consumidor.

$\S 20^{\circ}$ - Se o agente fôr o dono do estabelecimento comercial em que se der o crime, poderá o juiz acrescentar, na reincidencia, a proíbição de negociar com bebidas alcoólicas, por 3 meses a 1 ano. 
Pr. 419 - Aquele que servir ou fizer servir bebidas alcoólicas: 1) a menor de 18 anos; 2) a quem já estiver embriagado ou em via de embriagar-se; 3) a pessoa que pareça sofrer das faculdades mentaes; 4) a pessoa que o contraventor saiba estar proíbida, por sentença, de frequentar logar onde se forneçam taes bebidas será punido com multa; na reincidencia com detenção minima de 15 dias e com multa; na reiteração com estas mesmas penas e mais a interdição de comerciar a varejo com bebidas alcoólicas.

Cons. 397 - Fornecer a qualquer pessoa em logar frequente pelo público bebida ou substancia inebriante, com o fim de embriagá-la ou a quem já estiver embriagado $-100 \$$ a $500 \$ 000$. § uni. Se o infrator fồ o dono da casa comercial de que provier a bebida ou substancia inebriante - a estabelecida anteriormente, acrescida da interdição ao comercio de bebidas ou substancia inebriante, por 1 a 6 meses. 398: Será punido com a multa de $100 \$$ a $500 \$ 000$ ou o dobro da última que lhe houver sido imposta o dono da casa que, fazendo comercio de bebidas ou substancias inebriantes, as fornecer ao público, fóra das horas fixadas nas posturas municipaes ou consentir que a qualquer hora seja alguma bebida ou substancia inebriante fornecida a pessoa menor de 21 anos, ainda que destinada ao consumo de outrem.

Art. 206 - Ter como empregado menor de 18 anos em estabelecimento onde se forneçam bebidas alcoólicas.

Pena - multa de $200 \$ 000$ a $1: 000 \$ 000$.

$\S$ único - Á mesma pena ficará sujeito o responsavel pelo menor que ao fato houver prestado assentimento.

Pro. Omisso.

Cons. Omissa.

\section{TITULO IV}

\section{Dos crimes contra a economia nacional}

\section{Capitulo I}

\section{Dos crimes referentes a economia pública em geral}

Art. 207 - Participar de ajuste ou organisação tendente a estabelecer, no territorio nacional ou em parte dêle, monopolio de um ou mais ramos de produç̧ão, ou de transporte, ou de comercio, embora não se realize tal objetivo. 
Pena - multa de 10، a 100:000\$000.

$\S 1 .^{\circ}$ - Considera-se áto tendente a estabelecer monopolio todo aquele que, sem importar em progresso econômico ou tecnico, visar, mediante a eliminação da concurrencia, o aumento arbitrario de lucros, em desproporção com o capital efetivamente empregado, como sejam:

I - a destruição intencional de materias primas ou produtos agricolas ou industriaes, ou a acumulação de stocks, ou a combinação para não produzir ou não vender, tudo como o proposito de determiliar a alta de preços;

II - o abandono de plantações ou a paralisação de fabrica ou outro estabelecimento de produção, quando qualquer desses fatos decorra de indenização paga ao respectivo proprietario;

III - o acordo para a prestação de serviços abaixo do preço normal ou para a venda de productos abaixo do custo, com o intuito de suprimir a coneurrencia;

IV - o convenio pelo qual se exija do comprador que não compre de outro, ou se imponha ao revendedor preço de revenda, ou se converta uma parte do territorio nacional em mercado exciusivo de compra e venda de determinados produtos, em beneficio de determinadas pessôas, com o intuito de eliminar a concurrencia ou de produzir alta ou baixa de prȩ̧o.

$\S 2 .^{\circ}-\mathrm{A}^{\prime}$ pena cominada ficarão sujeitos:

I - os que fornecerem cientemente capitaes para a pratica do crime;

II - os que participarem do ajuste ou da organização para a prática do crime, embora não cheguem a praticá-lo.

$\S 3 .^{\circ}-$ A pessôa juridica, que do crime houver participado, responderá solidariamente pela multa, com o diretor, administrador, gerente ou socio responsavel pelo fato; podendo ser-lhe imposta a clausura do estabelecimento.

Pro. Omisso.

Cons. Omissa.

Art. 208 - Divulgar noticia falta ou tendenciosa, ou simu. lar negocio, ou usar de outro artificio fraudulento, para provocar 
a alta ou a baixa da cotação de moeda ou de mercadoria ou título negociavel em Bolsa.

Pena - detenção por 1 a 3 anos ou multa de 5 a 15:000\$000.

$\S 10^{\circ}$ - Aumentar-se-á a pena, quando do crime resultar a alta, ou baixa, da cotação.

$\S 2 .^{\circ}$ - Dobrar-se-ão e acumular-se-ão as penas :

I - Se o crime fôr cometido por brasileiro, em beneficio de interesses estrangeiros;

II - Se do áto resultar depreciação da moeda nacional ou título da divida pública, federal, estadual ou municipal, ou o encarecimento de generos de primeira necessidade;

III — Se o agente fôr corretor oficial.

Pro. Omisso.

Cons. Omissa.

Art. 209 - Punir-se-á com detenção por 3 meses a 1 ano, ou multa de 1 a 15:000\$000, ou ambas cumulativamente, aquele que provocar ou tentar provocar:

I - recusa coletiva ao pagamento de imposto;

II - retirada em massa de dinheiro depositado em caixa economica ou outro instituto oficial de credito;

III - venda precipitada ou qualquer embaraço á compra ou subscrição de titulos da divida pública.

Pro. Omisso.

Cons. Omissa.

\section{Capitulo II}

\section{Dos crimes referentes ao trabalho}

Art. 210 - Punir-se-á com detenção por 1 mês a 1 ano ou multa de 500\$ a 5:000\$000 aquele que, mediante violencia ou ameaça, constranger alguem:

I - a exercer ou não exercer industria, arte, oficio ou profissão; 
II - a trabalhar ou deixar de trabalhar durante determinado periodo ou em determinados dias;

III - a abrir ou fechar o seu estabelecimento de trabalho;

IV - a participar de parede ou paralisação de atividade ecônomica;

$\mathrm{V}$ - a não concluir contrato de trabalho com outrem, ou a não fornecer ou não adquirir de alguem materia prima ou produto;

VI - a entrar para determinada associação de classe ou deixar de pertencer a ela.

Pro. 245 - Será punido com detenção até 6 meses aquele que constranger alguem: 1) a exercer, ou a não exercer a sua industria, arte ou profissão; 2) a abrir, ou fechar o seu estabelecimento comercial ou industrial, salvo a ação da autoridade no cumprimento da lei, regulamentos e posturas municipaes; 3) a trabalhar, ou deixar de trabalhar durante um certo periodo ou em determinados dias.

Cons. 204 - Constranger, ou impedir alguem de excercer a sua industria, comercio ou oficio; de abrir ou fechar os seus estabelecimentos e oficinas de trabalho ou negocio; de trabalhar ou deixar de trabalhar em certos e determinados dias -1 a 3 meses.

Art. 211 - Suspender no todo ou em parte, o trabalho de empresa, escritorio ou estabelecimento, para impôr aos empregados modificação da convenção existente, ou impedir alteração que a convenção autorize, ou obter ou obstar aplicação diferente da convenção ou dos usos em vigor.

Pena - multa de 2 a 10:000\$000.

§ unico - Diminuir-se-á a pena, quando o ato fôr praticado tão sómente por solidariedade ou como protesto.

Pr. 246 - Punir-se-á com multa o patrão que, com o fim de forçar os seus operarios a submeterem-se a condições mais duras ou menos compensadoras de trabalho, ou de impedir que em favor deles se modifiquem as exigentes, total ou parcialmente suspender o trabalho em seu estabelecimento, fábrica ou oficina.

Cons. 204: $\S 2 .^{\circ}$ - Causar ou provocar cessação ou suspensão de trabalho, por meio de ameaças ou violencias, para o fim de impôr a operarios ou patrões, aumento ou diminuição de serviço ou salarios 1 a 2 anos. 
Art. 212 - Incorrerão em multa de $300 \$$ a $1: 000 \$$ os empregados de empresas, escritorio ou estabelecimento que, em número de tres ou mais, abandonarem coletivamente o trabalho, ou o prestarem de modo a perturbar-lhe a continuidade ou normalidade, para impôr ao empregador modificação da convenção vigente, ou impedir alteração que a convenção autorize, ou obter ou obstar aplicação diferente dos usos ou da convenção vigorante.

$\S$ unico - Diminuir-se-á a pena, quando se verifique a hipótese prevista no $\S$ unico do art. precedente.

Pro. Omisso.

Cons. $204 \S 2 .^{\circ}$ (já transcrito).

Art. 213 - Aumentar-se-ão as penas cominadas nos dois artigos precedentes e com elas se cumulará a de detenção por 3 meses a um ano, para o empregador, e por 1 a 6 meses para $o$ empregado quando qualquer dos crimes aí definidos:

I - fôr cometido em tempo de guerra ou comoção intestina;

II - obedecer a motivo de natureza politica ou ao propósito dc influir em deliberação de autoridade;

III - determinar perturbação da ordem, ou suspensão de obra publica, ou de serviço de interesse coletivo, e particularmente c de transporte, comunicação postal, telegráfica ou telefônica, assistencia médica ou farmacêutica, extinção de incendios, fornecimento de agua, luz, gaz, energia, abastecimento de gêneros alimenticios.

Pro. Omisso.

Cons. Omissa.

Art 214 - Induzir ou instigar empregadores ou empregados á cessação ou suspensão do trabalho por motivos estranhos ás condições deste ultimo.

Pena - detenção por 3 meses a 1 ano.

§ unico - Aumentar-se-á a pena, em se tratando do serviço de abastecimento da população ou outro de necessidade ou utilidade pública.

Pr. Omisso. 
Lei $\mathrm{n}, 38,18$ - Instigar ou preparar a paralização de serviços publicos ou do abastecimento da população -1 a 3 anos. § un. Não se aplicará a sanção deste art. ao assalariado n orespectivo serviço, desde que tenha agido exclusivamente por motivos pertencentes ás condiçōes de seu trabalho. 19: Induzir empregadores ou empregados á cessação ou suspensão do trabalho por motivos estranhos ás condições do mesmo - 6 meses a 2 anos.

Art. 215 - Invadir ou ocupar estabelecimento industrial, comercial ou agricola de outrem, ou dispôr de cousas aí existentes, destinadas a produção ou ao comercio, fazendo-o tão sómente com o intuito de impedir ou obstar o curso normal do trabalho.

Pena - reclusão por 1 a 3 anos e multa de 1 a 10:00\$0000.

Pro. Omisso.

Cons. Omissa.

Art. 216 - Dobrar-se-ão as penas estabelecidas nos arts. 209, $210,211,212$ e 213 para aqueles que hajam organizado, promovido ou chefiado a execução do crime.

Pro. Omisso.

Cons. Omissa.

Art. 217 - Exercer ou anunciar que exerce profissão ou atividade econômica, sem que tenha obtido autorização, ou licença da autoridade pública, nos casos em que a lei a exige, ou satisfeito as condições a que a lei subordina tal exercicio.

Pena - multa de 1:000\$ a 20:000\$000, quando mais grave não fôr a pena cominada em disposição especial.

$\S 10^{\circ}$ - Infringir determinação legal com referencia á matricula, ou á escrituração ou a qualquer materia que entenda com a industria, comercio ou atividade, que exercer.

Pena - multa de 100\$ a 20:000\$000, quando disposição especial não cominar pena mäis grave.

$\S 20^{\circ}$ - Exercer industria, comercio ou atividade econômica, durante o periodo em que, por decisão administrativa, estiver impedido de fazê-lo. 
Pena - detenção por 3 meses a 2 anos, ou multa de 1 a $20: 000000$, ou ambas cumulativamente.

Pr. 433 - Será punido com multa e na reincidencia com detenção até 30 dias e com multa aquele que, sem preencher as condições a que a lei lhes subordinem o exercicio. exercer qualquer arte, industria, mister ou profissão. 434: Aquele que exercer arte, profissão, industria ou comercio depois de haver passado em julgado a sentença que lhe interditou o exercicio, será punido com detenção por 15 dias no minimo. 435: Aquele que não observar as prescrições legaes quanto aos livros, escrituração, contabilidade e registro concernente á profissão, arte, industria ou mister que exercer, será punido com multa, salvo, quando, tratando-se de comerciante, com a infração se qualificar a falencia como culposa ou fraudulenta ou para ela, em lei especial se cominar pena mais grave. 436: Aquele que, estabelecido para vender, comprar ou permutar joias, relogios e outros objetos de valôr intrínseco, ou que o tenham pela sua antiguidade, lavor ou arte, ou para emprestar, mediante penhor de taes objetos, não mantiver devidamente escriturado o registro petente, quando exigido, será punido com multa e na reincidencia com detenção até 2 meses e com multa. 437: Aquele que, como dono ou gerente de hotel ou casa de habitação coletiva, não mantiver registro a que por lei fôr obrigado ou sonega-lo ao exame da autoridade comcontinuo das entradas e partidas dos hospedes ou pensionistas, com os seus nomes, nacionalidade, estado, profissão, procedencia ou destinação, ou que o sonegar ao exame da autoridade, quando exigido, será punido com as penas do art. precedente. 438: Aquele que autorizado a vender armas, não mantiver registro continuo das que forem vendidas, com a respectiva hora, dia, mês e ano, a individuação precisa de cada uma delas e o nome, nacionalidade e residencia do comprador, ou que sonegar - registro ao exame da autoridade competente, quando exigido, será punido com multa; na reincidencia com detenção até 2 meses e com multa, e na reiteração com as mesmas penas mais a interdição de comercio com armas.

Cons. 383 - A matrícula das oficinas impressoras e dos jornaes e outros períodicos é obrigatoria... § $10^{\circ} \mathrm{O}$ registro será feito... $\S 2 .^{\circ}$ A matricula conterá as declarações seguintes. $\S 30^{\circ} \mathrm{A}$ falta de matricula... bem como as falsas declarações serão punidas com a multa de $500 \$$ a $10: 000 \$ 000 \ldots$ \& $4 .^{\circ} \ldots$ sentença determinar o prazo... $\S 5 .^{\circ}$ De cada vez que não fôr cumprida... nova multa... podendo - juiz agravá-la até 50\%. 384: Os administradores de oficinas de tipografia... são obrigados a remeter á Eíblioteca Nacional um exemplar... 385: No caso de inobservancia... multa de $50 \$$ a $100 \$ 000 \ldots$ apreensão do exemplar... 
Art. 218 - Entregar-se alguem habitualmente á vadiagem, por aversão ao trabalho, sem que tenha meios bastantes de subsistencia; ou havê-los mediante ocupação ilícita ou imoral.

Pena - detenção por 15 dias a 2 meses.

§ unico - Suspender-se-á a execução da sentença ou da pena, se o condenado apresentar fiador idôneo que por ele se obrigue, o extinguir-se-á, quando ele provar por aquisição superviniente de meios de subsistencia.

Pr. 470 - Será punido com detenção por 15 dias a 2 meses, ou se The aplicará a medida de segurança adequada, aquele que: 1) sem rendas de que viva e sem habitação certa, por ociosidade vagabundear...

Cons. 399 - São compreendidos neste capitulo: $\S 10^{\circ}$ os individuos maiores, de qualquer sexo, que, sem meios de subsistencia por fortuna propria ou profissão, arte, oficio, ocupação legal, e honesta em que ganhem a vida vagarem pela cidade na ociosidade... \& $3 .^{\circ}$ os que tendo quebrado os termos em que se hajam obrigado á tomar ocupação, persis tirem em viver no ócio ou exercendo industria ilicita, imoral ou vedada pelas leis. $\S 4 .^{\circ}$ os compreendidos no art. 374 (aquele que se sustenta do jogo). 400: Os individuos classificados nos $\S \S 10^{\circ}, 2 .^{\circ}$ e $4 . .^{\circ}$ do art. antecedente serão condenados pela primeira infração entre os limites do minimo e o maximo de 6 meses a 2 anos de residencia na Colonia Correcional tendo-se em consideração a idade e o sexo do processado. § $10^{\circ}$ Pela mesma sentença que condenar o infrator como vadio será ele obrigado a assinar termo de tomar ocupação dentro de 15 dias contados do cumprimento da pena. $\S 2 .^{\circ}$ Os individuos classificados no $\S 3 .^{\circ}$ do art. 399 serão condenados como reincidentes á pena de 1 a 3 anos de reclusão na colonia correcional ou á deportação se forem estrangeiros. 401 A pena imposta aos infratores a que se referem os artigos precedentes ficará extinta, se o condenado provar superviniente aquisição de renda bastante para a sua subsistencia; ou suspensa se apresentar fiador idoneo que por ele se brigue. § un. A senterıça que a requerimento do fiador, julgar quebrada a fiança, tornará efetiva a condenação suspensa por virtude dela. 402: Os vadios.. que tiverem mais de 18 anos e menos de 21 serão recolhidos á colonia correcional pelo prazo de 1 a 5 anos.

Art. 219 - Mendigar, por ociosidade ou cupidez.

Pena - detenção por 15 dias a 2 meses.

$\S$ unico - Aumentar-se-á a pena se o crime fôr cometido : 
I - de modo vexatorio ou ameaçador ou fraudulento;

II - mediante simulação de molestia ou deformidade;

III - em companhia de alienado ou menor de 14 anos.

Pr. 470 - Será punido com detenção por 15 dias a 2 meses, ou se lhe aplicará a medida de segurança adequada, aquele que... mendigar em logares públicos ou franqueados ao público, sem licença de autoridade, ou por ociosidade ou cupidez explorar a caridade pública ou privada. 471: Aquele que explorar menores de 14 anos ou pessoas inimputaveis na pratica da mendicancia, será punido com detenção mínima de 1 mês. Taes sejam as circumstancias, a pena poderá ser substituida por medida de segurança. Em qualquer hipótese a sentença terá por efeito a interdição do patrio poder ou da tutela que o contraventor exercicia sobre o menor explorado.

Cons. 391 - Mendigar, tendo saude e aptidão para o trabalho 15 a 30 dias. § $10^{\circ}$ Pela mesma sentença que condenar o mendigo será ele obrigado a assinar o termo de tomar ocupação dentro de 15 dias do cumprimento da pena. § $20^{\circ}$ A pena imposta ao mendigo ficará extinta se o condenado provar superviniente aquisição ou renda bastante para sua subsistencia ou prestar fiança. § $3 .^{\circ}$ A sentença que, a requerimento do fiador, julgar quebrada a fiança, tornará efetiva a condenação suspensa por virtude dela. 392: Mendigar, sendo inhabil para tarbalhar, nos logares onde existam hospicios e asilos para mendigos -5 a 15 dias. 393: Mendigar, fingindo enfermidade, simulando motivos para armar á comiseração, ou usando de modo ameaçador ou vexatorio -1 a 2 meses. 394: Mendigar aos bandos, ou em ajuntamento, não sendo pai ou mãe, seus filhos impúberes, marido e mulher, cego ou aleijado e seu condutor. -1 a 3 meses. $\S$ un. Na reincidencia... a pena será de 1 a 3 anos... ou deportação, se... estrangeiros.

Art. 220 - Explorar a credulidade pública, mediante sortilegios, predição do futuro, explicação de sonhos ou praticas congêneres.

Pena — detenção por 1 a 6 meses e multa de 500\$ a 5:000\$.

$\S$ unico - Se do crime resultar para alguem doença mental ou nervosa.

Pena - a dos arts. 319, principio, e 320 , principio, conforme o caso.

Pr. 426 - Aquele que como profissäo ou meio de vida, explorar a credulidade pública: 1) com sortilegios, feitiços, bruxarias e praticas 
da chamada magia negra; 2) com filtros ou elixires misteriosos; 3) com a revelação do passado, predição do futuro, explicação dos sonhos, localisação de tesouros imaginarios, seja evocando espiritos, seja tirando cartas, será punido nos casos dos ns. 1 e 2 com detenção até 1 mês e do n. 3 com multa.

Cons. 157 - Praticar o espiritismo, a magia e seus sortilegios, usar de talismans e cartomancias para despertar sentimentos de ódio ou amor, inculear curas de molestias curaveis ou incuraveis, enfim, para fascinar e subjugar a credulidade pública - -1 a 6 mêses e $100 \$$ a $500 \$ 000$. § $1 .^{\circ} \mathrm{Se}$, por influencia ou em consequencia de qualquer destes meios resultar ao paciente privação ou alteração temporaria ou permanente das faculdades psiquicas - 1 a 6 anos e multa de $200 \$$ a $500 \$ 000$. § $20^{\circ}$ Em igual pena, e mais na privação do exercicio da profissão por tempo igual ao da condenação, incorrerá o médico que diretamente praticar qualquer dos atos acima referidos ou assumir a responsabilidade deles. Nas mesmas penalidades incorrerão os farmaceuticos, cirurgiões dentistas, enfermeiros e parteiras, que, habilitados para o exercicio dessas profissões, se derem ás praticas proíbidas nste artigo.

\section{Capitulo III}

\section{Dos crimes referentes á agricultura, indústria e comércio}

Art. 221 - Difundir epizootia, epifitia ou praga, expondo a perigo a pecuaria, a agricultura, ou as riquezas naturaes do país.

Pena - reclusão por 1 a 5 anos e multa de 5 a 20:000\$000.

$\S 10^{\circ}$ - Infringir determinação do poder público, tendente a impedir introdução ou difusão de epizootia, epifitia ou praga.

Pena - detenção por 15 dias a 3 meses ou multa de 1 a $5: 000 \$ 000$ ou ambas cumulativamente.

$\S 20^{\circ}-$ Se fôr culposo qualquer dos crimes previstos neste dispositivo, aplicar-se-á apenas, diminuida, a multa cominada.

Pr. 279 - Aquele que der causa ao surto epizootia entre animaes domesticados ou difundir parasita ou germen nocivo á lavoura, será p̧unido com detenção e multa.

Cons. Omissa. 
Cod. Florestal, 23 - introdução de insectos daninhos ou outras pragas, cuja disseminação nas florestas as possa prejudicar em seu valor econômico, conjunto decorativo ou finalidade própria - prisão até 5 anos e multa até 10:000\$000.

Art. 222 - Causar prejuizo á industria nacional, pondo á venda ou em circulação no país ou no estrangeiro, produtos industriaes, sob nome, marca ou sinal distintivo contrafeitos ou alterados.

Pena - reclusão por 1 a 3 anos e multa de 5 a 20:000\$000.

Pro. Omisso.

Cons. Omissa.

Art. 223 - Praticar ato de concorrencia desleal:

I - fazendo pela imprensa, ou por qualquer outro meio de divulgação, com referencia á atividade própria ou alheia, falsa afirmação de fato, capaz de crear indevidamente situação vantajosa para si mesmo, em detrimento de concorrente, ou de induzir outrem a erro;

II - prestando ou divulgando por qualquer meio informação falsa com referencia a concorrente, capaz de acarretar-lhe prejuizos á reputação ou ao patrimonio;

III - fabricando, importando, exportando, armazenando, vendendo ou expondo á venda mercadoria, com falsa indicação de procedencia, ou com o emprego de termos retificativos como sejam - tipo, especie, genero, sistema, semelhante, identico, ou outro equivalente; quer o faça na propria mercadoria, ou em seu rotulo ou envoltorio, quer o faça em fatura, circular, cartaz ou outro meio de propaganda ou divulgação;

IV - apondo o proprio nome, ou razão social, ou marca de industria ou comércio, a mercadoria de outro produtor, sem 0 consentimento deste;

$\nabla$ - atribuindo-se recompensa ou distinção fiticia ou alheia;

VI - vendendo ou expondo á venda mercadoria adulterada ou falsificada em vasilhame de outro produtor, ou utilizando-se de 
tal vasilhame para negociar com produto da mesma especie, embora não falsificado ou adulterado;

VII - prometendo ou proporcionando vantagem de qualquer especie a preposto ou empregado alheio, para que este falte a dever funcional para com o mandante ou empregador;

VIII - divulgando ou explorando segredo de fabricação ou de negocio alheios, de que houver tido conhecimento por meios ilicitos.

Pena - detenção por 3 meses a 1 ano ou multa de 1 a $15: 000 \$ 000$, ou ambas cumulativamente.

$\S 10^{\circ}$ - Punir-se-á com as mesmas penas o mandatario, preposto ou empregado para exigir ou aceitar vantagem de qualquer especie para faltar a dever funcional nos casos dos $n^{\text {os }}$ VI, VII e VIII.

$\S 2 .^{\circ}$ - Só mediante queixa se procederá nos crimes definidos neste dispositivo.

202 - Aquele que por meios desleaes, desviar em proveito proprio a clientela de outrem, será punido, mediante queixa, com detenção até 3 meses e com multa. 201: Aquele que intencionalmente causar prejuizo ao crédito de outrem, ou por meio de noticias alarmantes ou falsas gravemente o abalar no meio em que exercer o prejudicado a sua atividade profissional, será punido, mediante queixa, com detenção até 6 meses e com multa.

Decr. 24507, de 1934, art. 39 : analógo no que se refere aos ns. I, II, III, IV, V, VIII, omisso quanto ao n. VII e aos $\S$.

\section{TITULO V}

\section{Dos crimes contra a incolumidade pública}

\section{Capitulo I}

\section{Dos crimes referentes á saúde pública}

Art. 224 - Provocar epidemia, mediante a difusão de germens patogênicos.

Pena - reclusão por 12 a 20 anos. 
$\S 10^{\circ}$ - Se do crime resultar a morte de mais de uma pessôa.

Pena - reclusão por 20 a 30 anos.

$\S 20^{\circ}$ - Se o crime fôr culposo.

Pena - reclusão por 3 a 12 anos, se do crime resultar a morte de mais de uma pessôa, e reclusão ou detenção por 1 a 3 anos, no caso contrario.

Pr. 278 - Aquele que difundir bacilos, germens ou quaesquer micro-organismos patogênicos, cuja nocividade conheça ou deva conhecer, será punido com prisão até 3 anos. Esta será o minimo da pena, quando resultar da difusão a morte de alguem na epidemia. Aplicar-se-á a detenção minima de 3 meses ou a multa, no caso de culpa.

Cons. Omissa.

Art. 225 - Infringir determinação do poder público, tendente a impedir a introdução ou propagação de doénça contagiosa.

Pena - detenção por 1 mês a 1 ano, ou multa de $200 \$ 000$ a $3: 100 \$ 000$, ou ambas cumulativamente.

§ único - Agravar-se-á a pena se fôr o agente funcionario público ou pessôa que exerça profissão sanitaria.

Pr. 459 - Aquele que faltar ao dever de denunciar á autoridade competente doença contagiosa, de notificação compulsoria, será punido com multa que se lhe dobrará na reincidencia. A interdição, facultativa na reincidencia, será obrigatoria na intimação.

Cons. 378 - Deixar o médico clinico de denunciar a existencia de doentes de molestia infecciosa á autoridade competente, afim de que este possa providenciar oportunamente, na conformidade dos regulamentos sanitarios.

Art. 226 - Envenenar agua potavel de uso comum ou particular, ou substancia alimenticia ou medicinal, destinada ao consumo público.

Pena - reclusão por 5 a 15 anos.

$\S 10^{\circ}$ - Se do crime resultar a morte de alguem.

Pena - reclusão por 10 a 20 anos.

§ $20^{\circ}$ - Se do crime resultar a morte de mais de uma pessôa. 
Pena - reclusão por 15 a 30 anos.

§ $3 .^{\circ}$ - Se o crime fôr culposo.

Pena - reclusão por 3 a 12 anos, em qualquer das hipóteses previstas nos $\S \S 1 .^{\circ}$ e $2 .^{\circ}$; e, no caso de nenhuma delas se verificar, reclusão ou detenção por 1 a 3 anos.

Pr. 280 - Aquele que envenenar fontes e reservatorios de agua potavel, tanques e viveiros de peixes, gêneros e víveres destinados ao consumo público, será punido com prisão até 3 anos. Esta será o minimo da pena quando resultar do envenenamento a morte de alguem ou doença grave para varias pessôas. Aplicar-se-á a detenção mínima de 3 meses ou a multa no caso de culpa.

Cons. 161 - Envenenar fontes públicas, ou particulares, tanques ou viveiros de peixes e viveiros destinados ao consumo público -2 a 6 anos. § um. Se do envenenamento resultar a morte de alguma pessôa -6 a 15 anos.

Art. 227 - Corromper ou poluir agua potavel, de uso comum ou particular, tornando-a impropria ao consumo ou nociva á saude.

Pena - detenção ou reclusão por 1 a 3 anos.

$\S 10^{\circ}$ - Se o crime fôr culposo.

Pena - detenção por 1 a 3 meses ou multa de $300 \$ 000$ a $1: 000 \$ 000$.

$\S 20^{\circ}$ - Se do crime doloso ou culposo resultar a morte de alguem, ou lesão grave ou gravissima.

Penas - as do art. precedente $\S \S 1 .^{\circ}, 20^{\circ}$ e $3 .^{\circ}$, primeira parte.

Pr. - Aquele que poluir a agua potavel de uso comum ou particular, de modo a torná-la impropria ao consumo ou de consumo prejudicial á saude, será punido com detenção até um ano. Aplicar-se-á a multa no caso de culpa.

Cons. 162 - Corromper ou conspurcar a agua potavel de uso comum ou particular, tornando-a impossivel de beber ou nociva á saude -1 a 3 anos.

Art. 228 - Corromper, ou adulterar, ou falsificar substancia alimenticia ou medicinal, destinada ao consumo público, tornando-a nociva á saude. 
Pena - reclusão por 3 a 9 anos e multa de 5:000\$000 a $15: 000 \$ 000$.

$\S 10^{\circ}$ - Aumentar-se-á a pena, se do crime resultar morte ou lesão grave ou gravíssima para alguem.

$\S 2 .^{\circ}$ - Diminuir-se-á a pena, se o crime fôr culposo.

Pr. 282 -- Aquele que fabricar, manipular ou tratar qualquer produto, de modo que o seu uso ou consumo, provaveis e normaes, façam perigar a saude das pessoas será punido com detenção ou multa. A pena será de prisão até 3 anos, mais a multa; 1) quando o inculpado habitualmente fabricar, manipular ou tratar pela fórma acima indicada, produto destinado ao consumo público; 2) quando o fabricante manipular ou tratar, sabendo ser grave o perigo que ele acarretará á saude da pessoa que o consumir ou usar. 0 minimo da prisão será respectivamente de 2 e 3 anos, quando, verificada a hipótese do n. II, do consumo ou do uso de tal produto resultar doença grave ou a morte de alguem. Aplicar-se-á, no caso de culpa a detenção ou a multa, mas quando resultar do fato culposo qualquer das consequencias previstas na parte final da alinea precedente, as duas penas se cumularão e o minimo da detenção será de 3 meses. Em todos os casos os produtos nocivos serão confiscados e no caso de dolo a sentença será publicada.

Cons. 163 - Fabricar, alterar, dar, vender ou expôr a consumo público generos alimenticios... e que contenham ingredientes nocivos á saude ou sejam constituidos no todo ou em parte de produtos animaes degenerados ou decompostos ou de animaes ou vegetaes improprios para a alimentação humana -1 a 4 anos.

Art. 229 - Falsificar ou adulterar cousa destinada ao consumo público, não compreendida no dispositivo precedente, tornando-a nociva á saude pública.

Pena - reclusão por 1 a 5 anos ou multa de 3 a $15: 000 \$ 000$.

$\S 10^{\circ}$ - Acumular-se-ão as penas, se do crime resultar a morte ou lesão grave ou gravissima.

$\S 20^{\circ}-$ Diminuir-se-á a pena, se o crime fôr culposo

Pro. 282: (já transcrito).

Cons. Omissa.

Art. 230 - Importar ou vender, ou ter em depósito ou á venda, ou de outra fórma entregar ao consumo público qualquer das 
substancias ou cousas a que se referem os arts. 226, 227, 228 e 229 e que outrem haja envenenado, corrompido, poluido, falsificado ou adulterado, tornando-a nociva á saude.

Pena - as mesmas desses arts. e respectivos $\S \S$, conforme 0 caso.

Pr. 283 - Aquele que vender, ou expuser á venda, importar ou tiver em depósito, para vender, qualquer produto, sabendo que o seu uso ou consumo, normal ou provavel, é prejudicial á saude das pessôas, será punido com detenção até 3 meses e com multa, ou sómente com esta, no caso de culpa. Quando resultar do uso ou consumo, normal ou provavel do produto, doença grave ou morte, aplicar-se-á a pena de prisão, cujo mínimo, respectivamente, será de 2 a 3 anos, sendo o máximo de 6 .

Cons. 163 - ... vender ou expôr a consumo público...

Art. 231 - Vender, ou ter em depósito, ou á venda, ou de outra fórma entregar ao consumo substancia alimenticia, que, embora não envenenada, adulterada ou falsificada, seja nociva á saude.

Pena - reclusão por 1 a 3 anos ou multa de 500\$ a 5:000\$000.

$\S 10^{\circ}$ - Cumular-se-ão as penas se do crime resultar morte ou lesão grave ou gravissima.

§ 2.0 - Diminuir-se-á a pena :

I - se o crime fôr culposo;

II - se o adquirente ou consumidor tiver conhecimento prévio da nocividade da substancia.

Pro. Omisso.

Cons. Omissa.

Art. 232 - Punir-se-; com detenção por 1 a 3 anos ou multa de 1:000\$000 a 10:000\$000 aquele que:

I - vender, ou tiver em depósito ou á venda, ou de outra forma entregar ao consumo substancia medicinal avariada ou impe:feita ;

II - fornecer substancia medicinal, em desacordo, parcial ou total, com a receita médica, ou diversa da qual fôr declarada ou combinada. 
$\S 1 .^{\circ}$ - Aumentar-se-á a pena se o agente não fôr devidamente licenciado.

$\S 20^{\circ}$ - Aumentar-se-ão e cumular-se-ão as penas, se do crịme resultar morte ou lesão grave ou gravissima.

Pr. Omisso.

Cons. 160: Substituir o farmacêutico ou boticario, um medicamento por outro, alterar a receita do facultativo ou empregar medicamentos alterados - multa de $100 \$$ a $200 \$$ e privação do exercicio da profissão por 6 meses a 1 ano. $\S 10^{\circ}$ - Se por qualquer destes fatos fôr comprometida a saude da pessôa -15 dias a 6 meses, multa de $200 \$$ a $500 \$ 000$ e privação por 1 a 2 anos, multa de $500 \$$ a 1:000\$000, privação do exercicio. $\S 3 .^{\circ}$ Se qualquer destes fatos fôr praticado não por imprudencia, negligencia ou impericia na propria arte, e sim com vontade - as mesmas, impostas ao crime que resultar do fato praticado.

Art. 233 - Importar, ou alienar, ou, por conta propria ou alheia, ter em depósito ou expôr á venda, ou fornecer, embora a titulo gratuito, ou ministrar, ou de qualquer outra maneira entregar ao consumo substancia entorpecente, sem estar deviudamente autorizado a exercer o comercio de substancias medicinais; ou, estando devidamente autorizado a exercê-lo, praticar algum dos atos referidos, em desacordo com determinação legal.

Pena - reclusão por 1 a 5 anos e multa de 1 a 10:000\$000.

$\S 10^{\circ}$ - Punir-se-á com detenção por 6 meses a 2 anos e multa de 500 a 5:000\$000 aquele que:

I - exercendo legalmente a medicina ou a odontologia, prescrever substancia entorpecente, fóra dos casos indicados pela terapêtica, ou em dose evidentemente maior do que a necessaria, ou com infração de outra determinação legal;

II - tiver em seu poder ou sob sua guarda substancia entorpecente, sem prescrição de médico ou dentista;

III - instigar, ou induzir alguem a usar de entorpecente, sem prescrição de médico ou dentista; 
IV - utilizar local, de que tenha a propriedade, administração ou vigilancia, ou consentir que outrem se utilize dele, para uso ou guarda ilegaes de entorpecente;

$\mathrm{V}$ - concorrer de qualquer outra fórma para alimentar ou difundir o uso de substancia de tal natureza.

$\S 20^{\circ}$ - Aumentar-se-á a pena, quando a venda, administração, fornecimento ou prescrição se fizer a menor de 18 anos, ou alienado, ou toxicômano, ou em detrimento de um destes fôr praticado qualquer dos crimes previstos no $\S 1 .^{\circ}$ n. ${ }^{\circ} \mathrm{s}$ III, IV e V.

$\S 3 .^{\circ}$ - A tentativa de qualquer dos crimes definidos neste artigo equipara-se para o efeito da pena ao crime consumado.

Pr. 284 - Será punido com prisão até 3 anos e com multa aquele que, sem licença legal ou contravindo aos regulamentos sanitarios: 1) comerciar em grosso ou a varejo, estavel ou ambulantemente, com tóxicos de naturesa analgésica ou entorpecente, como sejam o ópio, a diamba, a cocaina, os seus congêneres compostos e derivados, ou qualquer outra substancia que, nos seus efeitos, se lhes equipara; 2) os detiver com o fim de fazê-los circular, clandestina ou fraudulentamente; 3) cientemente os guardar ou receber em deposito por conta de $3 .^{\circ}$; 4) os ministrar ou fornecer a alguem, embora o faça gratuitamente.

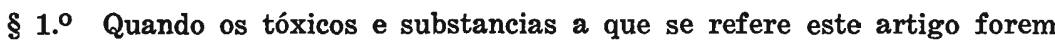
ministrados, fornecidos ou vendidos a menor de 18 anos, doente mental ou toxicómano, a pena será agravada. § $2^{\circ} \mathrm{Da}$ simples detenção, no caso do n. 2, decorre a presunção de clandestinidade e fraude, que sómente poderá ser elidida pela exibição da licença legal para comercio de tóxicos e entorpecentes. $\S 3 .^{\circ}-$ No caso do $n .^{\circ} 3$, aplicar-se-á sómente a multa ao guardador ou depositario, quando provada a sua bôa fé. 285: Aquele que, gratuita ou remuneradamente, puzer em algum local, público ou privado, á disposição de pessôas que a ele concorram para dar-se ao uso de tóxicos ou a entorpecentes, será punido com prisão até 2 anos e com multa. 286: Aquele que, fóra dos casos previstos neste capitulo, por qualquer modo concorrer para alimentar ou difundir o uso de tóxicos ou entorpecentes, será punido com detenção até 6 meses e com multa. 287: Quando qualquer dos crimes previstos neste capitulo fôr cometido por medico, farmacêutico ou dentista, ou da profissão, arte ou industria se tiver aproveitado quem as exercia para comete-lo, se aplicará a interdição adequada. 420: Aquele que frequentar local posto á disposição de quem se quizer dar ao uso de tóxicos ou entorpecentes será punido com multa ou com detenção até 8 dias. $\mathrm{Na}$ reincidencia 
aplicar-se-á somente a detenção por 8 a 30 dias. Tratando-se de intoxicado habitual aplicar-lhe-á o juiz, mediante exame médico, a medida de segurança adequada. § un. Este artigo é aplicavel áquele que fôr encontrado com qualquer das substancias ou tóxicos referidos no art. 284 e lhes não puder justifıcar o uso com prescrição médica anterior que o autorize.

Cons. 159 - Vender, ministrar, dar, trocar, ceder ou de qualquer modo proporcionar substancias entorpecentes; propôr-se a qualquer desses atos sem as formalidades prescritas pelo D. N. S. P.; induzir ou instigar por ato ou palavras o uso de qualquer dessas substancias -1 a 5 anos e multa de 1 a 5:000\$000. a) Se o infrator exercer profissão ou arte que tenha servido para praticar a infração ou que tenha servido para praticar a infração ou que tenha facilitado - além. suspensão do exercicio por 6 meses a 2 anos. b) Sendo farmacêutico o infrator - 2 a 5 anos, multa de 2 a 6:000\$000, além da suspensão... por 3 a 7 anos. c) Sendo médico ou cirurgião dentista 0 infrator, 3 a 10 anos, multa de 3 a 10:000\$000, suspensão por 4 a 11 anos. § $10^{\circ}$ - Quem fôr encontrado tendo consigo, em sua casa ou sob sua guarda, qualquer substancia tóxica, de natureza analgésica ou entorpecente, seus sáes, congêneres, compostos e derivados, inclusive especialidades farmacêticas correlatas, como taes consideradas pelo D. N. S. P., com dose superior á terapêutica determinada pelo mesmo D., e sem expressa prescrição médica ou de cirurgião-dentista, ou quem, de qualquer fórma, concorrer para dissiminação ou alimentação do uso de alguma dessas substancias - 3 a 9 meses e multa de 1 a 5:000\$000. Em circunstancias especiaes, mediante declaração de médico regularmente inscrito no D. N. S. P., poderá ser expedida a dose terapêutica acima determinada. devendo em taes casos ser apresentada pelo proprio medico á autoridade sanitaria, a justificação do emprego do entorpecente. $\S 2 .^{\circ}-$ Aproveitar-se ou consentir que outrem se aproveite, por qualquer motivo ou para qualquer fim, de estabelecimentos, edificios ou locaes de que tenha propriedade, guarda ou administração, para facultar aí a alguem o uso ou guarda de qualquer substancia entorpecente sem as formalidades da lei - as do $\S 1 .^{\circ} .$. o estabelecimento em que ocorra algum dos fatos previstos no dispositivo supra será fechado definitivamente ou pelo prazo mínimo de 1 ano. $\S 3 .^{\circ} \mathrm{O}$ médico ou cirurgião dentista que prescrever o uso de qualquer substancia entorpecente com pretenção das formalidades legaes, em dose evidentemente mais elevada que a necessaria, ou fóra dos casos indicados pela terapêutica, além da suspensão determinada na letra $a$ deste art. e da demissão determinada no $\S 5 .^{\circ}$, incorrerá... 3 a 12 meses e multa de 2 a 5:000\$. $\$ 4 .^{\circ}$ Importar entorpecentes por via aerea ou postal ou com qualquer outra inobservancia das formalidades legaes — anos, além das fiscaes. Os tripulantes de embarcação ou aeronave que auxiliarem, facilitarem ou consentirem na 
importação ou despacho... co-autores: $\S 5 .^{\circ}$ Os infratores dos arts. 16 e 21 do dec. 20.930 , de 32 , incorrerão nas penas do $\$ 2 .^{\circ} \mathrm{A}$ infração de qualquer dos dispositivos do referido dec. que não tenha pena especialmente estipulada, será punida com a multa de 1 a 5:000\$000, além das penas de prisão de 6 meses a 2 anos no caso de reincidencia. Em todos os casos do cit. dec., se o infrator exercer função pública, será suspenso por tempo indeterminado, com perda de todos os vencimentos, logo que denunciado; se definitivamente condenado, perderá a função aludida, e, se esta fôr em serviço ou repartição sanitaria, a pena será majorada de $1 / 6$. $\$ 6 .^{\circ}$. A procura da satisfação de prazeres sexuaesl nos crimes de que trata este artigo, constituirá circunstancia agravante. 3 7. Será excluido e terá a matricula trancado pelo tempo na pena em que incorrer e por mais 1 ano o aluno de estabelecimento de ensino. de qualquer gráu, publico ou particular, condenado por crime previsto neste art. $\S 80^{\circ}$ Nos casos previstos neste art. a tentativa é equiparada ao crime consumado, cessando, quer para os efeitos das penas quer para os do processo, toda distinção entre crime e contravenção. As substancias que servirem para a prática da infração serão confiscadas e entregues ao D. S. P. $\S 9 .^{\circ}$ Todas as penas deste art. serão aplicadas em dobro nos casos de reincidencia. § 10 . Serão expulsos do territorio nacional os estrangeiros condenados como reincidentes. $\S 11$. Incorrem como autores nas penas estabelecidas neste art. o portador, o entregador ou qualquer outra pessôa cuja participação no trafico das substancias aludidas se verificar pelo modo previsto no art. $21 \S 10^{\circ}$

Art. 234 - Punir-se-á com detenção ou reclusão por 1 a 3 anos e multa de 1 a 5:000\$000 aquele que, embora a titulo gratuito:

I - sem estar legalmente autorizado, ou excedendo os limites da autorização legal que tiver, exercer a medicina, em qualquer de seus ramos, a arte dentaria ou a farmácia;

II - embora legalmente habilitado ao exercicio de qualquer das referidas profissões:

a) anunciar ou prometer a cura em prazo prefixado ou por meio secreto ou infalivel;

b) acobertar com o proprio nome ou assumir a responsabilidade de ato relativo ao exercicio da medicina, odontologia ou farmacia por quem não estiver legalmente habilitado a praticá-lo.

$\S$ unico - Incorrerá no n. I deste artigo aquele que habitualmente 
I - prescrever, administrar ou aplicar substancia destinada a curar ou usar de gestos, palavras ou qualquer outro meio com finalidade curativa;

II - fizer ou prontificar-se a fazer diagnostico de doença ou indicação de tratamento.

III - praticar exame ou análise de qualquer especie, tendente á verificação de circunstancia relativa á saude alheia.

Pr. 433 - Será punido com multa e na reincidencia com detenção até 30 dias e com multa aquele que sem preencher as condições a que a lei lhes subordinou o exercicio: 1) exercer qualquer arte, industria, mistér ou profissão; 2) exercer profissão liberal ou por meio de imprensa ou de indicações fixas destinadas ao público anunciar que a exerce $\S$ um. As penas da reincidencia serão aplicadas na $1 .^{\mathrm{a}}$ infração quando do exercicio da profissão se puder originar perigo comum. No caso do n. 2 os letreiros ou placas serão apagados ou confiscados, imputando-se ao contraventor a respectiva despesa como custas.

\section{Capitulo II}

\section{Dos crimes referentes a segurança dos meios de comunicação e transporte e outros serviços públicos}

Art. 235 - Impedir ou perturbar serviço ferroviario:

I - destruindo ou danificando, total ou parcialmente, a linha ferrea ;

II - danificando ou desarranjando máquina, veículo, aparelbo ou qualquer parte do material fixo ou rodante;

III - colocando na linha obstáculo á circulação de trens;

IV - intervindo indebitamente na abertura de chave de desvio ou comunicação, ou na transmissão de aviso ou sinal, ou interrompendo o funcionamento de telégrafo ou telefone do uso da ferrovia;

$\nabla$ - praticando ato de outra natureza capaz de ocasionar desastre. 
Pena - detenção por 6 meses a 3 anos ou multa de 2 a $10: 000 \$ 000$, ou ambas cumulativamente.

$\S 10^{\circ}$ - Se do crime resultar desastre.

Pena - reclusão por 3 a 10 anos e multa de 2 a $20: 000 \$ 000$.

$\S 2 .^{\circ}$ - Por ferrovia se entende, para os efeitos deste artigo, qualquer via de comunicação sobre trilhos ou por meio de cabos aéreos, em que circulem veículos movidos a vapor, eletricidade ou outro meio de tração mecânica.

Pr. 290 - Será punido com prisão por 1 a 5 anos aquele que causar desastre ferroviario. O minimo da pena será de 3 anos e o seu máximo o genérico, quando, para provocar o desastre, tiver o inculpado: 1) danificado o material fixo ou rodante da via férrea ou diminuido a sua resistencia ou eficiencia; 2) inutilisado instalações, aparelhos, e instrumentos de sinaes ou alterado o seu funcionamento; 3) transmitido aviso falso sobre o movimento dos trens; 4) causado a morte de alguem ou grave lesão corporal, ou lesões corporaes em diversas pessôas ou prejuizo material consideravel. 296: $\mathrm{Na}$ aplicação dos arts. deste capitulo ter-se-á em atenção o seguinte: 1) na expressão estrada de ferro ou via ferrea se compreende qualquer via de comunicação e transporte sobre trilhos metálicos fixos, movida a vapor, eletricidade ou outro qualquer meio mecânico; 2) a estrada de ferro particular, de estabelecimentos industriaes ou agricola, quando utilizada na condução do respectivo pessoal, será considerada como estrada de ferro pública; 3) quando utilizados. na condução das pessoas, os omnibus automoveis e qualquer serviço ambulante, por meio de cabos, entre altitudes, equiparam-se ás estradas de ferro particulares a que se refere o n. 2.

Cons. 149 - Danificar ou desarranjar qualquer parte da estrada de ferro, maquinas, veículos, instrumentos e aparelhos que sirvam ao seu funcionamento; colocar sobre o leito ou trilhos um obstáculo qualquer que embarace a circulação do trem ou o faça descarrilar; abrir ou fechar as chaves de desvio ou comunicação; fazer sinaes falsos ou praticar qualquer ato de que resulta ou possa resultar desastre - 6 meses a 1 ano e multa de 5 a $20 \%$. $\S 10^{\circ}$ - Se o desastre acontecer - 1 a 3 anos e a mesma multa. $\S 20^{\circ}$ - Se do desastre resultar a morte de alguem -6 a 15 anos. $\S 3 .^{\circ}$ - Se alguma lesão corporal nas. especificadas no art. $304-3$ a 7 anos.

Art. 236 - Causar submersão ou naufragio de embarcação, ou queda ou destruição de aeronave, de propriedade do agente, expondo a perigo a vida, saúde ou patrimonio de outrem; ou causar 
a queda ou destruição de aeronave, ou submersão no naufragio de embarcação de propriedade alheia.

Pena - reclusão por 5 a 12 anos e multa de 2 a $20: 000 \$ 000$.

Pr. 294 - Aquele que, fazendo ilegalmente afundar ou encalhar alguma embarcação, destruindo-a, danificando-a ou inutilizando-a, puzer em perigo a vida ou a saude das pessoas será punido com prisão por 2 a 6 aons.

Cons. 144 - Praticar em embarcação de qualquer natureza, propria ou alheia, em viagem ou em ancoradouro, qualquer abertura que possa produzir invasão de agua suficiente para fazê-la submergir - 2 a 6 anos e multa de 5 a $20 \%$. $\S$ un. O proprio dono não será isento das penas deste art., sem provar que a embarcação já estava em condições de inavegabilidade e que do arrombamento por ele praticado não poderia resultar perigo comum ou prejuizo de $3 .^{\circ} 146$ : - Quando... de qualquer dos meios de destruição, especificados nos diferentes arts. deste capítulo, resultar a morte ou lesão corporal de alguma pessôa que no momento do acidente, se achar no logar, serão observadas as seguintes regras: no caso de morte: - 6 a 15 anos; no de alguma lesão corporal das especificadas no art. $304-3$ a 7 anos. 148: Todo aquele que por imprudencia... causar.. qualquer dos acidentes de perigo comum... 1 a 6 meses e multa de 5 a $20 \%$. § um. Se do incendio resultar a alguem a morte -2 meses a 2 anos.

Art. 237 - Fóra dos casos previstos nos arts. precedentes, destruir ou danificar, total ou parcialmente, via ou obra destinada á circulação pública ;ou remover ou inutilizar cousa que sirva para lhe garantir a segurança; ou impedir de outra fórma a circulação por terra, por agua ou pelo ar; ou perturbá-la, mediante sinais enganosos ou de qualquer outra maneira.

Pena - detenção por 6 meses a 3 anos ou multa de 2 a $10: 000 \$ 000$ ou ambas cumulativamente.

$\S$ único - Se do crime resultar desastre.

Pena - reclusão por 3 a 10 anos e multa de 2 a 20:000\$000.

Pr. 288 - Aquele que, impedindo ou embaraçando a circulação pública por terra, por agua ou pelo ar, puzer em perigo a vida ou a saude das pessoas, será punido com detenção até 6 meses ou com prisão até 1 ano. A pena será de prisão por 1 a 5 anos, se do fato resultar 
desastre... Para todos os casos compreendidos neste art. a multa poderá ser cumulada. 289: Aquele que alterando as condições normaes da estrada pública ou da via pública de comunicação, impossibilitar ou tornar perigoso o trânsito ,será punido com detenção até 6 meses ou com prisão até 1 ano. As alineas do art. precedente são aplicaveis, e o inculpado tambem está incurso na penalidade da primeira delas, quando tiver danificado ou destruido obras de arte de alguma estrada ou via pública, inutilizado ou removido qualquer aparelho indispensavel á segurança das mesmas. 293: Aquele que sobre escolhos, arrecifes, bancos de areia ou eminencias que dominam o mar, acender fogos, fingindo faróes, ou usar de qualquer artificio capaz de desviar os navegantes ou de arrastá-los a naufrágio e perdimento, será punido com prisão por 1 a 5 anos. Aplicar-se-á detenção até 6 meses ou a multa no caso de culpa.

Cons. 152 - Destruir ou danificar qualquer parte de estrada ou via de comunicação de uso público, obstando ou interrompendo o trânsito por ela; remover ou inutilisar os objetos destinados a garantir a sua segurança - 6 meses a 2 anos - 143: Acender fogos sobre escolhos, arrecifes, bancos de areia ou outros sitios perigosos que dominem o mar, fingindo faróes, ou praticar outros artificios para enganar os navegantes e atrair a naufragio qualquer embarcação -2 a 6 anos e multa de 5 a $20 \%$.

Art. 238 - Se de qualquer dos crimes definidos nos dispositivos precedentes resultar lesão grave ou gravíssima, a pena será de reclusão por 7 a 15 anos; e de reclusão por 10 a 30 anos, se resultar a morte de alguem.

$\S$ único - Se qualquer de taes crimes fôr culposo, aplicarse-ão as seguintes penas:

I - multa de 1 a 5:000\$, se do crime não resultar desastre;

II - multa de 1 a 5:000\$000, ou detenção por 6 meses a 2 anos, ou ambas cumulativamente, na hipótese contrária.

III - multa de 2 a 10:000\$000 e detenção por 1 a 3 anos, se resultar, para alguem, lesão grave ou gravíssima.

IV - multa de 3 a 20:000\$000 e reclusão por 2 a 5 anos, se resultar a morte de alguem.

Pr. 288 - 3 a 9 anos, no caso de morte ou lesão grave, ou lesões em diversas pessôas ou prejuizo material consideravel. No caso de culpa, detenção por 3 meses no mínimo. 
Cons. 149 e 151 - 3 a 7 anos, no caso de lesão grave; 6 a 15 anos, no de morte; 1 a 6 meses, no de culpa; 6 meses a 2 anos, no de morte por culpa.

Art. 238 - Atirar projetil contra veículo em movimento, destinado ao transporte de passageiros, por terra, por agua ou pelo ar.

Pena - detenção por 1 mês a 1 ano ou multa de $200 \$$ a 2:000\$000, além da pena em que incorrer pelo resultado.

Pr. 291 - Aquele que lançar corpos contundentes ou projeteis contra veículos em movimento, destinado ao transporte público por terra, por agua ou pelo ar, será punido com detenção por 3 meses no mínimo, ou com prisão até 1 ano.

Cons. 150 - Nas mesmas penas e guardadas as mesmas distinções incorrerá aquele que arremessar projeteis ou corpos contundentes contra um comboio de passageiros em movimento.

Art. 240 - Abandonar voluntariamente o posto durante o serviço, antes de chegar ao termo da viagem ou ao logar determinado no contrato, empregado de navio, trem, aeronave ou veículo de transporte público, expondo a perigo a vida, saude ou patrimonio alheios.

Pena - detenção por 3 meses a 1 ano, ou multa de 1 a $5: 000 \$ 000$ ou ambas, cumulativamente.

Pr. Omisso.

Cons. Omissa.

Art. 241 - Atentar, de qualquer maneira, contra a segurança ou o funcionamento normal dos serviços de distribuição de agua, luz, força, calôr ou outro de necessidade publica.

Pena - detenção por 6 meses a 2 anos ou multa de 2 a $10: 000 \$ 000$ ou ambas cumulativamente.

$\S 10^{\circ}-\mathrm{Em}$ iguaes penas incorrerá aquele que:

I - interromper ou perturbar serviço telefônico ou telegrafico;

II - impedir ou embaraçar o restabelecimento do serviço.

$\S 2 .^{\circ}$ - Dobrar-se-ão e acumular-se-ão as penas se o crime fôr cometido em tempo de comoção intestina ou de guerra. 
Pr. 292 - Será punido com detenção até 6 meses ou com multa aquele que: 1) impedir ou embaraçar serviço publico destinado á segurança das comunicações entre as pessoas, por via terrestre, aérea ou submarina, por sinaes gráficos ou transmissão oral; 2) impedir ou embaraçar o funcionamento de serviços e instalações destinados á distribuição pública de agua, energia e luz. A pena será a de prisão até 3 anos e a multa poderá ser cumulada, quando, para impedir ou embaraçar o serviço, se tiver usado de violencia ou de ameaças contra as pessôas ou danificando as cousas.

Cons. 153 - Danificar as linhas telegráficas da Nação ou dos Estados; derrubar postes, cortar fios, quebrar isoladores, cortar ou arrancar madeiras plantadas ou reservadas para o serviço das linhas, e em geral causar, por qualquer modo, dano aos respectivos aparelhos - 6 meses a 2 anos e multa de 5 a $20 \%$. $\S 1 .^{\circ}$ Se os atos, precedentemente mencionados, forem praticados por descuido ou negligencia - 5 a 30 dias. $\$ 20^{\circ}-$ Se deles resultar interrupção intencional do serviço do telégrafo -1 a 3 anos e a mesma multa. $§ 30^{\circ}$ - Se a interrupção do serviço fôr causada, em caso de comoção intestina ou guerra externa, nas linhas por onde tenham de ser transmitidas as ordens e comunicações das autoridades legaes -2 a 4 anos e a mesma multa -154 : Nas mesmas penas incorrerá aquele que perturbar a transmissão dos telegramas ou interceptá-los por meio de derivação estabelecida por fio preso ao fio do telégrafo. § un. Para os efeitos da lei penal são equiparados aos telégrafos os telefones de propriedade da Nação ou dos Estados, ou destinados ao serviço público.

\section{Capítulo III}

\section{Da pirataria}

Art. 242 - Punir-se-á com reclusão por 5 a 15 anos aquele que :

I - sem autorisação de potencia beligerante ou sem que 0 navio de que se utilize pertença á marinha de guerra de governo reconhecido, praticar, no mar ou em aguas do Brasil, ato de depredação ou violencia contra navio ou pessôa ou cousa que nele se encontrem;

II - abusando de carta de corso legitimamente concedida, praticar hostilidade contra navio brasileiro ou de nação que não esteja autorizado a atacar; 
III - usando de fraude ou violencia contra o comandante, apoderar-se do navio ou daquilo que pertencer á equipagem;

IV - entregar a pirata ou inimigo o navio, ou a carga, ou aquilo que á equipagem pertencer;

$\nabla$ - opuzer-se, mediante violencia ou ameaça, a que o navio seja defendido pelo comandante ou pela tripulação, quando atacado por inimigo ou pirata;

VI - por conta própria ou alheia, equipar navio destinado á pirataria ;

VII - sendo brasileiro ou residente no Brasil, traficar com pirata, ou tiver com ele entendimento prejudicial ao paiz, ou prestar-lhe auxilio de qualquer especie;

VIII - comandar navio armado, trazendo documento expedido por mais de uma potencia;

IX - cometer hostilidade debaixo de bandeira, que não seja a la potencia de que tiver recebido carta de corso.

$\S 1 .^{\circ}$ - A pena será de reclusão por 10 a 30 anos, se dos atos de violencia ou hostilidade, a que se refere este dispositivo, resultar a morte de alguem.

$\S 2 .^{\circ}$ - Incorrerão na pena de reclusão por 4 a 12 anos $\theta$ por 2 a 6 anos, respectivamente, o comandante e quem fizer parte de equipagem de embarcação que navegue armada, sem passaporte, matrícula da equipagem e outros documentos comprobatorios da legitimidade da viagem.

Pr. 295 -- Aquele que, em aguas brasileiras, praticar atos de pirataria contra alguma embarcação nacional ou extrangeira, seus tripulantes, passageiros, ou carga, será punido com prisão por 2 anos, no mínimo.

Cons. 104 - Exercitar a pirataria, e este crime julgar-se-á cometido: $\S 10^{\circ}$ - praticando no mar qualquer ato de depredação e violencia contra brasileiros ou contra súbditos ou nação contra a qual o Brasil não esteja em guerra; $\S 2 .^{\circ}$ abusando da carta de corso, legitimamente soncedida, para praticar sem estar autorizado, hositlidades contra navios brasileiros ou de outras nações; § $3 .^{\circ}$ - aposando-se alguem, por meio de fraude ou violencia contra o respetivo comandante, do navio, ou cuja 
equipagem fizer parte; $\S 4 .^{\circ}$ - entregando a piratas ou inimigo o navio a cuja equipagem pertencer; $\S 5 .^{\circ}$ - opondo-se alguem, por ameaças ou por violencia, a que o comandante ou tripulação do navio o defenda em ocasião de ser atacado por piratas ou por inimigo - 5 a 15 anos. $\S 6 .^{\circ}$ - aceitando carta de corso de governo estrangeiro sem a competente autorização 2 a 6 anos. 105: Pena igual á estabelecida para os 5 primeiros $\S \S$ do art. antecedente se imporá: $\S 10^{\circ}-$ aos estrangeiros que cometerem contra navios brasileiros depredação ou violencias em tempo de guerra, sem estarem munidos de carta de corso; $\S 20^{\circ}$ a toda comandante de embarcação que cometer hostilidade debaixo de bandeira que não seja da nação ou que tiver recebido carta de corso. 106: Tambem cometerá crime de pirataria: $\S 10^{\circ}$ o que fizer parte da equipagem de qualquer embarcação que navegue armada, sem ter passaporte, matricula de equipagem ou outros documentos que provem a legitimidade da viagem. - Ao comandante - 4 a 12 anos; - ás pessôas da equipagem - 2 a 6 anos. $\S 2 .^{\circ}$ o que, residindo dentro do paiz, traficar com piratas conhecidos ou lhes fornecer embarcações, provisões, munições ou qualquer outro auxilio, ou entretiver com eles inteligencia que tenham por fim prejudicar o país. $\$ 3 .^{\circ}$ a todo comandante de navio armado que trouxer documento passado por dois ou mais governos diferentes.

\section{Capítulo IV}

\section{Do incendio e de outros crimes de perigo comum}

Art. 243 - Incendiar cousa propria, expondo a perigo a vida, saude ou patrimônio de outrem, ou incendiar cousa alheia.

Pena - reclusão por 3 a 6 anos e multa de 2 a 10:000\$000.

$\S 10^{\circ}$ - Aumentar-se-á a pena :

I - se o agente expuser cientemente a perigo a vida ou saude de alguem;

II - se o crime fôr cometido com o intuito de haver em proveito próprio ou alheio, indenização ou outra vantagem pecuniaria;

III - se o incendio fôr :

a) de edificio publico, ou destinado a uso publico, ou a obra de assistencia social ou de cultura;

b) de aeronave ou navio; 
c) de estaleiro, estação ferroviaria ou aerodromo, ou oficina cu dependencia deles;

d) de poço petrolifero ou carbonifero ou galeria de mineração;

e) de fábrica ou depósito de explosivos, combustiveis ou inflamaveis;

f) de bosque, mata ou floresta.

$\S 20^{\circ}-$ Se o incendio fôr culposo:

Pena — detenção por 1 a 3 anos, ou multa de 1 a 10:000\$000, que, no caso do incendio ser de qualquer das cousas especificadas no $§ 10^{\circ}$ III deste artigo, serão impostas cumulativamente.

Pr. 272 - Aquele que causar incendio será punido com prisão. 0 minimo da prisão será de 3 anos, quando o criminoso cientemente tiver posto em perigo a vida ou a saude de alguem, ou quando tiver causado - incendio; 1) de edificios, monumentos, registros e arquivos públicos; 2) de edificios destinados ao culto religioso, á beneficencia pública, á cultura d espirito, cientifica, literaria ou artistica; 3) de edificios ou habitação coletiva ou em que habitualmente trabalhem numerosas pessôas; 4) de navios da marinha de guerra mercante nacionaes ou dos estrangeiros ancorados em porto brasileiro; 5) de estaleiros, arsenaes, depositos de material bélico, fortificações e quarteis; 6) de aerodromos, estações ferroviarias ou edificios destinados a construcção, reparação ou guarda dos respectivos aparelhos, maquinismos e material; 7) de depositos ou reservatórios de explosivos, combustiveis ou inflamaveis; 8) de poço petrolifero ou carbonifero ou galeria de mineração; 9) de matas e florestas. Se o incendio fôr culposo, aplicar-se-á a detenção até 6 meses, podendo cumular-se a multa. 273: Aquele que causar o incendio da cousa propria ou da cousa alheia, de conivencia com o dono, para auferir lucro ou fazer jús a premio ou indenização, será punido com prisão até 3 anos. Esta será o minimo da pena, quando o inculpado, cientemente, tiver posto em perigo a vida de alguem ou quando as consequencias do incendio forem graves.

Cons. 136 - Incendiar edificio ou construção de qualquer natureza, própria ou alheia, habitada ou destinada á habitação ou a reuniões publicas ou particulares, ainda que o incendic possa ser extinto logo depois de sua manifestação e sejam insignificantes os estragos produzidos - 2 a 6 anos e multa de 5 a $20 \%$ do dano causado. Incluem-se as embarcações ou navios; 5) os veículos de estradas de ferro pertencentes a comboio de passageiros, em movimento ou na ocasião de entrar em muvitação: 1) os armazens; 2) as oficinas; 3) as casas de banho e natação; 4) na significação dos termos "construção habitada ou destinada á habi- 
mento; 6) as casas de máquinas, armazens e edificios dos estabelecimentos agricolas. § un. 0 próprio dono não ficará isento das penas deste artigo, sem provar que o objeto por ele incendiado já não tinha algum dos destinos ou usos especificados e que do incendio não poderia resultar perigo comum, ou prejuizo de terceiro. 137: Nas penas do art. precedente incorrerão: 1) aquele que incendiar objetos colocados em logar de modo seja facil a comunicação do fogo aos edificios e construções especificados no mesmo art., se acontecer que o incendio efetivamente se propague e qualquer que seja a destruição causada; 2) aquele que destruir os mesmos edificios ou construções, por emprego de minas, torpedos, maquinas ou instrumentos explosivos. 138: Se os edificios ou construções não forem habitados ou destinados á habitação e não pertencerem ao autor do crime -1 a 3 anos e multa de 5 a 20\%. 139: Incendiar edificios, construções, depositos, armazens, arquivos, fortificações, arsenaes, embarcações ou navios pertencentes á Nação -2 a 6 anos e multa de 5 a $20 \%-140$ : Incendiar o proprio dono qualquer das cousas precedentemente especificadas, com o proposito de crear um caso de responsabilidade contra terceiro ou defraudar os direitos de alguem -1 a 6 anos e multa de 5 a 20\%. 141: Incendiar plantações, colheitas, lenha cortada, pastos ou campos de fazenda de cultura ou estabelecimentos de creação, matas ou florestas, pertencentes a terceiro ou á Nação -1 a 3 anos e multa de 5 a 20\$. 148: Todo aquele que, por imprudencia, negligencia ou impericia na sua arte ou profissão ou por inobservancia de disposições regulamentares, causar um incendio... 1 a 6 meses e multa de 5 a $20 \%$ - $\S$ un. Se do incendio resultar a alguem morte 2 meses a 2 anos - 155: Se os crimes previstos... forem praticados por meio de bombas ou dinamite, ou de outros explosivos eguaes ou semelhantes em seus efeitos aos da dinamite -2 a 8 anos.

Art. 244 - Punir-se-á com reclusão por 1 a 5 anos e multa de 1 a 5:000\$000 aquele que, em prédio seu, com risco para a vida, saude ou patrimonio de outrem, ou em prédio alheio:

I - remover, destruir ou inutilisar obstáculo natural ou obra destinada a impedir inundação ou desmorọnamento;

II - praticar ato tendente a provocar o desabamento total ou parcial de construção.

$\S 10^{\circ}$ - Aumentar-se-á a pena se o desastre se verificar.

$\S 2 .^{\circ}-$ Em qualquer das hipóteses previstas neste dispositivo, a pena será de detenção por 3 meses a 2 anos, ou multa de $500 \$$ a 5:000\$000 ou ambas cumulativamente, se o crime fôr culposo. 
Pr. 274 - Será punido com prisão até 3 anos aquele que puser em perigo a vida ou a saude das pessoas ou a propriedade de outrem: 1) - provocando inundação; 2) fazendo total ou parcialmente, desabar edificio ou construção, ou determinando deslocamento de terra... 5) intervindo em obras de proteção e defesa contra elementos e forças naturaes. Aplicar-se-á a detenção até 6 meses ou ambas cumuladas no caso de culpa.

Cons.: 142 - Causar a inundação da propriedade alheia, ou expô-la a esse ou outro perigo, abrindo comportas, rompendo represas, açudes, aquedutos, ou destruindo diques ou qualquer obra de defeesa comum, 1 a 3 anos e multa de 5 a $20 \%$.

Art. 245 - Expôr a perigo a vida, saude ou patrimonio de outrem, colocando, ou lançando ou fazendo explodir bomba ou outro engenho de dinamite ou de substancia de efeitos análogos.

Pena - reclusão por 2 a 5 anos e multa de 1 a $5: 000 \$ 000$.

$\S$ único - Aumentar-se-á a pena :

I - quando o agente expuser a perigo a vida ou saúde de mais de uma pessôa;

II - quando visar ou atingir qualquer das cousas enumeradas no art. $252 \S 10^{\circ}$ n..$^{\circ}$ III, $a, b, c, d, e$.

Pr. 276 - Aquele que puzer em perigo a vida ou a saúde das pessôas, ou a propriedade de outrem, colocando, lançando ou fazendo explodir bomba de dinamite ou doutra substancia, que nos seus efeitos se lhe equipare, será punido, quando em pena mais grave não incorrer, com prisão por 1 a 3 anos. 0 minimo da prisão será de 3 anos, quando a cousa ou o local visados ou atingidos se compreenderem na enumeração da alinea do art. 272 , ou quando se tiver posto em perigo a vida ou a saude de varias pessôas.

Cons. - Fazer explodir em edificios publicos ou particulares, nas vias publicas ou logares franqueados ao público, bombas de dinamite ou de outros explosivos iguaes ou semelhantes em seus efeitos aos da dinamite -1 a 4 anos. 155: Colocar nos logares indicados no art. anterior bombas de dinamite ou de outros explosivos iguaes ou semelhantes em seus efeitos aos da dinamite -6 meses a 2 anos.

Art. 246 - Expôr a perigo a vida, a saude ou patrimonio de outrem, causando explosão não compreendida no dispositivo precedente, ou servindo-se de gaz tóxico ou de substancia inflamavel. 
Pena — detenção ou reclusão por 1 a 3 anos e multa de $500 \$ 000$ a $5: 000 \$ 000$.

$\S 1 .^{\circ}$ - Aumentar-se-á a pena, ocorrendo qualquer dos casos meneionados no $\S$ unico do art. 245.

$\S 20^{\circ}-\mathrm{Em}$ qualquer hipótese diminuir-se-á ou substituir-se-á a pena por multa de 1 a 10:000\$000, se o crime fôr culposo.

Pr. 275 - Aquele que puzer cientemente em perigo a vida ou a propriedade de outrem, usando de explosivos, inflamaveis ou substancias toxicas será punido com prisão por 2 anos no minimo, ou com detenção até 6 meses e multa, se sómente responder por culpa.

Cons. Omissa.

Art. 247 - Se de qualquer dos crimes definidos nos arts. 243 , 244, 245 e 246, resultar lesão grave ou gravissima, ou morte, aplicar-se-á o disposto nos arts. 320 , pr., 319, pr., e $311 \S 1 .^{\circ}$, respectivamente.

Pr. 275: e outros - diferente.

Cons. - diferente.

Art. 248 - Expôr a perigo a vida ou patrimonio alheios:

I - causando, por erro no projéto ou na execução, desabamento parcial ou total de edificio ou obra que construir.

II - omitindo as providencias reclamadas pelo estado ruinoso de edificio ou obra que lhe pertença ou cuja conservação lhe incumba.

Pena - multa de 1 a $10: 000 \$ 000$.

$\S 10^{\circ}$ - Se o desastre se verificar e sofrer prejuizo o patrimonio alheio.

Pena - multa de 1 a $10: 000 \$ 000$.

§ 2. - - Se resultar do desastre lesão grave ou gravissima.

Pena - detenção por 3 meses a 1 ano e multa de 1 a10:000\$.

$\S 3 .^{\circ}$ - Se resultar do desastre a morte de alguem.

Pena - detenção por 1 a 3 anos e multa de 5 a 20:000\$000. 
Pr. 462 - Aquele que não tomar as providencias devidas para acautelar o público do perigo oriundo do estado de algum predio, do qual seja locatario ou proprietario será punido com multa.

Cons. Omissa.

Art. 249 - Subtrair, ocultar ou inutilizar, por ocasião de incendio, inundação, naufragio ou outra calamidade, aparelho, material ou meio destinado a combater o perigo ou a prestar serviço de salvamento ou socorro; ou de qualquer modo impedir ou dificultar serviço de tal natureza.

Pena - reclusão por 2 a 5 anos e multa de 1 a 10:000\$000.

$\S$ único - Se o crime fôr culposo.

Pena - detenção por 3 meses a 1 ano ou multa de 1 a 5:000\$, ou ambas cumulativamente.

Pr. Omisso.

Cons. Omissa.

Art. 250 - Fabricar, adquirir, alienar, emprestar ou ceder, por conta propria ou alheia, substancia ou engenho explosivo ou gaz tóxico ou inflamavel; ou fornecer instruções ou material para a sua fabricação; ou guardá-lo, transportá-lo ou transmiti-lo a terceiro; tudo quando saiba ou deva presumir o agente que se destina a fim criminoso.

Pena - reclusão por 1 a 5 anos e multa de 1 a 5:000\$000.

$\S 10^{\circ}$ - Fabricar, importar, ter em depósito, alienar ou expôr á venda, sem licença da autoridade ou sem as cautelas necessarias, substancia explosiva ou destinada á respectiva composição ou fabricação.

Pena - detenção por 15 dias a 6 meses ou multa de $200 \$$ a 2:000\$000.

$\S 2 .^{\circ}$ - Deixar de comunicar á autoridade a existencia, em poder do agente, de substancia tóxica inflamavel ou explosiva, de qualidade ou em quantidade não reclamadas pelo exercicio de pro- 
fissão ou pela exploração normal de propriedade; ou deixar de entregar tais substancias, quando por lei seja obrigado a faze-lo.

Pena - multa de 200\$000 a 2:000\$000.

Pr. - Será punido com prisão até 3 anos, quando em pena mais grave não incorrer, aquele que, sabendo ou devendo presumir que taes cousas se destinam a fim criminoso; 1) fabricar bomba de dinamite ou de outra substancia que nos seus efeitos se lhe equipare; 2) fabricar gazes tóxicos ou substancias inflamaveis; 3) fornecer a alguem ou, para fornecer-lhe, adquirir ou procurar adquirir as substancias necessarias á fabricação das cousas acima especificadas; 4) ensinar alguem a fabricá-las; 5) se prestar a guardá-las, transportá-las ou transmiti-las a terceiro; 463: Será punido com detenção até 1 mês, ou com multa e na reincidencia, com detenção por 1 a 2 meses e com multa aquele que... infringir as prescrições regulamentares no fabricar, manipular, remover, ou transportar substancias inflamaveis, explosivos ou corrosivos, ou os seus produtos, ou produtos quimicos susceptiveis de causar estragos..

Lei n. 38, de 35, art. 13: Fabricar, ter sob sua guarda, possuir, importar ou exportar, comprar ou vender, trocar, ceder ou emprestar por conta própria ou de outrem, transportar, sem licença da autoridade competente, substancias ou engenhos explosivos ou armas utilizaveis como de guerra ou como instrumento de destruição - 1 a 4 anos. § un. Independe de licença da autoridade policial, mas a esta deve ser comunicada sob pena de apreensão, a posse: a) de explosivos necessarios ao exercicio da profissão ou á exploração normal da propriedade; b) de arma necessaria á defesa ao domicilio do morador rural.

Art. 251 - Fabricar, importar, exportar, conservar em deposito ou vender, sem permissão da autoridade, munição ou arma, que não seja objeto de arte ou antiguidade.

Pena - detenção por 3 meses a 1 ano, ou multa de 1 a $5: 000 \$$, ou ambas cumulativamente.

§ único - Na pena de multa de 200\$000 a 2:000\$000 incorrerá aquele que:

I - tendo em seu poder arma ou munição, não fizer comunicação ou entrega á autoridade, quando a lei o determine;

II - fóra de sua casa ou dependencia, trouxer consigo arma ofensiva, s $\in$ m licença da autoridade ou sem motivo justo; 
III - permitir que a tragam consigo alienado, ou menor de 14 anos, ou pessoa inexperiente em manejá-la;

IV - omitir as cautelas necessarias para impedir que dela se apodere facilmente alguma das pessoas indicadas no inciso anterir.

Pr. 464 - Aquele que em tempo de paz, nos logares povoados ou imunes, por policiamento eficaz, ás incursões de bandidos e salteadores, detiver armas e munições, cuja posse, pela quantidade e qualidade, se não justifique com o fim exclusivo da caça, será punido com multa e confisco. 465: Aquele que, sem licença da autoridade, nem a exercendo, transitar pela via pública com armas ofensivas, de fogo, perfurantes ou cortantes, embora as dissimule ou oculte em objeto de uso necessario e comum, será punido com detenção até 20 dias, mais a multa e o confisco. 466: Não cometem a contravenção acima prevista aqueles que viajarem pelo interior do paiz com a conduta abonada por documentos ou pelo testemunho de homens bons, ou legitimamente conduzindo haveres, valores, ou quantias, cuja conservação ou guarda reclamen vigilancia armada. Não a cometerão tambem, quanto ás armas brancas, aqueles que as trouxerem durante os trabalhos de campo, ou conduzindo tropas e rebanhos, ou produtos da lavoura ou da industria, contanto que não entrem armados nas povoações onde tenham de demorar-se, nem as ostentem naquelas que atravessarem. 467: Aquele que, como mercador ambulante, vender armas será punido com multa. $\mathrm{Na}$ reincidencia, a pena será a de detenção por 1 a 3 meses e multa, podendo ser imposta tambem a interdição.

Cons. 376 - Estabelecer sem licença do Governo, fábrica de armas, ou polvora - perda para a Nação dos objétos apreendidos e multa de $200 \$$ a 500\$000. 377: Usar de armas ofensivas sem licença da autoridade policial - 15 a 60 dias. § un. - São isentos de pena: 1) os agentes ou autoridade publica em diligencia ou serviço; 2 ) os oficiaes e praças do exército, da armada e da guarda nacional, na conformidade dos seus regulamentos.

Art. 252 - Punir-se-á com multa de 100\$ a 1:000\$ aquele que, em logar habitado ou em suas adjacencias, ou em via publica, ou em direção a ela;

I - disparar arma de fogo;

II - sem licença da autoridade, queimar fogo de artificio ou causar deflagração perigosa.

III — soltar balão aceso. 
Pr. - 463 - Será punido com detenção até 1 mês, ou com multa, e na reineidencia com detenção por 1 a 2 meses e com multa aquele que: 1) disparar arma de fogo $\mathrm{em}$ logares frequentados ou na via publica... 2) soltar ao sabor do vento balōes acesos ou artefatos pirotécnicos que ainda não apagados, possam cair ao acaso, em logar incerto.

Cons. Omissa.

Art. 253 - Punir-se-á com multa de 100\$ a 2:000\$000 aquele que :

I - deixar de colocar sinal ou vedação na via pública, para prevenir os transeuntes de perigo resultante de obra que esteja executando;

II - apagar sinal luminoso ou destruir ou remover sinal de outra natureza ou vedação destinados ao objetivo constante do inciso anterior;

III - remover qualquer outro sinal destinado a serviço público;

IV - apagar aparelho de iluminação pública;

$\mathrm{V}$ - der aviso falso de incendio, crime ou acidente;

VI - deixar em liberdade ou não guardar com a devida cautela, ou confiar á guarda de pessôa inexperiente animal perigoso;

VII - abandonar em logar aberto animal de tiro, carga ou corrida, ou confiá-lo a pessôa inexperiente;

VIII - excitar ou irritar animal, de maneira a pôr em perigo a segurança publica;

IX - dirigir na via pública animal ou veículo de modo a pôr em perigo a segurança alheia;

$\mathrm{X}$ - dirigir veículo na via pública, ou em logar accessivel ao público, ou embarcação a motor em aguas públicas, ou aeronave, sem estar devidamente licenciado;

$X I$ - entregar-se fóra do campo de aviação a acrobacia aerea ou descer voluntariamente fóra dos logares destinados a esse fim; 
XII - deixar suspensa ou atirar ou deixar cair sobre a via pública ou logar de uso comum ou alheio, cousa capaz de sujar ou molestar alguem;

XIII - provocar, fóra dos casos pcrmitidos em lei, emissão de gaz, fumaça ou vapôr sasceptivel de produzir um dos resultados constantes do inciso anterior;

XIV - não exercer a vigilancia necessaria com relação a alienado perigoso, cuja guarda lhe incumba; ou deixar de avisar de sua fuga a autoridade.

Pr. 455 - Será punido com multa aquele que 1) detiver, sem permissão da autoridade, animaes selvagens perigosos, ou não trouxer devidamente preso aquele que esteja autorisado a deter; 2) não resguardar devidamente os transeuntes ou as pessôas que tenham o dever de lhe ir á casa, das investidas de algum cão de fila, ou não avisar a autoridade de que esse cão the pertença, se manifestaram sintomas de hidrofobia. O juiz poderá ordenar que o animal seja abatido, e, no caso de perigo iminente, poderá abatê-lo a policia, ou qualquer pessôa do povo. 456: Aquele que conduzir veículo na via pública ou em logar de transito público, sem estar devidamente habilitado ou licenciado, ou não exibir, se a autoridade, ou um seu agente, o reclamar, a prova da habilitação ou da licença, será punido com multa. A multa será aumentada de $1 / 3$ se o veículo fôr automovel ou motociclo e da metade se o contraventor já havia sido inhabilitado para conduzi-lo ou por acidente ou desastre na via pública, desta faculdade havia sido privado. 457: Será punido com detenção até 1 mês e com multa aquele que: 1) em logares habitados ou onde o povo se aglomere, imprimir velocidade excessiva a qualquer veícklo, especialmente a automoveis; 2) sem estar devidamente habilitado, nem licenciado, dirigir aeronaves; 3) fóra da zona destinada a exercicios, se entregar a acrobacias, que aumentem os riscos da viação aerea. Na reincidencia a multar será dobrad a e na reiteração o veículo ou aparelho será confiscado. 458: Aquele não exercer a devida vigilancia sobre alienado perigoso... ou não avisar á autoridade de terem eles fugido, será punido com detenção até 1 mês ou com multa. 460: Será punido com multa e na reincidencia com detenção até 30 dias e com multa aquele que: 1) tendo o dever de fazê-lo, não prevenir os transeuntes, por meio de indicações e sinaes adequados, do perigo que lhes possa advir de construções, demoliçōes e obras, ou objétos depositados na vía pública; 2) retirar, remover, apagar ou inutilizar qualquer indicação ou sinal com que se previnam as pessôas contra perigo para o transito público. 461: Aquele que projetar, ou deixar cair sobre a via publica, ou logares onde se transitar, 
cousas que possam ofender, sujar ou molestar as pessôas, ou que próvocar, sem legalmente poder fazê-lo, emissões de gaz, vapores ou fumo, capazes de produzirem aqueles resultados, será punido com multa e na reincidencia com detenção até 15 dias e com multa. § um. Nas mesmas penas incorrerá aquele que sem as devidas cautelas, colocar ou suspender suas casas objetos que, caindo, possam ofender, sujar ou molestar os transeuntes.

Cons. 378 - Conservar soltos ou guardados sem cautela animaes bravios, perigosos ou suspeitos de hidrofobia; deixar, neste ultimo caso, de dar aviso á autoridade publica, para providenciar como o caso exigir; deixar vagar loucos confiados á sua guarda ou, quando evadidos de seu poder, não avisar a autoridade competente para os fazer recolher; receber em casa particular, sem aviso prévio á autoridade ou sem autorisação legal, pessôas afetadas de alienação mental... destruir ou remover os sinaes colocados na via pública para prevenir algum sinistro ou advertir do perigo os transeuntes; dar aviso falso de incendio - multa de $50 \$$ a $1000 \$ 000$.

\section{TITULO VI}

\section{Dos crimes contra a fé pública}

\section{Capitulo I}

\section{Dos crimes referentes á moeda}

Art. 254 - Falsificar moeda, nacional ou estrangeira, que tenha curso legal ou comercial dentro ou fóra do paiz:

I - Fabricando, sem a devida autorização, moeda com o mesmo peso e valôr intrinseco da genuina;

Pena - reclusão por 3 a 9 anos e multa de 1 a 5:000\$000.

II - Fabricando-a com materia, peso ou valor intrinseco diferentes da genuina.

Pena - reclusão por 5 a 15 anos e multa de 5 a $15: 000 \$ 000$.

III - Diminuindo o peso de moeda genuina, ou aumentandolhe, mediante qualquer artificio, o valor aparente.

Pena - reclusão por 5 a 15 anos e multa de 5 a $15: 000 \$ 000$. 
Pr. 297 - Será punido com prisão por 3 a 12 anos e com multa aquele que tratando-se de moeda de ouro ou prata, com curso legal ou comercial dentro ou fóra do paiz: 1) sem estar legalmente autorizado, a fabricar; 2) por qualquer modo alterar a moeda genuina, dando-lhe valor aparente maior do que na realidade tenha... § un. Este artigo é aplicavel ás moedas doutro metal que não o ouro e a prata, caso em que a pena será a de prisão até 3 anos, mais a multa.

Cons. 239 - Constitue crime de moeda falsa: a) fabricar, sem autoridade legítima, moeda de prata ou de ouro, nacional ou estrangeira, que tenha curso legal ou comercial dentro ou fóra do paiz, com o mesmo peso e valor intrinseco da verdadeira -4 a 8 anos... Se a moeda fôr fabricada com materia diversa, peso ou valor intrinseco diferente da verdadeira - 6 a 12 anos... b) diminuir o peso da moeda verdadeira ou aumentar-lhe o valor -3 a 6 anos. 240: Nos casos previstos nas letras a e b e se fôr a moeda de qualquer outro metal que não ouro ou prata... reduzido de $1 / 3$ o tempo da prisão.

Art. 255 - Falsificar, fabricando-o ou adulterando-o, papel de credito público, que, emitido pela União ou por instituto devidamente autorizado, tenha curso legal ou comercial no paiz; ou papel de crédito que represente moeda estrangeira.

Pena - reclusão por 5 a 15 anos e multa de 5 a 15:000\$000.

Pr. 298 - Aquele que falsificar papel de credito publico, revestido do curso legal da moeda ou que nas repartições do Estado, tiver o mesmo poder liberativo, quer de novo inteiramente 0 faça, quer em parte sómente o altere, será punido com prisão por 3 a 12 anos e com multa. $\S 10^{\circ}$ - Para os efeitos penaes considera-se papel de crédito público não só o que emitido pela União, ou pelos bancos legalmente autorizados, tiver o poder liberatorio de moeda, como tambem o que representax moeda estrangeira.

Cons. 239 - . falsificar, fabricando ou alterando, qualquer papel de crédito público, que se receba nas repartições públicas como moeda. - 4 a 8 anos. Para os efeitos da lei penal considera-se papel de crédito público o que tiver curso legal, como moeda, ou fôr emitido pelo Governo da União ou por estabelecimentos bancarios legalmente autorisados, bem assim o que representar moeda estrangeira.

Art. 255 - Punir-se-á com reclusão por 3 a 9 anos e multa de 1 a 5:000\$000 aquele que:

I - formar cédula, nota ou bilhete com fragmentos de outros, genuinos; 
II - suprimir em nota, cédula ou bilhete, recolhidos, o carimbo ou sínal indicativo da inutilização, ou restitui-los á circulação fraudulentamente.

§ único - Aumentar-se-á a pena se o crime fôr cometido por funcionario que trabalhe na repartição, onde as notas, cédulas ou bilhetes estiverem recolbidos, ou que, em razão do cargo, nela tenha facil ingresso.

Pr. 299: - Será punido com prisão por 2 a 6 anos e com multa aquele que: 1) formar cedulas ou notas do governo da União, cedulas ou bilhetes do Thesouro, Caixas ou Institutos Federaes, ou de Bancos legalmente autorizados a emiti-los com fragmentos de outras notas, cedulas ou bilhetes verdadeiros, de modo a poder faze-los passar como genuinos; 2) suprimir o carimbo com que se tiverem inutilizado as cédulas, notas e bilhetes recolhidos, ou que os restituir fraudulentamente á circulação; 3) subtrair ao carimbo cedulas, notas e bilhetes, que por ele devessem ser inutilizados para a circulação. § un. Considerar-se-á como agravante e circunstancia de ser o inculpado funcionario da repartição em que se achavam as cédulas, notas ou bilhetes de que neste artigo se trata, ou de nela ter facil ingresso em razão do seu cargo.

Cons. 239: d) ... formar cédulas ou notas do Governo, cédulas ou bilhetes do Tesouro Federal da Caixa de Conversão ou de Bancos, com fragmentos de outras notas e cédulas ou bilhetes verdadeiros; suprimir ou fazer desaparecer, por qualquer meio, os carimbos com que forem assinaladas as notas, cédulas ou bilhetes retirados da circulação. 241: Se os crimes previstos na letra $d$.. forem cometidos por funcionarios da Repartição em que se acham recolhidas as notas, cédulas ou bilhetes 6 a 12 anos, perda do emprego, inhabilitação por 12 a 20 anos.

Art. 257 - Punir-se-á com reclusão por 1 a 15 anos o funcionario público ou diretor, gerente, ou fiscal de banco de emissão que fabricar, emitir ou autorizar a fabricação ou emissão:

I - de moeda com titulo ou peso inferiores aos determinados em lei ;

II - de papel de crédito publico em quantidade superior á autorizada.

Pr. Omisso. 
Cons. 244 - Incorrerão... 1 a 4 anos.. os diretores e gerentes dos bancos de emissão, pelo excesso da emissão de bilhetes além dos limites determinados nas leis respetivas, e bem assim os fiscaes do Governo, que se mostrarem em tal falta o não os tenham denunciados oportunamente.

Art. 258 - Fabricar, adquirir, alienar, emprestar ou ter sob sua guarda, por conta própria ou de terceiro, instrumental ou material destinados especialmente á fabricação ou alteração de moeda ou papel de crédito público, sabendo ou devendo presumir a sua destinação criminosa.

Pena - reclusão por 2 a 6 anos.

Pr. 301 - Aquele que fabricar, explorar, possuir ou guardar maquinismos, aparelhos e instrumentos especialmente apropriados á fabricação, falsificação ou alteração da moeda nacional ou estrangeira, de curso legal ou comercial, dentro ou fóra do paiz, sobendo ou devendo presumir que a sua destinação é criminosa, será punido com prisão por 1 a 5 anos.

Cons. 242: d:... fabricar, explorar, possuir ou ter sob sua guarda maquinismos ou objetos exclusivamente á fabricação ou alteração da moeda nacional ou estrangeira, de curso legal ou comercial, dentro ou fóra do paiz - 2 a 6 anos.

Art. 259 - Adquirir, alienar, emprestar ou ter sob sua guarda, por conta propria ou alheia, ou introduzir de qualquer maneira na circulação moeda falsa ou papel de crédito público falsificado, nos termos dos arts. 261, 262 e 263.

Pena - as dos arts. 261, 262 e 263, conforme a hipótese.

$\S$ único - Restituir á circulação, depois de conhecida a falsidade, moeda ou papel de crédito público, recebidos de bôa fé.

Pena - detenção por 6 meses a 2 anos ou multa de 1 a $10: 000 \$ 000$; é, na reincidencia especifica ou reiterada, ambas cumulativamente.

Pr. 300 - Aquele que, depois de conhecida que são falsos, restituir á circulação, moeda, papel moeda ou valores equivalentes, que de bôa fé tivesse recebido como verdadeiros, será punido com detenção ou com multa, e na reincidencia com prisão até 3 anos e com multa. 
Cons. 242, c - Restituir á circulação moeda falsa, recebida como verdadeira, depois de conhecida a falsidade ou tendo razăo para conboce-la - multa de 5 a 20 vezes o valor da moeda... No caso de relncidencia 1 a 3 meses e multa de 10 a 30 vezes.

Art. 260 - Emitir, sem autorisação legal, nota, bilhete, ficha, vale ou titulo, que contenha promessa de pagamento em dinheiro ao portador ou com o nome deste em branco.

Pena - detenção por 1 a 6 meses, ou multa de 1 a $20: 000$.

$\S 10^{\circ}$ - Receber ou utilizar como moeda título dessa natureza, ou apólice ou títulos ao portador emitido por Estado ou Manicipio.

Pena - multa de 500 a $5: 000 \$$.

$\S 20^{\circ}$ - Não se compreendem no presente dispositivo as letras de cambio ao portador ou endossadas em branco, os recibos ou mandados ao portador, em virtude de conta corrente bancaria, saldo exigivel de conta corrente contratual ou soma proveniente de abertura de crédito.

Pr. 483 - Aquele que, não estando por lei autorizado, emitir notas, bilhetes, fichas, valores, papel ou título, que contenham promessa de pagamento em dinheiro ao portador ou com o nome deste em branco, serí punido com detenção por 1 a 3 meses e com multa, sómente com esta sendo dores das sociedades por emitirem títulos de obrigação (debenturen) 20 portador, sem os requisitos no decr. 177-A, de 93. \& $2 .^{\circ} \mathrm{O}$ disposto neste art. não compreende as letras de cambio ao portador, as endossadas em branco, as notas promissorias assim endossadas, e recibor mandados a portador em virtude de contas correntes bancarias, saldo exigivel de contas-correntes contratuaes, ou soma proveniente de abertura de cródito. 8 3. 0 O disposto neste art. tambem não compreendo as apólices e titulos ao portador que os Estados ou Municipios emitam.

Cons. 243 - Não poderão ser recebidos como moeda, ou nesta qualidade circular no paiz, quaesquer titulos de crédito ao portador, ou com - nome deste em branco, que forem emitidos pelos governos dos Estandos ou dos Municipios, sejam taes titulos apolices ou outras de denominações diferentes. No caso de transgressåo.. os Individuos que como moeda empregarem ou os receberem, em troca de objetos, valoree ou serviços de qualquer especie, ficam sujeitos án penas de prisán celular por 2 a 4 anos e perda dos mesmos titulon. 404: conforme o art. 483 do pr. 
Art. 261 - Distribuir, como meio de propaganda, objeto suscetivel de confusão com moeda ou titulo de credito público.

Pena - multa de 100\$ a 1:000\$000.

Pr. 439 - Aquele que, como meio de propaganda ou preconício de qualquer processo, produto ou marca, usar de emblemas, desenhos impressos ou gravuras que possam ser confundidos com a moeda por um homem ignaro e simples, será punido com multa e os objetos suscetiveis de confusão confiscados.

\section{Capitulo II}

Dos crimes referentes a titulos e papeis de emissão privativa do poder público e marcas oficiais

Art. 262 - Falsificar, fabricando-o ou adulterando-os :

I - titulo ou coupon da dívida pública, federal, estadual ou municipal;

II - bilhete ou letra do Tesouro da União, do Estado ou de Municipio;

III - vale postal;

IV - cautela de Monte de Socorro oficial ou caderneta de Caira Economica mantida por entidade de direito público;

$\nabla$ - talão, recibo, guia, alvará ou outro documento referente á arrecadação de rendas públicas ou a depósito ou fiança, por que - poder público seja responsavel;

Pena - reclusão por 3 a 12 anos e multa de 3 a 12:000\$.

§ unico - Incorrerá na mesma pena aquele que:

I - negociar ou usar de qualquer dos papeis enumerados neste dispositivo, sabendo ser falso;

II - adquirir, alienar ou tiver sob sua guarda, conhecendolhe a falsidade, qualquer dos papeis mencionados nos ns. I, II, III e IV deste dispositivo. 
Pr. 320 - Será punido com prisăo por 2 a 6 anos e com multa aquele que, fabricando ou alterando, falsificar: 1) papeis de crédito público ou titulos da divida páblica, sem o curso permanente e legal da moeda: 2) bilhetes e letras do Tesouro; 8) coupons da divida pública. $\S$ um. As mesmas penas serão aplicadas ao que fizer uso de papel ou título das especies acima indicadas, sabendo serem falsos. No caso do culpa aplicar-se-á a multa. 322: Aquele que, fabricando ou siterando, falsificar vales postaes, ou cautelas do Monte Socorro, ou dele fizer uso, será punido com prisāo por 1 a 4 anos e com multa. A pena seŕ́ de multa no caso de culpa. 323: Aquele que, labricando ou alterando falsificar letras, recibos ou quitaçōes, guies, alvarás e outros documentos concernentes á arrecadaçảo da renda pública, ou a fiança e depositos pelos quaes o Estado responda, assim the causando ou podendo causar prejuizo, será punido com prisāo por 1 a 5 anos e com multa. \& un.. Incorrerá nas mesmas penas aquele que os vender a público, sabcendo serem falsos, ou terem sido falsificados, e somente com multa no caso de culpa. 325: Na aplicação dos artigos deste capitulo entender-se-á que, na palavra Estado, se compreendem não só a Uniăo, como tambem os Estados, Municipios e Prefeituras.

Cons. 245 - Falsificar, fabricando ou alterando, papeis de credito ou titulos da dívida publica, bilhetes e letras do Governo da Uniño, dos Estados, Municipalidades ou Prefeituras, cautelas do Monte do Socorro, e cadernetas da Caixa Economica; usar desses papeis, bilhetes, letras, cautelas e cadernetas, sabendo que são falsas -4 a 8 anos, multa de 5 a 20\%... 248: Falsificar, fabricando ou alterando, talöes, recibos, quitações, guias, alvarás e outros documentos destinados á arrecadacío da renda da Uniāo, dos Estados, Municipios e Prefeituras ou relativo ás fianças e aos depositos de dinheiros de particulares, orfāos, ausentes e defuntos; usar desses papeis, assim falsificados - 4 a 5 anos e multa de 5 a $20 \%$.

Art. 263 - Falsificar, fabricando-o ou adulterando-o, papel selado, selo adesivo, estampilha ou outro papel destinado á percepção de imposto ou taxa federal, estadual ou municipal; ou ne. gociar, ter sob sua guarda ou introduzir na circulação algum deles, conhecendo-lhe a falsidade.

Pena - reclusão por 3 a 12 anos e multa de 3 a $12: 000 \% 000$.

$\S 10^{\circ}$ - Panir-se-́́ com reclusăo por 2 a 6 anos e multa de 3 a 9:000\$000 aquele que falsificar, negociar ou tiver sob sua guarda instrumental ou material destlaados á fabricação ou alteração de quaesquer dos papeis mencionados neste dispositivo, anben. do ou devendo presumir a sua destinação oriminosa. 
$\S 20^{\circ}$ - Punir-se-́́ com reclusão por 5 a 10 anos o funcionario que emitir qualquer dos mencionados papeis em quantidade superior á autoorizada.

§ $3^{\circ}$ - Punir-se-á com detenção por 6 mezes a 2 anos ou multa de 1:000\$ a 10:000\$000, ou, no caso de reincidencia, ambas cumulativamente, aquele que:

I - usar ou restituir á circulação, conhecendo-lhe a falsidade, qualquer dos referidos papeis, recebidos de bôa fé;

II - suprimir ou fizer desaparecer, por qualquer meio, de algum dos mencionados papeis, quando legitimo, o carimbo ou sinal com que tenha sido obliterado;

III - utilizar papel de qualquer das especies enumeradas, que seja legitimo, mas que já tenha sido utilizado anteriormente.

Pr. 321 - Aquele que fabricando ou alterando, falsificar selos adesivos ou estampilhas ou qualquer outro valor de emissão legal, com que - particular se quite de imposto ou taxa, será punido com prisão até 3 anos e com multa. § um. As mesmas penas serão aplicadas, mas no caso de culpa sómente de multa, áquele que emitir valores das especies acima indicadas, deles fizer uso ou os adquirir ou guardar para lançar na circulação.

Cons. 247 - Falsificar, fabricando ou alterando, selos adesivos, estampilhas, vales postaes, coupons da divida pública da União, dos Estados, das Municipalidades e Prefeituras; emiti-los sem autorização legal quando verdadeiros; suprimir ou fazer desaparecer, por qualquer meio, os carimbos ou sinal com que tenham sido inutilisados; emitir ou introduzir dolosamente na circulação, importar ou exportar, comprar ou vender, trocar, ceder ou emprestar, por conta própria ou de outrem, os sobreditos selos, estampilhas, vales e coupons falsificados pelos modos referidos no principio deste artigo, conhecida a falsificação; usar dolosamente dos selos, estampilhas, vales e coupons assim falsificados 2 a 6 anos, multa de 5 a $20 \%-250 \S$ un.: Possuir ou ter sob sua guarda, para fim criminoso, moeda falsa, selos, estanıpilhas ou quaesquer dos titulos ou papeis falsificados na forma deste e dos artigos anteriores - penas as mesmas dos referidos arts.. reduzidas a 1/3.

Art. 264 - Punir-se-á com reclusão por 2 a 6 anos e multa de 1 a 10:000\$000 aquele que, para atribuir caráter publico a um documento : 
I - falsificar, fabricando ou alterando, o sêlo publico destinado a autenticar atos oficiais da União, de Estado ou de Municipio;

II - falsificar, fabricando ou alterando, o selo ou sinal atribuido por lei a uma entidade ou autoridade pública, ou o sinal público de tabelião;

III - usar cientemente de selo ou sinal, a que se refere esta disposição, falsificado por outrem;

IV - tendo conseguido sinal ou selo verdadeiro, utiliza-lo em prejuizo de outrem ou em proveito próprio ou alheio.

$\S 10^{\circ}$ - Aumentar-se-á a pena se o crime fôr cometido por funcionario público.

$\S 20^{\circ}$ - Diminuir-se-á a pena se o selo falsificado ou usado cientemente fôr de nação ou autoridade estrangeira.

Pr. 305 - Será punido com prisão até 3 anos e com multa aquele que para fazer passar como público qualquer documento: 1) falsificar, fabricando ou alterando o selo público da União, dos Estados, Municipios e Prefeituras; 2) falsificar, fabricando ou alterando, o selo ou sinal público por lei atribuidos a qualquer instituto oficial ou autoridade, ou - sinal público dos tabeliães de notas; 3) cientemente fizer uso de selo ou sinal publico por outro falsificado. O maximo da prisão será de 5 anos, quando o crime fôr cometido por funcionario público dos tabeliães de notas; 3) cientemente fizer uso de selo ou sinal publico por outro falsificado. 0 maximo da prisão será de 5 anos, quando o crime fôr cometido por funcionario público.

Cons. 247 - Falsificar, fabricando ou alterando, o selo público da União, dos Estados, nas Municipalidades ou Prefeituras destinado a autenticar ou legalizar os atos oficiaes -2 a 4 anos.

Art. 265 - Falsificar, fabricando ou alterando, marca ou sinal empregado pelo poder publico no contraste de metal precioșo ou na fiscalização aduaneira; ou usar cientemente de marca ou sinal dessa natureza, falsificado por outrem.

Pena - reclusão por 2 a 6 anos e multa de 5 a $15: 000 \$$.

$\S 10^{\circ}$ - Se a marca ou sinal fabricado, alterado ou usado cientemente como falso, fôr dos empregados pela autoridade pública na aferição de pesos e medidas, ou fiscalização sanitaria, ou 
para autenticar ou encerrar determinados objetos, ou para comprovar o cumprimento de formalidade legal.

Pena - reclusão ou detenção por 1 a 3 anos e multa de 1 a $10: 000 \$ 000$.

$\S 2 .^{\circ}-\mathrm{Na}$ mesma pena incorrerá quem, em estabelecimento comercial ou industrial ou em logar aberto ao público, tiver em seu poder, medida ou peso viciado, ou não aferido, ou com a marca de aferição falsificada ou alterada.

Pr. - Aquele que fabricando ou alterando, falsificar: 1) as marcas de que use o Estado para o contraste do ouro e da prata trabalhados ou na fiscalisação aduaneira; 2) as de que use na fiscalisação sanitaria ou higienica; 3) as que, apostas pela autoridade sobre algum objéto, servirem para encerrá-lo, identificá-lo, licenciá-lo ou isentá-lo de formalidades e onus, ou que garantirem o resultado do exame a que tiver sido o mesmo submetido, será punido no hipotese do n. 1 com prisão por 2 a 6 anos; nas demais com detenção até 1 ano, e, na reincidencia, com prisão até 2 anos. Em todos os casos a multa é cumulavel. § un. Incorrerá nas penas acima cominadas aquele que cientemente, usar de marcas falsificadas, e, em multa, no caso de culpa. 303: Será punido com prisão até 3 anos, e com multa aquele que, em peso, balanças, medidas e quaesquer instrumentos oficiaes de mensuração, capacidade ou gravidade: 1) fizer puntura, sinal ou cunho falsos, ou alterar os verdadeiros; 2) modificar os proprios objetos. acima referidos, de modo a poder lesar terceiros com quem venha a tratar. § un. Incorrerá na smesmas penas aquele que, cientemente, usar dos objetos referidos neste art., e, no caso de culpa incorrerá em multa.

Cons. Omissa.

\section{Capitulo III}

\section{Da falsidade documental}

Art. 266 - Falsificar documento público, fabricando-o no todo ou em parte, ou alterando-o quando verdadeiro.

Pena - reclusão por 2 a 6 anos e multa de 1 a 10:000\$000.

$\S 10^{\circ}$ - Se o crime fôr cometido, com abuso do cargo, por funcionario público. 
Pena - reclusão por 3 a 7 anos e multa de 2 a $15: 000 \$ 000$.

$\S 20^{\circ}$ - Aumentar-se-á a pena cominada no $\S 10^{\circ}$ se o funcionario público houver cometido o crime mediante paga ou promessa de recompensa.

$\S 3 .^{\circ}$ - Punir-se-á com reclusão por 1 a 5 anos e multa de $500 \$$ a 5:000\$, quem, não tendo concorrido para a falsificação, fizer uso cientemente de documento público falsificado.

Pr. 306 - Aquele que com o fim de prejudicar terceiro, ou de obter, para si ou para outrem, vantagem ilícita, fabricar no todo ou em parte documento publico falso, ou alterar documento público verdadeiro, será punido com prisão por 1 a 4 anos e com multa. A prisão será de 2 a 6 anos, quando o crime fôr cometido por funcionario público. § unico. Este artigo aplicar-se-á desde que o documento falsificado ou alterado puder causar prejuizo e nas suas penas incorrerá quem cientemente do mesmo tïzer uso.

Cons. $252-0$ funcionario ou oficial publico que no exercicio de suas funções, falsificar, fabricando ou alterando no todo ou em parte, escrituras, livros, documentos de que possa resultar prejuizo público ou particular.. 2 a 6 anos e multa de 5 a $20 \%$. $\$ 3 .^{\circ}$ Com as penas estabelecidas neste art. menos a terça parte, será punido aquele que, não sendo funcionario ou oficial público, cometer qualquer falsidade pelos meios acima previstos.

Art. 267 - Punir-se-á com reclusão por 1 a 6 anos, e multa de 1 a 10:000\$000 o funcionario público que:

I - expedir cópia legalizada de documento público ou particular inexistente ou expedi-la em desacordo com o original;

II - reconhecer como verdadeira firma que não o seja;

III - omitir ou alterar substancialmente declaração que lhe seja feita e deva constar do documento público; ou atestar haver praticado ou presenciado ato que realmente não praticou ou presenciou, ou ter-lhe sido feita declaração que de fato não se lhe fez;

IV - lançar ou fizer lançar, sem autorização do sinatário, ato público, gerador de efeitos juridicos, em papel assinado, que, contendo espaço em branco, tenha vindo ao poder do agente, em razão do oficio, para fim diverso.

$\S 10^{\circ}$ - Aumentar-se-á a pena se o crime fôr cometido mediante paga ou promessa de recompensa. 
$\S 20^{\circ}-$ Punir-se-á com reclusão por 1 a 5 anos e multa de 1 a 5:000\$000 aquele que cientemente usar do documento, não tendo concorrido para a falsidade.

Pr. 308 - Será punido com prisão até 4 anos o funcionário público que: 1) simular cópia autêntica de documento público ou privado inexistente e fornecel-a a alguem devidamente legalizada; 2) fornecer a alguem cópia autêntica diversa, no todo ou em ponto essencial, do documento originario, publico ou privado. A pena será a de prisão até 2 anos, para o particular que cientemente fizer uso de cópia compreendida nos nos. 1 e 2 deste artigo. 309: Será punido com prisão até 4 anos e com detenção até 6 meses ou multa, no caso de culpa, o funcionario público que, no exercicio de suas funções, recebendo ou fazendo algum documento: 1) falsamente atestar houver praticado o ato ou preenchido a formalidade, sem os quaes não teria ele validade; 2) atestar como reaes declarações falsas, ou omitir a sverdadeiras que lhe cumprisse declarar; 3) atestar como passados em sua presença fatos a que não tiver assistido, ou como reaes fatos imaginarios, quando da existencia deles depender a validade do ato juridico ou da obrigação; 4) substancialmente desfigurar os fatos verdadeiros que atestar; 5) por conhecimento pessoal reconhecer firmas falsas como verdadeiras. Aplicar-se-á sómente a multa quando não resultar prejuizo do ato culposo, ou fôr ele insignificante, ou tiver reparado. 310: 0 funcionario público que, por dever do oficio ou autorização do interessado, tendo de encher papel assinado em branco, escrever ou fizer escrever cousa diversa da que devesse ser escrita, ou lhe preencher os claros com dizeres diversos dos que devessem ser lançados, ou que estivesse autorizado a lançar, será punido com prisão até 5 anos, quando resultarem do ato consequencias graves. Poderá o Juiz atenuar livremente a pena; quanddo, circunstancias especiaes favorecendo o inculpado, o prejuizo tiver sido reparado, ou fôr insignificante.

Art. 268 - Dar funcionario público, ou pessôa legalmente autorizada a expedir documento de tal natureza, atestado ou certificado, em que haja afirmação falsa de bom procedimento, ou de pobreza, ou de outra circunstancia que habilite alguem a obter cargo ou emprego público, isenção de onus ou serviço, ou vantagem de qualquer especie.

Pena - multa de 200\$ a 1:000\$000.

$\S 10^{\circ}$ - Fabricar, no todo ou em parte, certificado ou atestado falso dessa natureza, ou alterá-lo, quando verdadeiro. 
Pena - detenção por 3 meses a 1 ano e multa de $200 \$$ a 1:000\$000.

$\S 2 .^{\circ}-$ Fazer uso cientemente de certificado ou atestado falso ou alterado, sem ter concorrido para a falsificação.

Pena - detenção por 1 a 3 meses, ou multa de $100 \$$ a $500 \$$, ou ambas cumulativamente.

Pr. 307 - Será punido com prisão até 3 anos e com multa aquele que, fabricando ou alterando, falsificar.. 1) certidões, certificados, atestados e autorizações de caráter administrativo, ou deles falsamente fizer constar como cumpridas condições essenciaes á sua validade; 2) sem ter falsificado ou concorrido para que se falsificasse qualquer dos referidos documentos, dele cientemente fizer uso. A prisão será de 4 anos, quando o crime fôr cometido por funcionario público.

Cons. Omissa.

Art. 269 - Dar médico atestado falso, destinado a fazer fé perante autoridade ou funcionario público.

Pena - multa de 200\$ a 1:000\$000.

$\S 10^{\circ}$ - Se, em virtude do atestado falso, fôr internada em manicômio pessôa que não o deva ser.

Pena - detenção por 3 meses a 2 anos ou multa de 1:000\$ a $10: 000 \$ 000$.

$\S 20^{\circ}$ - Se qualquer desses crimes fôr cometido mediante paga ou promessa de recompensa, aumentar-se-á a pena no caso do principio do artigo, e as penas serão aumentadas e cumuladas no caso do $\S 10^{\circ}$.

$\S 3 .^{\circ}$ - Falsificar, fabricando-o ou alterando-0, atestado médico.

Pena - no caso do principio do artigo, detenção por 3 meses a 1 ano ou multa de 1 a $3: 000 \$ 000$; e no caso do $\S 1 .^{\circ}$, reclusão por 1 a 3 anos e multa de 2:000\$ a 20:000\$000; penas que serão aumentadas, verificada a hipótese do $\S 2 .{ }^{\circ}$.

§ 4..$^{\circ}$ - Ás mesmas penas, com a redução de um terço, ficará sujeito aquele que, não tendo concorrido para a falsidade, usar cientemente do atestado falso. 
Pro. Omisso.

Cons. 256 - Dar, por favor, o médico atestado falso destinado a fazer fé perante a autoridade - multa de $200 \$$ a $500 \$$. 1) Se o crime fôr cometido por paga ou esperança de alguma recompensa - $200 \$$ a 1:000\$000. 2) Se por efeito do atestado falso alguem fôr admitido ou retido em uma casa de alienados ou sofrer qualquer prejuizo grave 8 mezes a 2 anos. 3) Se o crime previsto em o art. antecedente fôr cometido com a circumstancia mencionada em o art. I deste artigo 1 a 3 anos. 4) Falsificar um atestado para qualquer dos fins declarado nos artigos anteriores -6 meses a 1 ano $-\S$ um. Ás penas respetivas deste artigo fica sujeito tambem aquele que fizer uso de atestado falso.

Art. 270 - Afirmar falsamente a funcionario encarregado de lavrar documento público um fato que esse documento se destine a provar; ou a identidade, estado, ou outra qualidade pessoal, própria ou alheia;

Pena - detenção por 3 meses a 2 anos, ou multa de 1 a $5: 000 \$ 000$, ou ambas cumulativamente.

$\S 10^{\circ}-$ Aumentar-se-á a pena :

I - quando se tratar de ato do registro civil;

II - quando a falsa declaração relativa á propria identidade fôr prestada por acusado perante autoridade judiciaria, dando motivo ao registro da sentença condenatoria sob falso nome.

$\S 2 .^{\circ}$ - Diminuir-se-á a pena, quando da falsa afirmação, não compreendida nos casos do $\S 1 .^{\circ}$, nenhum dano possa resultar.

Pr. 311 - Aquele que em documento público destinado a provar algum fato, falsamente o afirmar ou atestar ao funcionario que tiver de escreve-lo ou subscrevê-lo, será punido com detenção até 6 meses. Nenhuma pena se aplicará quando da afirmação ou atestação falsa não puder resultar lucro ou proveito para alguem ou prejuizo de terceiro. Aplicar-se-á somente a multa quando, com a declaração falsa de filiação legitima, não se tiver vesado ao prejuizo patrimonial de terceiro, mas o fato será comunicado á autoridade competente para retificar o assentamento.

Cons. 253 - Afirmar falsamente ao funcionario ou oficial ou em qualquer documento particular a propria identidade ou estado, atestar as de outra pessoa, de modo que possa resultar prejuizo público ou particular - 1 a4 anos e 5 a $20 \%$. 
Art. 271 - Para os efeitos dos dispositivos precedentes, considera-se funcionario público todo aquele que imprimir cunho oficial a documento, lavrando-o, subscrevendo-o ou visando-o.

Pr. 319 - Considerar-se-á ... como funcionario público todo aquele que escrevendo, subscrevendo ou firmando qualquer documento, ou lhe apondo o seu "visto", o revestir de fé publica ou lhe der cunho oficial.

Cons. 254 - Para aplicação das disposições do art. antecedente عão equiparados aos funcionarios públicos todos aqueles que são autorizados a redigir ou subscrever escritos ou papeis, aos quaes a lei atribuia fé publica.

Art. 272 - Falsificar, fabricando-os no todo ou em parte, ou alterando-os, quando verdadeiros, testamento, codicilo, qualquer titulo ao portador ou transmissivel por endosso, não compreendidos em outro dispositivo deste código:

Pena - reclusão por 2 a 6 anos e multa de 1 a $10: 000 \$$.

$\S 10^{\circ}$ - Se o documento particular não fôr dos mencionados no principio deste artigo e nos $\S \S$ seguintes.

Pena - reclusão por 1 a 5 anos e multa de 500\$ a $5: 000 \$$.

$\S 2 .^{\circ}$ - Se fôr passe ou bilhete de estrada de ferro ou outra empresa de transportes públicos.

Pena - reclusão por 1 a 3 anos e multa de 500\$ a 3:000\$.

$\S 3 .^{\circ}$ - Se fôr receita médica, indispensavel á aquisição de determinada substancia.

Pena - detenção por 3 meses a 2 anos e multa de 500\$ a 2:000\$000, quando o fato não constituir crime previsto com pena mais grave.

§ $4^{\circ}$ - Se fôr telegrama, fabricado no todo ou em parte, ou alterado, quando verdadeiro, ou expedido em nome alheio, sem a devida autorização.

Pena - detenção por 1 mês a 1 ano ou multa de $200 \$$ a $1: 000 \$ 000$.

§5. - Punir-se-á com reclusão por 1 a 4 anos e multa de $500 \$$ a 5:000\$000 aquele que, não tendo concorrido para a falsidade, fizer uso de documento particular falsificado, nos termos do principio deste artigo e seu $\S 1 . \%$ 


\section{§6.0 - Punir-se-á :}

I - com reclusão por 1 a 3 anos e multa de $500 \$$ a $3: 000 \$$, aquele que suprimir em passe ou bilhete de estrada de ferro ou de outra empresa de transportes públicos sinal indicativo de sua utilisaęão anterior, afim de utiliza-lo novamente; ou cientemente adquirir, alienar, tiver em depósito ou utilizar passe ou bilhete falsificado por outrem;

II - com detenção por 1 a 6 meses ou multa de $200 \$$ a $2: 000 \$ 000$, aquele que, tendo recebido de bôa fé, passe ou bilhete falso de empresa de transportes, dele fizer uso, depois de ciente da falsidade.

$\S 60^{\circ}$ - Punir-se-á com detenção por 1 mês a 1 ano ou multa de 200\$ a 1:000\$000, se em outra mais grave não incorrer, aquele que cientemente fizer uso de receita médica falsa.

Pr. 312 - Será punido com prisão, até 5 anos aquele que com o fim de causar a alguem prejuizo patrimonial, social ou moral, imediato ou remoto ou de obter para si ou para outrem vantagem da mesma natureza: 1) falsamente fizer titulos pignoraticios, ou, no todo ou em parte, qualquer documento privado verdadeiro ou mudar-lhe substancialmente o sentido. 324: Aquele que, fabricando ou alterando, falsificar passes e bilhetes de estrada de ferro, ou doutra via pública de transporte do Estado, ou de empresa concessionaria, ou que os vender ao público, sabendo serem falsos ou terem sido falsificados, será punido com prisão até 2 anos e com multa. Nos casos de gravidade minima aplicar-se-á somente a multa.

Cons. 258 - Fazer, no todo ou em parte, escrito ou papel particular falso ou alterar o verdadeiro - 1 a 4 anos e multa de 1 a $20 \%$. 259: Incorrerá nas mesmas penas o que servir-se de papel falsificado pela forma estabelecida no art. antecedente, bem assi mo que concorrer para a falsidade como testemunha ou por qualquer outro modo. 250: Fabricar, falsificando ou alterando, vender ou usar passes, bilhetes de estrada de ferro ou de qualquer empresa de transporte pertencente á União, aos Estados, ás Municipalidades, ás Prefeituras ou a particulares -6 meses a 2 anos. $\S$ un. Possuir ou ter sob sua guarda, para fim criminoso... quaesquer dos titulos ou papeis falsificados na fórma deste e dos arts. anteriores - as mesmas, reduzidas de 1/3. 255: Falsificar telegramas ou expedi-los em nome de outrem, não estando para isso autorizado -1 mês a 1 ano. 
Art. 273 - Abusar de papel assinado por outrem, em que se tenha deixado espaço em branco, lançando ou mandando lançar nêle, sem autorisação do sinátario, áto gerador de efeitos jurídicos; ou usar cientemente de papel assim preenchido.

Pena - reclusão por 1 a 4 anos e multa de 500\$ a 5:000\$000.

Pr. 312 - Será punido com prisão até 5 anos aquele que, com o o fim de causar a alguem prejuizo patrimonial, social ou moral, imediato ou remoto, ou de obter para si ou para outrem vantagens da mesma natureza... 3) crear algum documento privado, abusando da assinatura ou da chancela reaes de outrem, ou dos timbres, etiquetas e monogramas impressos, quer no todo lhe forme o contexto, quer sómente lhe preencha os claros.

Cons. $338,6 .^{\circ}$ - Julgar-se-á crime de estelionato... abusar de papel com assinátura em branco, ou que se tenha apossado, ou que lhe haja sido confiado com a obrigação de restituir ou fazer dele uso determinado, e nele escrever ou fazer escrever um áto que produza efeito juridico em prejuizo daquele que o firmou -1 a 4 anos multa de 5 ə. $20 \%$.

Art. 274 - Consignar ou deixar que outrem consigne falsidade em escrituração sujeita á inspeção da autoridade policial ou em informação que a esta seja obrigado a prestar, com referencia á atividade propria, industrial, comercial ou profissional.

Pena - detenção por 15 dias a 3 meses ou multa de $200 \$$ a $2: 000 \$ 000$, se 0 fato não constituir crime punido com pena mais grave.

Pr. 315 - Aquele que em escrituração e registros sujeitos á inspeção da autoridade ou em documentos informativos que, sobre a profissão ou industria, que exercer, fôr obrigado a ministrar-lhe, cientemente consignar alguma falsidade ou consentir que outrem o faça, será punido com detenção até 3 meses ou com multa, e s0mente com esta no caso de culpa.

Cons. Omissa. 


\section{Capitulo IV}

\section{De outras falsidades}

Art. 275 - Punir-se-á com detenção por 3 meses a um ano ou multa de 1 a $5: 000 \$$ aquele que:

I - usar, como proprio, passaporte, titulo de eleitor, caderneta de reservista ou qualquer documento de identidade alheio;

II - ceder a outrem, para que dele se utilize, passaporte, titulo de eleitor, caderneta de reservista ou qualquer documento de identidade próprio ou de terceiro;

III - fóra do caso previsto no art. 181, recusar-se-á fornecer a funcionario ou encarregado de serviço público, no exercicio das funções ou na execução do serviço, informações sobre a identidade propria ou alheia, ou fornecê-las em desacordo com a verdade;

IV - induzir alguem em erro sobre a identidade propria ou alheia, para haver em beneficio alheio ou proprio, vantagem ilícita, ou para causar dano a outrem, atribuindo-se falsamente nome, ou estado, ou qualidade a que a lei atribua efeitos juridicos, uma vez que o fato não constitua crime diferente.

Pr. 432 - Será punido com detenção até 15 dias ou com multa aquele que.. usar de nome suposto ou mudado, sem que a mudança se tenha feito por fórma regular, nem tenha tido a devida publicidade. 317: Aquele que fabricando ou alterando, falsificar passaporte ou documento destinado a atestar a identidade pessoal de alguem, ou cientemente deles fizer uso, será punido com detenção até 3 meses e com multa. Este art. é aplicavel áquele que se utilizar, como próprio, de passaporte ou documento análogo verdadeiro, pertencente a outra pessôa. 474: Aquele que não fornecer á autoridade os dados concernentes á sua identidade pessoal, estado, profissão, domicilio e residencia, ou sobre qualidade inherente á essa pessôa, quando aquela justificadamente - inquira ou os exija, será punido com detenção até 2 meses, ou com multa, e na reincidencia com detenção por 1 a 3 meses e com multa.

Cons. 379 - Usar de nome suposto, trocado ou mudado... 15 a 60 dias. § un. Em igual pena incorrerá a mulher que condenada em ação de desquite, continua a usar o nome do marido. 380: Se, por meio de algum dos artificios precedentemente mencionados, alguem conseguir de outrem dinheiro ou utilidade - as do art. (1 $\left.\begin{array}{llll}1 & \text { a } & 4 & \text { anos }\end{array}\right)-$ 
Art. 276 - Punir-se-á com multa de 500\$000 a 5:000\$000 aquele que:

I - disfarçar o sexo, usando publicamente trajes impropros daquele a que pertença;

II - usar publicamente uniforme, hábito, ou qualquer distintivo de função publica, ministerio religioso, ou profissão que não exerça ou de cujo exercicio esteja suspenso;

III - arrogar-se indebitamente dignidade ou gráu academico, titulo, condecoração ou qualidade inherente a função, ministerio ou profissão, a que alude o inciso anterior.

Pr. 481 - Será punido com detenção até 1 mês ou com multa aquele que: 1) trajar de militar sem o ser, usar farda a que lhe não dê direito o seu posto; 2) usar o uniforme de repartição ou corporação oficial a que não pertença; 3) indebitamente fizer uso de distintivo com que a autoridade ou seus agentes se façam reconhecer como taes; 4) fingir-se de empregado público. A farda, o uniforme e o distintivo serão confiscados, sendo este entregue á autoridade, e aqueles restituidos a quem provar ser o seu legítimo dono ou recolhidos á corporação ou repartição própria. 432: Será punido com detenção até 15 dias ou com multa aquele que: 1) trajar de modo a fazer-se passar na vida diaria como pertencendo ao sexo oposto ao seu; 2) trajar de modo a fazer-se passar como exercendo profissão que não é a sua, ou pertencer a classe a que não pertence, ou usar de insignias e distintivos particulares de alguma classe ou profissão, sem tributo que lhes legitime o uso... os distintivos e insígnias serão confiscados.

\section{TITULO VII}

\section{Dos crimes contra o sentimento religioso e o respeito aos mortos}

\section{Capitulo I}

\section{Dos crimes referentes ao exercicio dos cultos}

Art. 277 - Punir-se-á com detenção por 1 mês a 1 ano ou multá de 500\$ a 5:000\$000 aquele que: 
I - impedir ou perturbar assembléa, cerimônia ou prática religiosa, que se realize com a assistencia do respectivo ministro, ou em local destinado ao culto ou aberto ou exposto ao público;

II - escarnecer publicamente de alguem por motivo de suas crenças ou funções religiosas;

III - desacatar ou profanar, publicamente ou em local destinado ao culto, cousa que seja objeto deste último ou consagrada ao seu exercicio;

§ único - Aumentar-se-á a pena quando o crime fôr cometido com ameaça ou violencia á pessôa.

Pr. 250 - Será punido com detenção até 6 meses ou com multa, aquele que: 1) impedir, embaraçar ou perturbar com manifestações: hostis ou ruidosas, o exercicio de algum culto religioso no recinto em que se deva celebrar; 2) ultrajar publicamente algum sacerdote, em razão de sua crença, ou dele escarnecer na ocasião em que estiver oficiando; 3) menoscabar os simbolos religiosos e das cousas consagradas ao culto, por ocasião e no recinto em que o mesmo se celebrar. A pena será a de prisão até 18 mezes quando se tiver, para cometer algum dos crimes acima enumerados, recorridos á violencia.

Cons. 185 - Ultrajar qualquer confissão religiosa, vilipendiando: ato ou objeto de seu culto, desacatando ou profanando os seus simbolos publicamente -1 a 6 meses. 186: Impedir, por qualquer modo, a celebração de cerimonias religiosas, ou perturbá-la no exercicio de seu culto -2 meses a 1 ano. 187: Usar de ameaças ou injurias contra os ministros de qualquer confissão religiosa, no exercicio de suas funções -6 meses a 1 ano.

\section{Capitulo II}

\section{Dos crimes contra o respeito devido aos mortos}

Art. 278 - Inhumar ou exhumar cadaver, com infração das disposições legaes.

Pena - detenção por 1 a 6 mezes ou multa de $500 \$$ a $2: 000 \$ 000$.

$\S$ unico - As penas serão aumentadas e cumuladas, se fôr intenção do agente ou consequencia do crime embaraçar ou obstar a ação de autoridade pública. 
Pro. Omisso.

Cons. 364 - Inhumar cadaver em contravenção dos regulamentos sanitarios, ou transportá-lo para fóra do cemiterio, salvo o caso de exhumação competentemente autorizada -1 a 6 meses. $\S$ un.: 0 facultativo que depois se reconheça que estava vivo ainda, incorrerá nas penas de multa de $100 \$$ a $200 \$$ e privação do exercicio da profissão por 1 ano.

Art. 279 - Impedir ou perturbar enterro ou outra cerimonia funeraria.

Pena - detenção por 1 mês a 1 ano ou multa de $500 \$$ a $5: 000 \$ 000$.

§ único - As penas serão aumentadas e cumuladas se o agente empregar ameaça ou violencia contra pessôa ou cousa.

Pr. 251 - Será punido com detenção até 3 meses aquele que... perturbar qualquer cerimonia funeraria, ou procurar vedar o acesso ao cemiterio a quem o demande para regularmente sepultar algum cadaver. A alinea do art. antecedente é aplicavel (no caso de violencia, prisão até 18 meses).

Con. Omissa.

Art. 280 - Violar ou danificar ou conspurcar ataude, sepultura ou urna funeraria.

Pena - reclusão por 1 a 3 anos.

Pr. 251 - Será punido com detenção até 3 meses aquele que... profanar ou violar algum tumulo. 1 ano.

Cons. 365 - Violar ou conspurcar as sepulturas - 2 meses a

Art. 281 - Subtrair ou ocultar cadaver, ou parte de cadaver, ou cinzas humanas.

Pena - reclusão por 1 a 3 anos.

$\S$ único - Aumentar-se-á a pena no caso do $\S$ único do art. 286.

Pr. 252 - Aquele que subtrair algum cadaver, alguma de suas partes ou os restos mortaes de alguem, da sepultura ou urna que os encerre, ou do poder da pessôa que os vele ou guarde, será punido com a prisão até 18 mezes. Se tiver tido por fim alterar ou frustrar diligencias que interessem á justiça, substituir ou suprimir o estado civil 
de alguma pessôa, a prisão será por 1 a 3 anos, salvo quando o fáto, por outro artigo, fôr passivel de pena mais grave.

Cons. Omissa.

Art. 282 - Profanar cadaver, ou esqueleto, destruindo-o, ou mutilando-o, ou vilipendiando-o, ou dispersando-lhe as cinzas.

Pena - reclusão por 2 a 5 anos.

Pr. 151. Será punido com prisão até 3 meses aquele que publicamente ultrajar cadaver insepulto.

Cons. 365 - Profanar cadaver; praticar sobre ele, antes ou depois da inhumação, qualquer desacato tendente a quebrantar o respeito devido aos mortos -2 meses a 1 ano.

\section{TITULO VIII}

\section{Dos crimes contra o pudor individual e a moralidade pública}

\section{Capitulo I}

\section{Dos crimes referentes á liberdade sexual}

Art. 283 - Ter conjunção carnal com alguem, mediante violencia, ameaça ou fraude.

Pena - reclusão por 3 a 10 anos.

$\S 10^{\circ}$ - Aumentar-se-á a pena :

I - Se o agente fôr ascendente ou afim em linha reta ascendente, pae ou mãe adotivo, irmão ou irmã, tutor ou curador da vítima;

II - se o crime fôr cometido com o concurso de duas ou mais pessôas ;

III - se do crime resultar para a vítima sífilis, blenorragia ou outra doença venérea.

$\S 20^{\circ}-$ A pena será:

I - de 10 a 30 anos, se do crime resultar a morte da vítima; 
II - de 5 a 15 anos, se do crime resultar, para a vítima, lesão grave ou gravissima.

Pr. 253 - Aquele que por violencia ou ameaça grave, constranger mulher maior de 16 anos á conjunção carnal será punido com prisão por 1 a 4 anos. A pena será por 2 a 6 anos.. 1) se a vítima eral sua pupila ou curatelada, ou para com ele estava em relação de parentesco que impedisse o casamento. 255: Aquele que constranger menor de 16 anos á conjunção carnal será punido com prisão: 1) por 1 a 4 anos, se a vítima fôr menor de 16 e maior de $14 ; 2$ ) por 2 a 6 se ainda não tiver 14 anos cumpridos. A pena será aumentada: 1) de 1/3 se a vítima fôr pupila do ofensor ou para com ele estiver em relação de parentesco que impeça o casamento.

Cons. 268 - Estuprar mulher virgem ou não, mas honesta - 1 a 6 anos. $\S 10^{\circ}$ Se a estuprada fôr mulher pública ou prostituta - 6 meses a 2 anos.

Art. 284 - Ter conjunção carnal com mulher virgem, maior de 16 e menor de 18 anos, de quem o agente fôr notoriamente noivo.

Pena - detenção ou reclusão por 1 a 4 anos.

$\S$ único - Aumentar-se-á a pena quando se verificar a hipótese do $\S 10^{\circ} \mathrm{n} .^{\circ}$ III do artigo precedente.

Pr. 257 - Aquele que tiver conjunção carnal com mulher virgem, menor de 18 anos e maior de 14, da qual seja notoriamente noivo, ou á qual tinha feito promessa de casamento em cuja seriedade a vítima devesse seriamente acreditar, será punido com prisão por 1 a 3 anos.

Cons. 267 - Deflorar mulher de menor idade, empregando sedução, engano ou fraude -1 a 4 anos.

Art. 285 - Atentar, mediante violencia, engano, ou fraude, contra o pudor de alguem, praticando na vítima ou fazendo-a praticar em si mesma ou em outrem ato libidinoso diverso da conjunção carnal.

Pena - reclusão por 2 a 6 anos.

$\S$ único - Aumentar-se-á a pena, verificada qualquer das hipóteses previstas no $\S 10^{\circ}$ do art. 292.

Pr. 256 - Aquele que constranger menor de 16 anos a praticar ou tolerar atos contrarios ao pudor, será punido com prisão até 4 anos. $\S$ un. Será punido com detenção até 6 meses e com multa aquele que 
constranger menor de 16 anos a assistir á prática de atos contrarios ao pudor.

Cons. 266 - Attentar contra o pudor de pessoa de um ou de outro sexo, por meio de violencia ou ameaça, com o fim de saciar paixões lascivas ou por depravação moral -1 a 3 anos. $\S 2 .^{\circ}$ Corromper pessôa menor de 21 anos, de um ou de outro sexo, praticando com ela ou contra ela atos de libidinagem - 2 a 4 anos.

Art. 286 - Embora sem o emprego de violencia, ameaça ou fraude, ter conjunção carnal ou atentar contra o pudor de pessoa, que, sob a autoridade ou guarda do agente ou de subordinado ou subalterno dele, esteja internada em asilo, hospital ou estabelecimento congênere, ou se ache presa ou detida, ou tenha ascendente, descendente, cônjuge, irmão ou irmã, detido ou preso.

Pena - detenção ou reclusão por 1 a 4 anos.

$\S$ único - A pena será de reclusão e aumentada, na hipótese do $\S 1 .^{\circ}$ n. ${ }^{\circ}$ III do art. 283.

Pr. Omisso.

Cons. Omissa.

Art. 287 - Raptar alguem, mediante violencia, ameaça ou fraude, para fim libidinoso.

Pena - reclusão por 3 a 10 anos.

$\S 10^{\circ}$ - Aumentar-sé-á a pena :

I - se a vítima sofrer conjunção carnal ou atentado ao pudor ;

II - se o agente não restituir a liberdade á vítima ou negarse a indicar o seu paradeiro.

$\S 2 .^{\circ}$ - O aumento será de dois terços até metade, se da conjunção carnal ou atentado ao pudor resultar uma das consequencias previstas no $\S 1 .^{\circ}$ n. ${ }^{\circ}$ III do art. 292

$\S 3 .^{\circ}$ - Diminuir-se-á a pena, se, antes de condenado e sem ter submetido a vitima a atentado ao pudor ou conjunção carnal, o agente a restituir á liberdade, reconduzindo-a ao logar de onde a houver tirado ou colocando-a em local seguro, á disposição da familia. 
Pr. 227 - Aquele que usando de violencia, de ameaças ou de artificios, raptar alguma mulher, ou, tolhendo-lhe a defesa, a retiver, será punido com prisão... por 1 a 3 anos; se tiver tido em mira comercio sexual fóra do casamento. 228: Aquele que conhecendo o estado da vítima raptar para fim libidinoso, mulher que sofra de que ele tenha previamente reduzido á incapacidade de resistir, será punido com prisão até 5 anos.

Cons. 270 - Tirar do lar doméstico para fins libidinosos qualquer mulher honesta, de maior ou menor idade, solteira, casada ou viuva, atraindo-a por sedução ou emboscada, ou obrigando-a por violencia, não se verificando a satisfação dos gosos genésicos -1 a 4 anos. $\S 10^{\circ} \mathrm{Se}$ a raptada fôr maior de 16 e menor de 21 anos e prestar o seu consentimento -1 a 3 anos. $\S 2 .^{\circ}$ Se ao rapto seguir-se defloramento ou estupro, o raptor incorrerá na pena correspondente a qualquer destes crimes, que houver cometido, com aumento da $6 .^{\mathrm{a}}$ parte. 271: Se o raptor, sem ter atentado contra o pudor e honestidade da raptada, restituir-lhe a liberdade, reconduzindo-a á casa de onde a tirou, ou colocando-a em logar seguro e á disposição da familia, sofrerá a pena de prisão celular por 6 meses a 1 ano. $\S$ un.: Se não restituir-lhe a liberdade ou recusar indicar o seu paradeiro -2 a 12 anos.

Art. 288 - Raptar, mediante violencia, ameaça ou fraude, mulher solteira ou viuva, para fim de casamento.

Pena - detenção ou reclusão por 1 a 3 anos.

$\S 10^{\circ}$ - Diminuir-se-á a pena :

I - quando o rapto se dér com o consentimento da raptada, maior de 16 anos.

II - quando se verificar a hipótese prevista no $\S 10^{\circ}$ do artigo precedente.

$\S 20^{\circ}$ - Realizado o casamento, só depois de ter sido este anulado haverá logar a ação criminal contra o raptor.

Pr. 227 - Aquele que usando de violencia, de ameaça ou de artificios, raptar alguma mulher, ou tolhendo-lhe a defesa a retiver, será punido com prisão por 6 meses a 2 anos, se tiver tido em mira o casamento... $\$ 10^{\circ} \mathrm{O}$ casamento do raptor com a raptada retroage os seus efeitos para excluir a criminalidade do rapto, salvo quando tiver sido anulado. $\$ 2 .^{\circ}$ A maior de 16 anos quando, por si, exercer - direito de representação contra o raptor, mas se com este tiver casado, o prazo da representação começará a correr do dia em que passar em julgado a sentença anulatoria do casamento.

Cons. Omissa. 


\section{Capitulo II}

\section{Dos crimes de corrupção}

Art. 289 - Praticar, na presença de menor de 18 anos, não moralmente corrompido, ato libidinoso; ou induzi-lo a presenciar ou praticar ato dessa natureza; ou promover-lhe ou favorecer-lhe de qualquer modo a corrupção.

Pena - reclusão por 1 a 3 anos e multa de 500 a 5:000\$000.

$\S$ único - Aumentar-se-á a pena se o crime fôr cometido mediante violencia, ameaça ou fraude.

Pr. 256 § un. - Será punido com detenção até 6 meses e com multa aquele que constranger menor de 16 anos a assistir á prática de atos contrarios ao pudor.

Cons. 266: $\S 10^{\circ}$ - Exercitar, favorecer ou facilitar a corrupção pessôa de um ou de outro sexo, menor de 21 anos, induzindo-a á prática de atos deshonestos, viciando a sua inocencia ou pervertendo de qualquer modo o seu, senso moral -6 meses a 2 anos. $\S 2 .^{\circ}$ : Corromper pessôa menor de 21 anos, de um ou de outro sexo, praticando com ela ou contra ela atos de libidinagem -2 a 4 anos.

Art. 290 - Induzir alguem a satisfazer a lascivia de terceiro.

Pena - reclusão por 1 a 3 anos e multa de 200 a 2:000\$000.

$\S$ único - Aumentar-se-á a pena :

I - se a vítima fôr menor de 18 anos;

II - se o crime fôr cometido com o fim de lucro;

III - se fôr cometido o crime com o emprego de violencia, ameaça ou fraude;

IV - se o agente fôr ascendente, descendente, pai ou mãe adotivos, padrasto ou madrasta, enteado ou enteada, marido, irmão ou irmã, tutor ou curador da vítima, ou pessôa a quem ela esteja confiada por motivo de educação, tratamento, vigilancia ou guarda.

Pr. 259 - Aquele que induzir menor de 16 anos a ter conjunção earnal com terceira pessôa ou a praticar com esta atos contrarios ao pudor, será punido com prisão até 3 anos. Verificadas as circunstan- 
cias dos ns. I e II do art. 255, ou a de ser o inculpado ascendente da vítima, observar-se-á o disposto na alínea do mesmo artigo sobre o aumento da pena. 260: Aquele que acolher menores, com ou sem distinção de sexos, para, entre si ou com terceiros, camalmente se unirem ou praticarem atos de libidinagem, será punido com prisão até 3 anos e com multa. A pena será aumentada de $1 / 3$ até metade, quando se tratar de exploração habitual ou lucrativa.

Cons. - Induzir alguem, por meio de enganos, violencias, ameaças, abuso de poder ou qualquer outro meio de coação, a satisfazer o desejo deshonesto ou paixões lascivas de ôtrem -1 a 2 anos.

Art. 291 - Punir-se-á com reclusão por 1 a 5 anos e multa de 1 a $5: 000 \$$ aquele que:

I - incitar ou induzir alguem a prostituir-se;

II — facilitar ou favorecer prostituição de outrem;

III - impedir que alguem abandone a prostituição;

IV - mantiver, por conta própria ou de terceiro, casa de tolerancia ou local destinado a encontros para fim libidinoso;

$\mathrm{V}$ - tirar proveito da prostituição alheia, participando diretamente de seus lucros ou fazendo-se sustentar, no todo ou em parte, por quem a exerça.

$\S 10^{\circ}$ - Aumentar-se-á a pena, nos casos dos ns. I, II e III, se ocorrer qualquer das circunstancias constantes do $\S$ unico do artigo precedente.

$\S 20^{\circ}$ - Aumentar-se-á a pena, no caso do $n .^{\circ} \mathrm{V}$, se ocorrer qualquer das circunstancias constantes do $\S$ unico, $n .^{\circ}$ I, III e IV do artigo precedente.

Pr. 261 - Aquele que com o fim de lucro, favorecer ou explorar a prostituição, será punido com prisão por 1 a 4 anos e com multa. $\S$ un. Este artigo s óse aplicará ao locador do predio em que se explore a prostituição, quando ela participar de seus lucros. 262: Aquele que aliciar mulher para a prostituição, ou a esta entregar mulher sobre quem exerça ascendencia legal, será punido com prisão por 2 a 4 anos. A pena poderá ser livremente atenuada quando maior a mulher e o inculpado um seu ascendente inválido. § un. - A mesma pena cominada neste artigo estará sujeito aquele que coagir alguma mulher a permanecer na prostituição, ou por qualquer modo procurar impedi-la de tomar ocupação honesta.

Cons. 277 - Excitar, favorecer ou facilitar a prostituição de alguem, para satisfazer os. desejos e' paixões de outrem -2 a 3 anos. $\S$ un. 
Se este crime fôr cometido por ascendente em relação a descendente, pelo tutor, curador ou pesôa encarregada da educação ou guarda de algum menor em relação a este; pelo marido com relação á propria mulher - 2 a 4 anos. 278: Manter ou explorar casas de tolerancia, admitir na casa em que residir pessôas de sexos diferentes ou do mesmo sexo, que aí se reunam para fins libidinosos; induzir mulheres, quer abusando de sua fraqueza ou miseria, quer constrangendo-as por intimidação ou ameaças a entregarem-se á prostituição; prestar, por conta propria ou de outrem, sob sua ou alheia responsabilidade, qualquer assistencia ou auxilio ao comercio da prostituição -1 a 3 anos e multa de 1 a 2:000\$000 - $10^{\circ}$ Aliciar, atrair ou desencaminhar, para satisfazer as paixões lascivas de outrem, qualquer mulher menor, virgem ou não, mesmo com o seu consentimento; aliciar, atrair ou desencaminhar, para satisfazer as paixões lascivas de outrem, qualquer mulher maior, virgem ou não, empregando para esse fim ameaça, violencia, fraude, engano, abuso de poder, ou qualquer outro meio de coação; reter por qualquer dos meios acima referidos ainda mesmo por causa de dividas contraídas, qualquer mulher maior ou menor, virgem ou não, em casa de lenocinio, obriga-la a entregar-se á prostituição as penas do dispositivo anterior.

Art. 292 - Promover, favorecer, ou facilitar a entrada, no territorio nacional, de quem venha nele exercer a prostituição; ou a saída de quem vá exerce-la no estrangeiro.

Pena - reclusão por 5 a 15 anos e multa de 5 a 20:000\$.

$\S$ único - Aumentar-se-á a pena, verificada qualquer das cireunstancias enumeradas no $\S$ unico do art. 297.

Pro. Omisso.

Cons. $278 \S 2 .^{\circ}-$ Os crimes de que tratam este art. e seu $\S 10^{\circ}$ serão punidos no Brasil, ainda que um ou mais atos constitutivos das infrações nele previstas, tenham sido praticadas em paiz estrangeiro.

\section{Capitulo III}

\section{Disposições comuns aos dois capitulos precedentes}

Art. 293 - Presumir-se-á a violencia, não se admitindo prova em contrario, quando a vítima de qualquer dos crimes definidos nos dois capitulos precedentes: 


\section{I - fôr menor de 16 anos;}

II - tiver mais de 16 e menos de 18 anos, e fôr descendente ou tutelada do agente, ou estiver sujeita á autoridade, guarda, cuidado ou vigilancia dele, por motivo de educação, tratamento, emprego ou custódia;

III - encontrar-se em estado de alienação mental, ou de inconciencia, ou de inferioridade física ou psíquica, provocado ou nã் pelo agente, que lhe impossibilite ou enfraqueça a resistencia.

$\S$ único - Não haverá, todavia, presunção absoluta de violencia ;

I - nos casos dos numeros I e II do $\S 1 .^{\circ}$, se a vítima fôr mulher pública;

II - no caso do n. ${ }^{\circ}$ III, se o agente não conhecer, nem tiver motivo para conhecer o estado da vítima.

Pr. 253 - A prisão será por 2 a 6 anos, se, para cometer o crime, tıver o inculpado reduzido previameste a vítima á incapacidade de resistir ou ao estado de inconciente; 2) se o tiver cometido, sabendo ser a vítima doente ou dificiente mental; 3) se, abstraindo da fraqueza inherente ao sexo, a vítima era incapaz de resistir por eficiencia física, permanente ou transitoria, acidental ou congênita; 4) se a vítima era sua pupila ou curatelada, ou para com ele estava em relação de parentesco, que impedisse o casamento. 255: aquele que constranger menor de 16 anos á conjunção carnal, será punido com prisão: 1 por 1 a 4 anos, se a vítima fôr menor de 16 anos e maior de 14 ; 2) por 2 a 6 anos, se ainda não tiver 14 anos cumpridos. A pena será aumentada: 1) de $1 / 3$, se a vítima fôr pupila do ofensor ou para ele estiver em relação de parentesco que impeça o casamento; 2) de $1 / 4 \mathrm{se}$, por motivo de tratamento, educação, instrução, domesticidade, patronagem, vigilancia ou custódia, a vítima lhe tiver sido confiada, ou habitar sob o mesmo tecto. § um. A favor das menores de 16 anos ha presunção relativa de violencia; e das menores de 14 presunção absoluta.

Cons. 268 - Estuprar mulher virgem ou não, mas honesta - 1 a 6 anos. § $10^{\circ}$ Se a estuprada fôr mulher publica ou prostituta - 6 meses a 2 anos. 269: Chama-se estupro o ato pelo qual o homem abusa com violencia de uma mulher, seja virgem ou não.

Por violencia entende-se, não só o emprego da força física, como o de meios que privarem a mulher de suas faculdades psiquicas, e assim da possibilidade de resistir e defender-se, como sejam o hipnotismo, o chloroformio, o éter e, em geral, os anestésicos e narcóticos. 272: Pre- 
sume-se cometido com violencia qualquer dos crimes... sempre que a ofendida fôr menor de 16 anos.

Art. $294-$ Os crimes definidos nos arts. 283 e seu $\S 10^{\circ}, 284$, 285, 286, 287, 288, 289 e 290 serão puniveis mediante queixa da vítima ou de quem tiver qualidade para representá-la. Apresentada a queixa, déla não poderá desistir o querelante, sem o consentimento do Ministério Publico.

$\S 10^{\circ}$ - Haverá logar, todavia, a ação pública:

I - se a vítima fôr miseravel, ou asilada em estabelecimento de assistencia, ou menor ou incapaz desassistida de representante legal;

II - se do crime resultar, para a vítima, lesão grave, gravissima ou morte;

III - se o crime fôr cometido com abuso do patrio poder, ou da qualidade de padrasto ou madrasta, ou da autoridade de tutor, curador ou funcionario público.

$\S 2 .^{\circ}-\mathrm{A}$ condenação importará:

I - na obrigação de dotar a ofendida.

a) se menor de 18 anos, fôr deflorada (art. 293);

b) se, mulher honesta, solteira ou viuva, fôr vítima de estupro (art. 292), atentado ao pudor (art. 294) ou rapto (arts. 296 e 297) ;

II — na perda do pátrio poder ou da autoridade conjugal ou na inhabilitação perpetua para o exercicio da tutela ou curatela, se fôr elementar ou agravante do crime a qualidade de pai, ou mãe, marido, tutor ou curador; importando mais a condenação por crime de estupro, atentado ao pudor, corrupção de menor ou lenocinio na perda do direito a alimentos e dos direitos sucessorios, com relação á pessôa da vítima.

$\S 3 .^{\circ}$ - Salvo no caso de lenocinio, o casamento do agente com a vítima extingue 0 crime e a condenação, com relação a todos os partícipes.

Pr. 43 - A ação repressora do M. P., além dos casos previsto\& na Parte Especial, será provocada pela reprecentação do ofendido nos seguintes:... 2) atentado ao pudor, violencia carnal, rapto e contagio 
de molestia venerea ou sifilítica... $\S$ un..: Nos casos previstos no n. II poderá o M. P. repetir a representação, quando se convencer de que o seu autor obedece a motivos reprovaveis. 44: Nos casos dos ns. I e II do art. precedente, tratando-se de menores ou de interditos por doença mental, poderão representar pelo ofendido aqueles que forem por ele legalmente responsaveis, na sua falta, quem justificar, por suas relações de parentesco, interesse moral na punição do culpado. 45: A representação será dispensavel, quando, de qualquer dos crimes previstos no n. II do art. 43, resultar para o ofendido: 1) morte ou lesão corporal grave; 2) doença mental incuravel, oou de cura duvidosa ou demorada; 3) inhabilitação permanente para o trabalho; 4) perda de algum órgão, ou de membro, ou da respectiva função; 5) perda de algum sentido ou da palavra. 46: Embora as hipóteses do art. precedente não se verifiquem, da representação se prescindirá quando: 1) por debilidade mental, ignorancia ou simpleza não puder o ofendido ou quem por ele devesse representar avaliar em toda a sua extensão e gravidade o mal infligido; 2 se tratar de menor moralmente abandonado ou desassistido sem curatela; 3 ) tiver sido o crime cometido pelo proprio pae, padastro ou curador do menor ou do interdito ofendido; 4) se tratar de pessôa humilde, reduzida ao silencio por medo do seu ofensor. 42: Não obsta o direito de representação a que o ofendido diretamente dê queixa, mas iniciada a ação publica, a representação é irretratavel.

Cons. 274 - Nestes crimes haverá logar o procedimento oficial da justiça sómente nos seguintes casos: 1) se a ofendida fôr miseravel ou asilada de algum estabelecimento de caridade; 2) se da violencia carna] resultar morte, perigo de vida ou alteração grave na saude da ofendida; 3) se o crime fôr perpetrado com abuso do patrio poder, ou da autoridade do tutor, curador ou preceptor. 278 § $3 .^{\circ}$ : Nas infrações de que trata este art. (lenocinio) haverá logar a ação penal: a) por denuncia do M. P.; b) mediante queixa da vítima ou seu representante legal; c) mediante denúncia de qualquer pessôa, 273: Alem da pena, e da interdição em que incorrerá tambem, o ascendente perderá todos os direitos que a lei lhe confere sobre a pessôa e bens da ofendida. 276: Nos casos de defloramento, como nos de estupro de mulher honesta, a sentença que condenar o criminoso o obrigará a dotar a ofendida. § un. Não haverá logar imposição da pena se seguir-se o casamento, a aprasimento do representante legal da ofendida, ou do juiz dos órfãos, nos casos em que lhe compete dar ou suprir o consentimento, ou a aprasimento da ofendida, se fôr maior. 


\section{Capitulo IV}

\section{Do ultraje público ao pudor}

Art. 295 - Praticar obscenidade, mediante gesto, palavra ou ato. em logar público, ou aberto ou exposto ao público.

Pena - detenção por 3 meses a 1 ano, ou multa de 1 a $3: 000 \$ 000$.

Pr. 264 - Aquele que, por atos, palavras ou gestos, ofender publicamente o pudor, será punido com detenção até 3 meses ou com multa:

Cons. 282 - Ofender os bons costumes com exibição impudicas, atos ou gestos obscenos, atentatorios do pudor, praticados em logar público ou frequentados pelo público, e que, sem ofensa á honestidade individual da pessôa, utrajam e escandalisam a sociedade.

Art. 296 - Punir-se-á com detenção por 6 mezes a 2 anos, ou multa de 2 a 5:000\$, ou ambas cumulativamente, aquele que:

I - publicar, na qualidade de autor ou de editor, vender, expuser á venda, reproduzir, distribuir ou de outro modo dér á publicidade ou puzer em circulação escrito, desenho ou imagem, que ofenda a zaoralidade pública;

II - fabricar, importar, vender, expuser á venda, reproduzir, distribuir ou de outra maneira puser em circulação objeto ofensivo ao pudor;

$\S 1 .^{\circ}$ - Aumentar-se-ão e acumular-se-ão as penas se o crime fôr cometido em espetáculo público ou pelo rádio.

$\S 2 .^{\circ}$ - Serão destruidos os escritos, desenhos, imagens ou objetos obscenos.

Pr. 265 - Será punido com detenção até 6 meses ou com multa aquele que: 1) fizer, pela imprensa, publicação obscena; 2) vender, expuzer á venda ou por outio qualquer modo concorrer para que circule livro, folheto, periódico, jornal, desenho, estampa ou pintura que, por obscenos, ofendam a moral pública; 3) fabricar ou importar para vender ao público os objetos acima enunciados ou quaesquer outros igualmente obscenos. 
Cons. 282 - A ofensa á moral pública ou aos bons costumes, feita de qualquer modo pela imprensa, é punida com a pena de prisão celular, por 6 meses a 2 anos e da perda do objeto de onde constar a mesma ofensa. § un. E' proibido, sob a mesma pena deste artigo, vender, expôr, á venda ou, por algum modo, concorrer para que circule qualquer livro, folheto, periódico ou jornal, gravura, desenho, estampa, pintura ou impresso de qualquer natureza; sendo que contenha ofensa á moral pública ou aos bons costumes.

Art. 297 - Importunar alguem em logar público, de modo vexatorio ao pudor.

Pena - multa de $200 \$$ a $1: 000 \$ 0000$.

Pr. 450 - Aquele que, por palavras que lhe dirija ou pela insistencia com que o siga, importunar alguma mulher na via pública, de maneira vexatoria ao seu pudor, será punido com detenção até 10 dias ou com multa. 451: aquele que importunar alguem na via pública com solicitações libidinosas será punido com reclusão até 20 dias ou com multa.

Cons. Omissa.

\section{TITULO IX}

\section{Dos crimes contra a familia}

\section{Capitulo I}

\section{Dos crimes referentes ao casamento}

Art. 298 - Contrair, sendo casado, outro casamento; ou não o sendo, contrair casamento com quem saiba ser casado.

Pena - reclusão por 2 a 5 anos na primeira hipótese, e detenção ou reclusão por 1 a 3 na segunda.

$\S$ único - Anulado por qualquer notivo o primeiro casamento ou anulado o segundo por outro motivo, que não o de bigamia, haver-se-á por extinto o crime, cessando, se já houver condenação, a execução e os efeitos da sentença. 
Pr. 266 - Aquele que contrair casamento, sendo casado, ou, não sendo, contraí-lo com pessôa que saiba ainda ser casada, será punido com prisão por 1 a 4 anos, na primcira hipótese, e na segunda com detenção até 1 ano. $\mathrm{Na}$ primeira hipótese, quando o inculpado fôr poligamo, a prisão será por 2 a 6 anos.

$\S$ único - Nenhuma pena se aplicará aquele que se tiver novamente casado incuzido em erro sobre a sua capacidade nupcial pelo outro contraente, mas a deste será aumentada de 1/3.

Cons. 283 - Contrair casamento mais de uma vez, sem estar o anterior dissolvido por sentença de nulidade ou por morte do outro cônjuge -1 a 6 anos. $\S$ un. Se a pessôa tiver prévio conhecimento de que é casado aquele com quem contrair casamento, incorrerá nas penas de cumplicidade.

Art. 299 - Induzir em erro essencial o outro contraente, ocultando-lhe fraudulentamente, ao contraír casamento, a existencia de impedimento, que não o resultante de casamento anterior não dissolvido.

Pena - detenção por 3 meses a 1 ano, ou multa de 1:000\$000 a $5: 000 \$ 000$.

§ único - A ação criminal só poderá ser intentada mediante queixa do contraente induzido em erro, e depois de transitar em julgado a sentença, que, por motivo do impedimento ocultado, anular o casamento.

Pr. 267 - Aquele que, ao contrair casamento, tiver induzido em erro essencial o outro contraente, ou lhe tiver ocultado impedimento que não seja o resultante de casamento anterior, será punido com prisão até 4 anos. A ação penal dependerá da representação do contraente lesado, e só se iniciará depois de passar em julgado a sentença que anular o casamento por um daqueles motivos.

Cons. Omissa.

Art. 300 - Celebrar casamento, ou funcionar como oficial do registro em sua habilitação ou celebração, conhecendo e deixando de opôr impedimento que o torne nulo (Cod. Civ. arts. 207 e 208).

Pena - detenção por 6 meses a 2 anos ou multa de 1 a $10: 000 \$ 000$. 
$\S 10^{\circ}$ - Incorrerá na multa de 500\$000 a 2:000\$000 aquele que, como celebrante ou oficial do registro, houver concorrido culposamente para a realização de casamento nulo.

$\S 2 .^{\circ}-$ Aplicar-se-á nos casos deste art. o disposto no $\S$ unico do art. precedente.

Pro. Omisso.

Cons. Omissa.

Cod. Civ. 227 - Incorre na multa de $100 \$$ a $500 \$$, além da responsabilidade penal aplicavel ao caso, o oficial do registro. 1) que não declarar os impedimentos cuja oposição se lhe fizer, ou cuja existencia, sendo aplicavel de oficio, lhe constar com certeza. 225: Nas mesmas penas incorrerá o juiz... 2) que se abstiver de opô-los quando lhe constarem e forem dos que se opoem ex-oficio.

\section{Capitulo II}

\section{Dos crimes referentes ao estado de familia}

Art. 301 - Punir-se-á com reclusão por 2 a 6 anos aquele que : I - fizer inscrever no registro civil nascimento que não se tenha verificado;

II - suprimir ou alterar o estado civil de recem-nascido, ocultando-o ou substituindo-o por outro.

$\S$ unico - Aumentar-se-á a pena se o registro do nascimento se fizer, mediante atestado ou documento falso.

Pr. 268 - Será punido com prisão até 4 anos aquele que: 1) fizer inscrever no registro civil nascimento que se não tenha verificado; 2) suprimir ou alterar o estado civil de algum recem-nascido, ocultando-o ou substituindo-o por outra pessôa. Verificada a circumstancia do n..$^{-} 3$ do art. 101 (se o crime se originar de sentimentos bons), a pena será livremente atenuada.

Cons. 285 - Inventar gestação e dar parto alheio por seu; ou, tendo realmente dado á luz filho vivo ou morto, sonegá-lo ou substitui-lo - 6 meses a 2 anos. § un. Em egual pena incorrerá: 1) o marido ou pessôa que cohabite com a ré e que auxiliar ou simplesmente assentir á perpretação do crime; 2) o facultativo ou parteira, que abusando da sua profissão, cooperar para o mesmo resultado, impondo-se-lhes mais 
a pena de privação do exercicio da profissão por tempo igual ao da prisão. 286: Deixar de fazer, dentro de 1 mês, no registro civil a declaração do nascimento de creança nascida, como faze-la a respeito da creança que jamais existira, para crear ou extinguir direito em prejuizo de terceiro -6 meses a 2 anos.

Art. 302 - Punir-se-á com reclusão por 1 a 4 anos aquele que promover o suprimento ou a retificação do registro do proprio nascimento ou de nascimento de filho, mencionando falsamente a idade, ou a filiação, ou a nacionalidade, para obter isenção de obrigação ou aquisição de direito.

Pr. Omisso.

Cons. Omissa.

Art. 303 - Internar ou deixar em asilo de expostos ou instituição de assistencia, filho próprio ou alheio, legítimo ou reconhecido, atribuindo-lhe falsa filiação ou ocultando maliciosamente a verdade.

Pena - reclusão por 1 a 5 anos.

$\S$ único - Aumentar-se-á a pena, se o agente houver cometido o crime por motivo torpe.

Pr. 269 - Aquele que, obedecendo a movel de vingança ou de lucro, para si ou para outrem, depuzer ou fizer internar alguma creança em estabelecimento de caridade ou de assistencia, atribuindo-lhe falsa. filiação, ou concientemente ocultando a verdadeira, será punido com prisão por 1 a 4 anos e com multa.

Cons. 287 - Fazer recolher a qualquer asilo de beneficencia, ou. establecimento congênere, filho legítimo ou reconhecido, para prejudicar direitos resultantes do seu estado civil - 1 a 4 anos.

Capitulo III

\section{Dos crimes referente á moralidade da familia}

Art. 304 - Cometer adultério a mulher :

Pena - detenção por 15 dias a 6 meses, ou multa de $500 \$ 000$ a 2:000\$000. 
$\S 10^{\circ}-$ Em pena igual incorrerão:

I - o marido que tiver concubina teúda e manteúda;

II - a concubina;

III - o co-réo da adultera.

$\S 20^{\circ}-\mathrm{A}$ ação criminal só poderá ser intentada mediante queixa do conjuge ofendido, dentro em um mês da propositura da ação de desquite, com fundamento em adulterio. cônjuge :

$\S 3 .^{\circ}$ - Não poderá intentar ação criminal por adulterio o

I - que nele houver consentido;

II - que o tiver perdoado;

III - que houver abandonado o domicilio conjugal.

$\S 40^{\circ}$ - Extinguem o crime e a condenação, com referencia a quantos hajam participado daquele:

I - o perdão ou a morte do conjuge ofendido;

II - a anulação do casamento.

Pr. Omisso.

Cons. 279 - A mulher casada que cometer adulterio será punida com... 1 a 3 anos. $\S 10^{\circ}-\mathrm{Em}$ igual pena incorrerá: 1) — o marido que tiver concubina teúda e manteúda; 2) a cuncubina; 3) o co-réo adúltero. $\$ 20^{\circ}$ - a acusação deste crime é lícita sómente aos cônjuges, que ficarão privados do exercicio desse direito ou, por qualquer modo, houverem consentido no adulterio. 280: Contra o co-réo adultero não serão admissiveis outras provas, senão o flagrante-delito e a resultante de documentos escritos por ele. 281: A ação de adulterio prescreve no fim de 3 meses contados da data do crime. $\S$ un. 0 perdão de qualquer dos cônjuges ou sua reconciliação extingue todos os efeitos de acusação e condenação.

Art. 305 - Manter relações incestuosas com ascendente ou descendente, consanguineo ou afim em linha recta, ou irmão ou irmã, de maneira a provocar escandalo público.

Pena - detenção por 1 a 5 anos.

$\S$ único - Aumentar-se-á a pena para o maior de 18 anos, que cometer o crime com menor dessa idade.

Pro. Omisso.

Cons. Omissa. 
Capitulo IV

\section{Do abandono moral e material da familia}

Art. 306 - Faltar, sem justo motivo, ao dever legal de sustentar filho menor ou cônjuge, deixando de ministrar o necessario ou de pagar, durante dois ou mais meses consecutivos, a pensão alimenticia judicialmente fixada.

Pena - detenção por 3 meses a 1 ano ou multa de 1:000\$000 a 10:000\$000, sendo aplicadas ambas cumulativamente, no caso de reincidencia.

Pro. Omisso.

Cons. Omissa, no que se refere ao conjuge e aos filhos maiores de 16 anos (292, III).

Art. 307 - Faltar, sem justo motivo, durante dois ou mais meses consecutivos, á obrigação de pagar a descendente, que não seja filho menor ou a ascendente os alimentos judicialmente fixados.

Pena - detenção por 1 a 3 meses ou multa de 500\$ a 5:000\$, que serão aplicadas cumulativamente no caso de reincidencia.

Pr. Omisso.

Cons.

Art. 308 - Desencarregar-se de filho menor de 18 anos, entregando-o a longo termo a pessôa, com a qual saiba ou deva presumir que ele se acha moral ou materialmente em perigo; ou recusar-se a retomá-lo; ou desamparar filho ou cônjuge, no caso de grave enfermidade.

Pena - detenção por 1 a 6 meses ou multa de 500\$ a 5:000\$000.

Pro. Omisso.

Cons. 292, III - Negar, sem justa causa, ao filho legítimo, natural ou adotivo, menor de 16 anos de idade, os alimentos ou subsidios, que lhe deve em virtude de lei ou de uma convenção ou decisão de autoridade competente; deixar de pagar, tendo recursos, a sua manu- 
tenção, estando ele confiado a terceiro, com essa obrigação; recusar-se a retomá-lo; abandonar, embora não o deixando só, quando ele se achar em perigo de morte ou em perigo grave e iminente para a sua saude - 8 dias a 2 meses e multa de $20 \$$ a $200 \$$, além da inhibição do patrio poder. IV: desencarregar-se do filho, entregando-o a longo termo ao cuidado de pessôas, com as quaes sabia ou devia presumir que ele se acha moral ou materialmente em perigo - 15 dias a 3 meses, e de 1 a 6 meses, se a entrega foi feita com o fito de lucro.

Art. 309 - Permitir que menor de 18 anos, sujeito a seu poder ou confiado á sua guarda ou cuidado:

I - frequente casa de jogo ou mal afamada, ou gente viciosa ou de má vida;

II - frequente ou participe de espetáculo capaz de pervertê-lo ou ofender-lhe o pudor, ou trabalhe em casa de espetaculos dessa natureza;

III - resida ou trabalhe em casa de prostituta;

IV - mendigue ou sirva a mendigo para excitar a comiseração pública.

Pena - detenção por 1 a 3 meses ou multa de 100\$ a 1:000\$000.

Pr. Omisso.

Cons. 292, XI - Mendigar em companhia de menor de 18 anos, ainda que seja filho, ou menor sujeito a seu poder ou confiado á sua guarda ou cuidado, ou a mendigar, francamente, ou permitir que a pretexto de cantar, tocar algum instrumento, representar, oferecer qualquer objéto á venda, ou cousa semelhante, ou servir-se desse menor com o fim de excitar a comiseração publica. - 1 a 3 meses com a inhibição do pátrio poder, se fôr o pae ou a mãe. XII: Permitir que menor de 18 anos, sujeito a seu poder ou confiado á sua guarda ou ao seu cuidado: a) frequente casa de jogo proibido ou mal afamada, ou ande em companhia de gente viciosa ou de má vida; b) frequente casa de espetáculos pornográficos onde se representam ou apresentam cenas que podem ferir o pudor ou a moralidade do menor, ou provocar os seus instintos maus ou doentios; c) frequente ou resida, sob pretexto serio, em casa de prostituta ou de tolerancia, 15 dias a 2 meses ou multa de $20 \$$ a $200 \$$ ou ambas. § un. Se o menor vier a sofrer algum atentado sexual ou se prostituir, a pena pode ser elevada ao dobro ou ao triplo, conforme - responsavel pelo menor tiver contribuido para a frequencia ilícita deliberadamente ou por negligencia grave ou continuada. 


\section{Capitulo V}

\section{Dos crimes contra a autoridade dos titulares do patrio poder, tutela e curatela}

Art. 310 - Punir-se-á com detenção por 1 mês a 1 ano ou multa de $200 \$ 000$ a 2:000\$000 aquele que :

I - induzir alienado ou menor de 18 anos a fugir do logar em que se achar por determinação da pessôa a cuja autoridade ou guarda estiver sujeito:

II - confiar a outrem, sem ordem do pae, ou mãe, tutor, curador ou autoridade que lho houver entregue, alienado ou menor de 18 anos; ou não o apresentar, sem justo motivo, a quem tenha o direito de reclama-lo;

III - subtrair, para fim que não seja libidinoso, ou matrimonial, ou de resgate, alienado ou menor de 18 anos ao titular do patrio poder, tutela ou curatela, ou áquele a cuja guarda estiver eonfiado pela autoridade.

§ único - A pena será de reclusão por 1 a 5 anos, se c agente não restituir o menor ou alienado, que houver subtraído, nem indicar o seu paradeiro.

Pr. 318 - Aquele que subtrair menor ou interdicto á autoridade dos paes, ou tutor do curador, será punido com detenção por 3 a 9 meses. Salvo as exceções previstas na Parte Geral, a representação é necessaria. $\S 10^{\circ}$ - A restituição do menor ou interdicto, antes da sentença, extingue a ação penal; depois da sentença faz cessar a execução da pena e, com esta, todos os seus efeitos. $\S 20^{\circ}-A$ restituição só produzirá os efeitos acima especificados, quando o menor ou interdito não tiver sido vitima de maus tratos e privações, ou de atentado ao seu pudor.

Cons. 292. V: Subtrair ou tentar subtrair menor de 18 anos ao processo contra ele intentado em virtude da lei sobre a proteção á infancia e adolescencia; subtraí-lo ou tentar subtraí-lo, embora com o seu consentimento, á guarda das pessôas a quem a autoridade competente - houver confiado; induzi-lo a fugir do logar onde se achar colocado por aquele a cuja autoridade estiver submetido, ou a cuja guarda estiver confiado ou a cujos cuidados estiver entregue; não o apresentar, 
sem legítima excusa, ás pessôas que tenham o direito de reclamá-lo 30 dias a 1 ano e multa de 100\$ a 1:000\$. Se o culpado fôr o pae ou a mãe ou o tutor as penas podem ser elevadas ao dobro. $\S$ un. - Não restituir o menor nos casos deste número - 2 a 12 anos. -

\title{
TITULO $\mathrm{x}$
}

\section{Dos crimes contra a pessôa}

\author{
CAPitulo I \\ Dos crimes contra a incolumidade pessoal
}

\section{SEç̧ão I}

Dos crimes contra a vida

Art. 311 - Matar alguem:

$\S 10^{\circ}$ - Se o homicidio fôr cometido

I - por motivo torpe;

II - para facilitar a execução ou a ocultação de outro crime, ou para conseguir ou assegurar, em proveito proprio ou alheio, a impunidade ou os proventos de crime diverso;

III - mediante o emprego de tóxico, sevicias, privação de alimentos, incendio, explosão, ou qualquer outro meio insidioso, cruel ou de perigo commum.

Pena - reclusão por 20 a 30 anos.

§ 2. - Se o homicidio fôr cometido:

I - por motivo futil;

II - contra ascendente, descendente ou cônjuge, uma vez que o agente tenha conhecimento do vínculo e não se ache sob o influxo de violenta emoção provocada por ato injusto de outrem;

III - contra chefe de Eistado estrangeiro, que se encontre no territorio nacional, ou contra representantes diplomático ou consular de outra nação, ou ministro de culto reconhecido pelo Estado, territorio nacional, ou contra representante diplomático ou con- 
suas funções, uma vez que o agente não se ache sob o influxo de violenta emoção provocada por ato injusto de outrem e tenha conhecimento da qualidade do ofendido;

IV - á traição, com disfarce, mediante emboscada ou em outras condições de tempo, logar ou p essôa, que dificultem ou impossibilitem a defesa da vitima.

Pena - reclusão por 15 a 30 anos.

$\S 3 .^{\circ}-$ Se o homicidio fôr:

I - preterintencional;

II - cometido sob o influxo de emoção violenta provocado por ato injusto de outrem;

III - por motivo de reconhecida nobreza.

Pena - reclusão por 2 a 10 anos.

$\S 4 .^{\circ}-$ Se o homicidio fôr culposo.

Pena - detenção por 1 a 3 anos.

$\S 50^{\circ}$ - Se o homicidio não se classificar em nenhum dos $\S \S$ precedentes.

Pena - reclusão por 5 a 20 anos.

Pr. 165 - Aquele que matar alguem será punido com prisão por 5 anos no minimo, ou com detenção se sómente responder por culpa. $\S$ un. A pena será agravada quando o homicida cometer o crime: 1) - sabendo ser a vítima seu ascendente, descendente, conjuge, irmão ou irmã; 2) - como filiado a quadrilha ou bando, ou assistido por outrem; 3) - mediante o uso de automovel, aviões ou barcos a motor, ou de outro veículo ao qual imprimisse velocidade excessiva ou que maliciosamente manobrasse; 4) - aproveitando-se de crime do perigo comum, doloso ou culposo, que tiver cometido ou que outro cometesse; 5) - para tornar possivel preparar, facilitar, executar ou consumar outro crime, ou porque á consumação deste se opuzesse alguem; 6) para assegurar proveitos do crime anterior, ou garantir a propria fuga ou de outrem, por crime cometido ou que se tentasse cometer; 7) por paga antecipada, consequente ou prometida; 8) - contra pessôa que, pela idade ou doença, se não pudesse defender, ou o não pudesse por se encontrar em estado momentaneo de inconciencia ou por se lhe haver previamente tolhido a defesa. 166; Aquele que, com atos tendentes a produzir lesão corporal, causar a morte, descontar-se-á, de $1 / 3$ até metade a pena de homicidio. 
Cons. 294 - Matar alguem: $\S 10^{\circ}$ - Se o crime fôr perpetrado com qualquer das circunstancias agravantes mencionadas nos $\S \S 2,3$, $6,7,8,9,10,11,12,13,16,17,18$ e 19 do art. 39 e $\S 2 .^{\circ}$ do art. 41 - prisão celular por 12 a 30 anos. $\S 20^{\circ}$ - Se o homicidio não tiver sido agravado pelas referidas circunstancias -6 a 24 anos. $295 \S 1$. $^{\circ}$ : Se a morte resultar, não da natureza e séde das lesões, e sim das condições personalissimas do ofendido -4 a 12 anos. $\S 2 .^{\circ}-$ Se resultar, não porque o mal fosse mortal, e sim por ter o ofendido deixado de observar o regime medico-higienico reclamado pelo seu estado - 2 a 8 anos. 195: Aquele que, por imprudencia, impericia ou negligencia na sua arte ou profissão, ou por inobservancia de alguma disposição regulamentar, cometer ou fôr causa involuntaria, direta ou indiretamente, de um homicidio - 2 meses a 2 anos.

Art. 312 - Matar infante, por ocasião do parto ou logo depois do nascimento, para ocultar a deshonra própria ou a de ascendente, descendente, irmã ou mulher.

Pena - reclusão por 2 a 6 anos.

Pr. 168 - Aquela que, durante parto, ou ainda sob a influencia do estado puerperal, matar o filho recemnascido, será punida com prisão até 3 anos ou com detenção por 6 mezes n omínimo. 169 - Aquele que, para esconder a deshonra da filha ou irmã, cuja gravidez corresse ocultamente, lhe matar o filho recem-nascido, antes de conhecido o parto, se descontará por metade a pena de prisão em que incorrer, podendo o juiz converte-la em detenção se o art... fôr aplicavel (criminosos primarios).

Cons. 298 - Matar recem-nascido, isto é, infante, nos 7 primeiros dias de seu nascimento, quer empregando meios diretos e ativos, quer recusando á vitima os cuidados necessarios á manutenção a sua vida e a impedir a morte -6 a 24 anos. $\S$ un. Se o crime fôr perpetrado pela mãe, para ocultar a deshonra própria - 3 a 9 anos.

Art. 313 - Induzir ou instigar alguem a suicidar-se ou prestarlhe auxilio para que o faça, uma vez que o suicidio seja consumado ou tentado.

Pena - reclusão por 2 a 6 anos.

$\S$ único - Aumentar-se-á a pena, de dois terços ao triplo:

I - se o motivo determinante do crime fôr egoístico ou torpe;

II - se a vítima fôr menor de 18 anos, ou devido a alienação mental, embriaguez ou outro motivo, não estiver em seu perfeito juizo. 
Pr. 107 - Aquele que obedecendo a movel egoistico, incitar alguem a suicidar-se, ou para que o faça prestar-lhe assistencia... prisão até 5 anos, desde que o suicidio tiver sido tentado (Obs.: se o suicidio se consumar não haverá crime?)

Cons. 299: Induzir ou ajudar alguem a suicidar-se, ou, para esse fim, fornecer-lhe meios com conhecimento de causa -2 a 4 anos.

Art. 314 - Provocar o próprio aborto, isto é, a expulsão prematura ou a destruição, no proprio ventre, do produto da concepção, ou consentir que outrem o faça.

Pena - detenção por 6 meses a 2 anos. própria.

$\S 1^{\circ}$ - Se o crime fôr cometido para ocultar a deshonra

Pena - detenção por 1 a 6 meses.

§ $2^{\circ}$ - Não será punivel a provocação de aborto feita pela gestante :

I - quando o aborto não se verificar;

II - quando a gravidez resultar de estupro.

Art. 322 - Provocar em outrem o aborto:

$\S 10^{\circ}$ - Se o crime fôr cometido por ascendente, descendente, cônjuge, irmão ou irmã, para ocultar a deshonra da gestante e com o consentimento desta.

Pena - detenção por 1 a 6 meses.

$\S 2 .^{\circ}-$ Se o crime fôr cometido com o consentimento da gestante, fóra do caso previsto no $\S 1 .^{\circ}$.

Pena - reclusão por 1 a 4 anos.

$\S 3 .^{\circ}-$ Se o crime fôr cometido sem o consentimento da gestante.

Pena - reclusão por 2 a 8 anos.

$\S 4 .^{\circ}$ - As penas cominadas nos $\S \S$ anteriores serão aumentadas :

I - de um a dois terços, se a gestante em consequencia do aborto ou dos meios empregados para provocá-lo, sofrer lesão grave ou gravissima;

II - de dois terços ao triplo, se sobrevier a morte da gestante, em consequencia do aborto ou dos meios empregados para provocá-lo.

Art. 315 - Provocar culposamente em outrem o aborto ou 0 parto prematuro, conhecendo a existencia da gravidez.

Pena - multa de 500\$000 a 5:000\$000. 
Art. 316 - Não será punivel o aborto provocado por medico habilitado, quando outro meio não houver de salvar a vida da gestante.

§ $10^{\circ}$ - Tambem não será punivel o aborto provocado por médico habilitado, com o consentimento da gestante ou, se esta fôr incapaz de presta-lo, de seu representante legal, quando a gravidez resultar de estupro.

§ 2. - Responderá, em todo o caso, pela morte ou lesão resultante da intervenção, o médico que se houver culposamente.

Art. 317 - Importar, fabricar, anunciar ou expôr á venda subs tancia ou objéto destinado á provocação do aborto.

Pena - multa de 500\$000 a 2:000\$000.

Pr. 170 - A mulher que causar o próprio aborto, ou permitir que outrem o cause, que destruir no proprio ventre o seu fruto, ou permitir que outrem o destrua, será punida com detenção. 171: Aquele que causar o aborto de alguma mulher, ou the destruir no ventre o seu fruto, será punido com prisão até 3 anos, se o fez com o seu consentimento, ou com prisão até 5 anos, se dele prescindiu. A aplicação da pena regular-se-á pelo art. 129, quando se verificarem as condições de parentesco e sigilo nele estabelecidas. 172: Aquele que causar a morte de alguma mulher por lhe haver determinado o aborto ou por lhe haver destruido no ventre o fruto da concepção será punido com prisão por 2 a 6 anos, se provar ter agido com o consentimento da vitima ou por 3 a 9 anos, no caso contrario. (Obs. E e se resultar lesão grave ou gravissima?). 173: Não será passivel de pena o medico diplomado que, para salvar a vida de alguma mulher, lhe causar o aborto como recurso extremo (Obs. Basta o diploma para autorizar o exercicio da profissão?) $\S 10^{\circ}$ - Sempre que fôr possivel obter o consentimento prévio, deste dependerá a isenção da pena. $\S 20^{\circ}-0$ consentimento será dado: 1) pela propria mulher, se o seu estado o permitir; 2) - por seu marido ou companheiro (?) de vida conjugal; 3) por seu pae ou mãe ou parentes que no momento lhe prestarem assistencia. $\S 30^{\circ}$ - A falta de conhecimento prévio, quando impossivel de obter-se, será suprida pela afirmação do médico de haver pautado a intervenção pelos ditames da ética profissional. $\S 4 .^{\circ}$ - Se do aborto resultar a morte da mulher, por impericia, imprudencia ou negligencia do medico que 0 tiver causado, a este aplicar-se-á a pena de detenção por 6 meses no mínimo. 
Cons. 300 - Provocar aborto, haja, ou não, a expulsão do fruto da concepção. No $10^{\circ}$ caso -2 a 6 anos - No $20^{\circ}-6$ meses a 1 ano. $\S 10^{\circ}$ - Se, em consequencia do aborto ou dos meios empregados para provoca-lo, seguir-se a morte da mulher: -6 a 24 anos. $\S 2 .^{\circ}-$ Se o aborto fôr provocado por médico ou parteira legalmente habilitada para o exercicio da medicina a mesma pena e a da privação do exercicio da profissão por tempo igual ao da condenação. 301: - Provocar aborto com anuencia e acordo da gestante -1 a 5 anos. § un. Em igualpena incorrerá a gestante que conseguir abortar voluntariamente, empregando para esse fim os meios; e com a redução da terça parte, se o crime fôr cometido para ocultar a deshonra própria. 302: Se o médico, ou parteira, praticando o aborto legal ou aborto necessario, para salvar a gestante de morte inevitavel, ocasionar-lhe a morte por impericia ou negligencia - 2 meses a 2 anos e privação do exercicio da profissão por tempo egual ao da condenação.

\section{SECÇÃo II}

\section{Das lesões}

Art. 318 - Causar dano, que não esteja previsto em outro dispositivo deste Código, ao corpo ou á saude de alguem.

Pena - detenção por 3 meses a um ano.

$\S 1^{\circ}$ - Se a lesão fôr culposa.

Pena - multa de 200\$000 a 2:000\$000.

§ 2.0 - Não será punivel, senão mediante queixa, a lesão produzida sem o emprego de arma ou substancia tóxica ou explosiva, que não incapacite o ofendido para as suas ocupações habituaes por mais de tres dias e dentro desse prazo se cure espontaneamente. Não se aplicará, todavia, este dispositivo, se a lesão fôr consequencia de qualquer dos atos especificados no art. 338.

Art. 319 - Se da lesão resultar :

I - incapacidade para as ocupações habituaes por mais de 30 dias;

II - perigo de vida;

III - enfraquecimento permanente de sentido, membro ort função ; 
IV - aceleração de parto.

Pena - reclusão por 1 a 5 anos.

$\S 10^{\circ}$ - Se a lesão fôr preterintencional.

Pena - detenção por 1 a 3 anos.

§ $20^{\circ}$ - Se a lesão fôr culposa.

Pena - detenção por 3 meses a 1 ano.

Art. 320 - Se da lesão resultar:

I - incapacidade permanente para o trabalho;

II - enfermidade certa ou provavelmente incuravel;

III - perda ou inhabilitação permanente de membro, sentido ou função.

IV - aborto.

$\nabla$ - deformidade permanente e aparente.

Pena - reclusão por 3 a 10 anos.

$\S 10^{\circ}$ - Se a lesão fôr preterintencional.

Pena - reclusão por 2 a 6 anos.

$\S 2 .^{\circ}$ - Se a lesão fôr culposa.

Pena - detenção por 1 a 3 anos.

Art. 321 - Se concorrer qualquer das circunstancias enumeradas no art. $311 \S \S 10^{\circ}$ e $2 .^{\circ}$ ou no mesmo artigo, $\S 3 .^{\circ} \mathrm{n} .^{\circ}$ II, as penas cominadas nos tres artigos precedentes para as lesões dolosas ou preterintencionaes serão respectivamente aumentadas ou diminuidas.

Pr. 182 - Aquele que lesar alguem na sua integridade corporea ou na saude será punido com detenção ou multa. Se responder por culpa, a detenção será no maximo até 30 dias. Não se procederá de oficio. 183: Será punido com prisão por 2 a 6 anos, ou, no caso de culpa com detenção, aquele que, lesando alguma pessoa na sua integridade corporea ou na saude: 1) lhe puser em perigo a vida; 2) lhe mutilar o corpo, num de seus membros ou orgãos importantes, ou sensivelmente enfraquecer esse orgão ou esse membro para a função que the é propria; 3) lhe causar enfermidade fisica ou mental provavelmente incuravel; 4) lhe causar incapacidade permanente de trabalho; 5) lhe causar deformidade grave e permanente, ou defeito fisico, que lhe altere a regularidade plástica, lhe destrua a beleza ou a incapacite para a arreira artistica que exercia ou nesta deprecie o valôr economico de seu trabalho; 6) provocar na ofendida o aborto ou lhe acelerar oparto. 184: - Aquele que tendo sob sua guarda ou custodia alguma pessôa, 
ou pertencendo a estabelecimento onde essa pessôa estiver internada, detida ou cumprindo pena, lhe inflingir castigos corporaes, será punido com detenção por 3 meses no minimo ou com prisão até 2 anos. A pena será a de lesão corporal grave, com aumento da sexta parte, quando semelhante lesão resultar dos castigos. 185: Em todos os casos previstos neste capitulo, em que se punir por culpa, a detenção será no minimo por 3 meses quando a culpa se originar da inobservancia: 1) das disposições regulamentares, que ao inculpado cumprisse especialmente guardar; 2) da tecnica consagrada de sua profissão, arte ou oficio; 3) dos deveres inherentes ao cargo, emprego ou profissão que exercer.

Cons. 303 - Ofender fisicamente alguem, produzindo-lhe dôr ou alguma lesão no corpo, embora sem derramamento de sangue -3 meses a 1 ano. 304: Se da lesão corporal resultar mutilação ou amputação, deformidade, ou privação permanente do uso de um orgão ou membro, ou qualquer enfermidade incuravel e que prive para sempre o ofendido de poder exercer o seu trabalho -2 a 6 anos. $\S$ un. Se produzir incômodo de modo que inhabilite o paciente do serviço ativo por mais de 30 dias, -1 a 4 anos. 305: Servir-se alguem, contra outrem, de instrumento aviltante, no intuito de causar-lhe dôr fisica e injuria-lo 2 a 3 anos. 306: Aquele, que, por imprudencia, negligencia ou impericia, na sua arte ou profissão, ou por inobservancia de alguma disposição regulamentar, cometer ou fôr causa involuntaria, direta ou indiretamente, de alguma lesão corporal - 15 dias a 6 meses.

Art. 322 - Transmitir a alguem, por meio de relações sexuaes ou atos de outra natureza, sífilis, blenorragia, ou outra molestia venerea de que saiba achar-se atacado.

Pena - detenção por 6 meses a 2 anos ou multa de um a 5 contos de réis, ou ambas cumulativamente.

$\S$ unico - Se o agente houver procedido intencionalmente.

Pena - reclusão por 1 a 5 anos e multa de 5 a 10:000\$000.

Pr. 180 - Qualquer pessôa que, ocultando estar contaminada, conseguir ter com outra contacto libidinoso, pelo qual lhe transmita sifilis, blenorragia ou qual doença venerea, será punida com detenção, por 6 meses no minimo, podendo a multa ser cumulada. Se o contagio tiver sido intencional, a pena será a de prisão até 3 anos.

Cons. Omissa. 


\section{SECQ̧̃̃̃o III}

\section{Da rixa}

Art. 323 - Participar de rixa, em que se envolvam mais de duas pessôas.

Pena - multa de $50 \$ 000$ a $500 \$ 000$.

$\S 10^{\circ}$ - Se da rixa resultar lesão, sem que se possa determinar quem a produziu.

Pena - para todos quantos hajam exercido atos de violencia contra o ofendido, detenção por 1 a 6 meses, se a lesão fôr leve; detenção por 6 meses a 3 anos, se fôr grave; e reclusão por 1 a 4 anos, se fôr gravissima.

$\S 20^{\circ}$ - Se da rixa resultar morte, sem que se possa determinar quem a causou.

Pena - para todos quantos hajam exercido atos de violencia contra o ofendido, reclusão por 2 a 6 anos.

Pr. 178 - Punir-se-á com detenção ou multa aquele que tomar parte em rixa, salvo se o fez para repelir ataque ou separar os contendores. A pena será de prisão até 5 anos quando a morte ou lesão corporal grave resultarem da rixa, ou quando em consequencia delas sobrevier a morte.

Cons. Omissa.

\section{SECÇão IV}

\section{Da periclitação da vida e da saude}

Art. 324 - Desafiar ou incitar alguem a bater-se em duelo; ou aceitar o desafio; ou ofender publicamente a quem não o fizer ou não o aceitar.

Pena - multa de 500\$000 a 5:000\$000.

$\S$ unico - Não será punivel o desafio a que se seguir o duelo.

Art. 325 - Bater-se em duelo.

Pena - detenção por 3 meses a 1 ano.

$\S 10^{\circ}$ - Se do duelo resultar lesão ou morte. 
Pena - as dos arts. $318 \S 5 .^{\circ}, 326,327$ e 328.

$\S 20^{\circ}$ - Ás testemunhas ou padrinhos do duelo aplicar-se-á diminuida a pena em que incorrerem os duelistas.

Pr. 175 - Será punido com multa aquele que: 1) desafiar alguem a bater-se em duelo, ou aceitar o desafio; 2) incitar alguem a bater-se em duelo com terceira pessôa; 3) como testemunha em duelo incitar os adversarios a baterem-se. Não será punivel o desafio a que se seguir o duelo. 176: Aqueles que se baterem armados em duelo serão punidos; 1) - com detenção até 3 meses, ou com multa, se não tiver havido derramamento de sangue ou deste resultar de lesão corporal leve; 2) com detenção por 1 a 6 meses, se resultar do duelo lesão corporal grave; 3) com detenção por 2 a 3 anos, se resultar a morte. 177: Aquele que estranho ao fato que tiver dado causa ao duelo, neste tomar parte como substituto de algum dos adversarios, será punido com detenção por 3 meses no minimo. Se o tiver feito por paga antecipada ou prometida, a pena de detenção, em que incorrer lhe será aplicada no dobro e convertida em prisão.

Cons. 307 - Desafiar outrem para duelo, ainda que o desafio não seja aceito $-100 \$$ a $200 \$$. § un. Se aquele que desafiar para o duelo fôr causa injusta do fato, que ocasionou o desafio - 15 dias a 2 meses. 305: Aceitar o desafio, ainda que tenha sido causa injusta do fato, que o determinou - $100 \$$ a 200\$. 309: Se o duelo tiver logar... 1) do que fizer uso das armas sem causar ao adversario nenhuma lesão corporal -15 dias a 2 meses. $\S 20^{\circ}$ - Se o culpado tiver sido causa injusta do duelo -1 a 4 meses. 310: Matar em duelo o adversario ou causar-lhe uma lesão corporal de que resulte a morte -1 a 4 anos. $\S 10^{\circ}$ Causar-lhe alguma lesão corporal das especificadas on art. $303-1$ a 3 meses. $\S 2 .^{\circ}$ Causar-lhe alguma lesão corporal das especificadas no art. $304-6$ meses a 1 ano. $\S 3 .^{\circ}$ A pena será diminuida da $6 .^{\mathrm{a}}$ parte se o culpado tiver sido induzido ao duelo por insulto ou ofensa grave. 311: Os causadores do desafio serão punidos com a multa de $100 \$$ a $200 \$$. $\S 10^{\circ}$ Com a mesma multa serão puniidos os padrinhos, se do duelo não resultar lesão corporal a qualquer dos combatentes. $\S 2 .^{\circ}-$ Se, porém, do duelo resultar a morte, ou lesão corporal, serão eles punidos como cumplices, segundo as regras geraes. 312: Quando alguem não tiver tomado parte no fato que motivou o duelo, apresentar-se para bater-se por algum dos combatentes, impor-sie-lhe-ão em dobro as penas em que incorrer. 313: Serão aplicadas ao homicidio e lesões corporaes resultantes do duelo, em vez das penas do art. 310 , as dos arts. $294 \S 2 .^{\circ}$ e 304, nos casos seguintes: 1) se as condições do combate não tiverem sido previamente combinadas pelos padrinhos; ou se o combate se travar sem que eles 
estivesse presentes; 2) se as armas usadas não forem iguaes; 3) - se na escolha das armas ou durante o combate, houver fraude ou viclação das condições estabelecidas; 4) se tiver sido expressamente convencionad,o ou resultar da especie do duelo, da distancia guardada entre os combatentes, ou outra condição estabelecida, que um deles deverá ficar morto; 5) se o duelo fôr provocado com o fim de lucro. 314: Ofender publicamente, ou expôr ao desprezo publico, a pessôa que não aceitar o duelo ou por esses meios provocar a aceita-lo - 6 meses a 1 anomulta de $100 \$$ a200\$.

Art. 326 - Disparar arma de fogo contra alguem, ou agredir alguem com arma de outra natureza, sem lhe causar dano ao corpo ou á saude, ou causando lesão que não incapacite o ofendido para as ocupações ordinarias por mais de 3 dias e seja curavel espontaneamente dentro desse prazo.

Pena - detenção por 3 meses a 1 ano.

$\S$ único - Aumentar-se-á ou diminuir-se-á a pena, se concorrer qualquer das circunstancias enumeradas no art. $318 \S \S 1 .^{\circ}$ e $2 .^{\circ}$ ou no mesmo artigo $\S 3 .^{\circ} \mathrm{n}$. II, respectivamente.

Pr. 179 - Aquele que, cientemente e sem escrupulo, crear perigo iminente de morte para alguem, será punido com detenção por ares meses no minimo ou com prisão até 2 anos.

Con. Omissa.

Art. 327 - Abandonar o agente pessôa confiada ao seu cuidado, guarda, vigilancia ou autoridade, e incapaz, por motivo de idade ou doença, de se defender ou de prover á propria subsistencia.

Pena - detenção por 1 a 3 anos.

$\S 10^{\circ}$ - Se do abandono resultar lesão grave ou gravíssima.

Pena - reclusão por 1 a 5 anos.

$\S 2 .^{\circ}$ - Se do abandono resultar a morte.

Pena - reclusão por 2 a 10 anos.

$\S 3 .^{\circ}$ - As penas cominadas neste artigo serão aumentadas:

I - se o abandono ocorrer em logar ermo;

II - se o crime fôr cometido por ascendente ou descendente, cônjuge, irmão, tutor ou curador, da pessôa abandonada.

Pr. 174 - Aquele que, a perigo de morte ou a grave e iminente perigo para a saude, expuser pessôa incapaz de defender-se, que tenha 
sob a sua guarda ou sobre a qual deva velar, ou que a abandonar quando correr perigo dessa natureza, será punido com detenção até 1 ano. A pena será de prisão até 5 anos, si a exposição ou do abandono resultar lesão corporal grave, e por 2 a 6 anos se resultar a morte. § un.: Verificadas as condições de parentesco e sigilio estabelecidas no art. 109, por ele regular-se-á a aplicação da pena, que será, porem, descontada de $2 / 3$, quando se tratar da propria mãe do exposto ou abandonado.

Cons. 292 - São tambem reputados crimes contra menores.. expôr a perigo de morte ou de grave e iminente dano á saude ou ao corpo, ou abandonar, ou deixar ao desamparo menor de idade inferior a 7 anos, que esteja submetido á sua autoridade, confiado á sua guarda ou entregue aos seus cuidados.. Se resultar a morte... As penas serão aumentadas de $1 / 3$ se 0 abandono ocorrer em logar ermo; se o crime fôr cometido pelos paes em dano dos filhos legitimos ou reconhecimentos ol legalmente declarados ou pelo adotante em dano do filho adotivo, ou pelo tutor em dano do pupilo.

Art. 328 - Expôr ou abandonar recem-nascido, para ocultar a deshonra própria ou de ascendente, descendente, conjuge ou irmã.

Pena - detenção por 3 a 6 meses.

$\S 10^{\circ}$ - Se da expcsição ou abandono resultar lesão grave ou gravíssima.

Pena - detenção por 6 meses a 1 ano.

$\S 20^{\circ}-$ Se resultar a morte.

Pena - detenção por 1 a 3 anos.

Pr. 174 (v. nota no art. precedente).

Cons. $292 \S 3 .^{\circ}-$ Quando o crime recaia sobre infante ainda não inscrito no registro civil, e dentro do prazo legal da inscrição, para salvar a honra própria ou mãe, ou descendente, ou filha adotiva ou irmã, a pena de 3 meses a 12 anos é reduzida de $1 / 3$ a $1 / 6$.

Art. 329 - Deixar de prestar assistencia, quando possa fazê-lo sem risco pessoal, ou de invocar imediatamente o socorro da autoridade publica, ao encontrar creança abandonada ou perdida, ou pessoa inválida ou ferida ao desamparo ou sob a ameaça de grave e iminente perigo.

Pena - detenção por 10 dias a 3 meses ou multa de $100 \$ 000$ a $2: 000 \$ 000$.

§ único - A pena será aumentada, se da omissão resultar lesão para a vítima, e dobrada se resultar a morte. 
Pr. 418 - (contravenção): Aquele que: 1) sem expôr a propria vida não acudir a quem estiver na iminencia de perdê-la; 2) não assistir a menor exposto ou abandonado, ou adulto inanido ou malferido que assim tiver encontrado, ou não levar o fato ao conhecimento da autoridade; 3) abandonar ao desamparo pessôa tue casualmente ferisse ou prostrasse, ou que o tenha sido por veículo ou animal de que se servia; 4) - impedir que alguem assista ou socorra a pessôa nas condições acima especificadas, ou lhe crear dificuldades ao cumprimento desse dever, será punido, nos casos dos $n^{\circ}$.s. 1 e 2 com detenção por 5 a 15 dias, e nos dos ns. 3 e 4 com detenção por 15 a 30 dia.

Cons. Omissa.

Art. 330 - Maltratar, de modo a pôr em perigo a saude ou a vida, pessôa da familia do agente, ou sujeita á sua autoridade, ou confiada á sua guarda ou vigilancia, por motivo de educação, ensino, tratamento ou custódia:

I - abusando dos meios de correção ou disciplina;

II - privando a vítima de alimentação e cuidados indispensaveis ;

III - obrigando-a a trabalhos excessivos ou inadequados.

Pena - detenção por 1 a 6 meses, ou multa de $200 \$ 000$ a 2:000\$000, ou ambas cumulativamente.

$\S 10^{\circ}$ - Se dos maus tratos resultar lesão grave ou gravissima.

Pena - reclusão por 1 a 4 anos.

$\S 20^{\circ}$ - Se deles resultar a morte.

Pena - reclusão por 4 a 10 anos.

Pr. 181 - Aquele que por interesse, egoismo ou maldade, abusando do seu poder ou ascendencia, ou da situação especial em que se encontre alguma pessôa, a submeta a um regime tal de trabalho que lhe faça perigar a saude, ou gravemente a prejudique, será punido com detenção até 6 meses, ou com multa, ou com ambas estas penas cumuladas. § un. Se do regime a que tiver sido submetido resultar, para a vitima, alguma das consequencias previstas no art. 45 (morte ou lesão grave, doença mental incuravel, inhabilitação permanente para o trabalho, perda de orgão, membro ou função, perda de um sentido ou da palavra) e o inculpado não podia prever, a pena será de prisão até 4 anos, e no caso de morte por 2 a 6 anos. 184: Aquele que, tendo sob sua guarda ou custodia alguma pessôa ou pertencendo a estabelecimento onde essa pessôa estiver internada, detida, ou cumprindo pena, lhe inflingir castigos 
corporaes, será punido com detenção até 3 meses, ou com prisão até 2 anos. A pena será a de lesão corporal grave, com aumento da sexta parte quando semelhante lesão resultar dos castigos.

Cons. 292. VI e s. - Aplicar castigos imoderados, abusando de meios de correção ou disciplina, a menor de 18 anos sujeito á sua autoridade ou que lhe foi confiado para crear, educar, instruir, ter sob a sua guarda ou a seus cuidados ou para o exercicio de uma profissão ou arte prisão de 3 meses a 1. ano. Dar a menor de 18 anos sujeito a seu poder, cargo, guarda ou cuidado, maus tratos habituaes, de maneira que prejudique sua saúde ou seu desenvolvimento inteletual - 3 meses a 1 ano. Privar voluntariamente de alimentos ou de cuidados indispensaveis ao ponto de lhe comprometer a saude, menor de 18 anos, sujeito a seu poder, ou confiado a seu cargo ou guarda ou cuidado, e que não esteja em condições de prover á sua propria manutenção -3 meses a 1 ano. Fatigar fisica ou intelectualmente com excesso de trabalho, por espirito de lucro ou por egoismo ou por deshumanidade, menor de 18 anos que lhe esteja subordinado como empregado, operario, aprendiz, domestico, aluno ou pensionista, de maneira que a saude do fatigado seja afetada ou gravemente comprometida - 3 meses a 1 ano. Nos casos dos ns. VI - IX, se os castigos imoderados, os maus tratos, a privação de alimentos ou de cuidados, o excesso ou fadiga causarem corporal grave ou comprometerem gravemente o desenvolvimento intelectual do menor e se o delinquente podia prever esse resultado, a pena será de 1 a 5 anos, e de 5 a 12 , se causarem a morte e o delinquente podia prevê-lo.

\section{Capitulo II}

\section{Dos crimes contra a honra}

Art. 331 - Injuriar alguem, ofendendo-lhe a dignidade ou pundonor.

$\S 10^{\circ}$ - Se a injuria consistir em violencia ou vias de fato, que, por sua natureza ou pelo meio empregado, sejam consideradas aviltantes.

Pena - detenção por 3 meses a 2 anos e multa de $500 \$ 000$ a 2:000\$000, além da pena cominada para a lesão que resultar da violencia.

$\S 2 .^{\circ}$ - Se a injuria fôr cometida de outra maneira.

Pena - detenção por 1 a 3 meses, ou multa de $200 \$ 000$ a $1: 000 \$ 000$. 
§3.॰ - Poderá o juiz conceder, conforme o caso, diminuição ou isenção da pena:

I - se as injurias forem recíprocas:

II - se, no momento do fato, o agente se encontrar em estado de violenta emoção, provocada por ato injusto de ôutrem.

Pr. 210 - Mediante queixa, será punido com detenção por 3 meses, no mínimo, e com multa, aquele que agravar pessôa a quem se dirija, na sua honra, reputação ou decôro, quer pessoalmente o faça, de viva voz, por vias do fato ou por gestos quer o faça, publicamente, de viva voz ou por escrito, quer o faça por bilheite, carta, cartão, telegrama ou desenho, que lhe remeta ou apresente. E' punivel a injuria contra os mortos. $\S$ un. Comete injuria aquele que, para humilhar alguem, lançar-lhe publicamente em rosto pena já cumprida ou fato compreendido na anistia ou indulto. 211: A injuria por vias de fato, caracterisa-se pelo fim exclusivo de injuriar, mas este se presume quando o gesto ou o instrumento, de que se tiver usado, forem por si mesmos aviltantes. Se das vias de fato resultar lesão corporal grave, proceder-se-á de oficio. 213: Poderá isentar da pena o injuriado, quando, por um procedimento repreensivel, tiver o ofendido diretamente provocado a injuria. 214: - A retorsão imediata, quando consistente noutra injuria, ou por vias de fato, autoriza o juiz a isentar da pena ambos os contendores ou sómente um deles, conforme as circunstancias.

Cons. 317 - Julgar-se-á injuria: a) a imputação de vicios ou defeitos, com ou sem fatos especificados, que possam expôr a pessôa ao odio ou ao despreso publico; b) a imputação de fatos ofensivos da reputação, do decôro e da honra; c) a palavra, o gesto ou sinal reputado insultante na opinião publica. 320: E' tambem injuria: $\S 10^{\circ}-$ usar de marca de fabrica ou comércio, contendo ofensa pessoal, ou vender ou expôr á venda, productos dela revestidos. § $2^{\circ}$ apregoar em logares publicos e vendas de gazetas, papeis impressos os manuscritos, de modo ofensivo a pessôa ou nacionalidade, certa e determinada, com o fim de escandalo e aleivosia.

Art. 332 - Caluniar alguem, imputando-lhe falsamente fato qualificado como crime.

Pena - detenção por 6 meses a 2 anos e multa de 1:000\$000 a $3: 000 \$ 000$.

$\S 10^{\circ}$ - Nas mesmas penas incorrerá quem propalar ou divulgar a calunia cometida por outrem.

§. 2. - A única prova admissivel da exceção de verdade será a certidão da sentença passada em julgado, que imputar o fato ao ofen- 
dido. Se pender ação contra este, pelo fato imputado, sobreestar-se-á, a requerimento do agente, na ação de calúnia, até que se julgue definitivamente a outra.

$\S 3 .^{\circ}$ - Poderá, todavia, ser feita de outra maneira a prova da exceção da verdade:

I - se o ofendido fôr agente ou depositario da autoridade pública e o crime imputado referir-se ao exercicio das respectivas funções :

II - se o permitir expressamente o ofendido, e o crime imputado não fôr daqueles, em que só mediante queixa ha logar a ação criminal.

$\S 4 .^{\circ}-\mathrm{A}$ notoriedade do fato não constituirá, em nenhuma hipotese, prova da verdade.

$\S 50^{\circ}-0$ querelado, que se retractar cabalmente da calúnia, no ato de ser proposta a ação criminal, ficará isento de pena. Responderá, entretanto, pelas custas, em que se incluem as despesas de publicação do termo de retractação, quando o querelante requerer que se lhe dê publicidade.

Pr. 205 - Será punido, mediante queixa, com detenção por 6 meses no minimo e com multa, aquele que, consciente da falsidade da imputação, ou de sua veracidade não mostrando a prova, embora a lei o permita, ou não a podendo ministrar, porque a lei o veda, dirigindo-se a terceiro, imputar a alguma pessôa fato que a exponha á ação do M. P. ou á desconsideração social. Propalar o fato equivale a imputa-lo. E' punivel a calunia contra os mortos. 206: - A prova, na exceção de verdades será sempre contraditoria, e não poderá o juiz, para julgar provada a exceção, basear-se na que não tiver sido submetida á apreciação do ofendido, nem substituir a judicial, quando a lei a veda, pela prova testemunhal. 207: A verdade da imputação de qualquer fato punivel mediante ação publica, não admite outra prova que a do caso julgado no juizo competente, e se nesta a ação respetiva estiver em curso, e o interessado o requerer, sobreestar-se-á na de calunia até que naquela o caso julgado se produza. § un. Da regra neste artigo estabelecida, quanto ao caso julgado excluem-se: 1) o caso em que se imputarem atos ou omissões contrarias aos deveres oficiaes ou forem eles imputados a corporações ov individuos revestidos de autoridade publica ou exercendo função publica; 2) - o caso em que o proprio ofendido requerer que a prova se faça por outro meio; 3 ) o caso em que provar o ofensor haver procurado, com a imputação, garantir interesse publico pelo qual lhe cumprisse legal- 
mente velar, ou exercer a legitima defesa de um seu direito privado relevante, que, sem ela inevitavelmente periclitaria. 208; Não se admitirá a prova da verdade: 1) quando o fato fôr imputado a qualquer das pessôas indicadas... 2) quando a proya depender de ação privada, e não se tiver dado queixa ou tiver sido retirada; 3) quando houver caso julgado, pelo mesmo fato absolvendo o ofendido; 4) - quando a imputação versar sobre fatos de sua vida familiar. § un. Não se poderá provar, mediante pericia medica, vexatoria ao ofendido ou a pessôa de sua familia, o fato imputado, nem poderá o juiz deferi-la. 209: A retratação inequivoca e cabal do ofensor em juizo, confessando, por termo nos autos, a falsidade da imputação, será, depois de pagas as custas, nestas computadas o necessario para a publicação do termo, homologada pelo juiz para, reconhecendo a calunia, excluir a pena, sem prejuizo do disposto no art. 32.

Cons. 315 - Constitue calúnia a falsa imputação feita a alguem de fato que a lei qualifica crime. § un. E' vedada a prova da verdade ou notoriedade do fato imputado á pessôa ofendida, salvo se esta: a) - fôr funccionario público ou corporação, compreendidos nesta disposição os senadores, deputados, conselheiros municipaes, intendentes ou prefeitos, e o fato imputado seguir-se ao exercicio de suas funções; b) permitir a prova; c) - tiver sido condenado pelo fato imputado. $\S$ un. Não se admitirá essa prova nos casos do art. $322 \S \S 3 .^{\circ}$ e $4 .^{\circ}$ (presidente da Republica, etc.).

Art. 333 - Difamar alguem, imputando-lhe, perante outrem, fato não criminoso, mas ofensivo á sua reputação.

Pena - detenção por 6 meses a 2 anos e multa de 1 a $3: 000 \$ 000$.

$\S 20^{\circ}$ - Não se admitirá a prova da verdade:

I - se a imputação versar sobre fato da vida conjugal ou familiar de alguem;

II - se a imputação envolver pessôa estranha ás partes, e ela não consentir expressamente que se faça a prova.

$\S 3 .^{\circ}$ - Aplica-se á difamação o disposto nos $\S \S 1 .^{\circ}, 4 .^{\circ}$ e $5 .^{\circ}$ do artigo precedente, com referencia á calúnia.

Pr. 205 - Pune como calúnia a imputação de fato que "exponha á desconsideração social", quando o agente se dirija "a terceiros", e não ministre a prova.

Cons. 317 - Pune como injuria "a imputação de fatos ofensivos da reputação, do decôro ou da honra". 
Art. 334 - Aumentar-se-ão as penas cominadas nos artigos precedentes, se qualquer dos crimes fôr cometido:

I - na presença de varias pessôas, ou pela imprensa, ou por outro meio que lhe facilite a divulgação;

II - mediante paga ou promessa de recompensa;

III - contra o Presidente da República, ou chefe ou membro de Governo estrangeiro em visita ao paiz, ou representante diplomático junto ao governo do Brasil.

IV - contra agente ou depositario da autoridade pública, em razão de suas funções.

Pr. $205-0$ mínimo da pena será respetivamente aumentado de $1 / 3$, ou $1 / 4$ e de $1 / 5$, quando o fato (calunioso) fôr imputado: 1) - ao presidente da República, ao chefe de nação estrangeira, ou membro de governo estrangeiro em caráter oficial no paiz, ou aos seus representantes acreditados perante o governo brasileiro; 2) ao presidente de um Estado da Federação; 3) a autoridade ou funcionario publico, em razão de cargo, oficio ou função. 215: Considerar-se-á como agravante da injuria: 1) tê-la infligido a ofensa a pessôa a quem devesse obediencia ou respeito; 2) tê-la infligido mediante vias de fato, a quem, por enfermidade ou velhice não se podia desforçar; 3) tê-la, infligido pela imprensa, ou por outro meio de facil divulgação oral ou escrita. 221: Aquele que tiver caluniado ou injuriado alguem por paga rcebida ou prometida, será punido com prisão até 3 anos e com multa.

Cons. 315 - Essas penas serão elevadas... se o crime fôr cometido cortra corporação que exercer autoridade publica ou contra agente ou depositario deste. 316: Se a calúnia fôr cometida por meio de publicação de panfleto, pasquim, alegoria, caricatura, ou qualquer papel escrito, impresso ou litografado distribuido por mais de 15 pessôas, ou afixado em lugar frequentado... 325: O criminoso, que houver paga ou promessa de recompensa, para cometer alguma injúria ou calúnia, incorrerá, além das penas respetivas, na multa do décuplo dos valores recebidos ou prometidos.

Art. 335 - Quando a ofensa fôr equivoca, poderá o ofendido pedir explicações em juizo. O que se recusar a dá-las ou não as der satisfatorias, a criterio do ofendido, responderá pela ofensa a que deu logar o equivoco. 
Pr. 220 - Quando as ofensas forem equivocas, é direito do ofendido exigir explicações em juizo, e o ofensor que as não der satisfatorias ou a elas recusar-se, ficará sujeito ás penas da ofensa resultante do equivoco.

Cons. 321 - Quando a injuria e a calúnia forem equivocas, poderá - ofendido pedir explicação em juizo. 0 que se recusar a dá-las, ou não as der satisfatoria, a juizo do ofendido, ficará sujeito ás penas da calúnia ou injúria, a que o equívoco der logar.

Art. 336 - Não constituem injuria, nem difamação puniveis criminalmente :

I - a ofensa irrogada em juizo pela parte ou seu procurador, uma vez que não seja dada á publicidade;

II - a opinião desfavoravel acerca de produção literaria, cientifica, artistica ou industrial, desde que não seja inequivoca a intenção de injuriar ou difamar.

Pr. 219 - As ofensas oraes ou escritas, irrogadas em juizo pelas proprias partes, ou seus procuradores e advogados, quando referentes á causa, serão reprimiveis com as sanções disciplinares previstas nas respetivas leis, regulamentos e regimentos; todavia, o juiz que encontrar ofensas em autos mandará riscá-las de modo a torná-las iligiveis, independentemente de requerimento do ofendido. $\S$ un. Quando a ofensa consistir em calúnia, é direito do caluniado impedir que ela se risque, e, fazendo extrair as peças necessarias, proceder criminalmente. 217: Nas disposições deste capitulo não se compreendem as opiniōes desfavoraveis da critica literaria, cientifica ou artistica, salvo quando inequivoca a intenção de calúnar ou injuriar; neste caso, porém, tratando-se de pessôa já falecida, nenhuma ação ou queixa será admissivel, decorridos 30 anos da morte.

Cons. 323 - Não tem logar ação criminal por ofensa irrogada em alegaçöes ou escritos produzidos em juizo. O juiz que encontrar calúnia ou injúrias, em alegações de autos, as mandará riscar, a requerimento da imporá ao autor uma multa de 20 a 50 : 


\title{
Capitulo III
}

\section{Dos crimes contra a liberdade individual}

\author{
SeçCão I \\ Dos crimes referentes á liberdade pessoal.
}

Art. 337 - Reduzir alguem a condição analoga á escravidão.

Pena - reclusão por 2 a 10 anos.

Por. - omisso.

Cons.

Art. 338. - Privar alguem de sua liberdade, mediante sequestro ou cárcere privado, por tempo não maior de 24 horas.

Pena - detenção por 3 meses a 1 ano.

$\S 10^{\circ}$ - Se a privação da liberdade perdurar por mais de 24 horas e menos de 15 dias.

Pena - detenção por 1 a 3 anos.

§ 2. - A pena será de reclusão por 2 a 8 anos:

I - se a privação da liberdade perdurar por mais de 15 dias;

II - se o agente cometer o crime:

a) contra seu ascendente, descendente ou cônjuge;

b) para fim libidinoso, ou com o fito de lucro, ou por outro motivo torpe;

c) mediante a internação do ofendido em manicômio, dolosamente promovida;

d) sob o falso pretexto de determinação de autoridade publıca;

III — se do crime resultar :

a) grave dano para a saude ou patrimonio do ofendido;

b) grande sofrimento para o ofendido, em razão do logar ou natureza da detenção, ou de atos de crueldade. 
Pr. 226 - Aquele que ilegalmente privar alguem de sua liberdade será punido com detenção. A pena será a de prisão até 5 anos: 1) - se o criminoso tiver sequestrado uma pessôa para dela abusar e entrega-la á prostituição ou por meio dela obter vantegem pecuniaria; 2) - se a tiver sequestrado ou feito sequestrar, sob o falso pretexto de tratar-se de doente mental; 3) - se durante a sequestração a tiver maltrado, ou, em consequencia dela a saude da vitima se alterar de modo a fazer-lhe perigar a vida; 4) - se a pessôa sequestrada fôr ascendente, descendente ou cônjuge do sequestrante; 5) — se tiver a sequestração durado mais de 1 mês.

Cons. 181 - Privar alguma pessôa de sua liberdade, retendo-a por si ou por outrem, em cárcere privado, ou conservando-a em sequestro por tempo menor de 24 horas -2 meses a ano. $\S 10^{\circ}-$ Se a retenção exceder desse prazo - 6 mezes a 2 anos. $\$ 20^{\circ}$ - Se o criminoso cometer o crime simulando ser autoridade publica ou usando de violencia - a mesma com aumento da terça parte. $\S 3 .^{\circ}-E^{\prime}$ crime de carcere privado não mostrar que restituiu o paciente á liberdade ou indicar o seu paradeiro - 2 a 12 anos.

Art. 339 - Punir-se-á com detenção por 1 mês a 1 ano 0 funcionario publico:

I - que, sem as formalidades legaes ou com abuso do poder, ordenar ou efetuar medida privativa ou restritiva da liberdade individual;

II - que, sem ordem escrita de autoridade competente:

a) receber e recolher alguem á prisão, a não ser no caso de flagrante delito;

b) receber e recolher alguem a estabelecimento destinado á execução de pena detentiva ou medida de segurança;

III - que indebitamente prolongar a execução de pena on medida de segurança, deixando de expedir oportunamente ou de executar incontinenti a ordem de soltura;

IV - que submeter alguem que, embora provisoriamente, esteja confiad́o á sua guarda ou custódia, a vexame ou a medida não autorizada por disposição legal ou regulamentar;

$\nabla$ - que, com abuso do poder, efetuar busca ou outra diligencia.

$\S$ unico - Na mesma pena incorrerá o diretor de manicômio particular, ou quem suas vezes fizer: 
I - que, salvo o caso de urgencia, receber e internar como alienada uma pessôa, sem autorização do curador ou ordem do juiz competente;

II - que, dentro de 48 horas, não comunicar á autoridade competente a internação efetuada, por urgente, sem as formalidades legaes.

Prr. 231 - O funcionario público, preposto á direção ou vigilancia do estabelecimento onde se cumpram penas, ou se executem medidas de segurança, ou se detenham indiciados, que nele receber e detiver alguem, sem ordem escrita da autoridade judiciaria, será punido com detenção até 3 meses ou com multa, e com qualquer destas penas a interdição relativa. § un. - Neste artigo não se compreendem o scasos de flagrante delito, os em que a prisão é legal antes de formada a culpa, ou algum internado, detido ou sentenciado; 1) - não o puser imediatamente juiz. 232: O funcionario publico que, respondendo pela custodia de algum internado, detido ou setenciado; 1) - não o puser imediatamente em liberdade, quando o tiver ordenado juiz competente; 2) - protrair a execução de alguma pena ou medida de segurança, será punido com detenção por 3 a 9 meses, mais a interdição relativa. § un. Quando para cometer o crime, tiver cedido o funcionario á imposição de superior hierárquico, ficará este sujeito ás mesmas penas.

Cons. Omissa.

Art. 340 - Impedir alguem de praticar ato licito, ou constranger alguem a fazer ou tolerar cousa a que a lei não o obrigue.

Pena - detenção por 1 a 6 meses ou multa de 500\$000 a $2: 000 \$ 000$.

$\S$ único - Se o agente usar de violencia ou ameaça.

Pena - detenção por 6 meses a 2 anos, alem da pena em que o agente incorrer pelos atos de violencia.

Pr. 223 - Aquele que, usando de violencia ou de ameaça grave para com alguma pessôa, ou depois de, por qualquer outro modo, lhe haver tolhido a capacidade de resistir, constranger a praticar, não praticar ou a deixar que se pratique algum ato, será punido com detenção até 6 meses, ou com prisão por 6 meses a 2 anos. A pena será a de prisão por 1 a 3 anos, quando, para que o crime se cometesse, algumas péssôas anônimos, avisos sibbólicos, ou á força intimidativa de associações sese tiverem reunido, ou se tiver recorrido a armas, disfarces, escritos creta, reaes ou imaginarias. § un. $\mathrm{Na}$ disposição deste artigo, não 
se compreende a intervenção médica ou cirurgica, á revelia do paciente ou de seu representante legal, quando justificada por iminente perigo de vida.

Cons. 180: Privar alguem de sua liberdade pessoal, já impedindo de fazer o que a lei permite, já obrigando a fazer o que ela não manda - 1 a 6 meses. § un. Se para esse fim empregar violencia ou ameaças - a mesma com o aumento da terça parte, além das mais em que incorrer pelos atos de violencia.

Art. 341 - Ameaçar alguem de dano injusto á sua pessôa, ou a pessôa de sua familia, ou a seu patrimonio.

Pena - detenção por 1 a 6 mezes, ou multa de $200 \$ 000$ a $2: 000 \$ 000$, ou ambas cumulativamente.

§ único - Sómente haverá logar a ação criminal mediante queixa.

Pr. 225 - Aquele que alarmar ou aterrar alguem com a ameaça dede causar-lhe injusto dano, ou de causá-lo a pessôa de sua familia, será punido, mediante representação, com detenção e multa. Quando a ameaça tiver sido feita por meio de simbolos de associação perigosa e secreta, ou o seu autor a tiver feito como filiado a quadrilha ou bando, ou por quaesquer outras circunstancia se revelar particularmente perigoso, a pena será a de prisão por 6 mezes a 2 anos e se procederá de oficio.

Cons. 184 - Prometer ou protestar, por escrito assinado ou anônimo, ou verbalmente fazer a alguem um mal que constitue crime, impondo, ou não, qualquer condição ou ordem -1 a 3 meses. $\S$ un. Se o crime fôr cometido contra corporação, a pena será aplicada com aumento da terça parte.

Art. 342 - Privar, alguem, transitoriamente, da consciencia e da vontade, mediante sugestão hipnótica, ou não, narcose, embriaguez pelo alcool ou substancia de efeitos análogos, ou outro meio:

$\S 10^{\circ}$ - Se o crime fôr cometido com o consentimento do paciente.

Pena - multa de 200\$000 a 1:000\$000.

$\S 2 .^{\circ}$ - Se o crime fôr cometido com o consentimento do paciente, ou se este fôr incapaz de prestá-lo, por ser menor de 18 anos ou alienado, ou se o consentimento fôr obtido mediante violencia ou fraude.

Pena - detenção por 3 meses a 1 ano ou multa de $500 \$ 000$ a $2: 000 \$ 000$. 
$\S 3 .^{\circ}-$ Se o agente houver procedido com o intuito de facilitar a pratica de um crime, ou se algum crime fôr cometido em tal estado pelo paciente.

Pena - reclusão por 1 a 5 anos.

$\S 4 .^{\circ}$ - Excluem-se deste dispositivo a hipnose e a narcose feitos por profissional habilitado, para fim terapeutico ou científico.

Pr. Omisso.

Cons.

\section{SECÇÃo II \\ Dos crimes contra a inviolabilidade do domicilio}

Art. 343 - Entrar na casa alheia, ou em suas dependencias, sem o consentimento do morador; ou, contra a vontade expressa deste, ali permanecer.

Pena - detenção por 1 a 3 meses ou multa de 200\$000 a $1: 000 \$ 000$.

$\S 10^{\circ}$ - Se o crime fôr cometido durante a noite, ou em despovoado, ou com o emprego de violencia ou de armas, ou por duas ou mais pessôas.

Pena - detenção por 6 meses a 2 anos, além da cominada para $o$ ato de violencia.

$\S 2 .^{\circ}$ - Se a entrada ou permanencia na casa alheia, sem o consentimento, ou contra a vontade expressa do morador, fôr cometida por funcionario público, fóra dos casos legaes ou com inobservancia das formalidades estabelecidas na lei, ou com abuso do poder.

Pena - detenção por 6 meses a 2 anos.

$\S 3 .^{\circ}$ - Não constitue crime a entrada ou permanencia em casa alheia ou suas dependencias:

I - durante o dia, para efetuar prisão ou outra diligencia judicial, com observancia das formalidades legaes;

II - a qualquer hora do dia ou da noite, para cumprir dever de humanidade, ou evitar grave dano a si próprio ou a terceiro, ou prestar auxilio á autoridade pública.

$\S 4 .^{\circ}-\mathrm{Na}$ expressão "casa alheia" não se compreendem: 
I - as hospedarias, estalagens e outras semelhantes, enquanto abertas;

II - as tavernas, casas de jogo e outras semelhantes, que embora funcionem de portas fechadas, sempre se consideram accessiveis á autoridade pública.

$\S 5 .^{\circ}$ - Só mediante queixa se procederá no caso da cabeça do artigo.

Pr. 233 - Mediante representação será punido com detenção ou multa aquele que: 1) entrar em casa alheia, ou nas suas dependencias, sem que o consinta o morador, o permita a lei ou se observem as formalidades nela prescritas; 2) tendo entrado na casa alheia com o consentimento do morador, nela permanecer contra a vontade de mesmo; 3) clandestina ou insidiosamente se introduzir na casa alheia. $\S 10^{\circ} \mathbf{A}$ pena será de prisão por 6 meses a 2 anos, e se procederá de oficio, quando a entrada se realizar durante a noite, ou com violencia, com armas, ou com o concurso de duas ou mais pessôas. § $2 .^{\circ}-$ Nenhuma pena se aplicará aquele que: 1) tiver entrado na casa alheia para acudir a vítima de crimes ou desastres, ou para impedi-los, quando iminentes; 2) tiver entrado de dia na casa alheia, com observancia das formalidades legaes, para prender criminosos, ou efetuar diligencias necessarias á justiça. 234: O funcionario público que com usurpação ou abuso do poder, ou fóra dos limites de sua competencia, ou dos casos previstos em lei, ou nestes não observadas as formalidades nela prescritas, entrar na casa alheia contra a vontade do morador, será punido com detenção por 3 mezes a 2 anos, e, em ambos os casos, com interdição relativa. 235: $\mathrm{Na}$ expressão - casa alheia - compreende-se a construção estavel ou movel, destinado ao repouso noturno da pessôa, e, bem assim, numa casa de habitação coletiva os aposentos ocupados, e num edificio o compartimento em que alguem exercite sua profissão ou atividade. 236: $\mathrm{Na}$ expressão - casa alheia - não se compreendem: 1) as casas de habitação coletiva, como hoteis, hospedarias, e estalagens, quando abertas, salvo a restrição do art. precedente; 2) as casas de jogo e as tabernas, que se considerarão sempre abertas ás autoridades, embora funcionem de portas fechadas.

Cons. 196: Entrar á noite na casa alheia, ou em quaesquer de suas dependencias, sem licença de quem nela morar -2 a 6 meses. $\S$ un. o crime fôr cometido contra corporação, a pena será aplicada com audo-se de armas, ou por 2 ou mais pessôas que se tenham ajuntado para aquele fim - 3 meses a 1 ano, além daquelas que incorrer pela violencia. 197: E' permitida a entrada á noite em casa alheia: 1) no caso de incendio; 2) no de iminente e imediata ruina; 3) no de inundação; 
4) no de ser pedido socorro; 5) no de se estar ali cometendo algum crime ou violencia contra alguem. 198: Entrar de dia em casa alheia, fóra dos casos permitidos e sem as formalidades legaes; introduzir-se nela furtivamente ou persistir em ficar contra a vontade de quem nela morar - 1 a 3 meses. 199: A entrada de dia em casa alheia é permitida: 1) nos mesmos casos em que é permitida á noite; 2) naqueles em que, de conformidade com as leis, se tiver de proceder á prisão de criminosos, á busca ou aprensão de objetos havidos por meios criminosos, á investigação dos instrumentos ou vestigios do crime ou de contrabando, á penhora ou sequestro de bens que se ocultarem; 3) no de flagrante delito ou em seguimento de réo achado em flagrante. 200: Nos casos mencionados no $\S 20^{\circ}$ do art. antecedente se guardarão as seguintes formalidades: $1^{\circ}$ ) ordem escrita de autoridade que determinar a entrada na casa; $\left.2 .^{\circ}\right)$ assistencia de escrivão ou qualquer oficial de justiça com duas testemunhas. 201: Se o oficial público, encaregado da diligencia, executá-la sem executar as formalidades prescritas, desrespeitando o recato ou o decoro da familia, ou faltando á devida atenção aos moradores da casa - 1 a 2 meses e multa de 50\$ a 100000. 202: Da diligencia se lavrará auto assinado pelos encarregados da mesma e pelas testemunhas. 203: As disposições sobre a entrada na casa do cidadão não se aplicam ás estalagens, hospedarias, tavernas, casas de tavolagem e outras semelhantes, emquanto estiverem abertas.

\section{SECÇão III}

\section{Dos crimes contra a inviolabilidade da correspondencia}

Art. 344 - Tomar indebitamente conhecimento do conteúdo de correspondencia fechada, que seja dirigida a outrem.

Pena - detenção por 1 a 6 meses e multa de 200\$ a 1:000\$000.

$\S 10^{\circ}-\mathrm{Na}$ mesma pena incorrerá :

I - quem se apossar indebitamente de correspondencia alheia, ainda que não fechada, sonegando-a, alterando-a ou destruindo-a, no todo ou em parte;

II - quem fraudulentamente tomar conhecimento de comunicação telegráfica dirigida a outrem, ou de conversação telefonica entre outras pessôas, ou interrompe-las, ou impedi-las.

$\S 20^{\circ}$ - Aumentar-se-á a pena, se o agente causar dano a alguem, com a prática de algum dos crimes definidos no $\S 10^{\circ}$ 
deste artigo, ou com a revelação total ou parcial do conteúdo da correspondencia de que indebitamente houver tomado conhecimento.

$\S 3 .^{\circ}$ - A pena será de 1 a 3 anos de detenção ou reclusão, se o agente cometer algum dos crimes definidos neste artigo, com abuso da função, que desempenhar, em serviço postal, telegráfico ou telefônico, ou mediante ameaça ou violencia contra pessoa.

$\S 4 .^{\circ}$ - Proceder-se-á de oficio no caso do $\S 3 .^{\circ}$; e mediante queixa nos outros.

Pr. 237 - Aquele que por qualquer meio, devassar o conteúdo da correspondencia fechada dirigida a outrem que the tenha vindo acidentalmente ás mãos, será punido, mediante representação, com multa ou com detenção até 6 meses. Esta será o mínimo da pena e o seu máximo o genérico, mais a multa, quando, com o devassamento da correspondencia, ou com a revelação do seu conteudo, vier alguem a sofrer relevante prejuizo moral ou material. 238: Aquele que se apossar da correspondencia alheia seá punido, mediante representação, com multa, ou com detenção até 6 meses. Proceder-se-á de oficio, e se punirá o infrator com detenção por 6 meses, no mínimo, ou com prisão por 6 a 2 anos, quando, para se apossar da correspondencia, tiver ele recorrido á violencia ou a ameaça, ou tiver previamente reduzido o seu portador ou detentor á impossibilidade de resistir-lhe. 239: Aquele que, sem lhe devassar o conteudo, sonegar, suprimir ou destruir, embóra parcialmente, a correspondencia alheia que, por qualquer modo, lhe tenha vindo ás mãos, será punido, mediante representação, com multa ou com detenção até 6 meses. Se da infração resultar para alguem relevante prejuizo material ou moral, a alinea do art. 238 será aplicavel. 240: Aquele que abusando da condição de socio, interessado, empregado ou preposto em estabelecimento comercial ou industrial, lhe desviar, sonegar, subtrair, suprimir ou destruir, no todo ou em parte, a correspondencia, ou a estranhos revelar-lhe o conteudo, será punido, mediante representação, com detenção por 3 meses no mínimo ou com prisão até 2 anos. 243: $\mathrm{Na}$ palavra "correspondencia", tanto se compreende a epistolar, com a telegráfica, a radiográfia e a telefônica, quando reduzidas a escrito para a sua transmissão ao destinatario.

Cons. 189 - Abrir maliciosamente carta, telegrama ou papel fechado endereçado a outrem, apossar-se de correspondencia epistolar ou telegráfica alheia, ainda que não esteja fechada e que por qualquer meio lhe venha ás mãos; tirá-la de repartição pública ou do poder do portador particular para conhecer-lhe o conteúdo -1 a 7 meses. § un. No caso de ser revelado no todo ou em parte o segredo da correspondencia violada, a pena será aumentada de 1/3. 190: Suprimir correspon- 
dencia epistolar ou telegráfica endereçada a outrem - 1 a 6 meses. 192: § $1 .^{\circ}$ Nas mesmas penas (1 a 3 meses e suspensão de oficio, emprego ou profissão por 6 meses a 1 ano) incorrerá o empregado do correio que se apoderar de carta não fechada, ou abrí-la, se fechada, para conhecer-lhe o conteúdo, ou comunica-lo a alguem, e bem assim o do telégrafo que para fim idêntico, violar telegrama ou propagar a comunicação nele contida. $\S 2 .^{\circ}$ Se os empregados suprimirem ou extraviarem a correspondencia ou não a entregarem ou comunicarem ao destinatario - 1 a 6 meses e perda do emprego. 195: São tambem crimes contra a inviolabilidade dos segredos:... a) reproduzirem, comunicarem ou divulgarem de qualquer forma ou utilizarem para qualquer fim as correspondencias radio-elétricas que interceptarem ou captarem... violarem o sigilo das correspondencias radio-elétricas ou que tiverem ca nhecimento em razão do cargo ou do oficio.

\section{SECÇÃo IV}

\section{Dos crimes contra a inviolabilidade dos segredos}

Art. 345 - Dar á publicidade documento particular ou correspondencia confidenciaes, de que o agente seja destinatario ou detentor, e cuja publicação cause ou possa causar dano a alguem.

Pena - detenção por 1 a 6 meses ou multa de $200 \$ 000$ a $2: 000 \$ 000$.

$\S$ único - Não se procederá senão mediante queixa.

Pr. 241 - 0 destinatario, que sem permissão do autor da correspondencia, seus herdeiros ou cônjuge sobrevivo, lhe publicar o conteúdo de natureza intima ou cujo sigilo lhe tenha sido recomendado, ou que diretamente concorrer para que alguem o publique, será punido, mediante representação, com detenção até 6 meses e com multa. Este artigo é aplicavel a todos aquele que tiver acidentalmente em seu poder papeis ou documentos particulares de outrem. 242: Não se tratando de correspondencia, papeis ou documentos de natureza intima $\theta$ confidencial e cujo sigilo tenha sido recomendado, não se punirá a publicação ou a revelação das quaes nenhum dano possa resultar.

Cons. 191 - Publicar o destinatario de uma carta, ou correspondencia, sem consentimento da pessôa que a endereçou, o conteúdo, não sendo em defesa de direitos, e de uma ou outra resultando dano ao rmetente - 2 a 4 meses. 193: A autoridade que, de posse de carta ou correspondencia particular, utilizá-la para qualquer intuito, seja embóra o da descoberta de um crime ou prova deste, incorrerá na perda do emprego: 
e na multa de $100 \$$ a $500 \$ 000$. 194: As cartas obtidas por meios criminosos não serão admitidas em juizo.

Art. 346 - Revelar segredo, de que tiver ciencia em razão de ministério, oficio, ou profissão, uma vez que da revelação advenha ou possa advir dano para alguem.

Pena - detenção por 3 meses a 1 ano ou multa de 1 a $10: 000 \$ 000$.

$\S 1^{\circ}$ - Não será punivel a revelação, quando feita como recurso extremo para evitar outro mal de maior gravidade.

$\S 2 .^{\circ}$ - Só mediante queixa se procederá.

Pr. 244 - Aquele que sem justa causa revelar segredo de natureza privada, do qual tiver tido comunicação ou noticia, em razão do proprio estado, ou da profissão, arte, oficio, cargo ou munus publico que exerer, será punido, mediante representação com detenção até 6 meses ou com multa. A justa causa sómente excusará quando se tiver limitado a revelação ao minimo indispensavel, para que se evitasse o mal maior previsivel no sigilo.

Cons. 192 - Revelar qualquer pessôa o segredo de que tiver noticia, ou conhecimento, em razão de oficio, emprego ou profissão.

Art. 347 - Revelar ou aproveitar, em beneficio alheio ou próprio, esclarecimento destinado a ficar secreto, com referencia a invenção cientifica ou de aplicação industrial, de que tenha conhecimento o agente, em razão de ministerio, oficio ou profissão.

Pena - detenção por 6 meses a 2 anos e multa de 1:000\$000 a $15: 000 \$ 000$.

$\S 1 .^{\circ}$ - As penas serão :

I - aumentadas, se a revelação tiver sido feita a estrangeiro;

II - dobradas, substituida a detenção pela reclusão, se a revelação feita a estrangeiro fôr de segredo que interesse á defesa nacional.

$\S 20^{\circ}$ - Proceder-se-á de oficio no caso $\S 1 .^{\circ} \mathrm{n}$. II, e nos outros mediante queixa.

Pr. - Omisso.

Cons. - 
TITULO XI

\title{
Dos crimes contra a propriedade imaterial
}

\author{
Capitulo I

\section{Dos crimes referentes á propriedade literaria cientifica e artistica}

Art. 348 - Punir-se-á, mediante queixa, com detenção por 3 meses a 1 ano ou multa de 1 a 5:000\$ aquele que violar direito de autor de obra literaria, científica ou artistica, nos termos em que é definido pela lei civil.

$\S$ único - Da mesma forma se procederá contra aquele que importar, vender, ou expuser á venda, ocultar, ou tiver em depósito, obra contrafeita.

Pr. Omisso.

Cons. 342 - Os direitos de autor de qualquer obra literaria, científica ou artistica consistem na faculdade, que só ele tem, de reproduzir ou autorizar a reprodução de seu trabalho pela publicação, tradução, representação, execução ou de qualquer outro modo. A lei garante esses direitos aos nacionaes e estrangeiros residentes no Brasil, desde que preencham as condições nela estabelecidas. $\S 10^{\circ}$ Todo atentado doloso ou fraudulento contra os direitos de autor constitue crime de contrafação. Os que cientemente venderem, exporem á venda, tiver em seus estabelecimentos para serem vendidos ou introduzem no territorio da República, com fim comercial, objétos contrafeitos são culpados do mesmo crime. § 2..$^{\circ}$ Nos crimes de contrafação os cúmplices são punidos com penas iguaes ás dos autores. § $3 .^{\circ}$ Consideram-se igualmente contrafações: 1) as traduções em lingua portuguesa de obras estrangeiras quando não autorizadas expressamente pelo autor e feitas por estrangeiros não domiciliados na República ou que nela não tenham sido impressas. As traduções autorisadas que estiverem nessas condições devem ter a menção expressa: "Tradução autorizada pelo autor", únicas que podem ser introduzidas, vendidas ou representadas no território da República. 2) As reproduções, traduções, execuções ou representações, quer tenham sido autorizadas, quer não o tenham sido, por se tratar de obras que não gosam de proteção legal ou já caídas do dominio público, em que se fizeram 
alterações, acréscimos ou supressões sem o formal consentimento do autor. $\S 40^{\circ}$ Não se consideram contrafação as reproduções enumeradas no art. 666 do Cod. Civ. $\S 5 .^{\circ}$ O crime de contrafação será punido, não só com as penas estabelecidas no art. 345, como tambem com o confisco dos objétos contrafeitos e todos os moldes, matrizes e quaesquer utensilios que tenham servido para a contrafação, além da indenização das perdas e danos causados ao autor da obra contrafeita. $\S 6 .^{\circ}$ No caso de representação ou exibição não autorisada das obras dramáticas, ou musicais, o autor ou concessionario poderá requerer a apreensão das receitas brutas da representação ou exibição, e o empresario reconhecido culpado será punido com prisão celular por 6 meses a 1 ano. A importancia da indenisação não será inferior a $50 \%$ das receitas brutas. § 7. Qualquer dos collaboradores de uma obra artistica, literaria ou científica pode, independente dos demais, usar do seu direito para a punição dos culpados. 343: Nenhuma composição musical, tragedia ,drama, comédia, ou qualquer outra produção, seja qual fôr a sua denominação, poderá ser executada ou representada em teatros ou espetáculos públicos, para os quaes se pague entrada, sem autorisação, para cada vez, do seu autor, representante ou pessôa legitimamente subrogada nos direitos daquele. 344: Reimprimir, gravar, litografar, importar, introduzir, vender documentos, estampas, cartas, mapas e quaesquer publicaçōes feitas por conta da Nação ou dos Estados em oficinas particulares ou publicas - apreensão e perda para a Nação multa igual ao triplo do valor. $\S$ un. $O$ privilegio da Fazenda Pública resultante deste art. não importa proíbição de transcrever ou inserir qualquer dos atos acima indicados nos periódicos e gazetas em compêndios, tratados ou quaesquer obras cientificas e literarias nem a de revender os objétos especificados, tendo sido legalmente adquiridos. 345: Reproduzir sem consentimento do autor qualquer obra literaria ou artistica, por meio da imprensa, gravura ou litografia ou qualquer processo mecânico ou químico, emquanto viver, ou a pessôa a quem houver transferido a sua propriedade, e até 60 anos depois de sua morte, sem consentimento de seus herdeiros e sucessores - apreensão, pena e multa igual ao triplo ... a favor do autor. 347: Traduzir e expôr á venda qualquer escrito ou obra sem licença de seu autor - apreensão, perda, multa a favor do autor. Esta proíbição não implica a de fazer citação parcial de qualquer escrito, polêmica ou ensino. 349: Importar, vender, ocultar ou receber para serem vendidas obras literarias ou artisticas, sabendo que são contrafeitas - apreensão, perda, multa a favor do dono ou autor. 350: Reproduzir qualquer produção artistica, sem consentimento do dono, por imitação ou contrafação - as do art. precedente.

Art. 349 - Punir-se-á, mediante queixa, com detenção por 6 meses a 2 anos e multa de 1 a $5: 000 \$$ aquele que aplicar nome ou 
pseudônimo ou sinal adotado por alguem para designar seus trabalhos literarios, cientificos ou artisticos, em obra que não seja da autoria dêle.

Pena - detenção por 6 meses a 2 anos e multa de 1 a $5: 000 \$ 000$.

Pr. Omisso.

Cons. 346 - A aplicação fraudulenta ou de má fé sobre uma obra literaria, científica ou artistica, do nome de um autor ou de qualquer sinal por ele adotado para designar suas obras, será punida ...6 meses a 1 ano, multa de 500\$ a 1:000\$000, sendo tambem a obra apreendida.

\section{Capítulo II}

\section{Dos crimes referentes ás patentes de invenção}

Art. 350 - Violar direito decorrente de privilegio de invenção e descoberta:

I - fabricando, sem licença do concessionario ou cessionario, produto que fôr objeto do privilegio concedido;

II - empregando meio ou fazendo aplicação que fôrem objeto do privilegio;

III - importando, vendendo, expondo á venda, ou ocultando ou recebendo para o fim de ser vendido produto, que saiba ser contrafeito, de industria privilegiada.

Pena - detenção por 3 meses a 1 ano e multa de 1 a 15:000\$000.

$\S 10^{\circ}$ - Aumentar-se-á a pena :

I - se o agente fôr ou tiver sido mandatario, preposto ou empregado no estabelecimento do concessionario ou cessionario da patente;

II - se o agente se tiver associado a mandatario, preposto ou empregado do concessionario ou cessionario, para conhecer o modo de obter ou empregar a invenção.

$\S 2 .^{\circ}$ - A sentença condenatoria terá como efeito a adjudicação do produto e dos aparelhos e instrumentos empregados na fabricação, ao concessionario ou cessionario da patente. 
§3. - Não haverá solidariedade entre os agentes pela reparação do dano; salvo se o crime consistir em fato unico, praticado coletivamente. Não haverá tambem acumulação de penas por infrações reiteradas antes de iniciado o procedimento criminal.

$\S 4 .^{\circ}$ - Os crimes definidos neste dispositivo serão punidos mediante queixa.

Pr. Omisso.

Cons. 351: Identica, sendo, porém, a pena de multa de 500\$ a 5:000\$000.

Art. 351 - Serão punidos com multa de 500\$000 a 5:000\$000 :

I - que aquele que falsamente se inculcar possuidor de patente, usando, em produto ou objeto preparado para o comercio ou exposto á venda, de marca, emblema, letreiro ou rotulo indicativos de privilegio;

II - o inventor que, estando a patente anulada, caduca ou suspensa, continuar a exercer a industria como privilegiada;

III - o inventor privilegiado que, em prospecto, letreiro anuncio ou qualquer meio de publicidade, fizer menção da patente, sem designar o objeto especial para que a houver obtido.

$\S$ unico - Aplicar-se-á no caso deste artigo o disposto na ultima parte do $\S 3 .^{\circ}$ do artigo precedente.

Pro. Omisso.

Cons. 352: identica, sendo, porém, a multa de $100 \$$ a $500 \$ 000$.

Art. 352 - Punir-se-á mediante queixa, com multa de 500\$a 5:000\$000 aquele que:

I - reproduzir, por qualquer meio, no todo ou em parte, sem licença do dono, desenho ou modelo patenteado;

II - reproduzir, no todo ou em parte, os carateristicos reivindicados de desenho ou modelo patenteado, para que outrem o explore;

III - explorar, sem a autorisação devida, desenho ou modelo patenteado de outrem; 
IV - vender, expuzer á venda- ou introduzir no país, maliciosamente, objeto que seja imitação ou cópia de modelo patenteado.

$\S$ unico - Punir-se-á com multa de 500\$000 a 1:000\$000 quem usar indebitamente, em modelo ou desenho, da palavra "deposito", por extenso ou em abreviatura; ou mencionar, em anúncio ou papel comercial, como depositado, desenho ou modelo, que não o fôr.

Pro. Omisso.

Decr. 24507, de 29-VI-34: identico.

\section{Capítulo III}

\section{Dos crimes referentes ás marcas de industria e comercio}

Art. 353 - Violar direito decorrente de marca de industria ou de comércio:

I - reproduzindo, por qualquer meio, no todo ou em parte, sem licença do dono, marca de indústria ou de comércio devidamente registrada;

II - imitando marca, de modo que possa iludir o consumidor;

III - usando marca assim imitada;

IV - usando marea falsificada no todo ou em parte;

V - vendendo ou expondo á venda:

a) artigo ou produto de falsa procedencia;

b) artigo ou produto revestido de marea imitada ou falsificada no todo ou em parte;

c) artigo ou produto revestido de marca alheia, que não proceda do dono da marca.

Pena - detenção por 3 meses a 1 ano e multa de 1 a 15:000\$000.

$\S 10^{\circ}$ - Para que se dê a imitação, ou usurpação, não é preciso que seja completa a semelhança entre as duas marcas, bastando a possibilidade de erro ou confusão, que se verifica sempre que as diferenças entre elas não sejam reconheciveis sem conírontação ou exame atento. 
$\S 2 .^{\circ}$ - Sómente se procederá, nos crimes definidos neste dispositivo, mediante queixa.

Pro. Omisso.

Cons. 353: identico na substancia, salvo quanto á pena. (multa de $500 \$$ a $5: 000 \$ 000)$.

Art. 354 - Punir-se-á, mediante queixa, com multa de 500\$ a 5:000\$000 aquele que:

I - usar, sem autorização de quem de direito, armas, brazão ou distintivo público ou oficial, nacional ou estrangeiro, ou marca de industria ou de comércio, quer o reproduza, quer o imite de maneira que não seja reconhecivel sem exame atento ou confrontação;

III - usar marca ofensiva ao decôro público;

IV - usar marca, em que figure falsa indicação da localidade ou estabelecimento da procedencia do produto ou artigo, embora a indicação se junte a nome suposto ou alheio;

$\mathrm{V}$ - vender ou expuser á venda produto ou artigo, onde se encontre marca de indústria ou de comercio que contravenha no disposto nos ns. I, III e IV.

$\S$ unico - Punir-se-á, mediante queixa, com detenção por 3 meses a 1 ano e multa de 1 a 10:000\$000 aquele que usar marca de industria ou de comercio em que se encontre ofensa pessoal, ou vender ou expuser á venda artigo ou produto revestido de marca de tal natureza.

Pr. Omisso.

Cons. 354: conforme, salvo quanto ás penas são de multa de 200 a 2:000\$000, e prisão por 2 a 6 meses e multa de $100 \$$ a $500 \$ 000$.

Art. 355 - Respondem solidariamente pelos crimes definidos nos dois artigos precedentes:

I - o dono da oficina, em que se imitar ou falsificar a marca; II quem a vender ou tiver sob sua guarda; 
III - o morador ou ocupante do predio onde estiver depositado o produto ou artigo, quando não possa provar quem seja o dono deste;

IV - quem comprar o produto ou artigo a pessoa desconhecida ou não justificar a procedencia dele.

$\S$ unico - Dobrar-se-ão as penas na reincidencia de qualquer dos referidos crimes, se não tiverem decorrido dez anos sobre a condenação anterior.

Pro. Omisso.

Cons. 355: conforme, na substancia.

\section{TITULO XII}

\section{Dos crimes contra o patrimonio}

\section{Capitulo I}

\section{Do furto}

Art. 356 - Subtrair, para si ou para outrem, cousa movel alheia.

Penas - reclusão por 1 a 3 anos e multa de 500\$000 a $5: 000 \$ 000$.

$\S 10^{\circ}$ - A pena será de reclusão por 2 a 5 anos e multa de $1: 000 \$ 000$ a $10: 000 \$ 000$ se o agente cometer o crime :

I - com o concurso de duas ou mais pessôas;

II - por ocasião de incendio, inundação ou outra calamidade pública ;

III - munido de arma, narcótico ou instrumento proprio para roubar, dos quaes, todavia, se não utilize;

IV - mascarado ou com outro disfarce.

$\S 2 .^{\circ}-$ Em se tratando de criminoso primario e não ocorrendo qualquer das circunstancias indicadas no $\S 1 .^{\circ}$, poderá o juiz diminuir a pena, ou substituir a reclusão pela detenção, ou impôr 
sómente a multa de $100 \$ 000$ a $2: 000 \$ 000$, se o agente cometer 0 crime :

I - com o único objetivo de usar momentaneamente da cousa, restituindo-a, no mesmo estado, voluntária e imediatamente depois de usá-la;

II - com referencia a cousa de valôr diminuto, para prover a grave e urgente necessidade física.

$\S 3 .^{\circ}$ - Equipara-se á cousa movel, para os efeitos penaes, a energia elétrica ou de outra natureza, que tenha valôr econômico.

Pr. 186: Aquele que, para si ou para outrem, tirar cousa alheia movel contra a vontade de seu dono, será punido com prisão até 3 anos. Quando se tratar de criminoso primario e o caso carecer de gravidạde, poderá o juiz aplicar a pena abaixo do mínimo genérico, ou substitui-la pela medida de segurança que as circunstancias indicarem. A prisão será por 2 a 6 anos, quando o inculpado: 1) tiver agido como filiado a quadrilha ou bando; 2) se revelar especialmente perigoso, pelo modo por que tenha cometido ou tentado cometer o crime. $\$ 10^{\circ}-$ Considera-se cous amovel, para os efeitos penaes, não só a energia elétrica, como qualquer outra que tenha valôr econômico. $\S 20^{\circ}$ - Cometerá furto o que se apropriar do animal alheio de que se tenha tornado detentor, ou que ferrar ou contraferrar animal alheio com outra marca, que não a do proprio dono, salvo se o tiver feito a seu mando, ou de seu preposto. $\S 3 .^{\circ}$ - Quando o objéto do furto forem cousas de pequeno valôr destinadas á administração, não se procederá de oficio, e, tal seja a situação do inculpado, poderá o juiz se abster de qualquer pena, ou substitui-la pela medida de segurança que as circunstancias indicarem. $\S 40^{\circ}-$ Não será punivel por furto aquele que, sem a deteriorar ou desvalorizar, restituir ao dono a cousa movel que sómente lhe tenha tirado para uso momentaneo.

Cons. 330 - Subtrair, para si ou para ôtrem, cousa alheia movel, contra a vontade de seu dono: $\S 10^{\circ}-$ Se o objéto furtado fôr de valôr inferior a $50 \$-1$ a 3 meses e multa de 5 a $20 \%$. $\$ 2 .{ }^{\circ}-$ Se de valôr inferior a $100 \$-2$ a 4 meses e a mesma multa. $\S 3 .^{\circ}-$ Se de valôr inferior a $200 \$-3$ a 6 meses e a mesma multa. $\S 4 .^{\circ}-$ Se de valôr egual ou excedente a $200 \$-6$ meses a 3 anos e a mesma multa. $\S 5 .^{\circ}$ - O furto de gado vacum, cavalar e muar será punido com a penalidade do $\S$ anterior, sendo a multa em relação ao valôr do objéto (!) furtado. 331: E' crime de furto... $4 .^{\circ}$ apropriar-se, em proveito próprio ou alheio, de animaes de qualquer especie pertencentes a outrem. $\S 10^{\circ}$ Se os animaes forem tirados de pastos de fazendas de creação ou 
de lavoura - a mesma multa, acrescida com a 6.a parte a pena corporal. § 2. ${ }^{\circ}$ Nas penas do § precedente incorrerá aquele que subtraír produtos de estabelecimento de lavoura, qualquer que seja a sua denominação (!) e gênero de cultura; de estabelecimento de salga ou preparo de carnes, peixes, banhas e couros, não estando esses produtos rcolhidos em depositos, armazens ou celeiros fechados.

Art. 357 - Subtrair o condómino, co-herdeiro ou sócio, para si ou para outrem, cousa movel comum, a quem a detiver.

Pena - detenção por 6 meses a 2 anos, ou multa de 1 a $10: 000 \$ 000$.

$\S 1 .^{\circ}$ - Não será punivel a subtração de cousa comum fungivel, se o valôr desta não exceder a quota a que tiver direito o agente.

$\S 2 .^{\circ}$ - Sómente se procederá mediante representação.

Pr. 188 - Mediante representação será punido com detenção até 6 meses ou com multa aquele que.. 3) tirar a cousa comum do poder de quem legitimamente a detiver.

Cons. 334 - $O$ crime de furto se cometerá, ainda que a cousa pertença a herança ou comunhão em estado de indivisão.

Art. 358 - Subtrair, para si ou para outrem, processo, folha ou peça de autos ou livros judiciaes, ou qualquer documento suscetivel de produzir efeito jurídico.

Pena - reclusão por 1 a 3 anos e multa de 500\$000 a $5: 000 \$ 000$.

Pr. Omisso.

Cons. 333 - Subtrair processo, folhas, peças de autos ou livros judiciaes, titulos, documentos, testamentos e, em geral qualquer instrumento suscetível de efeitos juridicos -6 meses a 3 anos e multa de 200\$. a $600 \$$. § un. Se o furto fôr de objétos ou papeis depositados em arquívos púbicos ou estabelecimentos incumbidos pela lei de os guardar ou conservar - a do art. precedente com o aumento da $6 .{ }^{\mathrm{a}}$ parte.

\section{Capitulo IL}

\section{Do roubo}

Art. 359 - Subtrair, para si ou para ôutrem, cousa movel (art. $356 \S 3 .^{\circ}$ ), total parcialmente alheia, fazendo violencia á pessôa ou á cousa. 
Pena - 2 a 8 anos de reclusão.

$\S 1 .^{\circ}-$ Constituem violencia :

I - as vias de fato, a ameaça e outros meios que enfraqueçam ou anulem a resistencia individual;

II - o fato do agente fingir-se autoridade ou funcionario público ou autorizado a tomar a propriedade alheia;

III - a entrada ou saída da casa por outra via que não a destinada ao ingresso no edificio ou suas dependencias; ou mediante arrombamento ou emprego de chave falsa, ou de verdadeira, obtida fortuita ou subrepticiamente; ou com a conivencia de empregado ou morador da casa;

IV - o emprego de força, ou de chave, ou de outro aparelho ou instrumento, para vencer obstáculo á subtração da cousa.

$\S 20^{\circ}$ - Não importa á qualificação do crime, que a violencia seja anterior, concomitante ou posterior á subtração, uma vez que tenha concorrido para facilitá-la, ou para assegurar ao agente a detenção da cousa, ou para garantir a impunidade própria ou alheia.

$\S 3 .^{\circ}$ - A pena será de reclusão por 3 a 10 anos:

I - quando ocorrer qualquer das circunstancias indicadas no art. I, II e VI;

II - quando o agente usar de arma, como meio de intimidação, ou de narcótico ou substancia de efeitos análogos, para enfraquecer ou anular a resistencia de alguem.

$\S 40^{\circ}$ - A pena do crime consumado ou tentado será:

I — de reclusão por 5 a 15 anos, se da violencia resultar lesão grave ou gravissima;

II - de reclusão por 15 a 30 anos, se da violencia resultar a morte.

Pr. 190 - Aquele que para cometer furto, ou surpreendido em flagrante de furto, usar de violencia contra alguma pessôa, ameaçá-la com perigo iminente para a vida ou a integridade corpórea, sua ou de outrem; ou previamente a reduzir á incapacidade de resistir, será punido com prisão por 2 a 6 anos. 0 mínimo de prisão será de 3 anos, quando o criminoso tiver agido como filiado a quadrilha ou bando. Esta alinea é aplicavel áquele que tendo cometido ou tentado cometer furto, se encontrar nas condições previstas nos n. ${ }^{\circ}$ s 3 e 4 do $\S$ un. do art. 165. 
Cons. 356 - Subtrair, para si ou para outrem, cousa alheia movel, fazendo violencia á pessôa ou empregando força contra a cousa -2 a 5 anos. 357: Julgar-se-á feita violencia á pessôa todas as vezes que, por meio de lesões corporaes, ameaças ou outro qualquer modo, se reduzir alguem a não poder defender os bens proprios ou alheios sob sua guarda. E' considerada violencia contra a pessôa a entrada á noite na casa por meio de escalada, gazuas, chaves falsas ou verdadeiras, fortuita ou subrepticiamento obtidas pelo criminoso, ou com auxilio de algum doméstico, que tenha sido subornado, ou fingindo-se o delinquente autoridade pública ou autorizado a tomar a propriedade alheia. 358: Julgar-se-á violencia feita ás cousas a destruição e rompimento dos obstáculos á perpetuação do crime. Constituem violencia contra as cousas os arromba. mentos internos e externos, a perfuração de paredes, a introdução dentro de casa por conduto subterraneo, por cima dos telhados ou por qualquer caminho que não seja destinado a servir de entrada ao edificio ou a qualquer de suas dependencias. 359: Se, para realizar o roubo, ou no momento de ser perpetrado, se cometer morte -12 a 30 anos. $\S 10^{\circ} \mathrm{Se}$ cometer-se alguma lesão corporal das especificadas no art. $304-4$ a 12 anos. 360: - A tentativa de roubo, quando se tiver realizado a violencia, ainda que não se opere a tirada da cousa lheia, será punida com as penas do crime, se dela resultar a morte a alguem, ou á pessôa ofendida alguma lesão corporal das especificadas no art. 304.

\section{Capitulo III}

\section{Da extorsão}

Art. 360 - Obter de alguem, mediante ameaça ou violencia, vantagem ilícita, em benefício próprio ou alheio.

Pena - reclusão por 2 a 8 anos e multa de $2: 000 \$ 000$ a $10: 000 \$ 000$.

$\S$ unico - Aumentar-se-á a pena :

I - se a ameaça consistir na promessa de revelação ou divulgação de fato, verdadeiro ou falso, que venha a prejudicar direta ou indiretamente o ofendido;

II - se a ameaça ou a violencia forem praticadas por pessoa armada, mascarada ou disfarçada, ou por mais de uma pessôa;

III - se o agente usar de narcótico ou substancia de efeitos análogos para enfraquecer ou anular a resistencia da vítima. 
Pr. 196 - Será punido com prisão até 5 anos e com multa aquele que: 1) para obter de alguma pessôa, para si ou para ôtrem, indevida vantagem economica, usar de violencia, ou ameaça com iminente perigo para a vida, ou a integridade corporea, sua ou de terceiro, ou previamente a reduzir á impossibilidade de resistir; $2 .^{\circ}$ ) para compelir alguma pessôa a comprar-lhe o silencio, a ameaçar com a revelação de fatos reservados de sua vida profissional ou doméstica, os quaes, uma vez divulgadas acarretariam a essa pessôa ou a alguem de sua familia sério incômodo moral, ou prejuizo moral ou económico. 0 mínimo da prisão será de 2 anos, quando o inculpado habitualmente se der á pratica da extorsão, ou quando reiteradas vezes tiver procurado extorquir dinheiro á vítima.

Cons. $362 \S 10^{\circ}$ - Extorquir de alguem vantagem ilícita pelo temor de grave dano á sua pessôa ou bens; constranger alguem, quer por ameaças de publicação infamante e falsas denuncias, quer simulando ordem de autoridade, ou fingindo-se tal, a mandar depositar ou pôr á disposição dinheiro, cousa ou ato que importe efeito juridico. $\S 2 .^{\circ}$ Obrigar alguem, com violencia ou ameaça de grave dano á sua pessôa ou bens, a assinar, escrever ou aniquilar, em prejuizo seu ou de outrem, um ato que importe efeito jurídico - 2 a 8 anos e multa de 5 a $20 \%$.

Art. 361 - Sequestrar alguem, para obter, em benefício próprio ou alheio, vantagem ou proveito, a título de resgate.

Pena - reclusão por 6 a 12 anos e multa de 5 a 10:000\$000.

$\S 1 .^{\circ}$ - A pena será de reclusão por 12 a 18 anos e multa de 10 a $20: 000 \$ 000$ :

I - se o sequestro perdurar por mais de 24 horas;

II - se o sequestrado fôr menor de 18 anos;

III - se o crime fôr cometido por bando ou quadrilha.

$\S 2 .^{\circ}$ - A pena será de reclusão por 18 a 30 anos e multa de 15 a $30: 000 \$ 000$, se o sequestrado sofrer lesão grave ou gravissima.

$\S 3 .^{\circ}$ - A pena será de morte, se morrer o sequestrado.

Pr. 230 - Aquele que raptar menores para lucrativamente explorá-los ou submete-los a resgate, será punido com prisão até 5 anos e com multa.

Cons. 362 - Sequestrar uma pessôa, para obter dela ou de outrem, como preço de sua libertação, dinheiro, cousa ou ato que importe qualquer efeito jurídico -2 a 8 anos e multa de 5 a $20 \%$ 
Art. 362 - Abusar da situação do devedor, exigindo ou aceitando cheque ou documento post-datado, como titulo ou garantia de obrigação não vencida.

Pena - multa de 100\$000 a 2:000\$000.

Pr. 197 - Aquele que sabendo, podendo ou devendo facilmente saber: 1) não dispôr o devedor de fundos no estabelecimento contra o qual pretendeu sacar; 2) não ser verdadeira a assinatura ou firma de terceiro, com que se proponha o devedor a garantir-lhe a divida; exigir ou aceitar cheque ou qualquer outro documento em taes condições, será punido com as penas do artigo precedente, cuja alinea é aplicavel (até 5 anos e multa, ou mínimo de 2 anos).

Cons. Omissa.

\section{Capitulo IV}

\section{Da usurpação}

Art. 363 - Punir-se-á, mediante representação, com detenção por 3 meses a 3 anos e multa de $200 \$ 000$ a 5:000\$000 aquele que :

I - para se apropriar, no todo ou em parte, de predio alheio, suprimir ou deslocar tapume, marco ou outro sinal indicativo de linha divisoria;

II - para haver, em beneficio próprio ou alheio, vantagem ilícita, represar, desviar ou represar aguals alheias, públicas ou particulares ;

III - com violencia á pessoa ou ameaça, esbulhar ou turbar a posse pacífica de imovel, ou de enfiteuse, servidão, habitação ou anticrese, ou de uso ou usofruto de bens imobiliarios.

$\S 10^{\circ}$ - Considerar-se-á cometido com violencia á pessôa ou ameaça o crime quando praticado com o concurso de cinco ou mais pessôas.

§ 2. - Agravar-se-á a pena, se o crime fôr cometido em prejuizo de entidade de direito público.

$\S 3 .^{\circ}$ - Nos casos do $\S \S 10^{\circ}$ e $2 .^{\circ}$ proceder-se-á de oficio.

Pr. 318 (falsidade em documentos publicos ou particulares!) Aquele que, para alterar a situação jurídica ou propriedade imobiliaria, 
suprimir, remover ou substituir os marcos, testemunhas e sinaes quer oficiaes ou judicialmente, lhe fixarem os limites, será punido com detenção por 2 meses no mínimo e com multa.

Cons. 329: (dano): $\S 10^{\circ}$ - Se a destruição ou danificação fôr de cousas que sirvam para distinguir ou separar os limites da propriedade imovel, urbana ou rural; $\S 20^{\circ}$ Se para desviar de um curso agua de uso público ou particular - 1 a 6 meses e 5 a $20 \%$ do dano causado. $\S 3 .^{\circ}$ - Se o fato fôr praticado com violencia ou ameaça contra a pessôa, ou por mais de 2 pessôas, com armas ou sem elas - as do art. 356 (roubo -2 a 8 anos).

\section{Capitulo V}

\section{Do dano}

Art. 364 - Destruir, inutilizar ou deteriorar cousa alheia.

Pena - detenção por 15 dias a 6 meses ou multa de $100 \$$ a $2: 000 \$ 000$.

$\S 10^{\circ}-$ Se o crime fôr cometido:

I - com violencia á pessôa ou ameaça;

II - mediante o emprego de substancia inflamavel, tóxica ou explosiva ;

III - em bens do dominio da União, de Estado ou de Municipio, ou edificio público, ou destinado ao exercicio de culto, ou cousa existente em edificio dessa natureza, ou colocada ou exposta em logar público.

Pena - detenção por 3 meses a 2 anos e multa de $500 \$ 000$ a $5: 000 \$ 000$.

$\S 2 .^{\circ}$ - Se o crime consistir em destruir, subtrair, ocultar ou inutilizar total ou parcialmente livro de notas ou de outra natureza empregado em serviço público; ou processo judicial ou administrativo; ou ato original de autoridade pública; ou livro de escrituração mercantil; ou testamento ou codicilo, letra de cambio ou outro título ou documento particular, cuja destruição, ocultação ou inutilização cause prejuizo ao patrimonio alheio.

Peúa - reclusão por 1 a 4 anos e multa de 500\$ a 5:000\$000; diminuindo-se porém, as penas, convertendo-se em detenção a re- 
clusão, se o documento subtraido ou ocultado fôr restituido antes do julgamento.

$\S 3 .^{\circ}$ - Se o crime definido no $\S 20^{\circ}$ fôr cometido com o intuito de haver o agente, para si ou para outrem, vantagem ilícita, ou, com abuso da função, por funcionario publico, ou por advogado, perits, intérprete ou outro auxiliar da justiça.

Penas - as mesmas do $\S 2 .^{\circ}$, elevadas ao dobro, observando tambem o que aí se dispõe para o caso de restituição, antes do julgamento, do documento ocultado ou subtraido.

$\S 4 .^{\circ}$ Se o crime consistir em matar, inutilizar ou danificar, sem necessidade, animal pertencente a outrem.

Pena - detenção por 15 dias a 6 meses ou multa de $100 \$$ a 2:000\$000.

§ $50^{\circ}$ - Só mediante queixa se procederá no caso da cabeça do artigo e no do $\S 4 .^{\circ}$.

Pr. Omisso.

Cons. Omissa.

Pr. 192 - Aquele que destruir, danificar ou privar de uso a cousa alheia será punido com detenção até 1 ano ou com prisão até 2 anos. A pena será de prisão por 2 a 5 anos, quando egoisticos os moveis do crime e consideravel o prejuizo. Em qualqueh hipótese a multa é cumulavel.

Cons. 326 - Destruir ou inutilizar livros de notas, registos, assentamentos, atas e termos; autos e atos assinados de autoridade pública; livros comerciaes e em geral todo e qualquer papel, titulo ou documentos que sirva para fundamentar ou provar direitos, sem haver lucro ou vantagens para si ou para outrem - 2 a um ano e multa de 5 a $20 \%$ do dano causado. $\S 1-$ Se o crime fôr cometido auferindo o delinquente proveito para si ou para outrem -1 , 4 anos e multa de 5 a $20 \%$ do valôr do dano causado ou que poderia causar. 327: Demolir ou destruir de qualquer modo, no todo ou em parte, edificio concluido ou somente começado, pertencente á Nação, Estado, Municipio ou a particular 1 a 4 anos e multa de 10 a $20 \%$ do dano causado. 328: Destruir, abater, mutilar ou danificar monumentos, estatuas, ornamentos ou quaesquer objetos destinados á decoração, utilidade ou recreio público - 6 meses a 2 anos e multa de 5 a $20 \%$ do dano causado. 329: Destruir ou danificar cousa alheia de qualquer valôr, movel, imovel ou semovente 1 a 3 meses e multa de 5 a $20 \%$ do dano causado. $\$ 10^{\circ}$ - Se a destruição ou danificação fôr de cousa, que sirvam para distinguir ou separa: 
os limites da propriedade imovel, urbana ou rural. § $20^{\circ}-$ Se para desviar de seu curso agua de uso público ou particular -1 a 6 meses e multa de 5 a $20 \%$ do dano causado. $\S 3 .^{\circ}$ - Se o fato fôr praticado com violencia ou ameaças contra a pessôa ou por mais de duas pessôas com armas ou sem elas - a do art. 356 (roubo). $\$ 4 .^{\circ}$ - Se os crimes... forem praticados por meio de bombas de dinamite ou de outros explosivos eguaes ou semelhantes em seus efeitos aos da dinamite -2 a 8 anos.

Art. 365 - Entrar em propriedade alheia, sem permissão do proprietario, para caçar ou pescar.

Pena - multa de 100\$ a $2: 000 \$ 000$.

$\S 1 .^{\circ}$ - Aumentar-se-á a pena :

I - se o crime fôr cometido em logar ou período interditos á caça ou pesca;

II - se 0 agente não tiver licença da autoridade, quando necessaria.

$\S 20^{\circ}-$ Não se procederá senão mediante queixa.

Pr. Omisso.

Cons. Omissa.

Art. 366 - Introduzir ou abandonar rebanho ou manada de animais em propriedade alheia, sem permissão do proprietario desta.

Pena - multa de 100\$ a 1:000\$.

$\S 1 .^{\circ}$ - Se os animais, embora não estes reunidos em manada ou rebanho, forem introdusidos ou abandonados na propriedade alheia, para o efeito de pastagem.

Pena - detenção por 3 meses a 1 ano, ou multa de 500\$ a $3: 000 \$$.

$\S 20^{\circ}$ - Se do fato resultar dano para a propriedade.

Pena - as do $\S 1 .^{\circ}$, aumentadas e aplicadas cumulativamente.

§ $3^{\circ}$ - Não se procederá senão mediante queixa.

Art. 367 - Destruir inutilizar ou deteriorar cousa propria, tombada pela autoridade competente, como parte do patrimonio arqueológico, histórico ou artistico nacional.

Pena - detenção por 1 mês a 1 ano, ou multa de 1 a 20 contos, podendo o juiz determinar a confiscação da cousa inutilizada ou deteriorada. 
Pr. Omisso.

Cons. Omissa.

Art. 368 - Destruir ou alterar, mediante construção, demoliȩão ou de outra maneira, a beleza natural de logar submetido á proteção especial da autoridade.

Pena - multa de 500\$ a 20:000\$000.

Pr. Omisso.

Cons. Omissa.

\section{Capitulo VI}

\section{Da apropriação indebita}

Art. 369 - Apropriar-se, para si ou para outrem, de cousa movel alheia, em poder do agente, por titulo que obrigue a restitui-la ou a fazer dela uso determinado.

Pena - reclusão por 1 a 3 anos e multa de 200\$ a 10:000\$000.

$\S 10^{\circ}$ - Aumentar-se-á a pena, se o agente houver recebido a cousa :

I - em deposito necessario (Cod. Civ. art. 1.282);

II - na qualidade de tutor, eurador, síndico, liquidatario, inventariante, testamenteiro ou depositario judicial;

III - em razão do oficio, emprego ou profissão.

$\S 2 .^{\circ}$ - Responde por apropriação indébita quem ferrar ou contra-ferrar animal alheio com outra marca, que não a do dono, sem autorização deste.

Pr. 187 - Mediante representação, será punido com detenção $€$ multa aquele que: 1) se apropriar da cousa alheia movel que lhe tenha sido confiada; 2) sem direito se utilisar, em proveito próprio ou de outrem, de titulo, valôx ou dinheiro que lhe tenham sido confiados. A pena privativa da liberdade será a de prisão até 5 anos, quando: 1) se tratar de depósitos necessarios; 2) tiver agido o inculpado na qualidade de tutor, curador, sindico, liquidatario ou no exercicio acidental de funções que lhe tenha cometido alguma autoridade pública.

Cons. 331 - E' crime de furto, sujeito ás mesmas penas e guardadas as restrições do art. precedente... apropriar-se de cousa alheia que lhe houver sido confiada ou consignada por qualquer titulo, com 
obrigação de a restituir ou fazer dela uso determinado... apropriar-se, em proveito próprio ou alheio, de animaes de qualquer especie pertencentes a outrem.

Art. 370 - Punir-se-á, mediante queixa, com detenção por 1 mês a 1 ano, ou multa de 200\$000 a 3:000\$000, aquele que:

I - achar tesouro em predio alheio, e apropriar-se, no todo ou em parte, da quota correspondente ao proprietario do imovel (Cod. Civ. art. 607);

II - achar cousa perdida, que não lhe pertença, e dela apropriar-se, total ou parcialmente, deixando de restitui-la ao dono ou legitimo possuidor, quando o conheça, ou de entregá-la, no caso contrario, á autoridade competente (cod. civ. art. 603);

III - apropriar-se de cousa alheia, que tenha vindo ao seu poder, em consequencia de erro, caso fortuito ou força maior.

Pr. 188 - Mediante representação, será punido com detenção até 6 meses ou com multa aquele que: 1) não proceder, a respeito da cousa achada, ou do tesouro, na conformidade da lei civil (Cod. Civ. arts. 603 e 607 a 610); 2) se apropriar de cousa alheia movel, que lhe tenha vindo ás mãos por efeito de força natural, por erro, engano ou caso fortuito...

Cons. 331 - E' crime de furto... 1) apropriar-se alguem de cousa alheia que venha ao seu poder por exro, engano ou caso fortuito... 2) apropriar-se de cousa alheia achada, deixando de a restituir ao dono, se a reclamar ou se manifestaá-la, dentro de 15 dias, á autoridade competente...

\section{Capitulo VII}

\section{Do estelionato, do abuso de confiança e outras fraudes}

Art. 371 - Haver, para si ou para outrem, vantagem ilícita, em prejuizo alheio, induzindo ou mantendo alguem em erro, mediante artificio, ardil ou qualquer outro meio fraudulento.

Pena - reclusão por 1 a 5 anos e multa de 500\$ a 10:000\$000.

$\S 1 .^{\circ}$ - Incorrerá neste dispositivo quem:

I - vender, permutar ou dér em locação ou garantia cousa alheia como própria; 
II - vender, permutar ou dér em garantia cousa própria, mas inalienavel, ou gravada de onus, ou litigiosa, ou imovel que esteja comprometido a vender em prestações a terceiro (decreto-lei n. 58, de 1937), calando a existencia da inalienabilidade, ou do onus, ou do litígio ou do compromisso em vigor;

III - defraudar, mediante alienação não consentida pelo credor ou de outra maneira, a garantia pignoraticia, quando tenha a posse do objéto empenhado por efeito da clausula constituti (Cod. Civ. art. 769).

IV - defraudar alguem na substancia, qualidade ou quantidade da cousa, que, por qualquer título, deva entregar-lhe;

$\nabla$ - prestar contas fraudulentas de comissão, mandato on administração de negocio alheio;

VI - destrụir, danificar ou ocultar cousa segurada, ou lesar o proprio corpo ou saude ou agravar as consequencias da propria lesão ou doença, com o intuito de haver indenização para si ou para outrem.

VII - emitir fraudulentamente, cheque, sem ter suficiente provisão de fundos em poder do sacado.

§ 2. - Aumentar-se-á pena, quando o crime fôr cometido:

I - em detrimento de entidade de direito público ou de economia popular, ou de instituto de assistencia social ou beneficiencia;

II - nos casos da cabeça do artigo, com apelo ao público para concorrer com dinheiro ou bens;

III - nos casos dos ns. I e II do $\S 1^{\circ}$, com oferta ao público para a venda em prestações.

Pr. 193 - Aquele que, visando a lucro ilegítimo, seu ou de outrem, astuciosamente induzir alguma pessôa em erro, ou neste mantiver, dissimulando ou alterando fatos verdadeiros, ou como taes fazendo acreditar os falsos, e por esta maneira a determinar á prática de atos que, a ela propria ou a terceiro patrimonialmente prejudiquem, será punido com prisão até 5 anos. A prisão será por 3 a 9 anos, quando resultar do estelionato prejuizo consideravel, ou prejudicadas forem varias pessôas

Cons. 338 - Julgar-se-á crime de estelionato: 1) alheiar a cousa alheia como própria, ou trocar por outras as cousas que se deverem entregar; 2) alheiar, locar ou aforar a cousa própria já alheiada, locada ou aforada; 3) dar em caução, penhora ou hipoteca bens que não puderem 
ser alheiados, ou estiverem gravados de onus reaes e encargos legaes e judiciaes, afirmando a isenção deles; 4) alheiar ou desviar os objétos dados em penhor agricola, sem consentimento do credor, ou por qualquer modo defraudar a garantia pignoraticia; 5) usar de artificio para surprender a bôa fé de outrem, iludir a sua vigilancia ou ganhar-lhe a confiança; e, induzindo-o a erro ou engano por esses ou outros meios astuciosos, procurar para si lucro ou proveito.. 11) - alterar a qualidade e o peso dos metaes nas obras que lhe forem recomendadas; substituir pedras verdadeiras por falsas ou por outras de valor inferior; vender pedras falsas por finas ou vender como ouro, prata ou qualquer metal fino objétos de diversa qualidade -1 a 4 anos e multa de $5 \%$ do valôr do objéto sobre que recair o crime. 339: Quando o valór do objéto sobre que recair o estelionato não exceder a $100 \$$, a pena será de... 2 meses a 1 ano, além da multa. 140: Incendiar o próprio dono qualquer das cousas precedentemente especificadas, com o propósito de crear um caso de responsabilidade contra terceiro ou defraudar os direitos de alguem - 1 a 6 anos e multa de 5 a $20 \%$ do valôr do dano causado ou que poderia causar.

Art. 372 - Abusar em proveito proprio ou alheio, das necessidades, paixões ou inexperiencia de menor não emancipado, ou do estado de enfermidade ou debilidade mental de alguem, embora não interdicto, induzindo-o a praticar um ato destinado a produzir efeito jurídico, danoso para si mesmo ou para outrem.

Pena - reclusão por 2 a 6 anos e multa de 1 a $5: 000 \$$.

Pr. 198 - Aquele que, abusando, em proveito próprio ou alheio, da inferioridade psiquica, debilidade mental, rusticidade ou simples a de alguma pessôa, a induzir a comprometer-se em atos lesivos ao patrimonio próprio ou de outrem, a especular na Bolsa ou a se arriscar a jogos de azar ou de corridas, será punido, quando em pena mais grave não incorrer, com prisão até 3 anos e com multa.

Cons. 338 - Abusar, em próprio ou alheio proveito, das paixões ou inexperiencia de menor, interdicto ou incapaz, e faze-lo subscrever ato que importe efeito jurídico em dano dele ou de outrem, não obstante a nulidade do ato emanado da incapacidade pessoal.

Art. 373 - Abusar, em proveito próprio ou alheio, da inexperiencia ou da simplicidade ou inferioridade mental de ôutrem, induzindo a vítima a especular no jogo, ou em títulos ou mercadorias, sabendo ou devendo saber tratar-se de operações ruinosas e desproporcionadas á fortuna da vítima. 
Pena - reclusão por 1 a 3 anos e multa de 500\$ a 3:000\$000.

Pr. 198 - ... a especular na Bolsa ou a se arriscar a jogos de azar ou de corridas...

Cons. Omissa.

Art. 374 - Punir-se-á com detenção por 6 meses a 2 anos ou multa por 1 a 10:000\$000 ou ambas cumulativamente, se o fato não constituir crime mais grave, aquele que, no exercicio de atividade comercial, enganar o adquirente ou consumidor:

I - usando de falsos pesos ou medidas;

II - vendendo, como verdadeira ou perfeita, mercadoria falsificada ou deteriorada;

III - entregando uma mercadoria por outra.

§ único - A pena será de reclusão por 1 a 4 anos e multa de 1 a 15:000\$000, quando o agente:

I - em obra que lhe fôr encomendada, alterar a qualidade ou o peso do metal, ou substituir pedra verdadeira por falsa ou outra menos valiosa;

II — vender pedra falsa por verdadeira;

III — vender como ouro, prata ou metal precioso cousa de outra qualidade.

Pr. 303: § um - Incorrerá nas mesmas penas (prisão até 3 anos e multa) aquele que cientemente usar dos objetos referidos neste artigo (pesos, balanças, etc.) e no caso de culpa incorrerá em multa.

Cons. 338: $\S 10^{\circ}$ - Alterar a qualidade e $\circ$ peso dos metaes nas obras que lhe forem encomendadas; substituir pedras verdadeiras por falsas, ou por outras de valôr inferior; vender pedras falsas por finas, ou vender como ouro, prata, ou qualquer metal fino objetos de diversa qualidade -1 a 4 anos e multa de 5 a $20 \%$ do valor do objeto.

Art. 375 - Fabricar, ou vender, ou expôr á venda, ou ter em deposito para consumo público, genero alimenticio que, embora não seja nocivo á saude;

I - tenha sido misturado ou acondicionado com substancia que lhe altere a qualidade ou reduza o valor nutritivo, uma vez que se não torne bem explicita a modificação que o torna de qualidade inferior; 
II - de que se haja retirado, no todo ou em parte. elemento de sua composição normal, ou substituido por outro de qualidade inferior, uma vez que tal depreciação não fique bem explícita;

III - a que se tenha adicionado substancia extranha, para ocultar deterioração ou fraude ou para lhe atribuir qualidade superior áquela que em verdade tiver;

IV - que tenha sido, no todo ou em parte substituido ao indicado no recipiente, ou que diversifique, na composição, peso ou medida, do enunciado na marca, rótulo, ou anuncio, ou declarado pelo vendedor ou fabricante.

Pena - reclusão por 1 a 4 anos e multa de 1 a $15: 000 \$ 00$.

Pr. 195 - Será punido com detenção até 6 meses ou multa aquele que, para enganar o adquirente ou consumidor; 1) contrafizer, falsificar ou alterar qualquer mercadoria; 2) puser em circulação ou expuser á venda mercadoria contrafeita, falsificada ou alterada. A multa será a unica pena aplicavel no caso do n. ${ }^{\circ}$, quando sómente responder por culpa. 424: Aquele que aceitar em depósito, ou para guardar, mercadorias contrafeitas ou deterioradas, sabendo que as mesmas podem servir para enganar terceiros em relações comerciaes, será punido com detenção até 1 mês ou com multa.

Cons. 163 - Conforme, na substancia.

Art. 376 - Abusar, em proveito próprio ou alheio, da situação de alguem, para que lhe dê ou prometa, em compensação de prestação de dinheiro ou outra cousa movel, comissão ou juros onzenarios.

Pena - detenção por 1 mês a 1 ano ou multa de $500 \$$ a $2: 000 \$ 000$.

$\S$ unico - Aumentar-se-á a pena, quando o agente:

I - praticar habitualmente a usura;

II - levar cientemente a vítima á ruina.

Pr. Omisso.

Cons.

Art. 377 - Punir-se-á com detenção por 15 a 90 dias ou multa de $200 \$ 000$ a 1:000\$000 aquele que, sabendo ser-lhe impossivel efetuar o pagamento:

I - alojar.se em hotel ou estabelecimento congênere; 

II - tomar refeição em casa de pasto ou estabelecimento análogo;
III - utilizar-se de meio oneroso de transporte;
IV - introduzir-se em local de diversões, em que se exija pagamento á entrada.

$\S$ unico - Efetuado o pagamento antes de transitar em julgado a sentença condenatoria, substituir-se-á a pena pela liberdade vigiada ou caução de bom comportamento, uma vez que não se trate de criminoso reincidente, habitual ou por índole.

Pr. 427 - Aquele que se tiver feito servir alimentos ou bebidas em restaurantes, confeitarias e estabelecimentos do mesmo genero, deliberado a não pagar a despesa ou sabendo não poder faze-lo, será punido com detenção até 6 dias.

Cons. Omissa.

Art. 378 - Incorrerão nas penas de reclusão por 1 a 4 anos e multa de 1 a 10:000\$000 os administradores de sociedades anônimas ou em comandita por ações :

I - que deixarem de publicar e arquivar no prazo legal resolução ou deliberação da sociedade, nos casos expressos em lei;

II - que derem indicações inexatas sobre a importancia do capital subscrito e efetivamente entrado para a sociedade;

III - que distribuirem dividendos manifestamente fictícios, desfalcando assim o capital;

IV - que comprarem ou venderem ações da sociedade, por conta desta, salvo o caso de aquisição para amortisá-las.

$\mathrm{V}$ - que, em garantia de crédito social, aceitarem peuhor de ações da própria sociedade;

VI - que artificiosamente promoverem falsa cotação das ações;

VII - que emitirem conhecimento de depósito e warrant em desacôrào com as disposições legaes.

VIII - que, no caso de falencia, subtrairem ou inutilizarem os livros da sociedade, ou lhes alterarem o conteúdo. ou diminuirem, desviarem ou ocultarem parte do ativo; ou, em balanço ou qualquer instrumento particular ou público, atribuirem divida irreal á sociedade. 
§ unico - Responderão pel crime, nos termos do art. $17 \mathrm{n} . \mathrm{V}$, os fiscaes que deixarem de denunciar em seus pareceres a distribuição indébita de dividendo ou qualquer fraude praticada durante o exercicio e constante dos livros e papeis que devam examinar.

Pr. 194 - Aquele que, fazendo parte da administração ou do conselho fiscal de sociedade cujos titulos sejam admissiveis na Bolsa, distribuir, ou concorrer para que se distribuam dividendos á custa do capital social, ou com sacrificio do patrimonio social, seá punido com detenção até 6 meses e com multa. A pena será de prisão até 5 anos, quando o fato concorrer para a falencia da sociedade, e com ela se causar prejuizo consideravel, seja pelo seu montante, seja pelo numero das pessôas atingidas. 428: (contravenção): Será punido com multa aquele que como fundador, administrador ou membro do conselho fiscal da sociedade, cujos titulos sejam susceptiveis de cotações na Bolsa: 1) não fizer arquivar, registrar ou publicar no devido prazo documentos e deliberações que por lei deverem ser arquivados, registrados ou publicados; 2) negociar com as ações da sociedade por conta da mesma, salvo a faculdade legal de amortizá-las.

Cons. 340 - Incorrerão nas penas de prisão celular por 1 a 4 anos e multa de $100 \$$ a $500 \$$ : 1) os administradores de sociedades ou companhias anônimas que por conta delas, comprarem e venderem ações da smesmas sociedades ou companhias, salvo a faculdade de as amortizar na forma permitida por lei; 2) os administradores ou gerentes que distribuirem dividendos não devidos; 3) os administradores que por qualquer artificio, promoverem falsas cotações das ações; 4) os administradores que em garantia de créditos sociaes, aceitarem em penhor ou ações da propria companhia. § un. Serão coñsiderados cumplices os fiscaes que deixarem de denunciar nos seus relatorios anuaes a distribuição de dividendos não devidos, e quaesquer fraudes praticadas no decurso do ano, e constante nos livros e papeis sujeito sa seu exame. 341: Não ficam prejudicadas pela disposição do art. precedente as penas pecuniarias cominadas nas leis que regulam o estabelecimento das sociedades ou companhias anônimas, aos respetivos administradores e gerentes, por outras faltas em que incorrerem previstas nas mesmas leis. $\S 10^{\circ}-$ No caso de falencia de sociedade anônima, serão punidos com as penas do art. 340 os administradores ou gerentes que subtrairem os livros da mesma sociedade, inutilizarem-nos ou lhes alheiarem o conteúdo ;os que diminuirem, desviarem ou ocultarem parte do ativo, ou os que, com instrumentos publicos, em escritos particulares ou em balanços, reconhecerem a sociedade devedora de somas que efetivamente não deva. $\$ 20^{\circ}-$ Incorrerão nas penas de prisão celular por 1 a 4 anos os que emitirem os titulos denominados de conhecimento de deposito e warrant em desacôrdo com as disposições da lei em vigor. 


\section{Capitulo VIII}

\section{Da falencia e da fraude á execução}

Art. 379 - Responder por falencia qualificada fraudulenta no juizo comercial.

Pena - reclusão por 2 a 6 anos.

$\S$ único - Se a falencia fôr qualificada culposa.

Pena - detenção por 6 meses a 3 anos.

Pr. 303 - Punir-se-á o comerciante falido com detenção por 6 meses a 2 anos, se, no juizo comercial, tiver sido a falencia qualificada culposa, e com prisão por 1 a 4 anos, quando fraudulenta, desde que no juizo criminal a culpa ou a fraude ficarem provadas.

Cons. 336 - Todo comerciante, matriculado ou não, que fôr declarado em estado d efalencia, fica sujeito á ação criminal, se aquela fôr qualificada fraudulenta, na conformidade da lei em vigor. $\S 10^{\circ} \mathrm{Se}$ a falencia fôr qualificada fraudulenta -2 a 6 anos. $\$ 2 .^{\circ}-$ Se culposa - 1 a 4 anos. \& $30^{\circ}$ - A falencia dos corretores e agentes de leilóes sempre presume-se fraudulenta e será punida com as respetivas penas.

Art. 380 - Fraudar execução devedor não comerciante, alienando, desviando, destruindo ou danificando os proprios bens, maliciosamente, ou simulando dividas.

Pena - detenção por 6 meses a 2 anos ou multa de $500 \$$ a $5: 000 \$ 000$.

§ unico - Só mediante queixa haverá logar a ação criminal.

Pr. 204 - Mediante queixa, punir-se-á com detenção até 6 meses ou com multa o devedor que, na iminencia da execução ou do vencimento de titulo executivo, para prejudicar o credor alienar, sonegar, deteriorar ou destruir bens. Com a reparação do prejuizo previne a ação e se extingue a condenação.

Cons. 337 - O devedor não comerciante, que se constituir em insolvencia, ocultando ou alheando maliciosamente seus bens ou simulando dividas em fraude de seus credores legitimos, será punido com a pena de prisão de 6 meses a 2 anos. 


\section{Capitulo iX}

\section{Da receptação e outros crimes afins com os patrimoniaes}

Art. 381 - Adquirir, receber, ocultar ou concorrer de qualquer modo para ser adquirida, recebida ou ocultada cousa que o agente saiba proveniente de crime alheio, uma vez que o faça em proveito próprio ou de outrem que não o agente do crime principal (art. 188).

Pena - reclusão por 1 a 5 anos e multa de 500\$ a $10: 000$.

$\S$ único - Aplicar-se-á este dispositivo, ainda que o agente do crime principal não seja conhecido ou passivel de pena.

Pr. 191 - Aquele que adquirir, receber como dadiva ou penhor, ocultar, negociar, ou concorrer para que se negocie alguma cousa que saiba ou deva presumir ter sido obtida por meios criminosos, será punido com prisão até 3 anos, ou com prisão por 3 a 9 anos, quando receptador profissional, e, em ambos os casos, com multa. Tratando-se de criminoso primario, e sendo o caso de gravidade minima, poderá o juiz, aplicando a multa, fixar a pena de prisão abaixo do mínimo genérico.

Cons. 21 - Serão cúmplices... $\S 30^{\circ}$ - os que receberem, ocultarem ou comprarem coisas obtidas por meios criminosos, sabendo que o foram, ou devendo sabe-lo, pela qualidade ou condição das pessôas, de quem as houverem.

Art. 382 - Adquirir ou receber a qualquer título, sem verificação prévia da legitimidade da procedencia, cousa que, pela qualidade, ou pela desproporção entre o valôr e o preço, ou pela condição de quem a negociar, deixe presumir que foi obtida por meios criminosos.

Pena - detenção por 15 dias a 6 meses ou multa de $100 \$$ a $1: 000 \$$.

§ único - Incorrerá na mesma pena aquele que não denunciar imediatamente á autoridade o fato de haver conhecido a proveniencia criminosa de uma cousa, depois de havê-la adquirido ou recebido, a qualquer titulo, de bôa fé.

Pr. 425 (contravenção) - Aquele que, tendo recebido dinheiro ou valores, adquirido ou obtido cousas provenientes de algum crime, sem 
Thes conhecer, nem dever presumir a procedencia ilícita, não comunicar - fato á autoridade, logo que a conheça, será punido com detenção até 2 meses ou multa.

Cons. Omissa.

Art. 383 - Fabricar, ceder ou vender gazua ou instrumento proprio para roubar.

Pena - detenção por 6 meses a 2 anos e multa de $200 \$ 000$ a $1: 000 \$ 000$.

§ unico - Punir-se-á com detenção por 15 dias a 6 meses aquele que, no exercicio da profissão de serralheiro ou oficio análogo, abrir objéto ou logar, ou fornecer chave destinada a tal abertura, sem previamente verificar a legitimidade da pessôa com quem estiver tratando.

Pr. 423 (contravenção) - Aquele que como serralheiro, com chave diversa, ou qualquer outro instrumento, ou por meio mecânico, abrir porta ou objéto ao mando de alguem, sem previamente, certificar-se estar tratando com pessốa legítima para requerer-lhe a intervenção, será punido com detenção até 15 dias, desde que assim tiver inconcientemente concorrido para a prática de um ato ilícito ou em prejuizo de alguem.

Cons. 361 - Fabricar gazuas, chaves ou instrumentos próprios para roubar.

Art. 384 - Ter alguem em seu poder, depois de condenado por crime de furto ou de roubo, ou enquanto sujeito á liberdade vigiada ou caução de bom comportamento, ou quándo conhecido como vadio ou mendigo, valores ou cousas em decacordo com a propria condição e de proveniencia não justificada, ou gazua, chave falsa ou alterada, ou instrumento proprio para roubar, cuja destinação atual não justifique.

Pena — detenção por 3 meses a um ano.

Pr. 421 (contravenção) - Aquele que em estado de vadiagem, vagabundagem ou mendicancia, ou mais de uma vez processado por furto, fôr encontrado na posse de objétos, valores e dinheiro, sem poder justificá-la será sujeito a uma medida detentiva de segurança. § un. Os objétos, valores e dinheiro serão confiscados e depositados, para se restituirem ao legitimo dono, por ordem do juiz ou ao próprio contraventor, 
desde que como tal se legitime. Neste caso será ele imediatamente posto em liberdade, dando-lhe baixa na culpa. 422: Aquele que fôr encontrado na posse de gazuas, chaves falsas ou limadas e de outros objétos de que habitualmente se utilizem os ladrôes, e lhes não justificar a destinação atual e legitima, será punido com detenção por 15 dias a 2 meses. Os objétos suspeitos serão confiscados.

Cons. 361 - . te-los ou traze-los consigo de dia ou de noite 6 meses a 3 anos.

\section{Capitulo $\mathbf{X}$}

\section{Da periclitação do patrimonio}

Art. 385 - Ter ou explorar casa de tavolagem.

Pena - detenção por 3 meses a 2 anos ou multa de 5 a 15:000\$000, compreendidos, no confisco, não só os aparelhos e utensilios de jogo, como tambem os moveis e a decoração do local.

$\S 10^{\circ}$ - Incorrerá na mesma pena aquele que:

I - cientemente alugar ou ceder local para que outrem tenha ou explore casa de tavolagem;

II - bancar o jogo;

III - atrair pessoas para o jogo, ou procurar mantê-lo ou animá-lo, jogando sem risco, de conluio com o banqueiro.

§2. - Aumentar-se-á a pena :

I - se do jogo participar ou entre os empregados figurar menor de 18 anos;

II - se houver emprego de meio fraudulento, para assegurar 0 ganho.

$\S 30^{\circ}$ - Punir-se-á com detenção por 15 dias a 3 meses ou multa de 200\$ a 1:000\$000 aquele que participar do jogo.

$\S 4 .^{\circ}$ - Por casa de tavolagem se entende todo o logar acessivel ao público, mediante o pagamento de entrada, ou sem ele, em que se pratique jogo de azar. Considera-se jogo de azar aquele em que o ganho e a perda dependem exclusivamente ou quasi exclusivamente da sorte.

§ 5. - Excluem-se da proíbição legal: 
I - as apostas sobre corridas a pé ou a cavalo, ou outras semelhantes;

II - os estabelecimentos situados em estações balnearias, que sejam objeto de concessão e regulamentação pelo poder público.

Pr. 442 - Será punido com detenção até 2 meses ou com muita aquele que: 1) montar, mantiver ou exploral casa de jogo ou fornecer local para que outrem o faça; 2) desempenhar em taes casas o papel de banqueiro de jogo ou para este concorrer como auxiliar indispensavel; 3) atrair pessôas para o jogo, ou procurar mantê-lo ou animá-lo, jogando sem risco, de conluio com o banqueiro; 4) tomar parte no jogo, que em taes casas se fizer. Na reincidencia a detenção será por 2 a 6 meses, cumular-se-á com a multa, e esta, dobrada na 1.a, será triplicada nas reincidencias posteriores. § un. Em qualquer hipótese aplicar-se-á acessoriamente o confisco, que compreenderá: 1) os aparelhos, instrumentos e utensilios de jogo; 2) os moveis e adornos da sala de jogo, salvo, tratando-se de residencia particular, se eles não destoarem pelo seu luxo e conforto de mobiliario a decoração do resto da casa. 443: Casa de jogo, para os efeitos penaes, é todo o logar acessivel ao público, pague-se ou não a entrada, em que se realizem jogos de azar, quando deles habitualmente participarem pessôas que não sejam da familia de quem a ocupa; 2) os hoteis e casas de habitação coletiva, a cujos hospedes e moradores se proporcionem jogos de azar; 3) qualquer estabelecimento aberto ao público, em que se disfarce, sob a aparencia de negocio lícito, a realização do jogo de azar. 444: Jogo de azar é aquele em que o ganho e perda dependem exclusivamente da sorte. Nesta categoria compreende-se a aposta, não, porém, as que forem feitas no mesmo logar e no mesmo dia, em que públicamente se realizem exercicios ou desportos, que concorram para a cultura fisica no homem ou para o apuramento da raça nos animaes. 445: Aquele que admtir menor em casa de jogo, o incitar a jogar, ou com ele se aparceirar para esse fim, será punido com detenção por 1 a 3 meses.

Cons. 369 - Ter casa de tavolagem, onde habitualmente se reunam pessôas, embora não paguem entrada, para jogar jogos de azar, ou estabelecê-los em logar frequentado pelo público: 1 a 3 meses, perda ... e multa de $200 \$$ a $500 \$ 000$. \& $10^{\circ}$ Incorrerão na ... multa de $50 \$$ a $100 \$ 000$ os individuos que forem achados jogando. $\S 2 .^{\circ}$ Todo o logar em que é permitido o acesso de qualquer pessôa, mediante pagamento de entrada ou sem ela, para o fim de jogo, é considerado logar frequentado pelo público, para o efeito da lei penal. 370: Consideram-se jogos de azar aqueles em que o ganho e a perda dependem exclusivamente da sorte. § um. Não se compreendem na proíbição dos jogos de azar as apostas de corridas a pé ou a cavalo ou outras semelhantes. 371: Jogar com menores de 21 anos ou excitá-los a jogar -1 a 3 meses e multa de 
$50 \$$ a $100 \$ 000$. 372. Usar de violencia para obrigar alguem a jogar ou manter jogo - 1 a 6 meses, multa de 100\$ a 200\$000. 373: Usar de meios fraudulentos para assegurar a sorte no jogo ou o ganho na aposta - 1 a 4 anos. 374: Será julgado e punido como vadio todo aquele que se sustentar do jogo ...

Art. 386 - Punir-se-á com detenção por 6 meses a 2 anos ou multa de $2: 000 \$$ a $, 15: 000 \$ 000$, penas que serão dobradas e cumuladas na reincidencia, aquele que:

I - promover, sem autorisação legal, loteria ou rifa, isto é, operação que faça depender de sorteio a aquisição de dinheiro ou utilidade ;

II - introduzir ou vender bilhete de loteria estrangeira, ou vender bilhete de loteria estadual, fóra do territorio em que tiver jurisdição o poder concedente.

$\S 10^{\circ}$ - Punir-se-á com multa de 200\$ a $1: 000 \$ 000$, dobradas na reincidencia, aquele que publicar anuncio ou fizer propaganda de loteria ou rifa compreendida nos no. I e II deste artigo.

$\S 2 .^{\circ}$ - Em se tratando do chamado "jogo do bicho", feito mediante a venda de cautela ou de qualquer outra maneira, punir-se-ão:

I - com detenção por 6 meses a 1 ano, ou multa de 10 a $50: 000 \$ 000$, dobradas e acumuladas na reincidencia, o empresario ou banqueiro do jogo;

II - com detenção por 10 a 30 dias, ou multa de 200\$ a 1:000\$000, dobradas e acumuladas na reincidencia, aquele que comprar ou vender os bilhetes, ou promover-lhes ou facilitar-lhes o curso.

Pr. 446 - Considera-se loteria ou rifa: 1) toda operação em que se faça depender da sorte a obtenção de premio em dinheiro ou em bens, sem atenção ao nome que áquela se dê, nem ao processo de sorteio, recorra-se embora a simbolos, figuras ou projeções visuaes; 2) a venda de bens, mercadorias e quaesquer outro sobjétos por meio da sorte, seja qual fôr o processo do sorteio, ainda que sucessivamente ás extrações, todos os jogadores possam, mediante pagamentos totaes ou parciaes, vir a receber algum premio. § un. Não se compreendem nas disposições deste artigo as operações para o resgate dos titulos de companhia, que legalmente funcione, ou para o cumprimento periódico de suas obrigações. 447: A loteria ou rifa não autorizada por lei, ou que, sem auto- 
rização, correr anexa a outra loteria ou rifa autorizada, compreende-se na definição de jogo de azar; e aquele que a empreender, organizar, ou promover, a fizer corer ou extrair, lhe distribuir ou vender os bilhetes, lhe servir de agente, ou, por qualquer outro modo, salvo o caso do n. 2 do art. anterior, nela tomar parte, será punido com as penas do art. 442. Os bilhetes, registros e aparelhos de sorteios, os bens moveis e valores, sobre que versar a loteria ou rifa, serão confiscados. § un. Serão punidos com multa: 1) os que intervierem em taes loterias ou rifas com o intuito de obter o premio prometido; 2) os gerentes e administradores de jornaes ou oficinas tipograficas, os impressores de listas avulsas e os que por qualquer outra fórma publicarem ou fizerem publicar programas e avisos de loterias ou rifas, não autorizadas, os resultados de sua extração ou neles indicarem os logares onde as respetivas operações se realizam. A multa, dobrada na reincidencia, será progressivamente aumentada nas subsequentes reiterações.

Cons. 367 - E' expressamente proíbida a introdução ou venda, no territorio nacional, de bilhetes de loterias ou rifas estrangeiras, assim como a venda de loteria dos Estados, fóra da jurisdição dos governos que as tiverem concedido - apreensão e inutilisação dos bilhetes, valores, material, e multa de 50\$ a 10:000\$000. $\S 10^{\circ}$ Constitue loteria proíbida toda operação que faça depender de sorteio a aquisição de qualquer ganho ou lucro pecuniario. $\S 20^{\circ}$ São nulas de pleno direito quaesquer obrigações resultantes de loterias não autorizadas. $\S 3 .^{\circ} \mathbf{E}^{\prime}$ proíbida a publicação de anuncios, avisos ou noticias de propaganda de loterias estrangeiras, assim como das estaduaes, fóra dos limites dos Estados que as houverem concedido - $200 \$ 000$ e apreensão. $\S 4 .^{\circ}$ Incorrerá em pena de exoneração o agente do poder público que aceitar por qualquer fórma favor ou retribuição de infratores ou condescender com a prática de qualquer jogo proíbido, sem prejuizo de outras sanções, que no caso couberem. $\S 50^{\circ}$ Considera-se jogo proíbido: a) a loteria de qualquer especie não autorizada por lei federal; b) qualquer operação ou aposta cujo desfecho ou solução depender de sorteio efetuado por loteria mesmo autorisada; c) as apostas sobre corridas de cavalos efetuados fóra dos respetivos prados. $\S 6 .^{\circ}$ Não se compreendem nas disposições do § anterior: a) o sorteio de apolices e outras obrigações da União, dos Estados e dos Municipios; b) os sorteios que realizarem as sociedades anônimas para simples resgate de ações ou debêntures, sempre que não haja bonificação de nenhuma especie; c) a venda de mercadorias ou imoveis, mediante sorteio, na fórma do respetivo regulamento, desde que não haja distribuição de dinheiro, nem conversão em dinheiro dos premios sorteados; d) os sorteios de apolices realizados pelas companhias de seguro de vida; e) as operações ditas de capitalisação, reguladas pelo poder competente, desde que nãa 
impliquem o sorteio de premios em dinheiro, nem a conversão em dinheiro dos titulos sorteados. 368: Pela contravenção denominada "jogo do bicho", praticada mediante a venda de cautelas, bilhetes, papeis avulsos, com ou sem dizeres, ou ainda sob quaesquer outras modalidades, incorrerão em penas: a) os empreendedores ou banqueiros do jogo; b) os que comprarem, distribuirem ou venderem os bilhetes ou papeis; c) os que direta ou indiretamente promoverem ou facilitarem o seu curso - 6 meses a 1 ano $e$ multa de 10 a 50:000\$000 para os empreendedores ou banqueiros; e 10 a 30 dias e multa de 200\$ a 1:000:000 aos demais infratores. Se os infratores forem estrangeiros, as penas serão acrescidas de expulsão do territorio nacional.

\section{Capítulo $\mathrm{X}$}

\section{Disposição comum}

Art. 387 - Não será punivel aquele que cometer crime previsto neste título, em prejuizo:

I - do cônjuge, na constancia da sociedade conjugal;

II — de ascendente ou descendente, seja o parentesco legítimo ou ilegítimo, civil ou natural;

III - de irmão, ou irmã, legítimo ou ilegítimo, civil ou natural, que cohabite com o agente.

$\S 1^{\circ}$ - Será punivel, mediante queixa, qualquer dos crimes previstos neste título, quando cometido em prejuizo:

I - do conjuge desquitado ou judicialmente separado;

II - de irmão, ou irmã, que não cohabite com o agente.

III - de tio, ou sobrinho, que com o agente cohabite.

$\S 20^{\circ}$ - Não se aplicarão as disposições deste artigo:

I - a quem cometer quelquer dos mencionados crimes com ameaça ou violencia á pessoa;

II - ao estranho que participar do crime.

Pr. $186 \S 4 .^{\circ}$ - Não é punivel o furto entre ascendentes e descendentes, seja o parentesco legítimo ou ilegítimo, civil ou natural, nem 
entre cônjuges, na constancia da sociedade conjugal, e entre colateraes até $04^{\circ}$ grau só o será mediante representação.

Cons. 335 - A ação criminal de furto não terá logar entre marido e mulher, salvo havendo separação judicial de pessôa e bens, ascendentes, descendentes e afins nos mesmos graus.

\section{Disposições finaes}

Art. 388 - E' creada em cada uma das sédes das Côrtes de Apelação uma Caixa Local de Reparações, que será administrada pelo respectivo Conselho Penitenciario.

$\S 10^{\circ}$ - Recolher-se-ão á Caixa :

I - as multas impostas como pena criminal;

II - as fianças ou cauções perdidas pelos condenados;

III - as reparações abandonadas por quem de direito;

IV - o produto da venda dos bens confiscados;

$\nabla$ - as multas impostas a jurados e peritos;

VI - a quota parte do salario do condenado, destinada á reparação do dano que de outra fórma não o tiver sido;

VII - a renda dos bens sequestrados ao condenado;

VIII - quaesquer contribuições voluntarias.

§ 2..$^{\circ}$ - Cada condenado terá na Caixa uma conta especial, em que se anotarão as aplicações do respectivo salario.

$\S 3 .^{\circ}$ - Os fundos da Caixa serão aplicados da seguinte maneira :

I - uma quarta parte, para adeantar ao ofendido ou sua familia, quando reduzidos á necessidade pelo crime, uma parcela da reparação devida pelo criminoso, ficando a Caixa subrogada no direito de rehaver deste ultimo o adeantamento, á custa de seus bens ou salario;

II - uma outra, para indenizar o injustamente condenado em ação intentada pelo Ministerio Público, uma vez que a sua inocencia tenha sido expressamente reconhecida no julgamento da revisão criminal ; e tambem o réo que, em ação da mesma natureza, haja sofrido 
prisão e tenha sido afinal absolvido ou não pronunciado, uma vez que a sentença de absolvição ou de não pronuncia, reconheça explicitamente a existencia de prejuizo notavel e 0 direito á indenização;

III - outra, para atender ás despesas do patronato de egressos das prisões e liberados condicionaes;

IV - a ultima, para subvencionar o patronato de menores.

§ 4. $.^{\circ}-E^{\prime}$ de aceitação obrigatoria e será desempenhada gratuitamente a função de membro do Conselho. Penitenciario.

Pr. Omisso.

Cons. Omissa.

Art. 389 - Fica revogada a Consolidação das Leis Penaes, aprovada e adotada pelo decr. n. 22.213, de 1932.

Art. 390 - Este Código entrará em vigor a $10^{\circ}$ de Janeiro de 1939.

S. Paulo, 11 de Agosto de 1938.

Alcantara Machado

GRATIAS DEO 